\author{
UNIVERSIDADE DE SÃO PAULO \\ Faculdade de Filosofia, Letras e Ciências Humanas \\ Departamento de Teoria Literária e Literatura Comparada \\ Programa de Pós-Graduação em Teoria Literária e Lit. Comparada
}

Ivan Delmanto Franklin de Matos

\title{
O LABIRINTO MIOPIA \\ O espetáculo teatral como planetário em ruínas
}

\begin{abstract}
Dissertação apresentada ao Programa de Pós-graduação do Departamento de Teoria Literária e Literatura Comparada da Faculdade de Filosofia, Letras e Ciências Humanas da Universidade de São Paulo, sob a orientação do Prof. Dr. Jorge Mattos Brito de Almeida, como parte do requisito para a obtenção do título de Mestre em Teoria Literária e Literatura Comparada.
\end{abstract}

São Paulo

2011 


\author{
UNIVERSIDADE DE SÃO PAULO \\ Faculdade de Filosofia, Letras e Ciências Humanas \\ Departamento de Teoria Literária e Literatura Comparada \\ Programa de Pós-Graduação em Teoria Literária e Lit. Comparada
}

Ivan Delmanto Franklin de Matos

\title{
O LABIRINTO MIOPIA
}

O espetáculo teatral como planetário em ruínas 
Nome: MATOS, Ivan Delmanto Franklin.

Título: O Labirinto Miopia: o espetáculo teatral como planetário em ruínas

Dissertação apresentada ao Programa de Pósgraduação do Departamento de Teoria Literária e Literatura Comparada da Faculdade de Filosofia, Letras e Ciências Humanas da Universidade de São Paulo, sob a orientação do Prof. Dr. Jorge Mattos Brito de Almeida, como parte do requisito para a obtenção do título de Mestre em Teoria Literária e Literatura Comparada.

Aprovada em: 22 de agosto de 2011

Banca Examinadora:

Prof. Dr. Jorge Mattos Brito de Almeida

Prof. Dr. Antonio Carlos de Araújo Silva

Prof. Dra. Maria Silvia Betti. 
MATOS, Ivan Delmanto Franklin. O Labirinto Miopia: o espetáculo teatral como planetário em ruínas. 2011. 276f. Dissertação (Mestrado em Teoria Literária e Literatura Comparada). Faculdade de Filosofia, Letras e Ciências Humanas. Departamento de Teoria Literária e Literatura comparada da Universidade de São Paulo, 2011.

Resumo: Esta dissertação, que tem como objeto o processo de criação do espetáculo teatral Miopia, investiga as tensas relações entre forma teatral, abordada em suas diversas e contraditórias dramaturgias, e o tecido histórico. Procuramos reler tal experiência estética questionando se é possível enxergar nas cicatrizes, limitações e contradições do espetáculo teatral e do seu processo de criação índices da realidade histórica, caracterizada pelo estágio tardio do sistema capitalista de produção. Para conceituar esta experiência artística, que representou algumas possibilidades de "suspensão dialética" (sacrifício, aniquilamento, conservação e superação) dos pressupostos do teatro épico sistematizados por Bertolt Brecht, criamos o conceito de "labirinto". Utilizamos este conceito porque categorizações geralmente utilizadas na descrição do teatro contemporâneo, como a de "teatro pós-dramático", também não se ajustavam ao objeto, já que este levantava questões ligadas à tentativa de configurar características próprias da formação social brasileira. Esta forma do labirinto é caracterizada em Miopia por uma utilização sistemática da alegoria de difícil decifração, entendida aqui em sua aproximação da ruína, do enigma e da incompletude. Apresentada em uma Usina de Compostagem de Lixo, a peça teve sua encenação construída por meio de detritos de formas e procedimentos teatrais tradicionais e a partir do lixo, expondo na própria cena o inacabamento de seu processo de criação. $\mathrm{O}$ fracasso das intenções iniciais presentes neste processo pôde ser revelado nesta dissertação como possibilidade de construção de sentido, em que a crise de compreensão em Miopia inseriu o público como criador e consumador do espetáculo teatral, dissolvendo o conceito de obra artística e substituindo-o pela ideia de um "ensaio em perpétuo devir".

Palavras-chave: 1) Teatro; 2) Dramaturgia; 3) Teoria Crítica; 4) Teatro Épico; 5)Teatro contemporâneo ; 6) Capitalismo; 7) Dialética 


\begin{abstract}
In this dissertation our object of study is the creative process of the theater performance Miopia. It investigates the tense relations between the theatrical forms, approached by its diverse and contradictory dramatic structures, and the historical weaving. We aim to review this aesthetical experience by questioning the possibility of finding indexes of the historical reality, characterized by the late capitalist production system, as we look into the scars, limitations and contradictions of the theater performance and its creative process. In order to conceptualize this artistic experience, that has presented some possibilities of "dialectical suspension" (sacrifice, annihilation, conservation and overcoming) from the Bertolt Brecht's epic theater presuppositions, we have come up with the concept of "labyrinth". We stick to this concept because the categorizations that are currently used to describe contemporary theater, as the "postdramatic" one, cannot fit in our object of study, as it has brought up questions that are connected to the attempt of configuring specific characteristics of the Brazilian social development. The labyrinth set-up is characterized in Miopia by a systematic use of the allegory of the hard deciphering, here understood by approaching the ideas of ruin, enigma and incompleteness. The performance took place in a Garbage Composting Plant, and the staging was set up from the debris of traditional theatrical forms and procedures and from garbage, exposing on stage the undone characteristic of its own creative process. The failure of the initial intentions of the process could be analyzed in this dissertation as a possibility of constructing meaning, in which the crises of understanding Miopia has brought the audience to the role of creator and consummator of the theatrical performance, dissolving the concept of "work of art" and replacing it by the idea of a "perpetual becoming rehearsal".
\end{abstract}

Keywords: 1) Theater; 2) Dramaturgy; 3) Critical Theory; 4) Epic Theater; 5) Contemporary Theater; 6) Capitalism; 7) Dialetic 


\section{Agradecimentos}

Ao Professor Jorge de Almeida, pelos colóquios precisos sobre crítica dialética, política e teatro. Pelas provocações e críticas agudas ao texto, que me conduziram dos caminhos dogmáticos à busca pelos labirintos das contradições.

À professora Maria Silva Betti, pela leitura atenta do exame de qualificação, pelas profundas aulas sobre o teatro épico na matéria do mestrado e pelo incentivo às minhas peregrinações diletantes em meio às peças de Vianinha. Agradeço também ao professor Fabio de Souza Andrade, pela participação no exame de qualificação e pelas críticas atenciosas formuladas sobre a precária primeira versão desta pesquisa apresentada naquele momento.

À Comissão de Pós-Graduação do Departamento de Teoria Literária e Literatura Comparada pela extensão do prazo limite de entrega deste trabalho, sem a qual não poderia ter avançado em questões fundamentais.

Aos funcionários do Departamento de Teoria Literária e Literatura Comparada da USP, especialmente ao Luiz Mattos, que sempre me ajudou na orientação e condução pelos labirintos de prazos e documentos da Universidade.

Aos meus pais, Dileta e Marco, pelas conversas filosóficas e literárias diárias, desde a infância, pelas críticas duras e também doces, pelo apoio integral e contínuo, constelação de múltiplos desenhos em um mundo em que as estrelas despencaram há muito.

Aos artistas que passaram pela II Trupe de Choque e também criaram Miopia, André, Elenira, Estefânia, Juliana, Margarida e Marko, pelas horas sem fim de parceria e labirinto. Ao Marcus, que também participou de Miopia e que não pôde conhecer esta dissertação, fica além do agradecimento sempre um tanto de saudade.

À II Trupe de Choque: Amanda, Anderson, Carmen, Cinthia, Edu, Eliseu, Fernanda, Jô, Leila, Lígia, Luzi, Marcelo, Marceleza, Maria, Murilo, Pablo, Ricardo, Sansorai e Valmir, pela paciência, amor e apoio nos momentos mais difíceis desta pesquisa e da criação em grupo, resistência sempre difícil e iluminada. Pelo convívio e pelas descobertas coletivas diárias, no infinito processo de investigação rumo a algo que não sabemos. 
Esta pesquisa contou com o importante apoio de uma bolsa de estudos da CNPq no período de outubro de 2008 a janeiro de 2010. 
$A$ dramaturgia de tipo $P$ [planetário], crítica, realista que à primeira vista parece deixar o espectador tanto mais liberado a si mesmo - na realidade o equipa melhor para atuar. Seu passo decisivo, a renúncia à empatia, só tem por objeto entregar o mundo ao homem, em lugar de entregar o homem ao mundo, como faz a dramaturgia de tipo $C$ [carrossel], de empatia, ficção e vivência.

Bertolt Brecht, Tipo C e Tipo P na dramaturgia

A tradição de todas as gerações passadas é como um pesadelo que comprime o cérebro dos vivos. E justamente quando parecem estar empenhados em transformar a si mesmos e as coisas, em criar algo nunca antes visto, (...) eles conjuram temerosamente a ajuda dos espíritos do passado, tomam emprestado os seus nomes, as suas palavras de ordem, o seu figurino, a fim de representar, com essa venerável roupagem tradicional e essa linguagem tomada de empréstimo, as novas cenas da história mundial.

Karl Marx, O 18 de brumário de Luís Bonaparte

Nada está menos sob o poder dos homens do que a sua língua.

Spinoza, Ética

A MARCA DE UMA MORDIDA em lugar algum.

Também a ela

Tens de combater,

A partir daqui.

Paul Celan 


\section{SUMÁRIO}

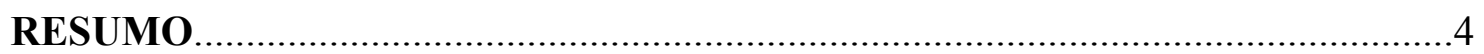

ABSTRACT

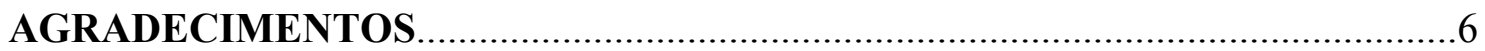

SUMÁRIO

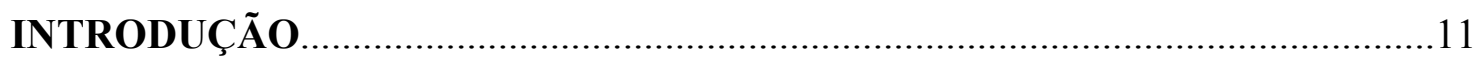

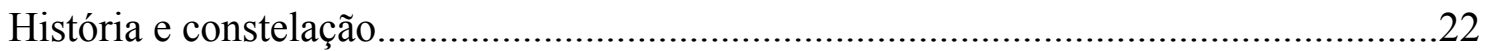

CAPÍTULO 1 - I. Saída interrompida 1: o percurso lixo/Primeira crise......................31

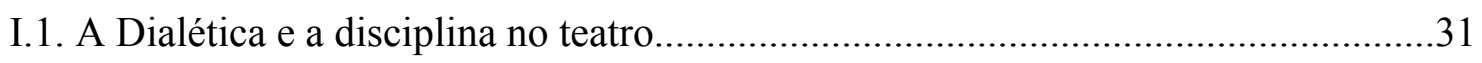

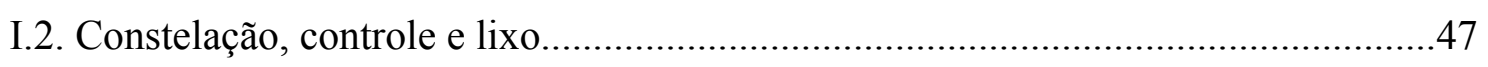

I.3. Tentativas de resposta: constelação em interpassividade...........................63

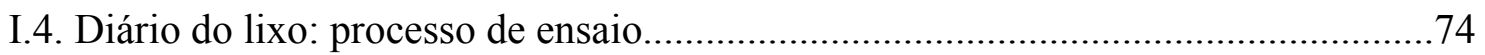

CAPÍTULO 2 - II. Saída interrompida 2: a dissolução da autoria no labirinto/Segunda crise

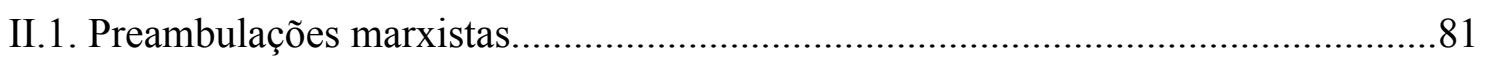

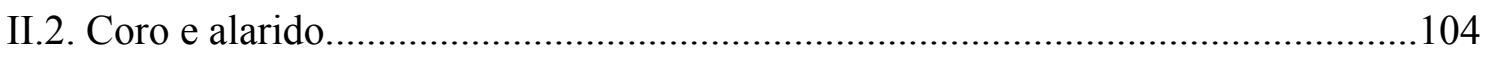

CAPÍTULO 3 - III. Saída interrompida 3: polifonia, dissonância e desmoronamento no labirinto/Terceira crise

III.1. Labirinto de vozes: Brecht, Stanislavski, Artaud e Beckett - início do desmoronamento. 120

III.2. Dramaturgia da iluminação em Miopia: mímesis soterrada?. .138

CAPÍTULO 4 - IV. Saída interrompida 4: lógica protestante, dialética, estranhamento e 
cinismo/Quarta crise.

.149

IV.1. Crise do teatro épico no Brasil e olhar petrificante: lógica protestante, dialética e estranhamento

IV. 2. Novo olhar melancólico: dialética brasileira no épico arruinado de

Miopia.

CAPÍTULO 5 - V. Saída interrompida 5: apagamento e memória em Miopia: forma labirinto como memória e usina de detritos/Quinta crise. 191

V.1. A forma labirinto e suas classes.

V.2. Dramaturgias do espaço em Miopia: a forma labirinto, o espetáculo da cidade e o espelho 209

V.3. As dramaturgias da memória e a experiência de Miopia. 227

CAPÍTULO 6 - VI. Saída interrompida 6: a Dialética no Teatro: na sala de espera do labirinto/A casa e a usina: a cena contra o texto/o labirinto contra o drama/sexta crise. .235

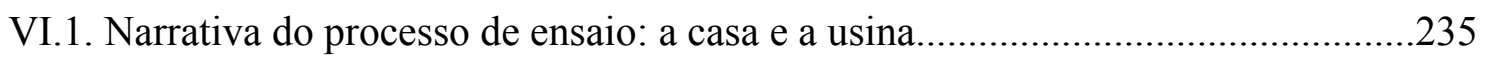

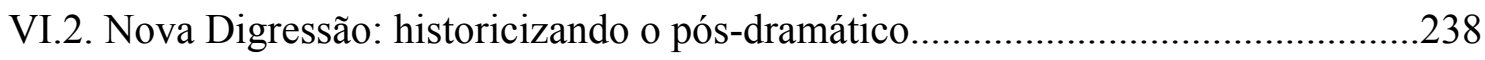

VI.3. O pós-dramático negado pelo labirinto: contradições produtivas. 253

CONCLUSÃO: O labirinto como constelação saturada de crises. .261

ANEXO - FICHA TÉCNICA DE MIOPIA .288

REFERÊNCIAS .293 


\section{Introdução}

Nesta dissertação, cujo objeto é a experiência de criação do espetáculo teatral Miopia, procuramos refletir sobre a tentativa, empreendida pelo coletivo teatral II Trupe de Choque, de dar forma aos movimentos informes do capitalismo tardio. ${ }^{1}$ Para além do resultado alcançado, o que importa a esta pesquisa é revelar o tatear às escuras, labiríntico, configurado nesta busca por suspensão (sacrifício, aniquilamento, conservação e superação ${ }^{2}$ ) dos pressupostos do teatro épico, em um percurso que fosse capaz de representar novos conteúdos históricos, em suas fraturas presentes no mundo contemporâneo.

A partir do relato desta experiência teatral que formou Miopia, processo em que trabalhei como encenador e dramaturgo, - espetáculo apresentado de abril a novembro de 2006 na Usina de Compostagem de Lixo de São Mateus (na periferia leste de São Paulo) pela companhia teatral II Trupe de Choque, - procuramos investigar aqui as tensas relações entre forma teatral, abordada em suas diversas e contraditórias dramaturgias, e tecido histórico. As inúmeras tentativas de saída, que constituíram um processo de criação em labirinto, questionam se os procedimentos formais, gerados por um processo de criação determinado, podem revelar, de forma mediatizada e no interior da obra, algumas das constelações em labirinto, saturadas de crises, que configuram a realidade histórica contemporânea. Além disso, procuramos reler tal experiência estética “a contrapelo", investigando principalmente nas cesuras e contradições do espetáculo e do seu processo de criação estes índices da realidade histórica caracterizada pelo estágio tardio do sistema capitalista de produção no Brasil. Tal investigação foi realizada a

\footnotetext{
${ }^{1}$ Partimos do conceito de Ernest Mandel, que define o capitalismo tardio como o atual terceiro estágio deste sistema, hegemonicamente batizado de globalização. Sucedendo os estágios do capitalismo de mercado e do monopolista ou imperialista, o capitalismo multinacional marca a apoteose do sistema e a expansão global da forma mercadoria, colonizando áreas tributárias de tal forma que não se pode mais falar de algum lugar "fora do sistema", como a Natureza ou o Inconsciente, constantemente bombardeado pela mídia e pela propaganda.

${ }^{2}$ O conceito de aufhebung,é em geral traduzido por "superação", quando não por "suprassunção", termo criado por Paulo Menezes ao traduzir a Fenomenologia do Espírito, na tentativa de reproduzir numa única palavra a junção entre abolir, elevar e conservar, presente em "aufhebung". Seguindo Leandro Konder, Jorge de Almeida e Gabriel Cohn, sempre que mencionarmos tal conceito adotaremos "suspender", com todas as suas variações.
} 
partir da consideração de fragmentos e de cenas da peça, bem como de relatos do processo de ensaio, testemunhados por vários dos seus participantes.

A II Trupe de Choque buscava, naquele momento de construção de Miopia, um teatro a partir do que Fredric Jameson chamou de "estética do mapeamento cognitivo" uma cultura política e pedagógica que buscasse dotar o sujeito individual de um sentido mais aguçado de seu lugar no sistema global - um teatro que, necessariamente, levasse em conta uma "dialética representacional" extremamente complexa, aparentemente enfeitiçada pelos imperativos categóricos da mercadoria e de suas ilusões, e inventasse formas radicalmente novas para lhe fazer justiça.

Tal teatro interessado em problematizar a realidade histórica presente não seria, então, uma convocação para a volta a um tipo mais antigo de aparelhagem, a um espaço nacional mais antigo e transparente, ou a qualquer enclave de uma perspectiva mimética mais tradicional e tranquilizadora. $\mathrm{O}$ grupo acreditava que esta nova arte política teria que se ater à verdade do capitalismo tardio, isto é, a seu objeto fundamental - o espaço mundial do capital internacional -, ao mesmo tempo que teria que realizar a façanha de chegar a uma nova modalidade de representá-lo, de tal modo que todos, artistas e público, pudessem começar novamente a entender seu posicionamento como sujeitos individuais e coletivos e recuperar sua capacidade de agir e lutar, que estaria neutralizada pela confusão espacial e social contemporânea.

No entanto, parece-nos que este breve relato da pesquisa e da construção de Miopia só nos servirá para percebermos de que forma os pressupostos deste processo de criação foram negados na realização da obra teatral, graças ao confronto com uma realidade histórica que não poderia ser plasmada por meio das formas artísticas investigadas inicialmente pelo grupo. A análise de Miopia, assim, não levou em conta as intenções dos criadores e nem procurou explicitar possíveis conteúdos presentes na obra, tentação que pode advir a uma investigação que também considera o processo de criação do espetáculo, como adverte Georg Lukács:

O defeito maior da crítica sociológica da arte consiste na sua busca e análise dos conteúdos das criações artísticas com o objetivo de estabelecer uma relação direta entre eles e determinadas condições econômicas. $\mathrm{O}$ verdadeiramente social na literatura é a forma. (...) É indiscutível que, na realidade, surjam muitas dificuldades, porque a forma jamais se converte em vivência consciente no sujeito receptor e mesmo no seu criador. ${ }^{3}$

\footnotetext{
${ }^{3}$ LUKÁCS, Georg. Reflexões sobre a sociologia da literatura. In: Georg Lukács: sociologia. São Paulo:
} 
Assim, ler o que permaneceu irrealizado no tecido formal do espetáculo, ler aquilo que o espetáculo reprimiu, significa tentar apreender o que foi criado graças a uma forma teatral que negou os objetivos iniciais dos seus criadores. Tal metodologia possibilita abrir lugar para a prática de uma negação dialética na contradição entre os termos realizados e os irrealizados, para uma reestruturação de uma relação de tensão entre a presença e a ausência.

Essa missão interpretativa procurou encontrar seu conteúdo privilegiado em falhas e descontinuidades dentro da obra. O objetivo deste método torna-se assim a explosão da obra aparentemente unificada em miríades de elementos conflitantes e contraditórios para que, posteriormente, essa multiplicidade possa ser reunificada, no nível de seu processo de produção, que não é aleatório, mas pode ser descrito, em si mesmo, como operação funcional coerente.

A metodologia empregada neste percurso parte de um pressuposto a ser testado: o de que a crítica teatral necessitaria de sua "Teoria Crítica". Os estudos teatrais, mesmo após Peter Szondi ter escrito o seu fundamental Teoria do Drama Moderno - em diálogo com a reflexão estética de Theodor Adorno e Georg Lukács -, ainda procuram a melhor forma de investigar possíveis relações, contraditórias e mediatizadas, entre a forma teatral, considerada como espessura de linguagens artísticas diversas, e seus subtextos histórico e social. Quando esta articulação entre forma e seus subtextos histórico e social são levados em conta, como no caso emblemático de Szondi, o objeto da análise crítica é apenas o texto teatral, encarado como literatura e isolado das outras expressões artísticas que fazem da obra teatral uma espessura de sentidos.

Para falar em forma, sem ignorar a complexidade do fenômeno teatral, partimos do princípio de que é preciso adotar um conceito ampliado de dramaturgia, ultrapassando o âmbito de uma investigação do texto teatral, para englobar as infinitas relações entre texto e cena, bem como a diversidade e polifonia dos diversos criadores dramatúrgicos do fenômeno teatral.

Seria possível considerar dramaturgo não só o escritor do texto teatral, mas também os atores, o diretor e os espectadores, traçando seus percursos e estabelecendo suas conquistas, limites, fissuras e aberturas, inserindo-os em um momento histórico específico. Ao longo da análise do processo de criação de Miopia, esta dissertação procurou ver a obra teatral como objeto caracterizado por essa polissemia de linguagens 
e por uma relação contraditória entre encenação e texto. Dramaturgias (em vez de dramaturgia) encaradas a partir das raízes etimológicas do termo: o dramaturgo como um construtor de ações, possibilitando compreender assim os múltiplos tecidos da criação teatral e dos seus diversos dramaturgos, sua espessura de linguagens, de signos e de sentidos que, para além do texto literário, da narrativa, do personagem e do diálogo, é caracterizada pela materialidade da ação. No entanto, o que importou a este trabalho foi abandonar a noção do espetáculo teatral como obra orgânica, de relação harmônica entre suas dramaturgias, procurando identificar no seu tecido as cicatrizes da forma e do tecido histórico contemporâneo.

Assim, seria possível considerar o espaço/cenário de uma usina de lixo abandonada tão fundamental para a construção das ações e de seu sentido dentro da obra teatral quanto às palavras ditas pelos atores. Como define o encenador Eugênio Barba:

O que me servia era a eficácia de uma forma de olhar que levava em conta lógicas diferentes e sobrepostas. Cada nível de organização, de fato, não é uma coisa que podemos ver separadamente em cima da mesa anatômica. É uma lógica, uma ação concreta do pensamento ou do olhar, um olhar parecido com o de quem lê uma partitura musical horizontalmente e verticalmente ao mesmo tempo. (...) Dramaturgia, nesse sentido, era a criação de uma complexa rede de fios no lugar de simples relações. ${ }^{4}$

O espetáculo teatral poderia, assim, ser apreendido como mônada enclausurada no interior da forma, ao mesmo tempo gerada pela história e geradora de uma nova realidade, a estética, constelação ficcional gerida por suas leis próprias, ausente de janelas, mas aberta para o mundo. As leis próprias da forma artística teatral estariam naquilo que Eugênio Barba chamou, referindo-se às diversas expressões artísticas que configuram a obra teatral, de "uma propensão própria a desencadear com total liberdade um processo de associações e a misturar, de forma consciente ou acidental, componentes preestabelecidos para desconfigurá-los".

Essa noção ampliada de dramaturgia não é recente na história do teatro. Como Eugênio Barba, Antonin Artaud, Bertolt Brecht e também Jerzy Grotowski já interrogaram o fenômeno teatral a partir do esfacelamento das noções de ação, texto e dramaturgia. O conceito clássico de dramaturgia, embora a defina como "composição de ações" (e ação pressuponha personagens que ajam), restringia o âmbito dessa

\footnotetext{
${ }^{4}$ BARBA, Eugênio. Queimar a casa: origens de um diretor. São Paulo: Perspectiva, 2010, p. 40-41.
} 
composição ao de uma construção poética, de cunho literário. De maneira contrária a essa posição, Barba, por exemplo, afirma que "todas as relações, todas as interações entre os personagens ou entre os personagens e as luzes, os sons e os espaços, são ações. Tudo o que trabalha diretamente com a atenção do espectador em sua compreensão, suas emoções, sua cinestesia, é uma ação"5. Ao ampliar o conceito de ação, o teatro ao longo do século XX necessariamente expande o sentido não só de dramaturgia, mas também de texto, uma vez que, para tal relação entre texto e cena, as ações só "são operantes quando estão em trabalho, entrelaçadas, quando se tornam textura, tecido: a palavra 'texto', antes de se referir a um texto escrito ou falado, impresso ou manuscrito, significa 'tecendo junto'. Nesse sentido, não há representação que não tenha texto." 6

No programa de Miopia, encontramos a seguinte sinopse da peça:

No final do ano de 1930, o governo de Vargas organiza um grande comício em uma praça de São Paulo, chamada de Praça dos Desempregados, por ser local em que anúncios de emprego eram habitualmente expostos. Uma grande cantora do rádio foi convidada para apresentar o evento, Diotima Hansen, e a famosa dançarina Escrava Zuzu era a principal estrela do espetáculo. Em meio à apresentação de Zuzu, a polícia cerca a praça e os desempregados são conduzidos para um enorme caminhão, onde são trancafiados. Entre estes desempregados, encontram-se Rosa Medeiros, jornalista e liderança do Partido Comunista do Brasil, Belmiro Ilicht, operário militante, marido de Rosa, e Fausto Falstaff, carroceiro e admirador de Vargas.

A viagem é longa e os desempregados suspeitam que são parte de um plano do governo de higienizar a cidade da miséria, algo comum na política social getulista. Rosa e Belmiro tentam, sem sucesso, organizar os presos. Fausto, após assassinar um mendigo, começa a impor sua liderança através do terror e da força. Rosa decide aliar-se a ele, contra a vontade de Belmiro, que em seus delírios pensa liderar as massas oprimidas rumo à revolução.

As portas da carroceria do caminhão são abertas em meio a um local deserto, no Mato Grosso, onde os desempregados são abandonados. Eles vagam por dias em busca de um povoado. Fausto tem uma visão e prevê o caminho que devem seguir para encontrar boa sorte. Todos o seguem. Acabam encontrando um circo mambembe, o Circo dos Autômatos, em que o turco Fuad Chucro apresenta o famoso Autômato Turco, boneco com vida, que prevê o horror como destino dos desempregados. Rosa é hipnotizada e, sob o fascínio de todos, confessa ter como sonho transformar-se no Homem do Saco, para ser capaz de carregar

${ }^{5}$ BARBA, E.; SAVARESE, N. A arte secreta do ator: dicionário de antropologia teatral. São Paulo, Campinas: Hucitec, 1995, p. 69.

${ }^{6}$ Id., ibid. 
consigo todas as mercadorias que desejar. Um filme é exibido num cinematógrafo do Circo, hipnotizando os desempregados.

A convite do Turco Fuad, que viria a falecer dois anos depois, os desempregados formam uma cooperativa e passam a administrar coletivamente o Circo. Depois de dois anos, decidem empregar os lucros angariados na construção de uma cidade: espaço de utopia e de justiça, capaz de fazê-los esquecer da miséria. Para abrigar a cidade, decidem invadir terras desocupadas.

$\mathrm{Na}$ hora de dividir os lotes, a liderança apresenta duas propostas. Rosa sugere que o critério de distribuição deve ser a solidariedade: as famílias mais necessitadas seriam contempladas com os melhores lotes. Fausto sugere que organizem uma grande corrida: os mais fortes e competentes seriam os que escolheriam as melhores terras. A proposta de Fausto é vitoriosa e uma corrida sangrenta inaugura a cidade dos sonhos. Belmiro, que após a morte do turco Fuad, tornara-se o guardião do patrono e guia dos desempregados, o Autômato Turco, não participa da corrida e, no final, compra, com as economias do autômato, dois lotes para si.

A cidade é inaugurada e batizada de Miopia: a cidade capaz de curar a cegueira do país. Fausto torna-se o primeiro prefeito eleito e logo suas medidas fascistas o afastam de Belmiro e de Rosa, que fundam uma sessão do Partido Comunista na nova cidade.

Belmiro torna-se um construtor de autômatos e passa a exportar seus produtos para outras cidades e países. Alia-se, com a colaboração de Fausto que se apaixonara pelo cinematógrafo do circo, a Mr. Mackee, um investidor norte-americano, para a construção de um cinema de comerciais em Miopia. Mackee é gerente de uma empresa recolhedora de lixo em Massachussets e se habilita a exportar para Miopia filmes descartados de propagandas de empresas norte-americanas. Uma arquiteta de São Paulo é contratada para fazer o projeto do cinema.

A arquiteta, Mércia Alberico, chega misteriosamente na cidade, trazendo os dois filhos, Maribel e Antenor, presos em caixas de abelha. Ela constrói sua casa em cima do cemitério e vive cercada de boatos: Mércia seria uma feiticeira, encantadora de abelhas. Há também quem pense que ela é Olga Benário Prestes, fugitiva da polícia de Vargas. Seus filhos vagam pelas ruas da cidade vendendo mel e formando um quadro estranho: Antenor, o retardado mental, e Maribel, a feia menina de corpo torto. Os dois vendem mel no comitê do Partido Comunista, onde Maribel assina a sua filiação em troca de dinheiro. Em visita ao campo de obras do cinema, Mércia percebe que o seu projeto não é entendido pelos trabalhadores, que vagam pelo canteiro como fantasmas, sem encontrar sequer a saída daquele labirinto.

O cinema é inaugurado com um grande show da cantora Diotima Hansen, trazida de São Paulo. O cinema traz mudanças ao cotidiano dos habitantes de Miopia: os filmes de propaganda tornam-se a linguagem da cidade, cada vez mais habitada por mercadorias e por suas imagens encantatórias. A violência cresce, executada por aqueles que não têm acesso aos bens de consumo. $\mathrm{O}$ prefeito Fausto constrói o Pátio das Torturas e contrata Antenor para ser o seu carrasco.

Um movimento de contestação passa a ser organizado: a Greve do Olhar. Enquanto cola cartazes da greve na vitrine da loja de 
bonecos de Belmiro, Rosa encontra Maribel, que participa de outro movimento coletivo, colando cartazes junto de militantes do exército da Salvação: é a campanha "A Zuzu é nossa", cuja principal reinvidicação é que Belmiro construa réplicas perfeitas da famosa dançarina.

Diotima, que depois de fazer um show local não conseguira mais dinheiro para sair da cidade, torna-se uma prostituta, graças às lições do sábio Cego Keuner, filósofo da cidade, que a qualifica para vender o próprio corpo. É estuprada e torturada por Antenor. Com a ascensão das novas autômatas de Belmiro, prostitutas com o rosto das estrelas dos comerciais, Diotima torna-se um produto descartável, um pária, e assume uma outra personalidade, a do mendigo Johansen.

Belmiro, agora presidente da Sociedade dos Amigos do Cinema, organiza uma grande festa para comemorar o aniversário do cinema. Maribel Lee, que se tornara atriz do teatro de revista, faz um show de strip-tease para os operários do cinema. Belmiro mostra a Mércia as pesadas máquinas que, gravando com agulhas desenhos nas costas dos trabalhadores, produzem imagens. Mércia abandona a festa.

Rosa e Belmiro após tentarem, em vão, excitar-se fingindo ser as estrelas de propaganda do cinema, têm uma séria discussão: Rosa acusa Belmiro de ser um empresário ganancioso e atira no chão o Autômato Turco. Belmiro rasga a sua carteira de filiação ao Partido Comunista e a carteira do boneco: o casal rompe.

A Greve do Olhar toma as ruas, as pessoas tapam os olhos para não verem mais as propagandas. Fausto, dono da recém-inaugurada Fausto Filmes, quer exibir seus filmes artísticos no cinema. Começa a produzir um documentário combatendo Belmiro, a Sociedade dos Amigos do Cinema e os filmes de propaganda. Fausto manda a polícia soltar os grevistas do olhar e declara que a prefeitura considera a greve legal. Utilizando o apoio dos grevistas, fecha o cinema e abre uma nova licitação para empresas nacionais interessadas em exibir filmes "de verdade" no cinema. A Fausto Filmes é a única empresa a se inscrever.

Com o cinema fechado, uma peste assola a cidade. A Peste das Imagens ou a Peste Imaginária. Sem as propagandas, os cidadãos míopes imaginam que estão perdendo as próprias imagens, esvaziando-se e tornando-se bonecos. Belmiro percebe que pode lucrar com o surto coletivo e passa a vender máscaras anti-peste e diversos produtos "delivery".

Maribel decide fugir para o Rio de Janeiro para participar de um concurso: "Seja você a Nova Escrava Zuzu". Rouba as economias de Antenor e foge.

Johansen, sempre desprezado e humilhado, sabe da existência de um único filme que não foi queimado por Fausto. Um filme que mostra os excrementos do prefeito. Todos acreditam que se o cinema voltar a funcionar, a cidade estará salva. Johansen percebe que pode salvar a cidade que o humilhou e o destruiu: é sua forma de vingança. Johansen rouba o filme de Fausto e invade o cinema, para exibi-lo. Dezenas de pessoas aglomeram-se para ver o filme ser projetado, fascinadas com o retorno do encanto das imagens.

Após dois anos, Maribel retorna a Miopia e encontra uma nova paisagem: Belmiro tornara-se o prefeito, portador de novos 
paradigmas liberais e modernizantes, Rosa vende o seu best-seller sobre sua vida de militante, uma linha de produtos fecais faz enorme sucesso em todos os ramos de comércio e Fausto filma um documentário sobre a morte no quintal da casa de Mércia, agora um cemitério abandonado. Fausto reconhece Maribel como a exEscrava Zuzu e lhe oferece uma oportunidade de vencer: estrelando o seu filme sobre a morte de uma estrela de sucesso. Maribel aceita. Mércia, acabada e bêbada, participa da invasão de um grupo de Sem-Teto ao prédio do antigo cinema, interditado porque seria demolido, para a construção de um shopping center. Fausto, como parte do documentário sobre a morte, filma a invasão e, ao lado de Belmiro, pede que os Sem-Teto abandonem o prédio para que a prefeitura inicie a demolição. Os Sem-Teto abandonam o prédio. Mércia, no entanto, mesmo após os pedidos de Maribel, é enterrada viva sob os escombros do cinema.

No final, o público se depara com uma vitrine de bonecos: são os narradores da peça, Rosa, Mércia, Antenor, Johansen, Fausto e Maribel, vendidos pela empresa de Belmiro?

A longa sinopse vale ser citada na íntegra por dois motivos: primeiro, por revelar a construção narrativa empreendida pelo grupo, que pode ser na sinopse identificada em sua crueza, marcada por inúmeros movimentos, idas e vindas. Segundo motivo, consequência do primeiro, diz respeito ao fato do grupo optar por incluir no programa do espetáculo uma sinopse tão detalhada, como se o espetáculo a ser apresentado utilizasse um idioma diferente, que necessitasse de tradução. Esta desconfiança em relação à clareza da narrativa que iria ser contada ao público manifesta que os autores tinham consciência, em alguma medida, de que a encenação já não trilhava os mesmos caminhos do texto. Essa contradição entre texto e cena significou o fracasso dos objetivos iniciais sistematizados pelo grupo no início de sua pesquisa. Foi possível ler nesses fracassos possibilidades de construção de sentido, em que a crise de compreensão em Miopia, nesta dissertação representada pela alegoria do labirinto, inseriu o público como criador e consumador do espetáculo teatral, dissolvendo o conceito de obra artística e substituindo-o pela ideia de um ensaio em perpétuo devir.

Por fim, é importante mencionar o romance fundamental de Peter Weiss que inspirou a escrita desta dissertação, tanto em seu aspecto formal, metamorfose constante de ensaio e memória, quanto na identificação de muitas das questões artísticas abordadas no processo de criação de Miopia e que são também motivo de debate entre os personagens da ficção de Weiss. A estética da resistência tem sua narrativa situada entre 1937 e 1945, ainda que sua redação represente muitos dos compromissos políticos

\footnotetext{
${ }^{7}$ ALMEIDA, Ligia Marina, FARIA, Fernanda, DELMANTO, Ivan, et al. Miopia - Programa do espetáculo. Inédito, 2006, p.3.
} 
do autor nas décadas de 1960 e 1970. O contexto da guerra fria, da guerra do Vietnam e da incipiente decepção com a socialdemocracia sueca filtra-se no romance. Em suas páginas se narra a peripécia de personagens através dos quais (em suas preocupações e em suas convicções, em suas ações e em suas omissões) se desenvolve em panorama a história de todo o movimento operário no século XX e da inconclusa aspiração a uma vida não danificada (uma "sociedade livre de homens livres"). Este movimento ficcional, lembrando constantemente a Comuna e a Revolução de Outubro, relata os enfrentamentos entre socialdemocratas, fascistas e comunistas, representando as distintas perspectivas que adotam ante a revolução, as lutas e alianças de classe e a guerra. Durante os anos em que transcorre a narrativa, o protagonista transita da Alemanha nazista à frente republicana na guerra civil espanhola, para mais tarde terminar no exílio. A Suécia será ainda o refúgio do personagem principal e narrador, mesmo país em que o escritor também viverá até sua morte. Esse protagonista da obra (espécie de alter ego do próprio Weiss), pergunta-se em uma ocasião: "se pudéssemos chegar a captar algo da realidade política em que vivíamos, como se poderia plasmar esse material diluído e escasso... em uma imagem escrita com a aspiração da continuidade?".

Tal pergunta norteou o processo criativo de Miopia, que a todo instante travou embate com a herança do teatro épico. Curiosamente, para falar da importância do trabalho de pesquisa, de reunião documental e acumulação de dados históricos para o fazer literário, Peter Weiss relata no último volume do livro a estadia de Bertolt Brecht exilado na Suécia, em um episódio que termina com o protagonista ajudando a empacotar a biblioteca do famoso dramaturgo antes de sua partida aos Estados Unidos. O mesmo grupo de mulheres comunistas que haviam acolhido Brecht em sua fuga do nazismo é apresentado na narrativa como um exército de pacientes e laboriosas colaboradoras. São elas que propiciam ao dramaturgo os materiais históricos para montar Mãe Coragem e seus filhos (1939-1949). A devoção por esse trabalho de historicização artística que compartilham Bertolt Brecht e Peter Weiss aparece, não obstante, gestada de modo diferente no processo de criação de cada um deles. Peter Weiss repetirá sempre a investigação isolada, como a de um pintor em seu estúdio, sem ajuda de nenhuma equipe. Pelo contrário, Bertolt Brecht é apresentado na Estética da Resistência utilizando conscientemente um trabalho coletivo que lhe permite sintetizar os dados e diversos pontos de vista da realidade histórica. Veremos que esse tema da pesquisa histórica, tentando responder a essa "aspiração de continuidade", capaz de dar 
totalidade ao fragmentário, foi perseguido durante a criação de Miopia de maneira coletivizada, já que muitos dos parâmetros de Brecht foram pontos de partida para o trabalho. A transformação desta reunião de dados históricos, que visavam retratar de forma transparente o presente, em um labirinto é a contradição que fundamentou esta dissertação. Se tal labirinto pode ser relacionado a um dos objetivos iniciais de seus criadores - à formulação de uma estética teatral de resistência -, ou se Miopia é apenas mímesis de um processo histórico de produção acelerada de ruínas é uma das perguntas que procuramos fixar na constelação de tensões que nos guiaram e nos desviaram durante a pesquisa. A resposta está ligada, durante o desenvolvimento de nossa reflexão, ao estatuto do sofrimento e da agonia na estética teatral, aspectos que, ao serem potencializados, geraram no processo de criação descrito aqui diversas manifestações da ruína e do lixo.

Com um panorama de dilaceramento como esse, começa o primeiro livro da Estética da resistência. Sem dizer, em nenhum instante, do que se trata a descrição, procurando fazer com que seja o leitor quem faça o esforço de decifrá-la, diz Peter Weiss:

\begin{abstract}
Em volta, ao redor de nós elevam-se os corpos feitos de pedra, juntos aglomerados em grupos, entrelaçados ou quebrados em fragmentos, com um tórax, um braço amputado, um quadril rachado, um retalhado pedaço em sua forma insinuada, sempre nos gestos de luta, desviando, voltando rápido, golpeando, se protegendo, esticado para cima ou encurvado, aqui e ali apagado, porém ainda com um pé erguido e resistente, uma coluna dorsal contorcida, o contorno de uma panturrilha esticada em um único movimento comum. Um enorme combate, surgido da parede cinzenta, reportando ao seu acabamento, caindo sem forma. Estas faces então talhadas, novamente se apagando, estas mãos potentes e despedaçadas, estas amplas revigoradas narinas se afogando em rocha apática, este olhar de pedra, estes lábios estendidos num grito, estas pisadas e batidas, estes golpes de pesadas armas, estas polias de rodas blindadas, estes feixes de fulminados raios, estas pisadelas, este rebelar-se contra e romper-juntos, este infindo esforço, se arrastando acima dos granulados blocos. ${ }^{8}$
\end{abstract}

O friso desse altar de mármore criado entre 164 e 156 a.C. mostra uma gigantomaquia em que os filhos de Gea lutam contra os deuses de maneira sangrenta. São mais de cem figuras em desigual combate. Tanto os deuses como os gigantes estão representados em um momento de dilaceramento físico, e sobretudo nos vencidos se percebe extremo sofrimento. Esta anatomia da dor é observada por Coppi e Heilmann,

\footnotetext{
${ }^{8}$ WEISS, Peter. La estética de la resistencia. Barcelona: Hiru, 2006, p. 30
} 
os jovens operários protagonistas do relato que contemplam deslumbrados a obra e advertem rapidamente:

como os iniciados, os especialistas, falavam de arte, ensinavam a harmonia, a íntima compenetração dos gestos, e eles, que nem sequer conheciam o conceito de cultura, cravavam a vista furtivamente nas faces abertas e sentiam o golpe da garra na própria carne.

Peter Weiss rebate, em certa medida, os postulados estéticos sobre a função da arte do Esclarecimento, porque, ao contrário de Lessing ou Winckelmann, insiste em que a arte - ainda que não pretenda - sempre mostra aspectos do sofrimento do ser humano e não há por que evitá-lo, disfarçá-lo nem dissimulá-lo. E quando no começo dos anos trinta se anuncia o enfrentamento decisivo entre as forças democráticas e populares com o fascismo, a mera reflexão sobre o friso do Altar de Pérgamo anuncia por um lado o inevitável da luta, mas desgraçadamente também seu resultado. Urano, os Gigantes, os Titãs ou os Ciclopes nada poderiam contra Zeus, Tritão ou o mercenário Heracles.

Em uma digressão que se acumula a essa cena inicial, o afã didático de Peter Weiss o leva a contrapor $A$ greve (1886) de Robert Koehler a um quadro de Adolph Menzel, A laminadora ou os ciclopes modernos (1875). Se no primeiro quadro os trabalhadores estão organizados para abandonar a fábrica e comunicar suas demandas a um senhor de cartola, "o explorador", no segundo, os trabalhadores fundem seus corpos com o calor da máquina. Mostram-se, como escreveu Peter Weiss, "relegados à produção de mercadorias". A diferença entre as obras, ainda que estejamos falando de pinturas do século XIX, encontra-se no descobrimento do trabalho imaterial como lugar de uma nova produtividade social ${ }^{9}$. Em sua análise, Weiss dialoga com o que se apregoava na Itália do final dos anos sessenta, quando se declarou o fim da fábrica clássica. Essas mutações do sistema capitalista de produção são tratadas nesta dissertação em processo semelhante ao que empreende Weiss ao realizar sua comparação entre os dois quadros: o processo de criação de Miopia partiu dos modelos artísticos gerados para tratar de uma constelação histórica retratada por Koehler, mas,

\footnotetext{
${ }^{9}$ Em meados dessa década Peter Weiss já antecipara essas ideias em uma entrevista que Alfonso Sastre publicou quando faleceu o escritor, em que este último se lamentava amargamente: "Ah, Suécia, Suécia... Este país é um exemplo do pouco que pode conseguir a socialdemocracia: baixos salários..., injustiças tão grandes como em qualquer país capitalista... Claro que há um mais alto nível de vida, não há verdadeira miséria..., ninguém morre de fome, é certo..., automóveis..., mas um ritmo de trabalho tão inumano... que os trabalhadores não têm tempo para pensar..." (WEISS, Peter. Op.cit., p. 1112).
} 
precisamente no fracasso desta intenção reside o surgimento da forma labiríntica da peça, que pode ser compreendida em relação ao surgimento de novas formas de dominação, de hegemonia e de produção de valor, marcas do tempo presente.

Os operários, personagens protagonistas da Estética, não adotam a atitude tão comum de conferir a um quadro seu valor estético pela coincidência do representado com a realidade. Para esses trabalhadores a beleza de um quadro não reside realmente no seu assunto. Weiss se pergunta "como se pode considerar bela a representação do sofrimento?" A resposta afirma que se trata de entender a arte como testemunha da história, testemunha, entretanto, que não necessita apresentar as coisas como se fossem verdade, mas sim ser capaz de organizar distintos pontos de vista em uma totalidade de contradições.

O denominador comum na análise de Peter Weiss sobre a função da arte é a dialética entre a suspensão e a ativação da dor, sintetizando a História como quadro petrificado de derrotas. Esse processo de agonia contínua é tratado em Miopia a partir de um olhar que petrifica as vítimas do processo de produção/destruição do capitalismo tardio, tratadas como mercadorias descartáveis, sob o cadáver das formas do teatro épico do século XX.

\section{História e constelação}

Em carta escrita ao amigo Florens Christian Rang, em 20 de janeiro de 1924, Walter Benjamin pede ajuda para o traçado de uma possível relação entre a tragédia grega e o ágon, ancestrais rituais de morte sacrificial. A resposta de Rang, de 28 de janeiro de 1924, ensaia um caminho:

Formulando a questão à imagem da corrida: o deus de salvação a que se chega fecha um ato, mas não é a estação final da alma que corre, é um destino de graça contingente, mas não a certeza, não a paz total, não o evangelho absoluto; também sob o seu reino podem emergir de novo a ira, a exigência de vítimas, a fuga da alma diante do destino superior. Daí, a tri ou tetralogia antiga, que apresenta fases da corrida libertadora, (...) não na ordem estabelecida, mas na sua dissolução (...), de tal modo que agora o êxtase pode irromper do medo, a palavra livre (dictamen) exceder a lei, o novo deus (Dioniso) superar os antigos. ${ }^{10}$

No ágon a vítima pode fugir se for suficientemente rápida. Para Benjamin,

10 BENJAMIN, WALTER. The correspondance of Walter Benjamin, 1910-1940. Chicago: Chicago University,1994, p. 231-234 
seguindo as pistas de Rang, o teatro trágico de Atenas estaria próximo à noção de ágon. E trata-se de um ágon em que, no julgamento do deus, se apela a um deus-salvador superior. O diálogo é um desafio por palavras, uma disputa. Tanto das duas vozes que acusam e defendem, quer o homem, quer o deus, como das de ambos, com vista ao objetivo comum, em direção ao qual correm.

A corrida agônica aconteceria também no teatro: como em um tribunal, divide ao meio o anfiteatro do embate, que pode durar o tempo que se quiser, e define os limites espaciais da cena. Da porta da desgraça, à esquerda, saem os "agonistas". Atravessam, passando pelo coro, o semicírculo da comunidade, contornam o altar dos sacrifícios e terminam o seu percurso na porta da salvação, à direita. A comunidade reconhece a vítima, a morte, mas decreta ao mesmo tempo a vitória, para os homens e para os deuses. A vitória na tragédia é aniquilamento ${ }^{11}$.

O semicírculo teatral concede saídas ao encontro desse aniquilamento. A tragédia grega retrata a corrida de morte e de vida do homem destinado a ser sacrificado, uma luta entre aquele que foge e seus perseguidores, entre valores há muito estabelecidos e a razão de Estado imperialista, que transformava a nação escravocrata grega em palco de contradições nunca antes vividas. Aquele que chega ao altar no centro da cena não é de fato sacrificado, mas a sua vida passa a pertencer ao deus, entra em prisão perpétua; aquele que foge - no semicírculo do teatro - é um homem livre. Esse é, para Benjamin, o sentido do ágon grego: "a consciência da vitória da humanidade contra a fossilização hierática."

Tal vitória se dá na esfera do processo penal antigo, todo ele diálogo, porque

\footnotetext{
11 O sentido original da palavra grega ágon está ligado ao ritual de disputa e competição presente em diversas manifestações culturais da Grécia Antiga, desde os jogos esportivos até a guerra. Na opinião de R. Lonis (em Guerra e religião na época grega clássica), na noção de ágon predominam duas ideias fundamentais: por um lado, a rivalidade e o combate entre dois adversários no qual o resultado normal é a vitória do mais forte ou do mais hábil, e por outro, as regras, as normas que os competidores devem respeitar. Autores como Gabaldón Martínez (Rituales de armas y de victoria: lugares de culto y armamento en el mundo griego), apontam a semelhança entre os rituais agônicos e a organização dos exércitos nas guerras gregas: o combate entre falanges estava submetido a regras que tinham aspectos lúdicos: era um ágon, ao mesmo tempo concurso e combate, prova e jogo. Convenções entre os adversários, eleição de um campo fechado, ereção de um troféu; tais eram algumas das regras essenciais do jogo da guerra. De fato, muitos combates rituais entre duas cidades vizinhas celebrados nos santuários podiam chegar a converter-se em autênticos enfrentamentos desenvolvidos em um campo de batalha.

A tradução empregada neste trabalho, que por vezes substitui este sentido mais usual de disputa pelo de "corrida", remete às encenações de alguns dos rituais ágon, em que se acompanhava a fuga da vítima a ser sacrificada pelo espaço circular definido para o ritual. Para Carrie L. Asman (em Theater and Agon/Agon and Theater: Walter Benjamin and Florens Christian Rang), este ritual de fuga, morte e de mutilação foi substituído, no nascimento da tragédia, pela disputa por meio de palavras (diálogos) e pela representação.
} 
assentado nos papéis contraditórios do acusador e do réu. O processo tem o seu coro próprio, formado em parte pelos jurados (no antigo direito cretense, segundo Rang, as partes enfrentavam a prova com "apoiantes do juramento", isto é, com testemunhas abonatórias que, a princípio ainda com armas para a luta, garantiam a lealdade e a razão da parte que defendiam), em parte pelo apelo público dos companheiros do acusado, que pediam compaixão ao tribunal (veja-se a Apologia de Sócrates, de Platão), e finalmente também pela assembleia popular que dita o veredito. No direito da Ática, e na forma da tragédia que o expressa, o importante e o característico é a irrupção do dionisíaco, ou o triunfo do extraordinário sobre a ordem. De acordo com Benjamin:

Acontece então que a palavra do transe, extática, pode quebrar o círculo normal do ágon, que a humanidade oprimida pelas formas (mas muitas vezes também em formas quase tão desumanas) pode extravasar de modo incontrolado, que um direito superior pode nascer da força de convicção da palavra viva, como no processo os clãs em disputa, com as armas ou com fórmulas linguísticas em verso. Neste caso, o ordálio é quebrado, em liberdade, pelo logos. Esta parece-me ser a mais profunda afinidade entre o processo jurídico e o teatro dramático em Atenas. ${ }^{12}$

A imagem da corrida agônica pelo semicírculo da cena interessa a este trabalho por acreditarmos estarmos diante de uma crise das formas teatrais consagradas pela modernidade, em uma agonia de procedimentos artísticos e de metodologias de criação capaz de assombrar determinados processos criativos teatrais preocupados em historicizar os tempos do capitalismo tardio. A corrida não pode, assim parece, dar-se mais no espaço semicircular da comunidade. As saídas não estão mais pré-definidas, assim como também não está mais assegurada a vitória da humanidade.

O processo compartilhado de criação ressurge com intensidade na cena teatral paulistana dos anos 90 e, ao valorizar a multiplicidade de artistas diversos que podem formar o fenômeno teatral, tenta superar a agonia de encenações antes centradas na única figura do encenador. Esse processo baseia-se no círculo: procura dividir o ágon em uma corrida de revezamento em que a polifonia dos distintos autores envolvidos procura fazer avançar o processo, procurando realizar a passagem harmoniosa do bastão.

Veremos que a particularidade do processo de criação a ser descrito nesta dissertação é exatamente a quebra da harmonia e da linearidade do círculo. Tal processo foi movido por contradições constantes e os procedimentos empregados possibilitaram a

\footnotetext{
${ }^{12}$ BENJAMIN, Walter, op.cit., p. 234.
} 
emergência de um coletivo em constante oposição, esfacelamento e recomposição, em um distanciamento da noção de coletividade transparente que muitas vezes foi hegemônica nas reflexões sobre os grupos teatrais paulistanos a partir dos anos 90. Essa crença absoluta no coletivismo baseava-se no pressuposto, questionável, de que o individualismo dos grandes encenadores ou dos grande atores deveria ser contraposto por uma criação coletiva que, pelo simples fato de coletivizada, seria responsável por novos modos artísticos de produção.

Na roda torta, tortuosa de Miopia, o círculo não se fechava, os atores e demais criadores perdiam-se na angústia da corrida, da reflexão e da crítica sobre o que está sendo produzido, improvisação a improvisação, morte a morte. Não há mais comunidade, experiência, nação, espaços transparentes de reconhecimento entre o sujeito, a humanidade e as estrelas, que eram capazes de dar orientação. As constelações desenham labirintos. Brecht chegou a comparar o seu teatro épico a um planetário:

O planetário mostra os movimentos das estrelas, na medida que os
conhecemos. (...) Ainda que a regularidade dos movimentos das
estrelas no planetário não nos pareça humana, tampouco pode-se
dizer que nos pareça estelar. Este engenhoso aparato tem um
defeito mais: seu esquematismo. Seus perfeitos círculos e elipses só
reproduzem imperfeitamente os verdadeiros movimentos, já que
estes são mais irregulares. Nossa dramaturgia não deve reproduzir
os movimentos do homem como se se tratasse de movimentos
mecânicos (...), devemos sublinhar exatamente este caráter sumário
e limitado de nossos testemunhos mostrando o caso individual de
que se ocupa nossa dramaturgia, precisamente como um caso
individual, e mostrando uma e outra vez seus desvios da norma.(...)
Por renovadores que pretendamos ser em nossa dramaturgia ao
utilizar os teatros como planetários, seguiremos nos movendo sobre
o solo frágil de uma ciência muito antiga: a mecânica newtoniana. ${ }^{13}$

O teatro épico como planetário já surgia assim como forma historicizada e limitada. Durante os anos 40, data da redação da obra a que pertence o trecho acima, $A$ compra do Latão, Brecht já via em sua própria prática e teorização dificuldades colocadas pela avalanche de catástrofes que marcavam as mutações aceleradas do capitalismo. O planetário, com sua movimentação mecânica e transparente, já começava a dar sinais de desmoronamento, de que a orientação conduzida pelas estrelas estava em crise e em vias de extinção.

Crise similar já havia sido constatada por Georg Lukács, que abre o seu Teoria do

${ }^{13}$ BRECHT, Bertolt. Escritos sobre teatro,vol.2. Buenos Aires: Nueva Visión, 1975, p. 143-144 
Romance expondo tal situação histórica em que as antigas estrelas fixas demonstravam sua incapacidade de orientação:

\begin{abstract}
Afortunados os tempos para os quais o céu estrelado é o mapa dos caminhos transitáveis e a serem transitados, e cujos rumos a luz das estrelas ilumina. Tudo lhes é novo e no entanto familiar, aventuroso e no entanto próprio. O mundo é vasto, e no entanto é como a própria casa, pois o fogo que arde na alma é da mesma essência que as estrelas (...) Todo ato da alma torna-se, pois, significativo e integrado nessa dualidade: perfeito no sentido e perfeito para os sentidos; integrado, porque a alma repousa em si durante a ação; integrado, porque seu ato desprende-se dela e, tornado a si mesmo, encontra um centro próprio e traça a seu redor uma circunferência fechada. ${ }^{14}$
\end{abstract}

Esta circunferência fechada, em que se distingue nitidamente o eu e o todo, "a luz e o fogo", sem que se tornem, entretanto, alheios um ao outro, é a expressão de um mundo em que os modos de navegação tradicionais eram capazes de fornecer rota e sentido. Como bússola, procuraremos responder nesta pesquisa se ao romper com um processo de criação baseado na ideia de coletividade como metáfora desta circunferência fechada a II Trupe de Choque, durante a criação de Miopia, foi capaz de aproximar-se do teor de verdade de um mundo em que tais constelações há muito caíram do céu fixo.

Em 2004, início do processo de criação que esta dissertação pretende analisar, após um ano de improvisações e material cênico criado, a II Trupe escolheu como teia narrativa a ser seguida, labirinto-constelação em meio ao oceano incerto, um fato simples: a expulsão violenta de desempregados da chamada "praça dos desempregados", em São Paulo, e a fundação de uma cidade utópica nos confins do Mato Grosso, onde foram jogados no ano de 1935, ano da "Intentona Comunista". O fato real e inspirador fora retirado de um trecho do historiador Leôncio Basbaum:

Por volta de 1931 havia no Brasil cerca de 2 milhões de desempregados ou semi-desempregados (que trabalhavam três ou quatro dias por semana). Em São Paulo a situação não era melhor. Os desempregados costumavam reunir-se, diariamente, no Largo de São Bento, onde matavam o tempo discutindo futebol ou política, aguardando a chegada de alguém precisando de operários. Em dado momento, a partir de certo dia, começaram a aparecer "tintureiros" da polícia, que cercavam os operários na praça, bloqueando as saídas. Os que não conseguiam escapar eram jogados nos tintureiros e, a partir daí, não mais se obtinha deles

\footnotetext{
${ }^{14}$ LUKÁCS, Georg. A teoria do romance. São Paulo: Duas Cidades, Ed. 34, 2000, p. 25.
} 
notícias. Isso aconteceu durante vários dias seguidos até que a praça ficou deserta. Era sem dúvida uma nova forma de acabar com o desemprego: prendendo e deportando os desempregados.

Segundo se soube na época, eram jogados na fronteira com Mato Grosso. ${ }^{15}$

Ao escolher o tema da tentativa de revolução comunista em 1935 no Brasil, a II Trupe de Choque debruçou-se sobre um dos momentos mais contraditórios da história brasileira, chamado pela história oficial de "Intentona". A abordagem crítica desse período histórico interessava não só como oportunidade de pesquisa para uma elaboração criativa e dialética de conteúdos históricos em uma nova forma teatral mas era também a escolha política de falar sobre o presente.

O ano em questão, 1935, além de marcado pelas fraturas da luta revolucionária abafada, representou um momento de crise no governo Vargas e em suas alianças oligárquicas, abismo que empurraria o país para a ditadura do Estado Novo dois anos depois, momento em que o projeto de desenvolvimento do capitalismo por aqui era questionado e emergia com as suas principais contradições expostas.

Durante todo o processo de pesquisa e de criação desenvolvido pela II Trupe de Choque, as cenas orientavam-se por tentar revelar que tais contradições, de um desenvolvimento aos saltos em um país miserável e periférico, formaram sementes para o tempo presente. Essa corrida agônica desorientou-se pelo labirinto da criação chocando-se em diversas miragens de saídas possíveis e a forma teatral resultante desse processo é puro aniquilar-se, interromper-se, sacrificar-se, o que não deixa, paradoxalmente, nesta sua irrealização, de ser testemunho do momento histórico de agora. Em que medida a obra artística criada, a peça Miopia, consegue configurar esta espécie de testemunho é o que pretendemos investigar.

Para o coletivo de criadores, a escolha da "praça dos desempregados" significava o "salto de tigre" do passado que invade o presente, de que nos fala Walter Benjamin em suas Teses sobre a filosofia da história. A revelação das contradições históricas que marcaram o país em 1935 só interessaria se servisse à criação de um espetáculo teatral capaz de desnudar os véus do tempo: de fazer emergir, a partir de um aprofundamento do passado, as contradições do presente.

A tentativa empreendida em Miopia era fazer emergir aquela presença dos dois âmbitos temporais de que nos fala Walter Benjamin a respeito do Romance dos três vinténs, de Brecht: "ele conjuga épocas, situando seus gângsteres numa Londres que

\footnotetext{
${ }^{15}$ BASBAUM, Leôncio. História sincera da República. São Paulo: Difel, 1978, p. 145.
} 
tem o ritmo e o aspecto dos tempos de Dickens. As circunstâncias da vida privada são de ontem, as da luta de classe, as de hoje. Esses londrinos não têm telefone, mas a sua polícia já usa tanques." A família retratada em Miopia, seguindo a inspiração brechtiana, não tem ideia do que seja a televisão mas se debate nos conflitos da "greve do olhar", organizada pelos habitantes da fictícia cidade de Miopia em uma resistência trágico/farsesca contra a "peste das imagens", flagelo imaginário que marca a narrativa da peça. Tais transformações entre momentos históricos distintos em suas facetas de vida privada e de luta de classes são objeto deste trabalho, que procurará ler nas fraturas da forma do espetáculo Miopia possibilidades e impossibilidades do teatro épico na realidade brasileira atual.

O primeiro capítulo dessa dissertação apresenta os pressupostos formulados inicialmente durante a pesquisa e o processo de criação que deram origem à Miopia. Através da análise de alguns fragmentos da peça, abordamos os conceitos de sociedade disciplinar e de controle, buscando demonstrar como o modo de produção da peça esteve presente no seu resultado final, condicionando a relação com o público, desmentindo conceitos presentes nas intenções iniciais da II Trupe de Choque e configurando alguns aspectos da máscara mortuária labiríntica que apegou-se irremediavelmente às feições do espetáculo teatral criado.

Durante o segundo capítulo, narramos a fracassada tentativa empreendida pelo grupo - na busca por criar uma forma teatral capaz de problematizar a realidade contemporânea em toda a sua complexidade e dinamismo - de acertar contas com o avanço das forças produtivas teatrais do longo século XX, afastando-se, para isso, do modo de produção capitalista hegemônico. Se, considerando a definição dada por István Mészáros, tal modelo caracteriza-se pelo tripé que envolve divisão social do trabalho, hierarquia dessas mesmas relações e produção de mercadorias, as contradições vividas pela II Trupe de Choque durante a tentativa de desenvolver um modo socializado de criação podem apontar que o paradigma de coletivização da criação seguido, inspirado pela experiência socialista de vertente soviética - horizonte histórico do teatro épico -, não foi suficientemente problematizado pelos criadores envolvidos na construção de Miopia.

No terceiro capítulo, abordamos, em torno de uma reflexão sobre o conceito de mímesis, os procedimentos de dissolução da autoria empregados durante o processo de criação da peça: o acúmulo de diversas referências teatrais e literárias estudadas gerou em Miopia uma aparência de soterramento, já que esta diversidade formal surge sempre 
em inacabamento, através de um processo sucessivo de destruição dessas referências, em uma busca contínua e fracassada por adaptá-las aos conteúdos históricos presentes que o grupo insistia em configurar.

O quarto capítulo expõe com detalhamento o principal desses processos de destruição e soterramento: a relação que os autores de Miopia estabeleceram, ao longo do processo de criação, com os paradigmas do teatro épico de Brecht. Tal modelo é apresentado como insuficiente para tratar da realidade brasileira contemporânea, percepção que a II Trupe de Choque nunca chegou a formular claramente durante a sua criação, dando ao resultado final da peça características formais que podem ser compreendidas sob os conceitos de tragédia e de dialética paralisada.

O quinto capítulo retrata o tratamento que a peça dá ao conteúdo e período histórico que foram os pontos de partida da pesquisa. Na tentativa de promover relações dialéticas entre o período histórico escolhido, os anos 30, marcados no Brasil pelo governo Vargas e pela Intentona Comunista de 1935, e o presente, Miopia apresenta a derrocada dos objetivos iniciais de seus criadores, trata de uma possível revolução no Brasil, e acaba por retratar as vítimas do processo de desenvolvimento do capital por aqui, olhando estas vozes abafadas sob o ponto de vista do lixo: o lixo do espaço cênico e de suas dramaturgias e o lixo de seres humanos mercantilizados e descartados como refugo.

O sexto capítulo trata da contradição central que dá forma ao labirinto Miopia: o embate, que permanece não resolvido no resultado final da peça, entre texto e cena. Expusemos nesse capítulo o desenvolvimento do processo de criação em estrita relação com dois espaços antagônicos que o abrigaram: primeiro uma casa e depois a Usina de Compostagem de Lixo de São Mateus. A encenação, ao invés de procurar superar tal conflito - já que o texto foi criado durante a etapa do processo desenvolvida na casa e, com a mudança para a Usina, todas as propostas de encenação iniciais foram abandonadas -, conserva a versão integral do texto e sobrepõe ao seu sentido original diversas camadas de sentidos contraditórios, como se estivéssemos diante de ruínas sedimentadas pela sucessiva ação do tempo.

Por fim, durante a conclusão, recuperamos as diversas tentativas, empreendidas nos capítulos anteriores, de definir e precisar a forma labirinto, conceito criado para analisar a peça. Preferimos manter o caráter fragmentário de tal reflexão, já que apresentamos o processo de criação teatral contemporâneo como um sucessivo embate com suas contradições, sem a pretensão de determinar saídas ou constelações 
transparentes que possam nos guiar para fora deste labirinto. Reside nessa sua impossibilidade, e nos seu acúmulo de derrotas, o interesse de Miopia.

Para terminarmos recuperando a imagem da agonia e do ágon, talvez possamos afirmar que a tarefa da crítica de Miopia significaria olhar para trás, distantes que estamos da linha de chegada, percebendo nas máscaras mortuárias utilizadas pelos corredores perdidos, a face desses tempos de labirinto, questionando-nos ao mesmo tempo, tateantes, se tal experiência reflexiva, afogada no olho no olho com as máscaras, é possível. 


\section{Saída interrompida 1: o percurso lixo/Primeira crise}

Nesse estágio, a contradição entre forças produtivas e relações de produção se tornou tão ampla e tão manifesta que não mais podia ser dominada racionalmente, não mais podia ser expressa. Não há véu tecnológico, não há véu ideológico que possa continuar a encobri-la. O único modo de manifestar-se que lhe resta é a contradição nua e crua, irracionalidade convertida em racionalidade; só uma consciência falsa pode ainda suportá-la, uma consciência que se tornou indiferente à própria diferença entre verdadeiro e falso.(...) Em que antilinguagem a razão ainda pode se expressar nesse caso? O que se encena aí não é mais uma sátira, e, diante da seriedade do terror, a ironia se transforma em cinismo $^{16}$.

\section{I.1. A Dialética e a disciplina no teatro}

Miopia surgiu de uma pesquisa teatral desenvolvida, durante mais de dois anos, a partir da "dialética no teatro", tendo como objeto de estudo a obra de três importantes encenadores do século XX: Constantin Stanislavski, Bertolt Brecht e Vsevolod Meyerhold, à luz do pensamento de importantes filósofos dialéticos, como G. W. F. Hegel, Karl Marx e Walter Benjamin. A pesquisa partiu da hipótese de que o pensamento dialético seria estruturante do teatro praticado pelos três encenadores escolhidos e, por isso, tais conceitos poderiam ser identificados e recriados por um grupo teatral interessado em desenvolver novas técnicas e metodologias para o trabalho do ator, da cena teatral e de sua literatura.

Este processo de "crítica das armas" buscava, na "arma da crítica" teatral, oferecer

\footnotetext{
${ }^{16}$ MARCUSE, Herbert. Prólogo ao 18 de brumário de Luís Bonaparte. In: MARX, Karl. O 18 de brumário de Luís Bonaparte. São Paulo: Boitempo, 2011, p. 15.
} 
uma visão da sociedade em que houvesse uma identificação das forças, dos processos e das relações de causalidade implicadas. Para travar esta "luta do discurso", a II Trupe de Choque construiu dramaturgias inéditas, de forma compartilhada, a partir das improvisações dos atores e da reelaboração dada por mim como diretor e dramaturgo e pelos demais criadores envolvidos no projeto: cenógrafo, figurinista e iluminador. Paralelamente aos ensaios, o grupo ministrou oficinas artísticas gratuitas ocupando a Usina de Compostagem de Lixo de São Mateus, zona leste de São Paulo, procurando estabelecer um diálogo com os moradores das favelas e conjuntos habitacionais da região, bem como com a Cooperativa de Lixo reciclável que também utilizava o espaço da usina. O objetivo central do projeto, em sua vertente artístico-pedagógica, era naquele momento o de "buscar a formação de público e de artistas conscientes da totalidade das contradições que conferem movimento à realidade social que os cerca"17.

Foram realizadas na Usina de Compostagem de Lixo de São Mateus, de maio de 2005 a abril de 2006, as seguintes oficinas que o grupo chamou de Oficinas Peripatéticas: Teatro, Alfabetização para adultos, Música, Artes Plásticas, Iluminação e fotografia, Interpretação teatral e Direção teatral.

Os discípulos de Aristóteles costumavam ter mais do que lições de filosofia: procuravam vivenciar o saber em um processo de discussão e aprendizagem em que o caminho se construía a partir dos passos, maleável em fantasia como se desenho diurno, feito de nuvem ou de estrela. Por isso, eram chamados de peripatétikos; aqueles que ensinam caminhando. A saber, Aristóteles costumava ministrar suas aulas enquanto caminhava com seus alunos pelas ruas de Atenas. ${ }^{18}$

As Oficinas Peripatéticas procuravam romper com a divisão entre teoria e prática, dando nova dimensão a questões filosóficas a partir do teatro. O que a II Trupe chamou de "teatro peripatético" baseava-se no objetivo artístico-pedagógico de estimular o pensamento crítico e criativo em duas etapas, dialeticamente interligadas: a realização das oficinas e a montagem de um espetáculo. As oficinas foram ministradas pelos integrantes do grupo, estabelecendo com os demais participantes uma relação de mútuo aprendizado:

O conhecimento teatral e a pesquisa contaminaram-se, fazendo com que cada núcleo fosse espaço para o desenvolvimento de

\footnotetext{
${ }^{17}$ ALMEIDA, Ligia Marina; FARIA, Fernanda; DELMANTO, Ivan, et al. Anjos do desespero. Projeto de pesquisa teatral. Contemplado pela V Edição da Lei de Fomento ao Teatro do Município de São Paulo, 2005, p. 32. Inédito. Disponível para consulta na Divisão de Fomento da Secretaria Municipal de Cultura.

${ }^{18}$ Idem, p. 23
} 
formas teatrais pertencentes a cada grupo de participantes e para a descoberta conjunta do universo da exclusão social. ${ }^{19}$

Desta forma, pretendia-se que o processo criativo não fosse interrompido durante as oficinas mas que, pelo contrário, que se desenvolvesse e aprofundasse, ligando arte e pedagogia em um único percurso. Questões e temas pertencentes à pesquisa (o lixo, a velocidade do tempo, o espaço urbano como ruína, o corpo como mercadoria e dejeto) foram compartilhadas entre os participantes (moradores do entorno da usina, funcionários da cooperativa de reciclagem de lixo da usina e estudantes de arte vindos de diversas regiões da cidade) e integrantes do grupo, buscando constituir um grande processo de criação coletivizada.

As oficinas artísticas possibilitaram, aliadas à realização de ensaios abertos e leituras cênicas, compartilhar os resultados alcançados pelo grupo em seus estudos e no seu processo de criação. Para o desenvolvimento do espetáculo, as oficinas proporcionaram o diálogo com pessoas das mais diversas experiências teatrais, vindas principalmente de estratos sociais "desfiliados" $" 20$, elaborando forma e conteúdo para trazer luz às relações econômicas que formam e reformam as experiências cotidianas

\footnotetext{
19 PEIXOTO, Elenira. "Diário de trabalho". In: ALMEIDA, Ligia Marina, FARIA, Fernanda, DELMANTO, Ivan, et al. Anjos do desespero. Relatório de terceira etapa de pesquisa. Apresentado à Secretaria de Cultura do Município de São Paulo, 2006. P. 99. Inédito. Disponível para consulta na Divisão de Fomento da Secretaria Municipal de Cultura.

20 Utilizaremos nesta dissertação o termo "desfiliado" como sinônimo de "dissociado, invalidado, desqualificado" e o distinguimos de "excluído", já que este último, como esclarece Foucault, não é correto para explicar a forma de poder exercida nas sociedades normalizadoras. Estas não excluem, como na Idade Média se fazia em relação aos leprosos. Inversamente, elas incluem, como se pode ver no tratamento da peste dos séculos XVII-XVIII. Trata-se de um poder meticuloso, de um exame constante e perpétuo, de um controle sutil e cada vez mais próximo, que individualiza e classifica as pequenas diferenças em relação a uma norma, que é, simultaneamente, qualificação e coerção. Não se trata, portanto, de uma demarcação rígida entre dois grupos, na qual um deles é rejeitado e expulso ou marginalizado. Trata-se de um continuum que vai do normal ao anormal e que não se pretende definitivo, já que está sujeito a tecnologias de intervenção que podem "curar". Deste modo, se o poder normalizador também separa e coloca à parte, não é para expulsar, mas é uma medida extrema para melhor intervir e "recuperar". Os objetivos buscados por estas duas formas de poder também são diferentes. Enquanto que na exclusão do leproso procura-se uma purificação da comunidade por meio de um rito, nas sociedades normalizadoras busca-se uma maximização da saúde, da vida, da longevidade e da força dos indivíduos e das populações através de tecnologias correcionais (cf. FOUCAULT, Michel Os Anormais - curso no Collège de France 1974-1975. São Paulo: Martins Fontes, 2002, pp. $54-59$ e Vigiar e Punir. Petrópolis: Ed. Vozes, pp. 162-165).
} 
dos desfiliados da sociabilidade da mercadoria.

As apresentações de Miopia na Usina de lixo buscavam, como objetivo político, revitalizar um espaço público abandonado, dando-lhe através do teatro uma dimensão cultural ainda não realizada. Apresentar um espetáculo na Usina possibilitou, como objetivo estético, estabelecer com o espaço não edificado para fins teatrais um diálogo alegórico, já que os temas tratados em Miopia (o lixo como metáfora e consequência da degradação das relações sociais mediadas pela mercadoria no mundo capitalista) puderam traçar relações com um lugar habitado por imensas máquinas abandonadas, incapazes de digerir a quantidade crescente de lixo produzido pela cidade.

O grande espaço da Usina, percorrido pelo público seguindo a antiga trajetória do lixo ao ser triturado, comprimido e embalado pelas máquinas, como se fossem também os espectadores peças da engrenagem de um mundo tóxico, deslocou a experimentação do grupo com a forma teatral épica: a fragmentação da narrativa foi acompanhada pela multiplicidade de espaços da Usina; as máquinas, engrenagens e a vegetação criavam imagens e símbolos ao serem ocupadas pelos atores; pretendia-se que o público - ao acompanhar a narrativa por dentro -, estabelecesse com o espetáculo teatral uma relação de participação ativa, chamado constantemente a completar as lacunas com sua reflexão e criação, encontrando um caminho próprio para o labirinto urbano de Miopia.

Não houve, nesse resultado da peça apresentado, a aplicação imediata do que o grupo investigou e sistematizou como "pressupostos dialéticos a serem testados". Durante a pesquisa e a criação da peça, a abordagem crítica e prática de conceitos relacionados à filosofia dialética buscou revelar na obra de Brecht e de dois dos seus principais antecessores e interlocutores, Meyerhold e Stanislavski, procedimentos estéticos formadores de um teatro dialético, seja em sua dramaturgia, em sua encenação ou no trabalho de seus atores. Aspectos como o estranhamento explorado por Brecht, a biomecânica como método de treinamento do ator ou o trabalho com as ações físicas sugerido por Stanislavski não emergiram de maneira clara no tecido final de Miopia, mas foram apresentados em sua agonia.

O grupo procurou chamar este percurso de "A Dialética no teatro" porque o objetivo inicial não era o de sistematizar os princípios constitutivos do teatro dialético de Brecht (o primeiro a adotar esta designação) mas sim elaborar, de acordo com o conteúdo da peça, uma forma artística baseada na recriação de pressupostos dialéticos intuídos e praticados pelos encenadores em questão. A suspensão desses pressupostos foi buscada não através de uma amortização das diferenças (entre as doutrinas e ideias) 
mas, ao contrário, aguçando tais diferenças, buscando trabalhar a partir de contradições:

Na suspensão, o que é suspenso é abolido, suprimido - num certo sentido. Não obstante, em outro sentido, o suspenso não deixa de existir, não recai no puro e simples nada, ao contrário, é elevado a nível superior. E isso porque ele serviu de etapa, de mediação para a obtenção do resultado superior, essencialmente diverso dos elementos anteriores e não mera justaposição destes. ${ }^{21}$

Foram importantes, durante toda a etapa inicial de pesquisa, realizada ainda fora da Usina, estudos conduzidos coletivamente que tinham por objetivo relacionar estímulos teóricos (fragmentos de textos filosóficos dialéticos) à prática de exercícios inspirados nas metodologias de Brecht, Stanislavski e Meyerhold. O conceito de estúdio, inspirado na experiência de Meyerhold, serviu de norte metodológico a esta etapa de trabalho:

O Teatro-Estúdio, como nomeou Meyerhold a primeira filial do Teatro de Arte [de Moscou], não objetivava ser nem uma escola para principiantes nem um teatro convencional. (...) Meyerhold criticava diretamente o naturalismo, e afirmava a necessidade de superação deste por intermédio de métodos modernos para a arte dramática, visando satisfazer ao espectador inteligente que exige novas formas.(...) Ainda que Stanislávski reconhecesse não ser o jogo naturalista a última palavra, para ele o novo teatro deveria dar continuidade aos avanços conquistados pelo Teatro de Arte, e sugeria que fosse impressa uma forte disciplina nas atividades do Teatro-Estúdio. ${ }^{22}$

Os ensaios foram conduzidos nesse período a partir da recriação da proposta de estúdio: não havia inicialmente nenhum material textual teatral a nortear as pesquisas, nenhuma ideia de narrativa ou de personagens, apenas o fio tenso da busca por uma renovação do teatro épico sistematizado por Brecht, a partir de uma investigação dos seus antecessores e referências teóricas: a filosofia dialética e os procedimentos de Meyerhold e Stanislavski.

A partir da inspiração meyerholdiana, os ensaios organizavam-se de maneira rígida, alternando períodos de experimentação de exercícios corporais com discussões de leituras. Cenas eram depois improvisadas pelos atores a partir dos exercícios e de conceitos extraídos das leituras. Esta rigidez disciplinar, caracterizada por regras de

${ }^{21}$ ALMEIDA, Ligia Marina; FARIA, Fernanda; DELMANTO, Ivan, et al. Anjos do desespero. Projeto de pesquisa teatral. Contemplado pela V Edição da Lei de Fomento ao Teatro do Município de São Paulo, 2005, p. 42. Inédito. Disponível para consulta na Divisão de Fomento da Secretaria Municipal de Cultura.

${ }^{22}$ SANTOS, Maria T. L.. Na cena do Dr. Dapertutto. São Paulo: Perspectiva, 2010, p.21. 
conduta profissional (horários, faltas etc.) debatidas por horas e horas a fio, em busca de sua cada vez mais rigorosa aplicação, marcou indissoluvelmente todo o processo de criação e talvez esteja presente no resultado final a que chegou a peça apresentada.

Apesar de baseada em pactos coletivos, a minha direção foi responsável durante todo o processo por zelar por esse espaço regrado da pesquisa e do estúdio, como se as descobertas artísticas dependessem de um controle externo constante, de responsabilidade do encenador, visto nesse espaço como delegado e representante do grupo. Desta forma, por mais dedicados e disciplinados que os atores fossem, as regras pareciam sempre insuficientes, para todos, e as discussões sobre o não cumprimento dos acordos coletivos eram frequentes. O processo foi movimentado por essas crises constantes, tanto organizacionais quanto artísticas, e por inúmeras vezes o espaço de pesquisa, voltado para o erro e para o abismo, foi interrompido coletivamente, tal o zelo pela "disciplina" e pela "correção nas condutas".

Tais tensões estão presentes no tecido de Miopia, seja em forma de contradições produtivas, que serviram ao ambiente caótico, de crise constante, que a peça propunha ao público - graças aos diversos materiais criados, que não tiveram uma organização coerente e harmônica -; seja em forma de uma certa padronização nos corpos e nos registros de interpretação dos atores, que ao adaptarem-se a essa disciplina comum geraram uma presença cênica coletivizada quase que à maneira militar.

$\mathrm{O}$ "controle" internalizado pelo grupo podia ser testemunhado em cena quando o público era conduzido de maneira rígida, sem espaço e tempo sequer para observar as múltiplas imagens que o espaço da Usina propunha. O risco - gerado por essa disciplina - a que muitas vezes o público era submetido, obrigados que eram todos os espectadores a percorrer rapidamente corredores escuros e escadas estreitas, contribuía para um estado de tensão geral. No entanto, há que se pensar se tal administração, presente nos corpos "treinados" dos atores e na condução do público, não representa muito mais o momento histórico passado em que surge o teatro épico, marcado pelo que Foucault chama de "sociedade disciplinar", do que o presente do capitalismo tardio, estágio que a II Trupe pretendia retratar:

Nas sociedades de controle, ao contrário, o essencial não é mais uma assinatura e nem um número, mas uma cifra: a cifra é uma senha, ao passo que as sociedades disciplinares são reguladas por palavras de ordem. A linguagem numérica do controle é feita de cifras, que marcam o acesso à informação, ou a rejeição. Não se está mais diante do par massa-indivíduo. Os indivíduos tornaram-se "dividuais", divisíveis, e as massas tornaram-se amostras, dados, 
mercados ou "bancos". ${ }^{23}$

Neste texto de 1992, Post-Scriptum sobre a sociedade de controle, Gilles Deleuze destaca que as sociedades disciplinares analisadas por Foucault encontram-se em crise desde meados do século XX. Por todos os lados seria possível observar os sinais de esgotamento da economia de poder característica a estas sociedades, fundada sobretudo na tecnologia do confinamento para a formatação de indivíduos, ou como prefere dizer Foucault, em subjetividades assujeitadas. Em meio a este mundo dos confinamentos que agoniza, Deleuze procura chamar a atenção para a "instalação de novas forças", novas tecnologias de poder, sob novo paradigma chamado agora de "controle", que viria, aos poucos, substituir as relações de poder que se baseiam nos grandes meios de confinamento para operar processos de individuação por sujeição.

O controle não significaria o fim da disciplina, nem mesmo a extinção do poder soberano. Segundo o autor, pesquisas deveriam apontar como essas diferentes tecnologias de poder iriam se relacionar e configurar novas faces do biopoder ${ }^{24}$. Deleuze traça no texto as diferenças entre essas formas de manifestação do poder. A primeira situa-se no fato de que enquanto a disciplina é "de longa duração, infinita e descontínua", produtora de moldes e moldagens, o controle é de "curto prazo, rotação rápida, contínuo e ilimitado", funcionando por meio de fluxos e modulações instáveis e autodeformantes. As relações de poder que produzem o "homem confinado" perdem lugar para as que criam o "homem endividado". O filósofo francês adianta que não estamos mais diante do par "indivíduo/massa", como ocorria sob a égide da disciplina, mas defronte aos "divíduos" (indivíduos divisíveis) imersos em bancos de dados, amostras, mercados. Por fim, o controle não seria simplesmente uma evolução tecnológica, embora "produções farmacêuticas extraordinárias, manipulações genéticas, formações nucleares" e inovações em comunicação e informática venham interferir nessa realidade que aos poucos se configura. Antes de tudo, o controle refere-se a uma mutação do capitalismo, o capitalismo da sobreprodução, no qual a forma empresa é multiplicada ao extremo e tende a se impor como a forma "universal".

${ }^{23}$ DELEUZE, Gilles. Conversações. São Paulo: Ed. 34, 1998, p. 222.

${ }^{24}$ Foucault chamou de biopoder, em seu livro História da Sexualidade I - A vontade de saber, uma nova modalidade de poder, desenvolvida a partir do século XVIII, incumbida de gerir a vida. Ao aprofundar essa noção, Foucault evidencia a criação de dispositivos e mecanismos de normalização e regulação da vida. Tais concepções sobre o poder inauguram o conceito de biopolítica. 
Referindo-se ao ideal da administração burocrática, Max Weber o descrevia no início do século XX da seguinte forma: "proceder sine ira et studio, ou seja, sem a menor influência de motivos pessoais e sem influências sentimentais de espécie alguma [...]". A exclusão dos sentimentos e preferências pessoais, assim como de toda espontaneidade e iniciativa própria nos procedimentos burocráticos pode ser bem resumida pela anedota de Zygmunt Bauman sobre as fábricas fordistas, na qual escreve que "as identidades e laços pessoais eram pendurados no cabide da porta da entrada junto com os chapéus, guarda-chuvas e capotes" 25 .

Se não estivermos errados, essas relações entre diversas formas de assujeitamento estão presentes em Miopia de forma irrefletida e enviesada. Como um primeiro exemplo, podemos nos deter sobre o prólogo da peça:

\section{PRÓLOGO}

Daniel está sentado no ônibus. Público sobe e o ônibus sai. Daniel levanta-se durante o trajeto e distribui blusas antitóxico para o público. Daniel: "Vistam enquanto podem. Vistam enquanto podem". ${ }^{26}$

O primeiro aspecto a ser observado é que a cena não chegou a entrar no texto da peça: construída à maneira de um canovaccio, o roteiro foi improvisado durante a temporada da peça e a cena surgiu de uma necessidade prosaica: o frio que a partir do mês de maio assolava o público, enquanto este se via percorrendo o espaços ao ar livre e as frias e amplas galerias da usina abandonada. Para resolver o problema, foram compradas trinta roupas utilizadas em limpeza industrial, formadas por calça e agasalho com capuz, que eram distribuídas aos espectadores.

A opção por entregar as roupas logo no início da peça, mas como parte da cena, integra a mesma escolha artística de fazer com que o ator, sem representar um personagem, mas como "Daniel”, apenas realizasse a ação: a intenção era embaralhar o espaço ficcional e a realidade, fazendo com que o público, prestes a entrar de fato em uma usina de lixo, vivesse a experiência deste estado de dúvida e suspensão. A entrega do figurino era executada enquanto todos ainda estavam no ônibus, quando este fazia um pequeno trajeto, levando o público da entrada do espaço até o alto do morro em que a primeira plataforma da usina a ser utilizada se localizava. Ao receber o traje, a maior

\footnotetext{
${ }^{25}$ ANDRADE, Daniel Pereira. Dispositivo de controle emocional. Poder e emoções na economia contemporânea. 2009, p. 13. Exame de qualificação de doutorado apresentado ao Departamento de Sociologia da Faculdade de Filosofia, Letras e Ciências Humanas da Universidade de São Paulo.

${ }^{26}$ DELMANTO, Ivan. Caderno de direção - 2006. Inédito, 2006, p. 98.
} 
parte do público ignorava as ordens de Daniel e geralmente sorria.

O procedimento disciplinar de forçar o público a receber as roupas "antitóxico", realizado com extrema dureza por Daniel, ele também já vestido com o agasalho branco, ganhava ares de controle sutil, mas igualmente enervante, quando o público descia do ônibus e, em meio ao rasgante frio do alto do morro, via-se diante da arquitetura monstruosa e abandonada da Usina: não havia outra opção a não ser vestir o traje para proteger-se do lixo e do frio. Ao vestir o figurino, o público tornava-se parte da representação, ser controlado por todas as regras deste espaço de trânsito entre a ficção e o real.

Pouco menos de um século depois da apresentação weberiana do tipo ideal da burocracia, diversos estudiosos do novo mundo corporativo apontam para um processo em que as emoções passam a ser um elemento essencial para as organizações obterem vantagens competitivas, constituindo um diferencial capaz de definir o sucesso ou o fracasso de uma carreira profissional.

Este dispositivo emocional poderia ser considerado uma espécie de biopoder, ou seja, uma subsunção da vida pelo poder, mas de caráter diferenciado por visar o corpo em um aspecto inédito. Michel Foucault aponta para duas dimensões do corpo que seriam alvo do biopoder: o organismo individual dotado de capacidades, que deve se tornar simultaneamente útil e dócil por meio da ação dos mecanismos disciplinares; e o corpo coletivo da população, onde são visados os aspectos de conjunto de uma massa de seres vivos, de modo a regulamentar fenômenos globais próprios à vida. $\mathrm{O}$ dispositivo emocional constitui uma terceira dimensão do biopoder, irredutível às outras duas, pois age sobre o corpo individual e/ou coletivo visando sua dimensão perceptiva, suas sensações, sentimentos e emoções. As experiências vividas do sujeito seriam o alvo a ser gerido e modulado pelos mecanismos de poder emocional.

Do ponto de vista de uma análise crítica, a partir das definições sugeridas por Deleuze e Foucault, o que caberia questionar seria a história de como as emoções têm sido construídas, governadas e mobilizadas pelas relações de poder (ainda que por vezes de modo inteiramente superficial) e quais as novas formas de sujeição e desigualdade às quais esse dispositivo dá origem. Em outros termos, seria possível desnaturalizar a atual ordem emocional, contornar a evidência familiar das subjetividades assujeitadas associadas a ela, observar quais os limites que tal ordem impõe à nossa experiência e explicitar a implementação de uma nova forma de dominação. Mas tal questionamento não emergiu durante o processo de criação da peça que estamos analisando aqui. 
Se as relações sociais que os autores de Miopia pretendiam tematizar eram aquelas mediadas por imagens, tornadas mercadorias, talvez a condução do público pudesse dar-se por senhas e não por palavras de ordem como estas, ditas por um dos personagens narradores na transição entre as cenas 19 e 20 e 23 e 24 :

ANTENOR - Vocês não vêm?

$$
\text { ANTENOR - Venham. }{ }^{27}
$$

Se, inspirados pelos estúdios de Meyerhold, o objetivo do grupo era "satisfazer ao espectador inteligente que exige novas formas", a forma de administração disciplinar poderia ser substituída pelo controle, em que o próprio público seria responsabilizado e culpabilizado por suas escolhas, aparentemente "livres". Tal procedimento é esboçado na atuação de Daniel, citada acima, mas não é de novo explorado no restante da peça. Renata Salecl, em livro que discute a tirania das escolhas em um mundo sem limites, a partir da ideologia da autoconstrução do eu que sustenta a sociedade de consumo, afirma que:

A ideia de que supostamente somos capazes de nos administrar, e que existe uma escolha sobre como lidamos com nossas emoções, está ligada à percepção do eu que domina a sociedade no capitalismo tardio. Hoje, o verdadeiro eu é cada vez mais autoconstruído e, mais do que isso, um projeto individual. ${ }^{28}$

Nas palavras do psicanalista Charles Melman, trata-se de:

uma subjetividade que se crê liberada de toda dívida para com as gerações precedentes", de uma "cultura que recomenda a livre expressão" a partir da emergência de uma nova economia psíquica formatada como consequência de um progresso considerável, que indicou que "o céu está vazio, tanto de Deus quanto de ideologias, de promessas, de referências, de prescrições, e que os indivíduos têm que se determinar por eles mesmos, singular e coletivamente. ${ }^{29}$

No entanto, o que as práticas da sociedade disciplinar presentes ininterruptamente em Miopia poderiam questionar é se não estamos diante de uma situação fraturada por mais contradições: a persistência de formas de poder disciplinar em uma peça que pretende tratar dos movimentos "ondulatórios" da sociedade mediada por imagens pode

\footnotetext{
${ }^{27}$ ALMEIDA, Ligia Marina; DELMANTO, Ivan; FARIA, Fernanda, et al. Miopia. Inédito, 2006, p. 1725 .

${ }^{28}$ SALECL, Renata. Sobre a felicidade: ansiedade e consumo na era do hipercapitalismo. São Paulo: Alameda situações. 2005, p. 14-15.

${ }^{29}$ MELMAN, C. Charles. O homem sem gravidade. Rio de Janeiro: Companhia de Freud, 2003, p.12-16.
} 
sugerir, nos bastidores do discurso do eu autônomo, procedimentos de controle extremamente rígidos e nada "flexíveis":

\begin{abstract}
A novidade, que este artigo pretende investigar, é o momento em que esse discurso começa a se tornar hegemônico e a atualizar a ideologia do eu autônomo. Aqui, assume-se a concepção de ideologia do filósofo e estudioso da psicanálise Slavoj Zizek, que propõe que a ideologia tem a conotação de uma "fantasia social", cujo objetivo, em última instância, seria elevar algo "à condição de impossibilidade, como meio de adiar ou evitar o encontro com isso" (...). Como se verá ao longo deste artigo, a ideologia do eu autônomo, atualizada no discurso do consumo responsável, explicita bem a concepção zizequiana de ideologia, pois o sujeito é chamado "a decidir, mas ao mesmo tempo recebe a mensagem de que não está em posição efetiva de decidir". ${ }^{30}$
\end{abstract}

Tal temática tem sido amplamente relacionada às práticas de assujeitamento presentes no mundo contemporâneo, sendo a gestão do eu o mais importante papel que o sujeito é instado a assumir em um tipo de governmentality - termo cunhado por Michael Foucault - no qual a ideologia do indivíduo autônomo está ligada a novas regras políticas e econômicas. Governmentality propõe a ligação semântica do conceito de governar (gouverner) com os modos de pensar (mentalité), indicando que não é possível estudar as tecnologias de poder sem uma análise da racionalidade política que as suportam, sugerindo uma ligação muito próxima entre formas de poder e processos de subjetivação. Assim, todas as vezes que em Miopia os personagens convocavam o público a participar e a decidir, as escolhas já estavam há muito fechadas: independente da opção do público o caminho a seguir era sempre o mesmo, pré-determinado pela encenação, sem que houvesse espaço para o improviso ou para a mudança no destino dos personagens. É possível relacionar o modo de produção coletivo-disciplinado empregado pelo grupo durante o processo de criação com esta espécie de cena-rígida, em que a participação do público é um disfarce do controle e em que a atuação dos atores é guiada pelos ditames da encenação, vigorosamente marcada, distribuída no espaço e no tempo (diversas vezes acompanhei o espetáculo com um cronômetro e um metrônomo, para acompanhar e fiscalizar o tempo e o ritmo das menores reações, falas e movimentações dos atores. Tal procedimento também não era estranho a Meyerhold, que costumava chamar suas composições cênicas de "musicais". A questão não gira aqui em torno da validade estética do procedimento, mas em que medida este não

\footnotetext{
${ }^{30}$ FONTENELLE, Isleide. Fetiche do eu autônomo: consumo responsável, excesso e redenção como mercadoria. Inédito, 2010, p. 5.
} 
funciona como um dispositivo de controle dos atores, revelando na forma da peça uma realidade controlada contra a qual o discurso do grupo pretendia se insurgir).

Talvez as tecnologias de poder presentes e submersas na encenação de Miopia possam trazer-nos mais interrogações se pudermos ler nesta relação com o público um certo cinismo, ou, para formularmos em termos mais contraditórios, um controle disciplinar exercido de maneira cínica. Senão vejamos.

Peter Szondi, na Teoria do drama burguês, retoma Max Weber para apontar que um dos elementos constitutivos do espírito capitalista moderno, e não só desse, mas da cultura moderna - a conduta racional com base na ideia de vocação - nasceu do espírito da ascese cristã. A práxis ética do homem comum foi despojada assim de seu aspecto assistemático e não planejado e transformada em um método consequente para a conduta da vida inteira. Essa conduta é caracterizada por Max Weber como ascese intramundana.

A ascese tornar-se-ia assim uma virtude burguesa. Em sua análise do drama de Lillo, O mercador de Londres, Szondi nos mostra que a peça serve ao louvor e à expansão dessa virtude burguesa, e é primeiramente essa intenção, e não a condição social de seus personagens por si só, que faria da obra um drama burguês. Assim, o que construiria um drama burguês seria um tema ou motivo especificamente burguês. No caso de Lillo, este tema está ligado ao que Weber chama de ascese intramundana e a consequente racionalização e desencantamento do mundo burguês.

Se olharmos para a relação que os personagens/narradores de Miopia estabeleciam com o público talvez possamos identificar uma estrutura de sentimento da sociedade brasileira que dá forma ao espetáculo.

Raymond Williams, no seu livro Cultura ${ }^{31}$, propõe que os dados internos de uma obra de arte deverão evidenciar as relações do produtor e do produto cultural com as forças sociais e suas instituições e tradições, aspectos que formariam o que ele veio a chamar de estrutura de sentimentos. Williams diz que a forma artística é a expressão das estruturações do vivido na experiência histórica. Isso porque, para o autor, as práticas sociais e os hábitos mentais se confundem às formas de produção e de organização sócio-econômicas a ponto de estruturarem, em termos de sentido, a vida e suas experiências.

A partir dessa reflexão, Williams propõe a ideia de cultura comum, ordinária,

31 WILLIAMS, Raymond. Cultura. Rio de Janeiro: Paz e Terra, 1992. 
encravada no modo de vida da experiência cotidiana, como uma forma de se pensar o tecido histórico-social. Ao definir cultura como algo comum, Williams une modos de vida e produtos artísticos. Para haver uma análise coerente da cultura, seria necessária uma categoria que abarcasse esses termos ativos e flexíveis de mudança. Para isso, Williams cunhou a noção de estruturas de sentimento, definindo as experiências vividas em um determinado tempo e momento históricos:

Estamos então definindo esses elementos como uma "estrutura": como uma série, com relações internas específicas, ao mesmo tempo engrenadas e em tensão. Não obstante, estamos também definindo uma experiência social que está ainda em processo, com frequência ainda não reconhecida como social, mas como privada, idiossincrática, e mesmo isolada, mas que na análise (e raramente de outro modo) tem suas características emergentes, relacionadoras e dominantes e na verdade suas hierarquias específicas. ${ }^{32}$

Pode-se dizer, então, que a estrutura de sentimento é uma forma de incorporar as experiências e os processos sociais ao estudo da cultura, para analisar as condições das práticas sociais em um determinado momento histórico. Ao mesmo tempo em que as artes armazenam tal forma de estrutura, participam ativamente do processo de incorporação e formalização dessas experiências na vida social.

Assim, estrutura de sentimento trata-se de uma expressão cunhada para se referir a um conteúdo de experiências e de pensamento que, histórico em sua natureza, encontra a formalização mais específica nas obras de arte, marcando, por exemplo, a estrutura de peças, romances, filmes. Uma das modalidades de sua presença está em traços recorrentes de época, em convenções de gênero ou em outros dados estilísticoformais que definem o perfil de uma ou de um conjunto de obras.

Em Miopia, podemos identificar estruturas de sentimento se observarmos mais atentamente a relação da peça com o seu público. O público era conduzido, desde o início, por vários ambientes da Usina de Compostagem de Lixo, seguindo a antiga trajetória do lixo no local.

Em certas cenas, o público seguia o mesmo caminho que os atores e, quando chegava ao local, era disposto em uma arquibancada, sem nenhuma indicação precisa de que deveria sentar-se. Em outras cenas, ficava de pé, sem saber se deveria sentar, acompanhar as ordens dos personagens ou se poderia sequer encostar-se sobre as sujas paredes da usina de compostagem. Ao mesmo tempo, os discursos dos personagens por

\footnotetext{
32 WILLIAMS, Raymond. Marxismo e literatura. Rio de Janeiro: Zahar, 1979, p. 134.
} 
vezes eram dirigidos ao público, que em algumas circunstâncias levantava para participar da cena. Mas não participava. Era tratado, ao mesmo tempo, como público e como trabalhador, como público e como lixo, como espectador e como morador da cidade, como testemunha e como cúmplice.

Esta cumplicidade do público situa-o em uma posição distinta do contemplador esclarecido pensado pelo teatro épico de Brecht:

\begin{abstract}
Seria possível o prazer artístico sem a identificação, ou sobre outra base que não a da identificação? (...) Que atitude deve adotar o espectador nos novos teatros, se é negada a posição sonhadora, passiva, entregue ao destino? (...) Seria possível substituir o terror pela ânsia de saber ou a piedade pela ajuda? Poderia ser estabelecido um novo contato entre o palco e o espectador, isso se poderia constituir como uma nova base para o prazer artístico ${ }^{33}$
\end{abstract}

Este contato entre palco e espectador, baseado na "ânsia de saber" de um público interessado em descobrir os mecanismos sociais encobertos pela ideologia, estaria hoje, segundo a proposição original de Vladimir Safatle, próximo do seu esgotamento. Uma espécie de obsolescência do mascaramento ideológico indicaria que, de uma certa forma, as promessas de racionalização e de modernização da realidade social já teriam sido realizadas pela dinâmica do capitalismo. Teriam sido realizadas, entretanto, de maneira cínica: "o que significa que, de uma forma ou de outra, elas foram realizadas ${ }^{34}$." Esta realização cínica indicaria uma etapa da ideologia, narrada por Slavoj Zizek, a partir da seguinte metáfora: "eles sabem o que fazem, e mesmo assim o fazem". Ao contrário da frase compassiva de Cristo, o divíduo consumidor do capitalismo tardio não pode ser "perdoado por não saber o que faz": em um mundo em que os desejos e o inconsciente encontrar-se-iam colonizados pela forma mercadoria, que já realizou todas as promessas da modernidade esgotando-as, o capital expõe-se por inteiro, assume suas insuficiências, mas, afirmando-se como único horizonte visível e viável, ancora-se na postura de Ismênia que afirma diante de Antígona: "o impossível é melhor nem tentar". Esta postura cínica pauta a relação de Miopia com o seu público.

Em seu livro Cinismo e falência da crítica, Vladimir Safatle analisa o cinismo como uma patologia social. Observa que nos processos de racionalização que compõem a forma de vida hegemônica (que é a base para o padrão que organiza o conjunto da vida social) há um conjunto de valores e regras, mas, além disso, há um modo de seguir

\footnotetext{
${ }^{33}$ BRECHT, Bertolt. Escritos sobre teatro. Volume 1. Buenos Aires: Ediciones nueva vision, 1973, p. 103.

${ }^{34}$ SAFATLE, Vladimir. Cinismo e falência da crítica. São Paulo: Boitempo, 2008, p.69.
} 
esses valores e regras: haveria assim várias maneiras de seguir regras, o acordo para valores e normas não seria, no entanto, necessariamente o acordo quanto a aplicá-las.

Para Safatle a sociedade totalitária não é simplesmente organizada a partir da lei e do poder, mas é também a sociedade onde nunca se sabe de que maneira a lei será aplicada, cada um estará sempre à margem da lei, e a lei sempre será aplicada contra cada um. Safatle repisa a existência de uma "desagregação normativa fundamental na sociedade", o que poderia surgir inclusive como contradição à tendência de generalização dos dispositivos de segurança (e do Estado). "Nossas formas de vida ainda são bipolares, o poder não age quando impõe uma norma mas quando consegue impor um certo modo de descontentamento em relação à norma" - gerenciar as margens é a função do poder, "não impor a ordem mas gerenciar a desordem". 35

O discurso que conduz o público ao longo do espaço da Usina e das cenas do espetáculo é, em Miopia, um discurso que desdiz a si mesmo, um discurso cínico, portanto. Há na relação com o público o estabelecimento de uma racionalidade cínica em que as regras de condução e de manipulação dos corpos e dos olhares nunca estão claras, em que o púbico é instado a tomar decisões sem que haja um parâmetro para balizar tais atitudes. Em uma cena a condução se dará de maneira delicada, como se o público estivesse ali para contemplar; em outra cena o público é jogado no baú de um caminhão, como se fosse um dos desempregados desterrados.

No final da cena 7 de Miopia, as relações de assujeitamento do público mencionadas acima surgem de diferentes maneiras na fala da personagem Diotima:

DIOTIMA - Trazemos em nossas vidas a influência do povo negro (uma projeção da Escrava Zuzu hipnotiza e atrai os trabalhadores), que nunca perdeu a nobreza dos sentimentos, mesmo quando ainda eram escravizados. Quem se esquece da escrava que nos embalou? Que nos deu de mamar. Que nos deu de comer. Da negra velha que nos contou as primeiras histórias de bicho e de mal-assombrado. Da mulata que nos tirou o primeiro bicho-de-pé de uma coceira tão boa. Da escrava que nos iniciou no amor físico e nos transmitiu, no ranger da cama de vento, a primeira sensação completa de homem. Por isso aqui estamos para nos encantar com a Escrava Zuzu: a legítima representante do povo brasileiro, que está aqui para celebrar a harmonia dos povos, das classes e das raças neste imenso país! Depois de uma turnê de sucesso na Alemanha, na Itália e no Japão, a Escrava Zuzu aterrissa em São Paulo para nos encantar com sua sensibilidade, harmonia de proporções e simpatia! ( $O$ público é conduzido a um recinto fechado e escuro. Um baú de caminhão).

BELMIRO - É uma armadilha de Vargas! (As portas do

${ }^{35}$ Idem, p. 127. 
caminhão se fecham). ${ }^{36}$

Inicialmente, o público participa de um "showmício" em um dos pátios que dão acesso ao prédio da Usina, sendo bombardeado com dois shows simultâneos: a cantora Diotima exibe-se em um palco disposto no alto de um morro, enquanto do outro lado do pátio acompanhamos uma apresentação de dança da Escrava Zuzu, número que mistura elementos folclóricos e erótico-masoquistas.

Enquanto Diotima discursa, já no fim da cena, o público vai sendo empurrado, de maneira sutil mas constante, por policiais em direção a uma tela de projeção disposta no outro extremo do pátio. A projeção mostra o mesmo show de Zuzu, filmado ao vivo mas de um outro ponto de vista, distinto do que os espectadores acompanharam até então. O público vai sendo conduzido até a projeção, como se convidado a chegar mais perto, para ver melhor.

Quando o discurso de Diotima termina, o público é empurrado para detrás da tela de projeção, onde só então percebe um cômodo escuro, um baú de caminhão que é imediatamente fechado após a entrada do último espectador. Enclausurados no escuro, ouvem a frase de Belmiro e percebem-se ao lado dos personagens, vítimas de uma “armadilha de Vargas”. A sedução e o engano convivem ao lado da violência em uma mesma cena: ora o público é tratado como contemplador e juiz, participante de uma experiência estética desinteressada; ora essa mesma experiência, de tão brutal, torna quem assiste cúmplice da violência; ora as regras e a disciplina a ser cumprida surgem com clareza e violência; ora o controle exerce-se com uma aparente delicadeza.

Seria possível perguntar se as convocações de Antenor e de Diotima, bem como as de todos os personagens que em Miopia disciplinam e regem a condução do público durante a peça, poderiam revelar que, por trás desta fantasia de liberdade de escolha que caracteriza o discurso hegemônico da mercadoria, há regras que colocam o divíduoconsumidor distante da possibilidade de fazer escolhas. O que me parece importante ressaltar é que essa contradição entre práticas disciplinares e poderes de controle não foi conscientemente tematizada pelo grupo em seu processo de criação, emergindo apenas, no tecido final do espetáculo, dos detritos deste mesmo processo, da maneira disciplinar que tal processo foi conduzido pelos que dele participaram.

Se não estiver enganado, seria como se pudéssemos observar na peça esta contradição entre temáticas relacionadas à sociedade de controle encenadas de maneira

\footnotetext{
${ }^{36}$ ALMEIDA, Ligia Marina; DELMANTO, Ivan; FARIA, Fernanda et al.Miopia. Inédito, 2006, p. 5
} 
disciplinar, ou por outra, a convivência e complementariedade dentre estas diversas formas de assujeitamento, vindas à tona na peça por meio dos detritos do processo de ensaio.

O estudo do processo de ensaio de Miopia revela a importância, para a crítica teatral, da análise dos procedimentos empregados ao longo do processo de ensaio. Para usar um autor caro ao grupo durante os estudos dialéticos realizados para a construção da peça:

O consumo produz duplamente a produção. $1^{\circ}$. Somente pelo consumo o produto se torna realmente produto (...). A produção fornece ao consumo a sua matéria, o seu objeto. A produção cria, produz consumo. (...) $2^{\circ}$. Mas não é unicamente o objeto que a produção dá ao consumo. Dá-lhe ainda o seu aspecto determinado, o seu caráter, o seu acabamento. (...) A produção determina não só o objeto do consumo, mas também o modo de consumo, e não só de forma objetiva, mas também subjetiva. ${ }^{37}$

Esta identidade entre produção e consumo de que nos fala Marx pode ajudar-nos a perceber a presença do modo de produção empregado em Miopia, na teia formal do espetáculo. Ao assistir a peça, mediado pela forma, o público via-se diante dos vestígios, das ruínas deste processo de ensaio. Se é verdade que tal processo não pode ser lido e compreendido de maneira imediata, é função da crítica desvelá-lo, utilizando outra expressão empregada por Marx, como se visto por uma câmera invertida: o processo de criação, e o seu modo de produção correspondente, surgiriam assim de maneira oblíqua, como um negativo fotográfico, cabendo ao trabalho crítico "colocar a forma sob seus pés." Nos capítulos seguintes, esta relação entre diário de trabalho e obra artística, entre o objeto e seu processo de criação, será sempre um dos focos de nossa investigação.

\section{I.2. Constelação, controle e lixo}

A forma apresentada ao público em Miopia procurou ser sempre uma espécie de ensaio em perpétuo devir. Isto porque o grupo procurou romper com a forma mercadoria, não só nas apresentações, todas gratuitas, mas também com relação ao conceito de produto. Assim, as apresentações constituíram-se sempre por meio de um

\footnotetext{
${ }^{37}$ MARX, Karl. Contribuição à crítica da economia política. São Paulo: Martins Fontes, 2000, p. 236237.
} 
formato aberto, que buscava na relação com o público estabelecer um processo coletivo de criação em movimento.

Mesmo com a temporada em andamento, o grupo manteve e aumentou o seu cronograma de ensaios, para poder transformar a cada final de semana o ensaio em devir a ser apresentado. Por isso, ao final do projeto, foram realizadas versões tão diversas de Miopia que podemos considerá-las quase como obras teatrais distintas, ou, talvez com mais exatidão, momentos sucessivos de um mesmo processo em movimento contínuo, devir que dissolveria o conceito de obra artística para instaurar a ideia de percurso de criação.

Nesse sentido, o espetáculo estabelecia com seu espectador uma experiência crítica de teor distinto das referências basilares da pesquisa inicialmente empreendida pelo grupo durante o seu processo criativo (vide, a este respeito, a proposta de Brecht que previa, na relação com o público, o estabelecimento daquela "ânsia de conhecimento" e de revelação da verdade, por trás das cortinas da ideologia, de que falamos anteriormente). Além de uma racionalidade cínica, que se estabelecia na relação com o público, que não sabia nunca quais as regras do jogo e as leis a que estava submetido, os artistas e seu público estavam lidando com uma tentativa de experiência coletiva.

Para Walter Benjamin, assim como foi privado de sua biografia, o ser humano sob o capital foi expropriado também de sua capacidade de viver e de transmitir experiências. O filósofo alemão, que já em 1933 havia diagnosticado com precisão a pobreza de experiência da época moderna, indicava suas causas na catástrofe da guerra mundial, de cujos campos de batalha "a gente voltava emudecida (...) não mais rica, porém mais pobre de experiências partilháveis".

No entanto, hoje seria possível dizer que, para a destruição da experiência, uma catástrofe não é de modo algum necessária, e que a pacífica existência cotidiana em uma grande cidade seria, para esse fim, perfeitamente suficiente, pois o dia a dia contemporâneo não conteria quase nada traduzível em experiência. Essa expropriação da experiência estaria ligada aos ditames da razão administrada e da ciência tecnicizada. Em um fragmento em que o filósofo Francis Bacon distingue, no século XVIII, experiência de experimento, pode haver pistas importantes sobre a itinerância e o vagar do público em Miopia:

A experiência, se ocorre espontaneamente, chama-se acaso, se deliberadamente buscada recebe o nome de experimento. Mas a 
experiência comum não é mais que uma vassoura desmantelada, um proceder tateante como o de quem perambulasse à noite na esperança de atinar com a estrada certa, enquanto seria mais útil e prudente esperar pelo dia ou acender um lume, e só então pôr-se a caminho. A verdadeira ordem da experiência começa por acender o lume; com este, em seguida, aclara o caminho, iniciando pela experiência bem disposta e ponderada, que chamamos de experimento, e não por aquela descontínua e às avessas, primeiro deduz os axiomas e depois procede a novos experimentos. ${ }^{38}$

Esta "vassoura desmantelada", este "proceder tateante de quem perambulasse à noite na esperança de atinar com a estrada certa" talvez represente percurso de criação do espetáculo e se reproduza no caminho percorrido pelo público:

Assim, não estávamos realizando um experimento com resultados previstos e dedutíveis e que podia ser repetido a qualquer momento, sob as mesmas condições de temperatura e pressão. Estávamos todo o tempo caminhando sem lume e tal percurso constituiu uma tentativa coletiva de se chegar a lugares não previstos nos mapas da sociedade do espetáculo, gravando o percurso de nossos rastros em nossos corpos e mentes. Este tatear coletivo em busca de esperança era a nossa experiência como artistas, e foi o que pudemos oferecer ao público, a cada noite que este se dispunha caminhar. ${ }^{39}$

Caberia perguntar se tal forma tem realmente a capacidade de gerar qualquer experiência coletiva, ou mais além, se a proposta de conduzir o público por este percurso de controle disciplinar exercido de maneira cínica não é, ela mesma, mimetismo da forma mercadoria em seu estágio contemporâneo.

Em seu estudo sobre a trajetória do McDonald's, Isleide Fontenelle argumenta que, já no início da década de 90 do século XX, as grandes marcas mundializadas constataram uma crise de valor em suas imagens. A antiga capacidade das marcas publicitárias de conferir credibilidade e demais valores sociais agregados aos seus produtos estaria em declínio, já que as pesquisas demonstravam uma incapacidade do consumidor em distinguir, guiado pelas marcas, quais produtos concorrentes escolher. As imagens pareciam indiferenciar-se no mercado fantasmático universal.

Para a autora, a partir deste momento as estratégias de marketing deslocaram-se do consumo da imagem para oferecer o consumo de experiências. As lojas da cafeteria Starbucks seriam o novo paradigma deste deslocamento por oferecerem ao consumidor, para além de um café saboroso e de uma imagem reconhecida, a experiência de um

\footnotetext{
${ }^{38}$ BACON, Francis. Ensaios. Lisboa: Guimarães Editores, 1992, p. 173.

${ }^{39}$ ALMEIDA, Ligia Marina; FARIA, Fernanda; DELMANTO, Ivan, et al. Miopia - programa do espetáculo. Inédito, 2006, p. 3.
} 
ambiente tranquilo, cuidadosamente decorado para se promover uma experiência de idílio nostálgico, de mergulho em uma temporalidade lenta e em um espaço aconchegante, próximo ao interior burguês do século XIX de que nos fala Walter Benjamin, "em que o burguês tinha no seu quarto a mesma sensação de um produto em seu estojo".

Wolfgang Fritz Haug também menciona a estética da mercadoria não mais apenas sob os encantamentos da imagem:

Expor e apresentar as mercadorias; decoração do ponto de vendas, sua arquitetura, a iluminação, as cores, o fundo musical, os aromas; a equipe de venda - cada momento de mudança de forma da mercadoria e as circunstâncias nas quais ocorre e que o influenciam são abrangidos pelo cálculo fundamental da valorização e configurados funcionalmente. (...) A propaganda do capital para a construção de lojas fala num tom ameaçador: "Quem quiser vender, tem de oferecer experiências". ${ }^{40}$

Se a comercialização de experiências é a estratégia mais recente de sedução empregada pela venda de mercadorias, o que significaria a condução cínica do público por entre os becos e passagens escuras de uma usina de lixo, o que significa fazer do público um criador constante da obra? Esta estratégia de constituir-se como obra aberta, moldável infinitamente aos desejos do consumidor, não é a estratégia da forma mercadoria em seu estágio mais emblemático, presente na internet, com suas plataformas de códigos abertos; nos games, com sua aparente interatividade; e nos sanduíches do McDonald's e do Burger King, por exemplo, com suas infinitas variações colocadas a critério do consumidor faminto? A crítica de Miopia não nos obrigaria, assim, a ler nessa espécie de encruzilhada histórica o envelhecimento dos procedimentos artísticos tanto do modernismo quanto das vanguardas?

O 'experimento' como conceito estético há muito entrou no vocabulário da indústria da consciência. (...) Um experimento só faz sentido quando as variáveis que surgem são conhecidas e podem ser delimitadas. Outra condição: cada experimento precisa ser comprovável e na sua repetição levar a um só e conhecido resultado. (...) Quadros, poemas, apresentações não cumprem essas condições. O experimento é um processo para produzir conhecimentos científicos, não para a produção de arte. (...) O blefe experimental coqueteia com o método científico e suas exigências, mas não pensa em se relacionar com ele seriamente. É 'ação pura' sem quaisquer pressupostos. (...) Quanto mais se afastam de qualquer experiência prática, tanto mais 'experimentais' são os

\footnotetext{
${ }^{40}$ HAUG, Wolfgang Fritz. Crítica da estética da mercadoria. São Paulo: Fundação Editora da UNESP, 1998, p. 100-101.
} 
experimentos da Vanguarda. ${ }^{41}$

Vista sob este aspecto, um retorno à noção modernista de obra acabada e de contemplação refletida da obra (aspectos tão claramente presentes na estética de Brecht, por exemplo) não seriam procedimentos críticos mais capazes de gerar esta experiência artística mobilizadora e desestabilizante a que o coletivo de autores de Miopia se propunha?

Se por um lado, o rigor e disciplina presentes no processo de construção de Miopia deram ao espetáculo sua feição modernista de obra, distanciando-o da ação pura do experimento, de que nos fala acima Enzensberger, a utilização constante do procedimento da montagem e a transformação constante do espetáculo, com ensaios contínuos durante a temporada - gerando sucessivas versões da encenação -, aproxima a peça do território das vanguardas históricas:

\begin{abstract}
A "obra", o "trabalho", como uma estrutura racional está no âmago do modernismo. Assim torna-se mais próximo do conceito clássico de arte do que indicado pelas declarações explícitas de seus portavozes. A ênfase sobre a racionalidade do processo criativo e a atitude reservada, se não excludente, quanto a "expressão", opõe o modernismo ao romantismo e indica novamente uma proximidade oculta entre o classicismo e o modernismo. Naturalmente, Valéry excluiu a possibilidade de completar um trabalho. Essa crença não se apoiava numa admiração romântica pelo fragmentário, mas preferivelmente por sua confiança na força dos procedimentos artísticos racionais. $^{42}$
\end{abstract}

Se a noção de obra, com seu acabamento tradicional, não pode ser empregada na crítica de Miopia, também não podemos utilizar conceitos característicos da vanguarda para descrever a peça:

A ação "dada" dos surrealistas e a écriture automatique são exemplos de uma prática vanguardista que se diferencia do modernismo ao negar ainda categorias estéticas válidas. Isto é especialmente verdadeiro para "trabalho". Como marca da écriture automatique, a auto-expressão do escritor tende a negar o trabalho. E, ao mesmo tempo, no entanto, a escolha racional entre vários meios é eliminada. A écriture automatique não aprova o princípio do refus e, sim, a espontaneidade da expressão. ${ }^{43}$

Não há autoexpressão em Miopia. O processo criativo inteiro foi conduzido sob o

\footnotetext{
${ }^{41}$ ENZENSBERGER, Hans Magnus. As aporias da Vanguarda. In: Com raiva e paciência: ensaios sobre literatura, politica e colonialismo. São Paulo: Paz e Terra, 1985, p. 69-70.

${ }^{42}$ BÜRGER, Peter. O Antivanguardismo de Adorno. Tradução de Newton Ramos de Oliveira, Faculdade de Ciências e Letras da UNESP (Publicação interna). In:

http://antivalor.atspace.com/Frankfurt/burger.htm. Consultado em 12/10/10.

${ }^{43}$ Idem, ibd.
} 
trabalho constante por uma estrutura racional capaz de expressar um conceito de encenação. A concepção de direção teatral que norteou o processo de criação distanciase do papel legado ao diretor ao longo da tradição do teatro, absolutamente textocêntrica. Para esta concepção, o diretor funcionaria como mero representante das palavras do dramaturgo e sua criação consistiria na fidelidade em representar o texto, como um advogado defende os autos. Em Miopia, com texto e cena sendo criados simultaneamente, a partir de improvisações, o texto literário confundia-se o tempo todo com o roteiro de encenação: os diálogos já nasciam acompanhados de rubricas, que na verdade registravam ou recriavam o que já havia sido executado em cena pelos atores.

Em tal processo, o que caracteriza a dimensão teatral, ao contrário da literatura dramatúrgica, é a materialidade cênica. A partir de Stanislavski, o diretor teatral deixa de ser visto apenas como um gestor, um distribuidor de papéis e um representante do dramaturgo em sala de ensaio, e passa a ser visto como "encenador", a saber, o criador responsável, através de uma relação de aproximação e de negação do texto, por transformar ideias e conceitos, mais do que apenas as palavras do material literário, em ações, imagens, símbolos ou alegorias, dando à transformação do texto um ponto de vista muitas vezes distinto do original:

O texto, no caso, se funde completamente com a expressividade da
voz do ator (o que implica dados individuais de inflexão, ritmo,
dinâmica, intervalos, timbre etc.) e, ainda, com a expressividade
visual de movimento, gesto, mímica formando com todos esses
momentos (e ainda com a cenografia, os figurinos, a iluminação
etc.) uma totalidade nova, indivisível. Todos esses dados não são
"marginais": junto com o texto formam uma nova unidade que,
precisamente como tal, "encontra a sua realidade completa" na
alma do espectador. ${ }^{44}$

Assim, a encenação, tal como experimentada em Miopia, pode ser encarada como a relação de todos os sistemas significantes do espetáculo. Tal encenação não poderia ser encarada como uma reunião incoerente dos materiais, mas seria definida, pelo contrário, como objeto de conhecimento, o sistema de relações que tanto a produção (os atores, o encenador, a cena em geral), quanto a recepção (os espectadores) estabelecem entre os materiais cênicos a partir daí constituídos por sistemas significantes.

A encenação em Miopia não seria uma translação do texto para a cena, mas sim um teste teórico, conceitual, que consistiria em colocar o texto sob tensão, a fim de experimentar no que é que a enunciação cênica provoca o texto; abrindo-o para muitas

${ }^{44}$ ROSENFELD, Anatol. Prismas do teatro. São Paulo: Perspectiva, 1993, p. 237-242. 
interpretações possíveis. A encenação torna-se hipótese sobre uma enunciação que resulta, sem cessar, na concretização de enunciados novos; tal encenação sempre está para acontecer, visto que se limita a colocar balizamentos, a dispor o texto em função de uma enunciação e a dar a conhecer suas intenções. Veremos adiante que tal intencionalidade das dramaturgias que compõem a cena de Miopia abre possibilidades para uma modalidade de encenação que desmente o texto, contradizendo-o, valorizando o combate entre o texto e a cena:

É a representação teatral: como representação dentre as práticas irredutíveis uma a outra, e muito menos conjugadas, como momento em que ambas se afrontam e se interrogam; como combate mútuo em que o espectador é, no final das contas, o juiz e a aposta, sendo que é preciso, a partir disso, tentar pensar. O texto, todos os textos, têm o seu lugar. Nem o primeiro, nem o último: o lugar do escrito e do permanente num evento concreto e efêmero. Este confronto mencionado está, pelo menos, longe de acabar. ${ }^{45}$

Assim, a encenação de Miopia não seria uma concretização-ficcionalização como qualquer leitura de um texto escrito; seria uma pesquisa de enunciados cênicos que produzem uma escritura cênica global, dentro da qual o texto teatral adquire um sentido bem específico. Do mesmo modo, salvo engano, não ocorre nesta encenação nada parecido a um agrupamento aleatório de sistemas visuais construídos sobre o texto; mas um projeto coletivo realizado em torno de um constrangimento da linguagem, que gera, como detritos desse combate, uma estrutura de encenação arruinada, composta de estilhaços múltiplos. $^{46}$

É possível acompanhar o processo de construção desse conceito de encenação presente em Miopia, lendo um trecho de um dos relatórios de pesquisa apresentados pelo grupo à Secretaria de Cultura:

A questão central para a elaboração de um projeto de encenação é a de como transformar as questões centrais do trabalho, conceituais, em símbolo cênico, em imagem.

A primeira imagem que nos surgiu foi a do sonho, da cidade dos sonhos. Ainda de forma abstrata, um dos primeiros caminhos explorados pela encenação foi o da lógica dos sonhos, do inconsciente colonizado, do sonho mercadoria.

A segunda imagem que surgiu, junto com a criação da dramaturgia, foi a do cinema, antecipando o império contemporâneo da imagem, névoa que encobre a contradição central entre capital e trabalho, feita de matéria, lixo, sangue e pus coagulados por séculos, e não da beleza etérea e colorida das imagens cotidianas. $\mathrm{O}$ cinema aqui

\footnotetext{
${ }^{45}$ DORT, Bernard. Le texte et la scene: pour une nouvelle alliance. In: http://www.universalis.fr/encyclopedie/bernard-dort/. Consultado em 11/09/10.

${ }^{46}$ PAVIS, Patrice. O teatro no cruzamento de culturas. São Paulo: Perspectiva, 2009, p. 28.
} 
como símbolo de uma realidade que só se reproduz enquanto ilusão. Um mundo hipnose. A cidade que precisa ser hipnotizada para viver.

A terceira imagem que surgiu foi a da peste. A cidade doença, criando um cenário de deserto, do deserto do real.

Mas até aqui ainda estávamos trabalhando no plano do conceito: sonho/delírio, cinema/ilusão, doença/catástrofe. Como então concretizar estes símbolos em imagens e material cênico?

Como retratar, por exemplo, a metamorfose do trabalho, que passa agora a reproduzir-se e criar valor enquanto imagem, saindo da fábrica para o espetáculo?

O primeiro procedimento sistematizado, capaz de unir todos estes conceitos e imagens, foi a investigação sobre o delírio. A encenação, o texto e a construção dos personagens a partir da lógica do delírio. Imagens de delírio. Sons do delírio. A realidade da imagem, do trabalho e da mercadoria como a realidade do delírio (fantasmagoria).

A estrutura espelhada da Usina de Lixo (em que um espaço espelha outro, arquitetonicamente, em que máquina espelha máquina) reflete a estrutura espelhada do texto: contraponto de diversos narradores, história que narra a imagem e o seu reflexo especular, a mercadoria.

Seguindo este labirinto de espelhos, há na estrutura da peça a Colmeia das Imagens (um cinema só de comerciais) e a Colmeia da Memória (um foco de resistência política fracassada). É como se cada momento fosse encenado com o seu duplo contraditório ${ }^{47}$.

A encenação em Miopia pode ser vista como uma parábola sobre a permuta impossível entre o verbal e o não-verbal: o não-verbal faz falar o verbal, reitera a enunciação e a desmente, como se o texto teatral, uma vez emitido em cena, conseguisse falar por si mesmo através da contradição entre aquilo que é dito e aquilo que é mostrado.

Seria possível perceber, no relato acima, o quanto minha reflexão sobre o processo de criação ainda estava contaminada por uma intenção inicial de harmonizar texto e cena, verbal e não-verbal. É como se naquele momento a minha visão como encenador estivesse marcada ainda por um certo textocentrismo, em que os elementos da cena surgiriam todos atrelados ao texto ("a estrutura espelhada da Usina reflete a estrutura espelhada do texto"). No entanto, tal declaração de princípios é negada pela realização do espetáculo em que - apesar da manutenção das imagens do espelhamento,

\footnotetext{
${ }^{47}$ DELMANTO, Ivan. "Em busca de um conceito de encenação". ALMEIDA, Ligia Marina; FARIA, Fernanda; DELMANTO, Ivan, et al. Anjos do desespero. Relatório da terceira etapa de pesquisa. Apresentado à Secretaria de Cultura do Município de São Paulo, 2006, p.7. Inédito. Disponível para consulta na Divisão de Fomento da Secretaria Municipal de Cultura.
} 
da peste e da lógica do delírio como integrantes da escrita espetacular - há um antagonismo entre texto e encenação.

A presença dos conceitos de delírio, peste e espelhamento na composição da escritura cênica, bem como sua relação contraditória com o texto podem ser identificadas se prosseguirmos com a leitura da segunda cena da peça:

\section{IMAGEM DA REVOLUÇÃO}

Belmiro, em frente a um outdoor, no alto da torre da caixa d'água. Manipula um boneco, ricamente vestido, que tem o seu rosto. Depois entra Rosa - que se desprendera da grande teia de fitas de isolamento - distribuindo manifestos.

BELMIRO - Eu não quero ser mais eu.

ROSA - Que roupa ridícula é essa, Belmiro?

BELMIRO - Sou eu. Eu sou aquilo que sou.

ROSA - Eu quero com a fantasia do Exército Vermelho, de revolucionário. Me excita. Vamos, anda, se troca e me excita!

BELMIRO - Agora não. Não ser eu me excita. (Aponta o outdoor $e$ se masturba. Rosa joga o boneco e também se masturba olhando o

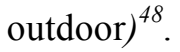

Belmiro e Rosa, neste momento da peça, são militantes do Partido Comunista Brasileiro. O texto apresenta um encontro amoroso do casal, em que a relação sexual só se efetivaria se a fantasia de Rosa se concretizasse. A cena foi criada a partir de improvisações dos atores que procuraram expor a reificação colonizando as subjetividades e os afetos, independente da atuação política do casal. Esta primeira camada da cena, presente no texto, tem sentido bastante óbvio e direto. As rubricas, no entanto, foram compostas posteriormente, já durante a composição da encenação; tal composição dilui o que seria a ação central do texto - conservando-a como sombra e fantasma - e apresenta outros elementos cênicos, capazes de deslocar completamente o sentido original.

A cena foi realizada fora do edifício da Usina, na caixa d'água central, uma torre de quase vinte metros de altura. Logo acima do chão, à cerca de dois metros de altura, Rosa estava posicionada em um parapeito e durante a cena saía e entrava por uma porta de ferro. Belmiro foi posicionado quinze metros acima, em um segundo parapeito, quase no topo da torre. Assim, durante a cena, os dois personagens não se viam, e falavam olhando o amplo horizonte do pátio da Usina, vazio à sua frente. Acima de Belmiro, quase como uma divindade, havia um outdoor luminoso, anunciando o

\footnotetext{
${ }^{48}$ ALMEIDA, Ligia Marina; DELMANTO, Ivan; FARIA, Fernanda, et al. Miopia. Inédito, 2006, p. 1
} 
espetáculo Miopia.

Enquanto diziam o texto, os dois atores trabalharam a partir do seguinte registro de atuação: a contaminação pela peste das imagens. A peste, evento narrativo que só surgiria ao público nas cenas subsequentes, aqui já teria contaminado os dois personagens. Após exercícios para construir corporalmente o que seriam estes sintomas da peste das imagens, optamos por trabalhar a partir da imagem do cadáver: o olhar dos atores nunca estaria focado e seus corpos procurariam mover-se a partir do seguinte exercício: "Explore movimentos como se o seu corpo estivesse empalhado. Seu corpo move-se em pedaços" 49 .

Esse corpo morto contradizia a excitação do ato sexual, presente no texto. E a única ação executada em cena, realizada por Belmiro, acontecia na chave do delírio: o personagem recusava o jogo proposto por Rosa e masturbava-se olhando e tocando o outdoor acima de si. A imagem do cartaz da peça, transformada em luminoso, era o único estímulo capaz de mobilizar o personagem, contaminando-o.

O fato da imagem escolhida ser a do próprio espetáculo, mais do que metalinguagem, propunha também o seu inevitável fracasso, propondo ao espectador que qualquer obra artística, independentemente de suas intenções políticas, em tempos presentes, emergiria também colonizada pela forma mercadoria. Sob o gozo de Belmiro, Rosa o imitava, espelhando-o na busca por prazer. No final da cena, os dois parecem gozar e parecem sofrer, entre gritos, gemidos e sons incompreensíveis - quase uma língua incompleta que apenas desejasse circularmente -, que permanecem mesmo enquanto o público é deslocado para a cena seguinte.

Há na cena, portanto, um triplo espelhar: Belmiro veste-se como um boneco e o imita, enquanto Rosa reproduz Belmiro. Este espelhamento constante apresenta-nos, salvo engano, o reflexo refletindo-se a si próprio, em uma estrutura que talvez distanciese do espelhamento mencionado acima e aproxime-se da ideia de simulacro:

Hoje a abstração já não é a do mapa, do duplo, do espelho ou do conceito. A simulação já não é simulação de um território, de um ser referencial, de uma substância. É a geração pelos modelos de um real sem origem nem realidade; hiper-real. O território já não precede o mapa, nem lhe sobrevive. É agora o mapa que precede o território - precessão dos simulacros - é ele que engendra o território cujos fragmentos apodrecem lentamente sobre a extensão do mapa. É o real, e não o mapa cujos vestígios subsistem aqui e ali, nos desertos que já não são os do Império, mas o nosso. $O$

${ }^{49}$ DELMANTO, Ivan. Caderno de direção. Inédito, 2006, p. 23. 
deserto do próprio real. ${ }^{50}$

Para Baudrillard, o simulacro é uma imagem não mais passível de ser trocada pelo seu equivalente real, mas trocando-se em si mesma, em um circuito ininterrupto cujas referência e circunferência encontram-se em lado nenhum. Na cena acima, que é real e que é a cópia? Quem imita quem? Descrevendo a Disneylândia, Baudrillard aponta que neste parque temático "o mundo quer fazer-se infantil para esconder que a verdadeira infantilidade está em toda parte".

O boneco que replica Belmiro, ou Belmiro que replica o Boneco, ou Rosa que replica Belmiro, ou Belmiro que replica Rosa: este trânsito constante de cópias talvez proponha a subjetividade destes personagens como um simulacro: tentam ser o Outro ${ }^{51}$, talvez para esconder que a alteridade permaneça como simulacro em seu mundo. A própria busca pelo gozo converte-se, nos dois personagens, em algo que o psicanalista Charles Melman caracteriza como:

Estamos passando por uma mutação que nos faz passar de uma economia organizada pelo recalque a uma economia organizada pela exibição do gozo. Não é mais Possível hoje abrir uma revista, admirar personagens ou heróis de nossa sociedade sem que eles estejam marcados pelo estado específico de uma exibição do gozo. $^{52}$

A imagem dos dois personagens pendurados no alto da caixa d'água, exibindo em público a sua busca pelo gozo, remete à definição elaborada por Melman para descrever a subjetividade contemporânea: "o homem sem gravidade". Apesar da felicidade que se supõe que a nova economia psíquica (que internalizou o mercado) assegura, a ausência de gravidade lembra sempre ao sujeito que, em algum lugar, há um impossível, que há sempre, em algum lugar, algo dependurado prestes a despencar.

Segundo Patrice Pavis, pelo fato de a encenação dizer ao mostrar, ela diz sem dizer, de sorte que a denegação (a Verneinung freudiana ${ }^{53}$ ) é o seu modo de existência

\footnotetext{
${ }^{50}$ BAUDRILLARD, Jean. Simulacros e simulação. Lisboa: Relógio d'água, s/d, p. 8

${ }^{51}$ Lacan escreve Outro, com maiúscula, para distingui-lo do parceiro. Trata-se, então, de um lugar, que em particular é o lugar da linguagem, o lugar dos significantes, situado para além de qualquer pessoa e onde se situa o que é anterior ao sujeito e que, entretanto, o determina. Segundo Zizek: "É qual Outro que o homem deseja" o primeiro significa que o desejo é estruturado pelo "descentrado" grande Outro, a ordem simbólica: o que eu desejo é predeterminado pelo grande Outro, o espaço simbólico no qual eu habito. Mesmo quando os meus desejos são transgressivos, mesmo quando eles violam as normas sociais, essa transgressão é muito condicionada por aquilo que transgride."'(ZIZEK, Slavoj, "Lacan com de Olhos bem fechados". In: Como ler Lacan. Rio de Janeiro: Zahar, 2010, p. 55).

${ }_{52}$ MELMAN, Charles. O homem sem gravidade. Rio de Janeiro: Companhia de Freud, 2008, p. 16.

${ }^{53}$ Denegação tem, aqui, um sentido que remete a uma não aceitação, a uma recusa daquilo que emerge na
} 
habitual. Ao dizer sem dizer, “[...] a encenação instaura como que uma denegação: diz sem dizer, fala do texto graças a um sistema semiótico distinto que não é linguístico, mas icônico." 54

O conceito de encenação seria assim responsável por estabelecer aquilo que Patrice Pavis chama de "equilíbrio delicado entre a visibilidade e a invisibilidade da encenação como sistema de sentido". De acordo com esta definição, para que uma encenação seja perceptível, seria preciso que o espectador apreendesse o conceito que a anima, mesmo se não fosse capaz de entender o sentido do texto. Este conceito deve ser tornado visível de uma maneira ou de outra; caso o espectador não o perceba, ele terá a impressão de que não viu uma encenação, mas que viu cenas acontecerem, sem que a partir desta sucessão fosse capaz de perceber a coerência, a unidade da construção espetacular. Inversamente, se o conceito é tornado muito visível pelo fato de ser simplista, rudimentar ou porque se exibe em demasia, teríamos pela frente uma obra com um sistema linear e fechado, de sentido único.

Se sob um ponto de vista Miopia apresenta-se como encenação construída a partir da polissemia de distintas dramaturgias, organizadas sob um conceito de encenação que procura organizar o espetáculo como esta unidade de construção que mencionamos acima, por outro lado é possível perceber na peça características típicas da vanguarda:

\begin{abstract}
A recepção da obra de arte pelos movimentos vanguardistas não se opõe totalmente ao modernismo, mas, em vez disso, radicaliza uma tendência já implícita nele. As obras modernas frequentemente também pretendiam chocar o receptor. Esta, no entanto, é apenas uma primeira reação, que será seguida pela contemplação da obra. Mas, ao contrário, as manifestações dadas não admitem esta contemplação, mas tentam intensificar de maneira imediata a atitude do receptor. ${ }^{55}$
\end{abstract}

instância do Outro. Para Freud, é a constituição do sujeito no campo do Outro. O "não" do paciente não nega o que foi dito, mas assinala a incompletude da construção: "não foi dito tudo". Por uma questão de estrutura, "tudo" não pode ser dito: não há palavras para dizer tudo, ou o nem tudo é recoberto pelo simbólico: algo falha, rateia, escapa, faz resto. (FREUD, Sigmund. "A negativa", Ed. Standard Brasileira das Obras Psicológicas Completas, Vol. XIX, Rio de Janeiro, Imago, 1976, p. 293-300.).

A denegação seria uma via de acesso do recalcado à consciência. Como diz Freud, a denegação é uma aufhebung do recalque, que evidencia a separação entre a função intelectual e o processo afetivo. "Isso porque a negativa [Verneinung] é uma maneira de tomar conhecimento do recalcado em seu plano apenas intelectual. O que está em jogo, nesse caso, é só uma suspensão do recalque, naturalmente ainda não sua plena aceitação [...]. Na verdade, com a negativa, somente um dos resultados do processo de recalque é revertido: aquele que impede que o conteúdo da ideia alcance a consciência. Disso resulta, então, uma aceitação apenas intelectual do recalcado, o essencial do recalque permanece intocado." (FREUD, 1976).

${ }^{54}$ PAVIS, Patrice, op. cit., p. 28

${ }^{55}$ BÜRGER, Peter. O Antivanguardismo de Adorno. Tradução de Newton Ramos de Oliveira, Faculdade de Ciências e Letras da UNESP (Publicação interna). In:

http://antivalor.atspace.com/Frankfurt/burger.htm. Consultado em 12/10/10. 
Ou, por outra:

Em "A obra de arte na era da reprodutibilidade", Benjamin criticou um conceito tradicional de arte aurática. A aura pode ser comparada à atitude de um crente relativa a objetos de culto religioso. Segundo Benjamin, no século XX há uma perda da aura. Mais importante do que a explicação tradicional desta perda, que Benjamin fornece em termos da psicologia da recepção, é a relação entre uma perda da aura e a técnica vanguardista de inserir fragmentos desprezados de vida cotidiana na obra de arte. Ao compor poemas a partir de fragmentos da linguagem e ao montar botões ou tickets em pintura, o dadaísta alcança "uma desrespeitosa destruição da aura de sua criação” Diríamos, hoje, que eles pretendiam a destruição da aura. Assim, o vanguardismo desafiou as categorias centrais da estética idealista que ainda são aceitos pelo modernismo: a ideia de uma obra em que todas as partes são formadas e em que a forma e o conteúdo constituem uma unidade imediata. A contemplação pressupõe uma recepção da obra de acordo com o modelo idealista da unidade de sujeito e objeto. ${ }^{56}$

A montagem, procedimento que marca toda a reflexão de Benjamin e de Bürger sobre a vanguarda, surge em Miopia de inúmeros modos: colagem de diversos narradores na constelação presente no texto, dos elementos visuais distintos, retirados do lixo e das ruínas da própria Usina (refletores construídos com latas, tochas utilizadas como luzes, pedaços de portas como cenários, figurinos costurados com farrapos). Em Miopia, o perambular do público pelos espaços abandonados da Usina de lixo, é o perambular pela cena abandonada da peça, encenação construída de detritos, que interrompe de tal modo o suceder do texto que, mais do que personagens, percebe-se a aproximação e a distância de figuras anônimas que abordam o público a todo instante, murmurando algumas palavras endereçadas não se sabe a quem: pedaços de texto são perceptíveis, sem que se possa reconhecer ou montar qualquer história ou fábula, mesmo contando com um texto que propõe uma narrativa, organizada de maneira não linear. Mais do que a encenação de um material textual pré-existente, melhor seria falarmos de uma instalação visível à distância e, assim, não visitável a qualquer momento e não visível sob todos os ângulos.

Essa instalação insere-se em um espaço/tempo comum no qual o público penetra em conjunto, sob o comando dos atores. Na prática, tal público distinguia níveis diferentes de elementos amontoados, superpostos, sucessivos e deslocados, dados num "imbricamento" ou dispersos configurando, em tal diversidade, a unidade do conceito

\footnotetext{
${ }^{56}$ Idem, ibd.
} 
de encenação. O espectador seria assim constrangido incessantemente a trilhar e religar suas próprias percepções, sem saber se a partilhava com os outros. Sua tarefa consistiria essencialmente em aceitar sensações visuais e auditivas novas, colocadas em comum por uma comunidade frágil e efêmera. Podemos afirmar sobre Miopia algo próximo à descrição que Patrice Pavis faz do espetáculo Coda, do grupo francês Théatre du Radeau:

No lugar do único olhar do encenador vetorizando, encontram-se esses materiais, um conjunto de imagens e sons dados como uma coralidade, àquelas de todos os elementos da representação considerados sem hierarquia pré-estabelecida. Essa coralidade não partilha a palavra: religa acontecimentos cênicos e inaugura uma nova maneira de estar no mundo e de recebê-lo em conjunto. Os materiais, textos, sonoridades, luzes, silhuetas, são desdobrados, estendidos diante de nós, mantidos à distância, único índice que ainda distingue a visão teatral e a instalação. Somos confrontados com um "excesso de significação", com um "significante voador", e esta superabundância de significante, seu caráter suplementar, mantém assim uma finitude, isto é, uma falta que deve ser suplementada. ${ }^{57}$

Esta coralidade da encenação surge em Miopia como acúmulo de destroços, de elementos inacabados em seu desgaste e em sua descartabilidade. A presença desta abundância do significante expressaria, em Miopia, uma perda geral de sentido? O percurso errante do público pela Usina, bombardeado por imagens, ruídos e farrapos de texto desorganizados representaria um vazio absoluto de possibilidade de interpretação e de cognição? Prefiro pensar que, pelo contrário, em Miopia a escritura cênica apresenta-nos como conceito um significante em constante desequilíbrio: os sentidos apresentados pelas cenas despedaçadas não remetem a um significado anterior e estável, mas inventam-se nas suas perpétuas mutações.

No capítulo sobre o fantasmagórico em seu livro sobre Wagner, Adorno critica como caráter fantasmagórico nas óperas do músico alemão o "ocultar sua criação pela aparência do produto" ${ }^{, 58}$. As obras de arte participam do fantasmagórico na medida em que estão apagados todos os traços de sua criação. Assim, aparecem como realidade que se contém a si mesma - uma realidade de ordem superior. Em Miopia, a encenação exibe suas cicatrizes e tais marcas são as fraturas do próprio processo de criação da obra, que permanece exposto e não procura camuflar-se sob a aparência de produto.

\footnotetext{
${ }^{57}$ PAVIS, Patrice. A encenação contemporânea. São Paulo: Perspectiva, 2010, p. 213.

${ }^{58}$ ADORNO, Theodor. Monografias Musicales. Madri: Ediciones Akal, 2008, p. 82.
} 
No entanto, tal exposição do processo de trabalho não foi organizada conscientemente pelos criadores, mas ganhou configuração na medida em que a forma épica escolhida para tratar dos conteúdos pesquisados mostrou-se incapaz de configurar o espetáculo. A incapacidade dessa forma épica é exposta em cena como um despojo de guerra, e a permanência do seu cadáver, dos seus destroços, caracteriza a espécie de forma lixo presente em Miopia.

Tal contradição é bastante visível se tomarmos como exemplo novamente o percurso do público em vagar itinerante ao longo da peça: o número de espaços distintos percorridos no interior da Usina era tamanho - e cada espaço apresentando tal número de imagens e sonoridades diversas - que o desenrolar da narrativa proposta pelo texto foi totalmente estilhaçado pelas constantes interrupções e movimentações a que era submetido o público, além de tudo constantemente assaltado por inúmeras imagens, tais como as presentes na rubrica da segunda cena da peça, já citada acima:

\section{IMAGEM DA REVOLUÇÃO}

Belmiro, em frente a um outdoor, no alto da torre da caixa d'água. Manipula um boneco, ricamente vestido, que tem o seu rosto. Depois entra Rosa - que se desprende da grande teia de fitas de isolamento - distribuindo manifestos. ${ }^{59}$

Mal terminada a primeira cena da peça, em que o público - após descer de um ônibus que o transportara, através de uma viela estreita, ao alto da Usina - assistira a um dos personagens balbuciando pedaços de um texto presa em uma teia de fitas de isolamento (com dez metros de diâmetro), o espectador desloca-se ao pé de uma altíssima torre em que as imagens expostas acima são bombardeadas. Os manifestos distribuídos por Rosa - na verdade, atirados do alto do primeiro patamar da caixa d'água - eram os diversos materiais de divulgação produzidos ao longo de todo o projeto de pesquisa realizado pelo grupo: panfletos de divulgação das oficinas, cartazes da peça em suas várias versões, cartazes anunciando seminários. O processo de criação da peça era literalmente derramado e jogado sobre o público.

Ao falar sobre Stravinsky em Filosofia da Nova Música, Adorno fornece-nos uma exata definição de vanguarda e uma pista para a leitura de Miopia. Adorno apresentanos uma crítica da arte de vanguarda como imitação do comportamento neurótico e, por outro lado, uma atitude normativa quanto ao conceito orgânico de trabalho na estética idealista:

\footnotetext{
${ }^{59}$ ALMEIDA, Ligia Marina; DELMANTO, Ivan; FARIA, Fernanda, et al. Miopia. Inédito, 2006, p. 1.
} 
A Histoire $d u$ Soldat acolhe, em suas configurações, modos musicais de comportamento psicopático. A unidade orgânicoestética fica dissociada (...). O aspecto inorgânico impede toda compenetração e identificação. É formado pela própria partitura. Esta suscita a impressão de algo decomposto (...) que rompe as habituais proporções de equilíbrio. ${ }^{60}$

O que Adorno aponta aqui são as normas da estética tradicional, isto é, a noção de unidade orgânica entre o todo e as partes. Acusa "a desorganização" ao mesmo tempo em que reconhece essa falta de organização como princípio de composição. Não gosta desta decomposição porque seus efeitos se tornaram independentes, por causa de sua “dissociação do significado do todo." Neste caso, o procedimento da montagem, característico da vanguarda, é o grande alvo de Adorno já que em tal proceder: "a composição se realiza não por desenvolvimento, mas pelas falhas que permeiam sua estrutura". Em meio a estas falhas, tão presentes em Miopia, Adorno identifica o choque como característica da montagem presente nas vanguardas:

\begin{abstract}
Pode-se supor que a causa social esteja na desproporção irresistivelmente aumentada no industrialismo tardio, entre o corpo do homem e os objetos, por um lado, e as forças da civilização técnica, por outro; forças que o homem domina sem que seu sensório, ou seja, a possibilidade da experiência, possa dominar o excesso desenfreado, enquanto a forma de organização individualista impede à sociedade comportamentos coletivos que talvez estejam subjetivamente maduros para o estado das forças de producão objetivas e técnicas. Pelos shocks, o indivíduo percebe diretamente sua nulidade frente à gigantesca máquina de todo sistema. $^{61}$
\end{abstract}

Esta renúncia do sujeito artístico a impor-se e opor resistência, contentando-se em expressar os choques ao refleti-los, faz com que o criador "comporte-se literalmente como um ferido grave, vítima de um acidente de que não pode recuperar-se e que por isso repete continuamente o esforço desesperado dos sonhos". A experiência de choque constante, proposta por Miopia, talvez nos sugira que esta nulidade do indivíduo seja carcaterística da subjetividade sob os escombros do capitalismo tardio, em que todas as relações sociais são mediadas pela forma mercadoria. No entanto, a reprodução desta nulidade pelo artista não transformaria a obra em réplica da vivência cotidiana do choque? E mais: o choque já não estaria, neste estágio em que o capital valoriza-se através do comércio de imagens e de experiências, incorporado ao mercado?

\footnotetext{
${ }^{60}$ ADORNO, Theodor. Filosofia da Nova Música. São Paulo: Perspectiva, 2009, p. 135.

${ }^{61}$ Idem, p. 123.
} 
Vista sob este aspecto, retornamos a pergunta já formulada anteriormente. Em uma obra que pretende apresentar um conceito de encenação capaz de organizar a composição de suas distintas dramaturgias, harmonizando conteúdo e forma, um retorno à noção modernista de obra acabada e de contemplação refletida (aspectos tão claramente presentes na estética de Brecht, por exemplo), noção esta que envolve uma crítica das vanguardas tal qual a empreendida por Adorno, não seria mais capaz de gerar aquela experiência artística mobilizadora e desestabilizante que o coletivo de autores de Miopia se propôs?

Veremos a seguir, se não estivermos errados, que o procedimento do choque e a ideia de obra surgem em Miopia presentes em sua ausência, ou vivos em sua morte, ou para definir mais precisamente, como cadáveres. Tais aspectos, bem como outras características do teatro épico e da arte moderna, surgem na encenação de Miopia em processo de decomposição. Não são negados e nem estão presentes. Tal estado arruinado pode ser observado se pensarmos no conceito de obra: Miopia não pode ser considerada uma obra porque configurou-se como um ensaio em devir e não como um produto acabado. No entanto, os ensaios constantes e exaustivos da peça procuravam fixar precisamente seus componentes cênicos, mesmo que fixados para serem modificados. Assim, não podemos dizer que Miopia constituiu-se como um processo aleatório de improvisado e criação. A ideia de obra está presente na peça, mas em sua negação, ou em sua morte constante e repetida a cada apresentação. Esta presença formal constante do cadáver não foi intencionada pelos criadores e talvez possamos dizer que a maior ruína presente na peça seja exatamente a da irrealização e a do fracasso de seus objetivos conscientes e iniciais.

\section{I.3. Tentativas de resposta: constelação em interpassividade}

A imagem que norteou a construção do texto e a sua encenação, durante todo o processo de criação do espetáculo, foi a da constelação. Tal imagem seria cara a Brecht que, se não a utilizou explicitamente, referia-se ao seu teatro épico, como já vimos anteriormente, como teatro planetário.

Inicialmente, ainda presos ao paradigma do teatro épico, mesmo querendo suspendê-lo, as improvisações que dariam origem à Miopia procuravam, por parte de todos os criadores, situações narrativas capazes de orientar, de revelar primeiro ao 
grupo e depois ao público a constelação histórica que estava sendo estudada.

As cenas eram discutidas diariamente a partir do objetivo de criar relações claras entre as diversas situações. Como nas épocas mais remotas, em que os pontos mais brilhantes desses grupos de estrelas, que se destacavam ao olhar do observador, estimularam a imaginação do observador a traçar linhas que os interligassem formando figuras e narrativas significativas segundo as épocas e os lugares. Acreditava-se durante boa parte do processo de criação que a peça deveria ser suficientemente aberta para poder gerar, a partir de pontos luminosos comuns e estáticos - as próprias cenas infinitos traçados de sentidos a serem realizados pelo público.

A metáfora da constelação certamente foi uma das inspirações mais importantes para o filósofo Walter Benjamin. É nas "Questões introdutórias de crítica do conhecimento" de sua tese de Livre-Docência, publicada, no Brasil, sob o título de Origem do drama barroco alemão, que o filósofo alemão, alivia o trabalho de compreensão do leitor recorrendo a imagens de estrelas: "As ideias se relacionam com as coisas como as constelações com as estrelas".

Cabe esclarecer que, na língua alemã, há um certo abuso do termo Konstellation no sentido de não haver consciência do sentido original da palavra ('conjunto de estrelas'). Assim, Benjamin retraduz o latinismo Konstellation para o alemão Sternbild, 'imagem de estrelas', expressão esta que se caracteriza por um maior grau de transparência. Não se trataria apenas de um conjunto (con-stelação), mas de uma imagem, o que significa, em primeiro lugar, que a relação entre seus componentes, as estrelas, não seja apenas motivada pela proximidade entre elas, mas também pela possibilidade de significado que lhes pode ser atribuída. As diferentes narrativas traçadas sobre os agrupamentos de estrelas através dos tempos seriam, assim, resultado de longas observações, ou então considerações, termo este que tem como origem provável sidera, significando, portanto, leitura de estrelas. ${ }^{62}$

A estrutura constelar dos escritos benjaminianos era, naquele momento do processo de criação de Miopia, encarada como um modelo inspirador, a leitura de estrelas como modelo de leitura do espetáculo a ser proposta, que não teria sido suficientemente radicalizado por seu amigo e parceiro artista, Bertolt Brecht:

Embora Benjamin mantenha a linearidade gráfica do texto, ele exige do leitor um máximo de atenção para que não lhe escapem as interligações 'verticais' entre os mesmos. Ao contrário de Brecht, em lugar de uma cômoda sequência de início-meio-fim, o leitor encontra um "mosaico" de reflexões cuja ligação não é feita através

${ }^{62}$ BUCK-MORSS, Susan. Benjamin. In: BENJAMIN, Walter. The Work of Art in the Age of Mechanical Reproduction, Illuminations, trad. de Harry Zohn. New York: Schocken Books, 1969, p.218. 
da concatenação textual-linear, mas através de uma rede de conexões intra ou intertextuais. Como nas juntas do mosaico, há uma lacuna entre os componentes do texto, o que resulta na necessidade de uma certa distância para sua "contemplação". ${ }^{3}$

Esta estrutura de mosaico foi experimentada na apresentação de um primeiro "corrido" do texto, exercício que envolveu os atores em uma infinita improvisação de seis horas preparada nas duas semanas subsequentes à escrita da primeira versão de dramaturgia da peça. Esta primeira versão do texto, escrita antes do grupo ocupar a Usina, contando com cenas criadas apenas durante a primeira etapa do processo de criação, realizada inteiramente em uma casa vazia na zona sul de São Paulo, era aberta com a seguinte citação de Benjamin:

Incansável, o pensamento começa sempre de novo, e volta sempre, minuciosamente, às próprias coisas. Esse fôlego infatigável é a mais autêntica forma de ser da contemplação. Pois ao considerar um mesmo objeto nos vários estratos de sua significação, ela recebe ao mesmo tempo um estímulo para o recomeço perpétuo e uma justificação para a intermitência do seu ritmo. Ela não teme, nessas interrupções, perder sua energia, assim como o mosaico, na fragmentação caprichosa de suas partículas, não perde sua majestade. Tanto o mosaico como a contemplação justapõem elementos isolados e heterogêneos, e nada manifesta com mais força o impacto transcendente, quer da imagem sagrada, quer da vontade. $\mathrm{O}$ valor desses fragmentos de pensamento é tanto maior quanto menor sua relação imediata com a concepção básica que lhes corresponde. ${ }^{64}$

Esses postulados, presentes na abertura do texto, representavam indicações para a sua encenação. Esta primeira montagem realizada como um exercício de improvisação dos atores, para que o grupo todo pudesse testar a estrutura inteira do texto, partia de uma tentativa de se organizar todo o material criado até aquele instante como uma constelação:

8/08/2005: SINOPSE ATÉ AGORA: Contradição entre duas narradoras: a narradora abelha e a narradora aranha: uma constrói com linearidade, outra prende o público na gosma do seu labirinto: Rosa contra Mércia. Através do embate das duas narradoras contase o seguinte: 1. Praça dos desempregados. 2. Chegada no Mato Grosso: chegada no vazio. 3. Circo do Autômato Turco profetiza a construção de uma cidade dos sonhos. 4. Briga pela terra. 5.

${ }^{63}$ DELMANTO, Ivan. Relato do primeiro ensaio aberto. ALMEIDA, Ligia Marina; FARIA, Fernanda; DELMANTO, Ivan, et al. Anjos do desespero. Relatório da segunda etapa de pesquisa. Apresentado à Secretaria de Cultura do Município de São Paulo, 2005, p. 64. Inédito. Disponível para consulta na Divisão de Fomento da Secretaria Municipal de Cultura.

${ }^{64}$ BENJAMIN, Walter. Origem do drama trágico alemão. Lisboa: Assírio \& Alvim, 2004, p. 2. 
Construção da cidade. 6. Chegada de Mércia, arquiteta do cinema de comerciais da cidade. 7. Construção do cinema de comerciais. 8. Greve do olhar. 9. Peste das imagens, surgida com o fechamento do cinema. Peste imaginária. Peste imaginada. 10. Destruição do cinema para construção de um shopping center. ${ }^{65}$

A narrativa básica da peça naquele momento já estava esboçada e pouco mudaria até o final da futura temporada, mais de um ano depois. Nesta sinopse, a ação da peça está marcada não por conflitos entre os personagens, mas por movimentos no espaço da narrativa: Praça dos desempregados, Mato Grosso, Miopia, Cinema, Shopping. Os personagens quase não são mencionados, como se o importante a ser tratado fosse a história de transformação espacial da narração. Veremos adiante que tal dissolução do motor tradicional do drama, o personagem e a ação, será confirmado na versão final da peça exatamente pela utilização do espaço cênico em que o espetáculo foi realizado, que se sobrepunha aos atores e às situações apresentadas pelo texto, fazendo com que em Miopia a fábula e os caracteres dos personagens dessem lugar ao périplo espacial, em um trânsito por diversos depósitos de ruínas.

Entretanto, meses antes, caberia ao público que veria as cenas da sinopse acima, naquele momento formado só pelo próprio grupo (diretor, cenógrafo, figurinista e iluminador) "contemplar" as cenas e ver - à maneira do observador de estrelas - quais os elementos em destaque e quais as ligações que poderiam ser estabelecidas entre estes pontos. O que se concluiu de imediato, logo após a primeira realização dessa versão de dramaturgia, é que a contraposição entre as duas narradoras não seria suficiente para criar a variedade de vozes que uma constelação de cenas exigiria. Neste momento passou-se a improvisar cenas em que todos os oito personagens centrais da trama fossem também, em algum momento, narradores da história.

Se considerarmos que as constelações não são formações naturais, mas sim "imagens culturais", diferentes segundo as épocas, projetadas sobre a disposição das estrelas em relativa proximidade, a leitura do espetáculo constelar estaria caracterizada pela liberdade de estabelecer ligações entre partes dispersas. Ao contrário da lógica da progressão do teatro épico linear que, constantemente, acrescenta elementos novos, o texto constelar se distingue por "explosões" e pelo "recomeço perpétuo".

A repetição das mesmas coisas em contextos diferentes, na verdade, não é

${ }^{65}$ DELMANTO, Ivan. Caderno de direção - 2005. In: ALMEIDA, Ligia Marina; FARIA, Fernanda; DELMANTO, Ivan, et al. Anjos do desespero. Relatório da segunda etapa de pesquisa. Apresentado à Secretaria de Cultura do Município de São Paulo, 2005, p. 70. Inédito. Disponível para consulta na Divisão de Fomento da Secretaria Municipal de Cultura. 
repetição, pois trata-se de considerar os "vários estratos de sua significação"; ao procedimento "horizontal" do texto linear, Benjamin opõe a "verticalização" de determinados tópicos. Nessa primeira improvisação, a referida estrutura de repetição surgia em cenas que eram reproduzidas mais de uma vez, por atores diferentes, e situações que eram representadas sob dois pontos de vista contraditórios. A "verticalização" deu-se de maneira literal, com uma exploração espacial por parte dos atores dos planos alto e baixo da cena, fazendo cenas no alto de morros e no chão do pátio, dentro de uma casa e no seu telhado.

A esta primeira ideia de constelação, a versão última da peça acrescentou aspectos que poderíamos traduzir sob a imagem do relâmpago. Com a destruição da linearidade como primeiro passo rumo a uma estrutura constelar, o público era reiteradamente confrontado com o conceito da explosão e de seus similares, tais como a imobilização, a cristalização, o salto, o relâmpago e o choque:

Numa Galeria abandonada de Miopia. Sobre o cego, que está deitado, um letreiro arrebentado em que se lê "PASSAGEM DO ESQUECIMENTO". Há lojas abandonadas formando a galeria. Diotima tenta atrair clientes.

DIOTIMA - (canta) Diotima. Mina. Ensina. Os frescores da vagina. Diotima... Ilumina. Eu vou apodrecer nesta cidade. Eu era uma cantora, todos me amavam, sabia!? Eu era admirada, entende!? Onde estão todos? Eles me abandonaram! Eles se foram, eu sei. Eu preciso de ajuda. Mas eu não entendo o que o senhor quer que eu faça. Eles me mandaram procurar o Cego Keuner porque disseram que ele é um filósofo, um sábio. Quem é você?

CEGO KEUNER - Eu sou um anônimo. Reúno em mim o plágio e o pastiche de toda a sabedoria humana. Sou uma citação. Eu sou a reunião de todos os filósofos do mundo. Desde que você me pague.

DIOTIMA - Eu ainda não entendi o que o senhor quer.

CEGO KEUNER - A única mercadoria que você tinha a oferecer, em troca da sua subsistência, era a sua voz. Hoje ela não interessa mais a ninguém. O único produto que lhe resta é o seu corpo. Você tem que saber colocá-lo em exposição.

DIOTIMA - Eu vou tatuar um preço na minha vagina.

CEGO KEUNER - Perfeito: enterre o valor na sua buceta! E tatue o preço com uma tinta que possa ser apagada e refeita, de acordo com as oscilações do mercado.

CEGO KEUNER - O que você está fazendo? Narre para mim.

DIOTIMA - Minha boca brilha em luz vermelha. Minha vagina pulsa em luz azul. Estou me movendo como uma série infinita de fotografias eróticas. Meus olhos estão fixos em você. Meus movimentos são uma lenta sucessão de imagens eróticas. Eu retiro a roupa devagar, peça por peça. Sou uma peça publicitária. (O Cego Keuner se masturba).

DIOTIMA - Eu ajudo. Nós combinamos. (Ele goza quando ela toca seus olhos). 
CEGO KEUNER - Estas ruínas são o seu palácio. Os consumidores te esperam. ${ }^{66}$

Há distintas materializações desta imagem do relâmpago na encenação do fragmento citado acima. Terceira cena da peça, o trecho iniciava-se de maneira repentina, sem encadeamento com as ações anteriores e subsequentes, em um momento de Miopia em que o público vagava pelo lado de fora da Usina, circundando-a sem encontrar entrada, deparando-se neste percurso com pequenas explosões, situações envolvendo personagens ainda desconhecidos, não situadas na sucessão da narrativa.

A atriz que atuava como Diotima explorou a emissão do seu texto de forma a confundir canto e recitação:

Trabalho com Diotima. Dificuldade extrema. Precisamos fazê-la cantar mal, de forma esganiçada. Intercalar a este canto o texto, como se recitasse um poema infantil. Misturar os sons todos. ${ }^{67}$

As frases explodiam em destroços, rápidas, intercalando maneiras muito diferentes de se dizer o texto, tornando-o de difícil compreensão. O outro personagem, Cego Keuner, apresenta-se como citação e pastiche do dialético personagem de Brecht, agindo, no entanto, às avessas de um sábio: sua ação central consistia em treinar Diotima, ensiná-la a utilizar o próprio corpo como mercadoria capaz de enfeitiçar possíveis compradores que, neste caso, eram representados pelo público, espectadores impassíveis no treinamento. Ao tomar forma de um treinamento, a cena era apresentada de maneira quebrada, interrompida, constantemente reiniciada e repetida: os exercícios e movimentos sugeridos por Keuner eram realizados várias vezes por Diotima e a cena também era algumas vezes retomada, com ações e falas sendo feitas e refeitas. A cena tomava feição assim de ensaio, com uma sobreposição de ensaio e treinamento, como se o próprio trabalho artístico daqueles atores, e da II Trupe como um todo, autores da peça, pudesse ser comparado a um treinamento de sedução e venda.

Keuner marcava o ritmo de suas instruções com um bastão, batido contra o chão e contra o corpo de Diotima sob inúmeros ritmos diferentes: a cada batida Diotima congelava os movimentos de seu corpo, dando forma às instruções do sábio cego. Este congelar e descongelar da ação era marcado pelo acender e apagar da pequena lâmpada

66 ALMEIDA, Ligia Marina; DELMANTO, Ivan; FARIA, Fernanda, et al. Miopia. Inédito, 2006, p. 3.

67 DELMANTO, Ivan. Diário do processo. In: ALMEIDA, Ligia Marina; FARIA, Fernanda; DELMANTO, Ivan, et al. Anjos do desespero. Relatório da segunda etapa de pesquisa. Apresentado à Secretaria de Cultura do Município de São Paulo, 2005, p. 80. Inédito. Disponível para consulta na Divisão de Fomento da Secretaria Municipal de Cultura. 
que iluminava a cena, dando ao resultado a aparência de relampejar. O acúmulo de referências, de vozes, de movimentos e de versões apresentadas na mesma cena (a cada repetição tendo a mesma ação realizada de maneiras distintas), afasta-se da ideia da constelação e apresenta alguns traços da feição geral da peça, que podemos agrupar sob a imagem do acúmulo de lixo e ruínas. É como se o desenrolar da cena acima, marcado por estes diversos relâmpagos, revelasse ao fim da convulsão restos de referências teatrais e de uma experiência histórica mercantilizada.

Do ato inicial destrutivo, empreendido pela encenação, resultaram as ruínas, os escombros, os fragmentos e até mesmo os farrapos e detritos do material textual inicial, que apresentavam dificuldades para serem constelados e para gerar novos sentidos para a leitura das estrelas. O relâmpago talvez sirva melhor como imagem de uma cena que explode constantemente a si mesma, de uma narrativa que se conta ao dissolver-se, de uma obra que é criada através da montagem de inúmeros detritos: pedaços de textos de autores diversos, cenas há muito improvisadas e depois retomadas, cenário e iluminação sucateados, agrupamento de ruínas.

O texto produzido para aquela longa primeira improvisação da sinopse (realizada fora do espaço cênico definitivo) sofreu poucas transformações estruturais em relação à versão final do texto de Miopia. No entanto, os elementos de encenação mencionados acima, todos provindos do diálogo com a Usina e com o lixo abundante no espaço, modificaram radicalmente o sentido do texto, mesmo que com as palavras originais mantidas quase que em sua integridade. Em um relato da diretora técnica do grupo sobre a construção das cenas podemos entender melhor tal aspecto da construção da peça:

De um dia para o outro a prefeitura despejou toneladas e toneladas de lixo na Usina. Os aterros da cidade inteira estavam fechados e eles não tinham onde por o lixo. Jogaram nos lugares abandonados, entre eles a Usina onde estávamos ensaiando. Os atores e o Ivan resolveram ensaiar mesmo assim. Eram montanhas e montanhas de lixo, cobrindo a Usina toda, na parte de fora. E dentro o cheiro era insuportável. Eles fizeram duas cenas, depois não aguentaram. Mas as cenas entraram na peça. Eles diziam o texto dentro do lixo. Depois o lixo saiu, mas as cenas ficaram. ${ }^{68}$

O procedimento de "dizer o texto dentro do lixo", mencionado por Margarida, foi um exercício conduzido por mim em que os atores deveriam dizer o texto de inúmeras

${ }^{68}$ ARES, Margarida. Depoimento gravado, presente no documentário: Miopia. Roteiro e direção André Moncaio, 2006. 
maneiras, sem preocupar-se com as relações presentes nas cenas ou com o sentido original das frases e palavras, buscando apenas uma relação com o espaço. Tal experimentação, calcada no diálogo com um espaço abarrotado de lixo, trouxe aos atores sentidos inesperados, novas formas físicas de executar as ações e de dizer o texto. Tal "lixo", ao contrário do lixo despejado pelos caminhões, não só permaneceu na estrutura final da peça mas orientou todo o trabalho posterior com o texto.

Tal panorama, no entanto, diverge bastante daquela primeira versão testada, que tinha como epígrafe e objetivo da encenação o texto de Benjamin sobre a constelação citado acima: aquela primeira versão acreditava na contemplação refletida e ativa do público, que seria capaz de organizar as estrelas vistas em uma transparente e orientadora constelação de sentidos.

Mas não estaria esta primeira versão abandonada, não obstante toda a sua precariedade de material ainda sem elaboração, mais próxima daquela estética do mapeamento cognitivo, de que nos falava acima Jameson? Sob o céu das constelações de conceitos e de imagens, esta forma teatral não seria mais eficaz, sendo capaz de contrapor-se à fluidez perpétua da forma mercadoria e a todos os seus encantos que submetem e hipnotizam o público/divíduo/consumidor?

Apoiando-se na teoria psicanalítica, para a qual o desejo humano estaria ligado, desde o início, à proibição, ou seja, "para o sujeito desenvolver o desejo, alguma coisa tem que estar fora de seus limites", Salecl discorre como passamos a viver em um contexto no qual o sujeito vivencia um mundo onde há uma perda dos limites sendo, portanto, provocador de angústia. Baseando-se em relatos clínicos, a autora demonstra como tal processo tem gerado uma angústia paradoxal, levando a uma forte identificação com figuras de autoridade, dentre as quais, a identificação com as marcas publicitárias, através das quais o consumidor pode criar seu próprio estilo, desde que opte por uma filiação a uma marca no supermercado das identidades.

Tal perspectiva parece fazer sentido se lida à luz das tendências de consumo apontadas pela pesquisadora de mercado Melinda Davis, para quem a sociedade atual estaria vivendo em um tempo no qual "ansiamos por um poder sobre-humano para nos mostrar o caminho, explicar-nos tudo, contar-nos o que devemos fazer e o que desejamos realmente". A autora reconhece que isso induz à submissão e que pode indicar um território perturbadoramente totalitário. Mas vaticina que já estávamos vendo "uma nova disposição extraordinária - e amplamente inconsciente - da parte dos consumidores para se tornarem discípulos de poderes superiores. $\mathrm{O}$ argumento lógico da 
autora ao descrever esse "novo desejo fundamental" baseia-se no que ela chama de uma “exaustão psíquica do consumidor", que o levará a abrir mão do excesso de escolhas em nome de um alívio do estresse mental.

Esse percurso em busca de orientação e alívio não é o percurso do público/divíduo/consumidor pelos espaços em ruínas na usina de Miopia? O público é submetido a uma avalanche de imagens, de informações, de palavras, de orientações e desorientações, de ordens e de pedidos que passa a obedecer, passivamente: abre mão de sua capacidade de escolha quando a delega aos personagens que o conduzem por um labirinto em que cada saída, cada cena terminada ao ser incapaz de explicar a anterior, surge imediatamente barrada.

Sob este ponto de vista, a forma instável de Miopia, acompanhada do seu périplo controlado oferecido ao público, não seria capaz de, ao mesmo tempo em que mimetiza a forma mercadoria em sua nova máscara mortuária, transcendê-la, obrigando o público a deparar-se com o negativo desta máscara? Talvez em Miopia o negativo da máscara fetichizada da mercadoria seja o lixo.

Mas como se dá este enfrentamento com o lixo? Ao propor uma forma de experiência coletiva e de interatividade que formam hoje a forma hegemônica da mercadoria, Miopia seria capaz de gerar algum confronto? O público não "estaria em casa" ao assistir um espetáculo que mimetiza um passeio ao shopping, desconfortável é verdade, mas cotidiano?

Para falar da relação que estabelecemos com as mercadorias em tempos de comercialização da experiência, Slavoj Zizek elabora um conceito que talvez nos ajude a pensar o lixo negativo de Miopia:

Como resolver o seguinte equívoco: interagir com a máquina ou deixar que ela aja por mim? Na minha opinião, a solução consiste em mudar de perspectiva para se concentrar numa outra forma, muito mais estranha, de descentramento. O impacto verdadeiramente inquietante dos novos media não reside tanto no fato de as máquinas nos arrancarem a parte ativa do nosso ser mas, precisamente, e de forma oposta, no fato de as máquinas digitais nos privarem da dimensão passiva da nossa vivência: elas são passivas "por nós". ${ }^{69}$

Mais adiante, Zizek esclarece que não está falando apenas das máquinas:

Isto nos traz de volta ao estranho fenômeno da interpassividade: não será o reverso necessário da minha interação com o objeto essa situação em que o próprio objeto se apropria da minha reação

${ }^{69}$ ZIZEK, Slavoj. A subjetividade por vir. Lisboa: Relógio d’água, 2006, p. 15. 
passiva de satisfação (ou de tédio ou de gozo), privando-me dela, de modo a ser ele próprio a gozar o espetáculo no meu lugar, aliviando assim o meu superego do dever de me divertir? Não testemunhamos hoje o fenômeno da interpassividade em muitas publicidades televisivas que, tal como se apresentam, parecem desfrutar o produto em nosso lugar? (...) O objeto que dá corpo a um "mais-gozo" fascina o sujeito, reduzindo-o (a) a um olhar pasmado e impotente, que aspira ao objeto. $\mathrm{O}$ sujeito, evidentemente, experimenta esta relação como algo de vergonhoso, de indigno. Ser diretamente paralisado pelo objeto, estar passivamente submetido ao seu poder de fascínio é, no fim das contas, insuportável. A manifestação aberta desta atitude passiva do "goza-o" priva, de certo modo, o sujeito de sua dignidade. Assim, a interpassividade deve ser concebida como uma forma primordial do sujeito contra o gozo, através dela, transfiro o meu gozo para o Outro, que o suporta passivamente (rindo, sofrendo, chorando) no meu lugar. ${ }^{70}$

Talvez a experiência artística a que Miopia submeteu o público possa diferenciarse do seu contrário e semelhante, a forma mercadoria, se a enxergarmos não como proposta de interatividade, mas como proposta de interpassividade. E não a interpassividade de que nos fala Zizek, baseada nas relações fetichizadas da mercadoria, mas uma relação de interpassividade com o lixo.

O lixo está presente em todo o espetáculo. Além da peça se passar no espaço abandonado de uma Usina de Compostagem de Lixo, e de o público percorrer neste lugar o percurso do lixo ao ser triturado, a presença do lixo afoga o espectador durante todo o tempo: o cenário é construído apenas com dejetos; com a recriação de produtos jogados fora; recolhidos pela cooperativa de reciclagem de lixo que trabalhava na Usina; retirados do lixo trazidos pelos membros do grupo ou criado com os objetos descartados, inúmeros, que ao longo de anos de abandono cobriram toda a Usina.

Esta presença do lixo abandonado tornou-se parte do espetáculo que não procurava escondê-lo mas, pelo contrário, colocar os personagens em diálogo direto com estes dejetos, fazendo com que o público também se movesse em meio a eles. A iluminação utilizou-se de material arruinado, carcaças de antigos refletores há muito fora de uso e de fontes de luz alternativas: engenhocas produzidas de maneira precária, que não pretenderam nunca esconder seu caráter de sucata. A própria construção dramatúrgica dos personagens, seja no texto, seja na atuação dos atores, procurou apresentar os seres humanos da narrativa como dejetos.

Este defrontar-se com o lixo o tempo todo, em um contato próximo, de tão

${ }^{70}$ Idem, ibd. p. 33-34. 
nauseante, tornava-se, à medida que o espetáculo progredia, natural. O público delegava aos personagens a função de conduzi-lo e de decidir por si. Por mais que se movimentasse, a relação do espectador não era a de intervir e de participar da obra, mas era a de delegar, passivo, o seu movimento, as suas sensações e escolhas ao que lhe aparecesse pela frente. E o que lhe surgia sempre pela frente era o lixo, em suas inúmeras manifestações.

Em $O$ preço do progresso, um dos fragmentos que conclui $A$ Dialética do Esclarecimento, Adorno e Horkheimer citam a argumentação de Pierre Flourens, um fisiologista francês do século XIX que toma posição contra a anestesia médica com clorofórmio, defendendo que é possível provar que o anestesiante só funciona na rede neuronal da memória. Em suma, enquanto se é cortado vivo no meio da mesa operatória sente-se plenamente o sofrimento em todo o seu horror, mas ao despertar já não há recordação alguma. Para Adorno e Horkheimer, tratar-se-ia da metáfora perfeita do destino da Razão baseado na repressão da própria natureza: o corpo, a parte da natureza no sujeito, sente plenamente a dor; porém, devido a esse recalcamento, não se lembra de nada. É aqui que residiria a vingança perfeita da natureza subjugada: inconscientemente, é possível sob este prisma ser a maior vítima de si próprio, esfolar-se vivo.

É possível perguntar-nos, portanto, se não está na relação de interpassividade, de delegar o seu gozo e a sua náusea para o lixo, uma experiência negativa que Miopia possa ter causado ao seu público controlado. O texto trata, a todo instante, o público como trabalhadores:

11. MARCO INICIAL DA CIDADE

Trabalhadores do Circo e público juntos, com estacas e cordas na mão. Enfileirados atrás de uma faixa: PARTIDA PARA O SONHO.

BELMIRO - (Ao lado do Autômato Turco. Para o público) Companheiros: vamos de vitória a vitória e de triunfo em triunfo! Antes de iniciarmos as celebrações, eu gostaria de propor um viva aos operários do mundo! Hoje, no ano de 1932, comemoramos o aniversário de quinze anos da Revolução Soviética! Viva! (Silêncio total) Viva! Não sejam tímidos, camaradas! Os comunistas só querem paz, pão e terra! (Se não houver silêncio pedir silêncio ao público)

VOZ TÍMIDA - Terra!

FAUSTO - Nós não somos mais comunistas! Nós não somos mais fascistas! Nós não somos mais liberais! Nossa pátria é o desterro, o exílio, o deserto! (Aplausos entusiasmados) Não queremos saber dos políticos tradicionais! (Aplausos entusiasmados) Só queremos ter onde morar e onde criar nossos filhos! (Aplausos entusiasmados) Por isso aqui estamos para fundar uma nova 
cidade! (Aplausos entusiasmados. $\underline{\text { Pedir aplausos do público) }})^{71}$

Assim como na cena acima, os personagens dirigem-se o tempo todo ao público tentando trazê-lo para o espaço ficcional de Miopia, cidade em que todos seriam cohabitantes. Mas esta experiência inicial que propunha a peça naufragou. Em nenhum momento, seja pela forma como a encenação expressou esse texto, seja pelas próprias estruturas de sentimento que contaminam o público e que se encontram mimetizadas na peça, o público interage com a obra, em nenhum instante tornava-se co-criador, sendo capaz de transformá-la.

No entanto, ao aceitar o percurso e as ações que lhe eram propostos, o público tornava-se responsável por seu próprio dilaceramento, como no fragmento da Dialética do Esclarecimento citado acima. As diversas versões da peça foram realizadas, mas não por uma relação de interatividade com o público, pelo contrário, através de uma relação interpassiva, em que os artistas da II Trupe de Choque mudaram sucessivamente as cenas através da observação dessa passividade que tomava o público. Ninguém nos fez nenhuma sugestão de mudanças para as cenas. As pessoas saíam da peça em um estado de paralisia que as impedia até de preencher o questionário que no começo da temporada oferecíamos ao público, para saber de suas opiniões, endereço de email etc.

Talvez esta paralisia resida nesta experiência mimética da forma mercadoria e dos seus movimentos e feitiços, mas realizada como reprodução de uma forma esvaziada de seu produto, preenchendo este vazio com o lixo, negativo exato da máscara mortuária que o espetáculo pretendeu criticar. Se este diálogo interpassivo com o lixo é capaz de promover uma reflexão crítica para além do vazio ou da paralisia é-me impossível responder.

\section{I.4. Diário do lixo: processo de ensaio}

Há um procedimento de ensaio que talvez represente adequadamente o surgimento do espetáculo e da primeira alegoria do lixo com que nos defrontamos: os desempregados despejados como lixo no interior do Mato Grosso, notícia histórica que deu origem à peça. Tal procedimento pode ser interessante também por sua permanência, já que foi repetido, com infinitas variações, durante todo o processo de

\footnotetext{
${ }^{71}$ ALMEIDA, Ligia Marina; DELMANTO, Ivan; FARIA, Fernanda, et al. Miopia. Inédito, 2006, p. 8.
} 
criação, solidificando-se depois no trabalho corporal e em muitas das ações executadas pelos atores na encenação do espetáculo. Alguns fragmentos de Hegel foram selecionados e lidos pelo grupo.

Ao final dessa leitura coletiva, que se deu ao longo de três ensaios, em que cada termo e conceito presente nos fragmentos do filósofo alemão foram lidos e relidos, tematizados e discutidos em conjunto, eu elegi o seguinte trecho para ser objeto de uma prática corporal:

A diferença é em si a diferença essencial, o positivo e o negativo, assim que o positivo de tal modo é a relação idêntica para consigo, que não é o negativo; e este de tal modo é o diferente para si, que não é o positivo. Sendo cada um para si, enquanto não é o Outro, aparece cada um no Outro, e só na medida que o Outro é. A diferença da essência é por isso a oposição, segundo a qual o diferente não tem frente a si o Outro em geral, mas o seu Outro, isto é, cada um tem sua própria determinação só na sua relação ao Outro; só é refletido sobre si enquanto é refletido no Outro, e o Outro, do mesmo modo: cada um é assim seu Outro do Outro. (...) na doutrina dos conceitos contraditórios, um dos conceitos significa, por exemplo, azul, o outro significa não-azul, de modo que este Outro não é algo afirmativo, como seria, digamos, amarelo; mas somente deve afirmar-se como sendo o negativo. (...) O positivo é o idêntico consigo mesmo, mas enquanto determinado frente a um Outro; e o negativo é a diferença, como tal, na determinação de não ser identidade. É isso a diferença da diferença nela mesma. No positivo e negativo acredita-se ter uma diferença absoluta. Contudo, os dois são em si mesmo, e por isso se poderia chamar também o positivo, negativo, e vice-versa igualmente: o negativo, positivo. O mesmo se dá com um caminho para o leste que é ao mesmo tempo um caminho para o oeste. Positivo e negativo são portanto essencialmente condicionados um pelo outro, e só existem em relação recíproca. $\mathrm{Na}$ oposição, o diferente em geral não tem frente a si somente um Outro, mas o seu Outro. Tudo é oposto. Não há de fato em lugar algum nem no céu nem na terra, nem no mundo espiritual, nem natural, um tão abstrato ou-ou tal como o entendimento afirma. Tudo, seja o que for, é um concreto; por conseguinte, é em si mesmo algo diferente e oposto. Em geral, o que move o mundo é a contradição; e é ridículo dizer que a contradição não se deixa pensar. $O$ que há de correto nessa afirmação é somente que não é possível dar-se por satisfeito na contradição, e que ela se suspende a si mesma. Mas a contradição suspendida não é a identidade abstrata, pois essa, em si mesma, é apenas um dos lados da contradição. O resultado mais próximo da oposição posta como contradição é o fundamento, que em si contém tanto a identidade quanto a diferença, como suspendidas e rebaixadas a meros momentos ideais. ${ }^{72}$

\footnotetext{
${ }^{72}$ HEGEL, Georg Wilhelm Friedrich. Enciclopédia das ciências filosóficas em compêndio: a ciência da
} lógica. São Paulo: Loyola, 1995, p. 233-238. 
O procedimento iniciou-se com um aquecimento físico inspirado em exercícios propostos por Meyerhold em seus estúdios:

Os movimentos cênicos

Exercícios em movimentos ex improviso; o corpo humano no espaço, o gesto como onda - ressuscitando a vida por meio do movimento do corpo.

Os movimentos em círculo, em quadrado, em retângulo.

Os movimentos em aposento ou em céu aberto.

Os movimentos e o fundo musical. ${ }^{73}$

Os atores receberam como estímulo inicial para os seus movimentos:

Explorem as oposições. Entre partes do corpo. Entre o impulso que surge do seu corpo e uma força contrária localizada no espaço. Entre a música e o que o seu corpo experimenta. Entre movimentos circulares e retilíneos. Entre movimentos na sala e fora da sala. ${ }^{74}$

Os movimentos eram executados sem nenhum objetivo de representar ações cotidianas e, como tal, tomavam significados abstratos, desenhando linhas diversas no espaço, próximos de uma dança sem partitura definida. O fragmento de Hegel foi impresso e distribuído para cada ator, durante o trabalho de aquecimento, e passou a ser lido enquanto os movimentos eram executados, fazendo com que os atores unissem à exploração corporal um trabalho vocal a partir da leitura em voz alta do texto de Hegel.

Em um segundo momento, após mais de duas horas em que a etapa anterior do exercício foi experimentada, a seguinte instrução foi lançada por mim: "Transformem as oposições em contradições ${ }^{75}$,".

Sem tempo para reflexão, sem interromper o exercício, portanto, cada ator foi convocado a responder, corporalmente, o que havia compreendido da discussão anterior sobre contradição e da leitura dos fragmentos de Hegel. Ao final dessa nova investigação, cada ator selecionou os movimentos mais marcantes realizados durante o exercício de forma a compor uma partitura física, que passou a ser repetida, dentro da sala e fora da sala de ensaio, ao ar livre.

Fixadas estas partituras, lancei a seguinte proposta de improvisação aos atores:

1935. São Paulo. Desempregados em busca de emprego leem anúncios fixados em um muro na Praça da Sé. Camburões da

\footnotetext{
${ }^{73}$ MEYERHOLD, V. E. Estúdio. In: THAÍs, Maria. Na cena do Dr. Dapertutto. São Paulo: Perspectiva, 2010 , p. 389.

${ }^{74}$ DELMANTO, Ivan. Caderno de direção - 2005. Inédito, 11/2/ 2005, p. 33

${ }^{75}$ Idem, p. 34.
} 
polícia cercam a praça e os desempregados são levados com violência para um território abandonado, nos confins do Mato Grosso. A regra é: improvisar esta situação executando somente ações contidas nas partituras físicas de vocês. Vocês têm trinta minutos para elaborar a improvisação. ${ }^{76}$

A regra do jogo, que obrigava os atores a criar uma cena a partir de uma partitura física já fixada - construída sem relação alguma com o tema de improvisação sugerido posteriormente - tinha como objetivo colocar em atrito as metodologias de Meyerhold (de onde surge o aquecimento), de Stanislavski (primeiro encenador a falar em partitura física, mesmo que localizada ainda no terreno realista), e pílulas do pensamento dialético (o fragmento de Hegel) a um tema claramente épico (que poderia ser tratado perfeitamente a partir de procedimentos de Brecht).

Este procedimento de ensaio é representativo por revelar como o grupo trabalhou, na prática, a partir das referências distintas dos encenadores escolhidos para pesquisa, procurando recriar e colocar em choque tais inspirações. O objetivo era buscar uma forma teatral capaz de tratar de conteúdos que já não eram suportados pela forma do teatro épico tradicional. Tais conteúdos foram sugeridos em um novo momento do mesmo ensaio, após os atores apresentarem sua versão de improvisação:

Gostaria que vocês refizessem a improvisação. Utilizando ainda as partituras, mas organizando as ações em outras sequências. Mas sugiro um final para a situação: ao chegar no Mato Grosso os trabalhadores constroem uma cidade dos sonhos, habitada apenas por imagens e lixo. ${ }^{77}$

Esta cidade dos sonhos, improvisada naquele dia em uma longa cena que durou mais de uma hora, foi o primeiro esboço de Miopia, a cidade utópica que dá nome à peça. O negativo do sonho, naquele momento em que estávamos iniciando a ocupação da Usina de Compostagem, tornou-se o lixo. A contradição a ser explorada detinha-se na contraposição entre imagem, fetiche, e lixo, dejeto. A partir do exercício acima, experimentamos pela primeira vez a justaposição do tempo histórico passado, década de 30 , ao presente, representado pelo mercado hipostasiado pelas imagens e produtor incessante de lixo.

Há um relato escrito por uma das atrizes que contextualiza as questões que nos assombravam no momento do processo de criação em que o exercício descrito acima foi realizado:

\footnotetext{
${ }^{76}$ Idem, p.34.

${ }^{77}$ Idem, p.35.
} 
Não se sabe nada sobre o enredo, em que personagem você vai se aprofundar. O que se tem é uma paixão pelo tema que, ainda assim, é uma paixão em constantes transformações de cores e cheiros. Neste mesmo processo, já acreditamos que o caminho era tratar da tentativa de revolução de 35 por meio da história da Olga e do Prestes, nos apaixonamos por estes personagens, lemos o Fernando Moraes (isso bem no começo), depois fomos ler o Konder que falava da derrota da dialética e o Carone que ressaltava o quanto o movimento de esquerda no Brasil carecia de clareza teórica, clareza da situação real do Brasil e o quanto a história dos vencedores absorvia estas manifestações como movimentos utópicos no sentido mais corrente e equivocado do termo. Vimos um boom de Olga e de Prestes, cartas publicadas, filmes e pouca análise do que foi este movimento que resolvemos estudar. (...) Da história direta resolvemos partir para algo mais simbólico. Exploramos o trabalho com as partituras, imagens saturadas de tensão, que fossem a representação do período. Começamos, porém, a sentir que estava simbólico demais, que não tínhamos claro para nós o principal, as contradições latentes no período que continuavam vivas hoje. ${ }^{78}$

O texto retrata o momento do processo de criação através da avaliação que fizemos da improvisação realizada no dia de ensaio descrito acima: as cenas estavam abstratas demais e não conseguiam dar conta das contradições históricas que estávamos estudando e pretendíamos retratar.

Naquele momento, após termos estudado e praticado sobre alguns conceitos inspirados na filosofia dialética, as cenas nos pareciam ainda frágeis formalmente, incapazes de transformar em dramaturgia o conteúdo que vinha sendo refletido teoricamente. Podemos acompanhar na descrição de alguns exercícios que foram ministrados por uma das atrizes do grupo em uma das oficinas de atuação dialética para jovens, realizada durante todo o ano de 2005 na Usina, alguns destes impasses. Os exercícios foram elaborados a partir do que estávamos pesquisando naquela etapa de trabalho:

I - Tudo o que é sólido desmancha no ar

Objetivo: Trabalho corporal com a partitura física e começar uma discussão sobre o dinheiro e a mercadoria como mediadores universais

1. Pedir a todos que encham uma bexiga. Neste ato de inspirar e expirar pedir para que os alunos percebam todo o ato de respirar, sobretudo o movimento diafragmal.

2. Um balão é jogado ao ar, logo dois e três e quatro. O grupo não deve deixar os balões caírem.

78 FARIA, Fernanda. Relatório de pesquisa. In: ALMEIDA, Ligia Marina; FARIA, Fernanda; DELMANTO, Ivan, et al. Anjos do desespero. Relatório da segunda etapa de pesquisa. Apresentado à Secretaria de Cultura do Município de São Paulo, 2005, p. 121. Inédito. Disponível para consulta na Divisão de Fomento da Secretaria Municipal de Cultura. 
3. É dado um balão para cada aluno. É preciso agora desenvolver movimentos a partir da música e da relação com o balão. $\mathrm{O}$ balão não pode ser abandonado jamais.

4. Escolher quatro movimentos da experimentação com a bexiga e criar uma partitura física utilizando a bexiga.

5. Apresentar a partitura física sem usar a bexiga

6. Discutir em grupos a citação retirada do Manifesto Comunista: "Tudo que é sólido desmancha no ar. Tudo o que é sagrado é profanado e os homens são obrigados finalmente a encarar com serenidade suas condições de existência e suas relações recíprocas".

7. Elaborar uma cena que reflita o que cada grupo refletiu sobre a citação. Na cena os alunos devem usar as partituras construídas no exercício da bexiga.

8. Avaliação coletiva das cenas, de todo o encontro e discussão coletiva sobre a citação. A forma encontrada pelos alunos para as cenas é a mais adequada para refletir o conteúdo da citação? Como foi utilizar as partituras na cena?

II - Totalidade

Objetivo: discutir teoricamente a partir de um experimento plástico/dramatúrgico o conceito da filosofia dialética.

1. Grande conversa sobre o conceito da Totalidade a partir de referências da aula passada (não é apresentada nenhuma conexão entre o cenário de representação burguês, ex. a casa com a situação política, econômica e histórica em que se encontram) e da imprensa burguesa (apresentação de jornais de várias procedências) que apresenta suas notícias como partes que não tem nenhuma conexão entre si e tão pouco com a Totalidade (afinal a pobreza do pobre é uma questão de mérito e não circunstancialmente política).

2. Os alunos, organizados em grupos e utilizando arsenal plástico e a série de jornais, devem tentar refletir em uma cartolina sua reflexão sobre a Totalidade inserindo e conectando no cartaz os fatos que a ideologia burguesa faz questão de separar.

3. Apresentação dos cartazes.

4. Discussão sobre os cartazes apresentados e sobre todo o encontro. Como levar para a cena esta forma de enxergar os fatos inseridos na Totalidade? Como a forma artística refletirá isto? ${ }^{79}$

Os procedimentos acima esforçam-se por fixar as descobertas que a pesquisa do grupo vinha empreendendo. No entanto, é possível perceber o quanto o amadurecimento teórico dos conceitos, por parte de todo o grupo, ainda estava por se realizar, mesmo sabendo que o público alvo das oficinas era formado por jovens iniciantes na linguagem teatral. Mais do que isso, a transformação dos mesmos conceitos em procedimento e

79 ALMEIDA, Lígia Marina. Teatro peripatético. In: ALMEIDA, Ligia Marina; FARIA, Fernanda; DELMANTO, Ivan, et al. Anjos do desespero. Relatório da segunda etapa de pesquisa. Apresentado à Secretaria de Cultura do Município de São Paulo, 2005, p. 54. Inédito. Disponível para consulta na Divisão de Fomento da Secretaria Municipal de Cultura. 
exercício teatral, apesar de engenhosa, mostra-se ainda ligada por demais ao modelo do teatro épico de Brecht, sem problematizar a fundo, naquele momento, as bases deste teatro.

A questão central naquele instante do processo criativo estava depositada nas formas de narrar: se queríamos partir da construção de uma cidade de imagens, realizada por "desfiliados", era possível contar esta história? A primeira resposta foi tentar organizar todas as improvisações surgidas até aquele momento sob o ponto de vista de dois narradores, com visões contraditórias. Esta ideia logo foi radicalizada, como mencionamos acima: todos os personagens seriam ao mesmo tempo narradores, e dessas visões múltiplas, representadas em diversas formas de narrar, surgiria, aos pedaços, a história de Miopia. Esta tensão entre os narradores será exposta adiante. 


\section{Saída interrompida 2: a dissolução da autoria no labirinto}

Tudo depende de se pensar um conceito de fracasso que seja complexo e, em si mesmo, pleno de contradições, que preserve tanto as experiências vividas no processo do fracasso quanto a consciência de que o projeto (...) enquanto projeção de um alvo a ser atingido - guarda ainda o seu sentido ${ }^{80}$

Nas constelações cambiantes da matilha, o indivíduo se manterá sempre em sua periferia. Ele estará dentro e, logo depois, na borda e, logo após, dentro. Quando a matilha se põe em círculo ao redor de seu fogo cada um poderá ter vizinhos à direita e à esquerda, mas as costas estão livres, as costas estão expostas à natureza selvagem. ${ }^{81}$

\section{II.1. Preambulações marxistas}

São muitos os grupos teatrais que hoje trabalham com a forma democrática de criação, seja esta coletiva ou colaborativa. Não pretendemos elaborar aqui, de forma abstrata, uma teoria definidora desses modelos de produção, já que, por ligarem-se a processos criativos, tais delimitações são sempre instáveis e marcadas por inúmeras tensões, ligadas às especificidades de cada processo artístico. Toda a produção teórica consultada durante a elaboração desta dissertação, seja esta produção acadêmica ou não, tem como única convergência conceitual absoluta o fato de que os pesquisadores e artistas que investigam tais modos de criação preferem, à maneira de Luis Alberto de Abreu, “preservar o caráter vasto e intuitivo da criação, (...) pelo cuidado, nunca

80 BURGUER, Peter. "Em lugar de um prefácio à edição brasileira." In: ANTUNES, José Pedro. Tradução comentada de O surrealismo francês de Peter Burger. Tese (doutorado) - Universidade Estadual de Campinas. Instituto de Estudos da Linguagem. 2001, p. 365.

${ }^{81}$ CANETTI, Elias. Massa e poder. São Paulo: Cia. das Letras, 1999, p. 97. 
desnecessário, de não objetivar excessivamente o fim pretendido. Não era, e nem é, nossa pretensão estabelecer um conjunto de regras para levar a bom termo a criação de um espetáculo teatral" ${ }^{\prime 2}$. Seguindo esta tradição reflexiva, preferimos portanto atermonos ao objeto deste trabalho, que é o processo de criação de Miopia, destacando nesta experiência criativa a convivência contraditória e simultânea entre determinada prática do processo colaborativo, entre um processo centralizado ou autocrático de criação e entre o que chamarei aqui de modo labiríntico de produção teatral. Neste caso, e por uma vez mais, o que nos interessa é identificar, exatamente o contrário do "conjunto de regras para levar a bom termo" um processo de criação: o interesse de nosso objeto de estudo reside precisamente no fracasso das intenções dos participantes da II Trupe de Choque em estabelecer o processo colaborativo de criação que pretendiam. Salvo maior engano, talvez possamos localizar neste fracasso dados de um sentido histórico de maior alcance.

A especificidade do chamado processo colaborativo, que desde os anos 90 vem sendo experimentado por muitos grupos teatrais em diversas partes do mundo, é manter a existência de funções definidas (dramaturgo, diretor, atores, e todos os demais criadores) organizadas, no entanto, sem nenhuma espécie de hierarquia, com responsabilidades demarcadas sem que isto resulte em áreas totalmente estanques durante a criação:

\begin{abstract}
Entendemos por processo colaborativo o procedimento que integra a ação direta entre ator, diretor, dramaturgo e demais artistas. Essa ação propõe um esmaecimento das formas hierárquicas de organização teatral. Na maioria das vezes, conservam-se as funções e distribuições de tarefas (...). No entanto, os parâmetros que delimitam tais campos tornam-se menos rígidos e a concretude de cada função apenas se realiza sob o viés da participação e da contribuição em cadeia. ${ }^{83}$
\end{abstract}

Com texto e cena sendo criados simultaneamente, a partir de improvisações dos atores e da intervenção dos demais criadores (cenógrafo, figurinista, músicos, documentarista), a forma colaborativa de criação não rompe com a divisão social do trabalho dentro do processo artístico, mas procura quebrar com as relações hierárquicas, entre texto e cena, entre diretor e demais criadores, presentes nos modos de produção autocráticos.

\footnotetext{
82 ABREU, Luís Alberto de. "Processo colaborativo: relato e reflexões sobre uma experiência de criação.” In: Cadernos da ELT, Santo André, v.1, n.0, p. 34, mar. 2003.

${ }^{83}$ FISCHER, Stela Regina. Processo colaborativo: experiências de companhias teatrais brasileiras nos anos 90. Dissertação (mestrado) - Universidade Estadual de Campinas, Instituto de Artes. 2003, p. 39.
} 
Segundo o encenador Antônio Araújo, a abordagem tateante e empírica do processo colaborativo de encenação coloca o diretor também em situação de risco. A sua "autoridade", muitas vezes construída sobre um saber prévio em relação aos rumos da criação, é relativizada ou colocada em suspensão. Ao diretor também, como aos atores, é proposto um mergulho no escuro e no desconhecido. Nada garante a obtenção de um resultado. Além disso, a ideia de "alguém que conduz a um determinado lugar" sofre um abalo, pois este "lugar" será construído coletivamente, ao longo dos ensaios.

Em tal processo, portanto, a formalização da encenação, ocorre a posteriori, a partir da experiência da prática criativa, das improvisações dos atores, das discussões entre todos os participantes, do diálogo com o público. A experimentação e o contínuo câmbio, supressões e desvios, baseados na dinâmica de tentativa-e-erro, tornam-se assim os operadores que construirão o conceito de encenação.

O olhar específico do encenador produzirá uma leitura ou recorte do material levantado. Entretanto tal elaboração de um conceito ou projeto de encenação é construída simultaneamente com os outros elementos do espetáculo, sofrendo contaminações e contraposições a todo tempo e modificando-se ao longo do percurso criativo. Ainda segundo Araújo, no processo colaborativo o encenador, portanto, precisa:

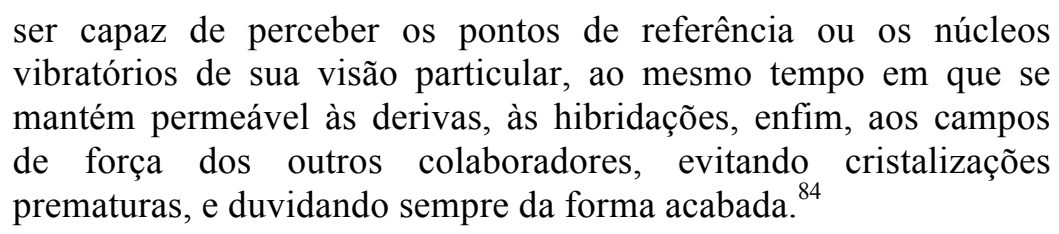

Para Luís Alberto de Abreu, o processo colaborativo provém em linhagem direta da chamada criação coletiva, proposta de construção do espetáculo teatral que ganhou destaque na década de 1970 e que se caracterizava por uma participação ampla de todos os integrantes do grupo na criação do espetáculo: "todos traziam propostas cênicas, escreviam, improvisavam figurinos, discutiam ideias de luz e cenário, enfim, todos pensavam coletivamente a construção do espetáculo dentro de um regime de liberdade irrestrita e mútua interferência" ${ }^{\circ 5}$.

Assim, o processo colaborativo teria surgido, para Abreu, a partir de uma crítica metodológica ao modelo de criação coletiva empregado naqueles tempos:

\footnotetext{
${ }^{84}$ ARAÚJO, Antônio. A Encenação-em-Processo. In: V Congresso da Associação Brasileira de Pesquisa e Pós-Graduação em Artes Cênicas, 2008, Belo Horizonte, p. 1.

85 ABREU, Luís Alberto de. Op. cit., p. 36.
} 
A criação coletiva possuía, no entanto, alguns problemas de método. Um deles era a talvez excessiva informalidade do próprio processo. Não havia prazos, muitas vezes os objetivos eram nebulosos e se a experimentação criativa era vigorosa, não havia uma experiência acumulada que pudesse fixar a própria trajetória do processo. Era ainda uma abordagem da criação totalmente empírica que se resumia, muitas vezes, em experimentação sobre a experimentação. Por outro lado, a ausência de alguém que pudesse organizar ideias, ações e personagens todo material proveniente das improvisações num texto prévio - dramaturgos eram escassos na época - fez com que o diretor comumente concentrasse em suas mãos e em sua ótica, o resultado, a "amarração final", como se costumava dizer. Isso fazia com que o processo perdesse, em determinado momento, seu caráter coletivo, assumindo a visão, ou a proposta de seu diretor. Nesse caso, se anteriormente o grupo dependia totalmente de como o dramaturgo pré-organizava o espetáculo através do texto - o que acontecia no processo tradicional -, agora o coletivo também corria o risco de ter um outro criador que, isoladamente, cumpria essa função, o que fazia com que o ideal de um coletivo criador não se cumprisse integralmente. ${ }^{86}$

Ao contrário do processo coletivo de criação, a encenação processual colaborativa, não busca a fusão ou a união de todas as contribuições artísticas mas sim

estimula e garante a independência das partes, justapõe e fricciona diferentes sentidos ou percepções e coloca as múltiplas e divergentes intensidades, em combate. Poderíamos pensar tal processo de forma assemelhada àquela com que Dort analisa a representação contemporânea não-unificada, na qual “[...] os diversos elementos entrariam em colaboração, e mesmo em rivalidade, ao invés de contribuírem [...] para a edificação de um sentido comum". ${ }^{87}$

A partir dessa visão, o processo teatral colaborativo não é, necessariamente, um campo pacífico e organizado. Ele seria marcado por assimetrias, irrupções, transbordamentos propositivos, conflitos e instabilidades. Tal encenação viveria, então, o paradoxo de querer controlar esse sistema dinâmico e, ao mesmo tempo, de ter pouco controle sobre ele.

No tradicional processo coletivo de criação, por outro lado, a ausência de delimitação das funções impediria a multiplicidade de pontos de vista gerada pela inserção de cada criador sob a prática de específica linguagem artística. Tal ausência de delimitação de funções, se por um lado questiona a divisão social do trabalho no

\footnotetext{
${ }^{86}$ Idem, ibd.

${ }^{87}$ ARAÚJO, Antônio. Op. cit., p.2.
} 
processo artístico, exigindo que todos os integrantes do grupo participem da construção de todas as etapas da obra, teria como resultado uma amortização das diferenças individuais, fazendo com que o processo caracterize-se por uma busca constante, através de discussões e votações, da harmonia e do meio-termo. Haveria sob essa concepção de coletivo a crença de que a antítese do trabalho individual é a voz una do todo, que não comporta a contradição. Por muitas vezes os resultados artísticos desses processos apresentam obras em que as direções de todas as suas dramaturgias são convergentes, dissolvendo as possibilidades de expansão de sentido que a tensão entre as diversas linguagens que formam o fenômeno teatral pode oferecer. Abreu chega a mencionar que esta espécie de processo coletivo

em sua proposta de dar voz e direitos a todos os criadores, muitas vezes conduzia o resultado artístico a uma somatória das criações dos indivíduos, muitas vezes sem síntese e clareza. A ferocidade da crítica da época convencionou comparar alguns desses espetáculos a festas escolares de final de ano ${ }^{88}$.

No entanto, não podemos, salvo engano, encarar o processo colaborativo como uma evolução dentro de uma sucessão linear de modos de produção teatrais, responsável, sob tal enquadramento, por "superar" o modelo coletivo de criação. O ideário político e estético relacionado à experiência histórica destes coletivos era aquele também comum às vanguardas artísticas em que, segundo Walter Benjamin, no seu ensaio "O autor como produtor", de 1934:

Existe uma diferença essencial entre abastecer um aparelho produtivo e modificá-lo. (...) Abastecer um aparelho produtivo sem ao mesmo tempo modificá-lo, na medida do possível, seria um procedimento altamente questionável mesmo que os materiais fornecidos tivessem uma aparência revolucionária. Sabemos, e isso foi abundantemente demonstrado nos últimos dez anos, na Alemanha, que o aparelho burguês de produção e publicação pode assimilar uma surpreendente quantidade de temas revolucionários, e até mesmo propagá-los, sem colocar seriamente em risco sua própria existência e a existência das classes que o controlam. ${ }^{89}$

Assim, para Benjamin, ao artista consciente das condições de produção de seu tempo caberia o trabalho não apenas da fabricação exclusiva de produtos, mas sempre, ao mesmo tempo, a dos meios e dos modos de produção: "um escritor que não ensina outros escritores não ensina a ninguém". ${ }^{90}$ Para os grupos teatrais envolvidos na

\footnotetext{
${ }^{88}$ ABREU, Luís Alberto de. Op. cit., p. 36.

${ }^{89}$ BENJAMIN, Walter. "O autor como produtor". In: Obras escolhidas: magia e técnica, arte e política". São Paulo: Brasiliense, 1994, p. 128.

${ }^{90}$ Idem, p. 132.
} 
investigação dolorosa dos processos coletivos, além de um produto capaz de questionar os modos de subsistência hegemônicos era essencial também organizar a produção criativa sem reproduzir as estruturas de "dominação sociometabólica" (a expressão é de István Mészáros) do capital, a saber, um aparato (re)produtor de alienação. "Ensinar outros artistas" significaria, neste contexto, apresentar também, além de uma obra distante dos padrões teatrais mercadológicos, novos modos e meios de produção, outras formas de organização coletiva que seriam capazes de gerar distintas possibilidades formais. A chave crítica depositava-se no rompimento com a divisão social do trabalho e com suas estruturas alienantes de trabalho.

Neste sentido, no processo colaborativo:

o jogo de forças é muito maior, pois não se trata de
individualidades, mas de funções. O diretor, embora
hierarquicamente equiparado aos demais, fala como diretor,
responde pela encenação, sendo assim, tem em vista o espetáculo e
zela pela melhor solução, independente de quem criou esta ou
aquela cena. O mesmo se dá com o dramaturgo. Embora tenha
interferido nas demais criações, sua responsabilidade específica é
com o texto e, para constrú-lo da melhor maneira, selecionará este
ou aquele material, independente de seu criador ${ }^{91}$.

Seria possível dizer que, ao contrário do modo de produção teatral coletiva, o processo colaborativo surge como uma negociação com o princípio da especialização e da divisão social do trabalho. É importante observarmos que, segundo Adélia Nicolete no fragmento acima, as responsabilidades nesse processo colaborativo estão claramente demarcadas: "o diretor responde pela encenação", "a responsabilidade específica do dramaturgo é com o texto". Neste aspecto, Luís Alberto de Abreu complementa a análise de Adélia:

\begin{abstract}
E aqui começamos a pisar em terreno minado porque esse processo de criação busca também preservar o terreno da criação individual. Como conciliar, então, o aparente paradoxo de fomentar o impulso criativo dos indivíduos dentro do grupo e ao mesmo tempo preservar a permeabilidade das ideias? Como promover o livre trânsito da criação entre os participantes sem eliminar a demarcação dos territórios de criação? Até que limite o ator pode interferir na dramaturgia, o dramaturgo pode interferir no conceito da encenação e assim por diante? Não é possível demarcar os limites dessa interferência. Mais: acreditamos que essas fronteiras não podem nem devem ser delimitadas.(...) ${ }^{92}$
\end{abstract}

\footnotetext{
91 NICOLETE, A. M. Da cena ao texto: dramaturgia em processo colaborativo. São Paulo, 2005. Dissertação (Mestrado) - Universidade de São Paulo, Escola de Comunicações e Artes, p.50.

${ }^{92}$ ABREU, Luís Alberto de. Op. cit, p. 39.
} 
E mais à frente, ainda no mesmo texto:

Para superar e transitar com mais desenvoltura nesse momento fundamental do processo é necessário que se preserve as funções de cada artista. De um lado existe total liberdade de criação e interferência, mas de outro é vedado a um criador assumir as funções do outro. Ou seja, um ator pode discutir, sugerir mudanças, propor diálogos ou até mesmo escrever uma cena, no entanto é o dramaturgo que deverá fazer a organização desse material. Da mesma forma é vedado ao dramaturgo assumir funções da direção ou da interpretação embora se preserve a liberdade de mútuas interferências. Nesse sentido, a responsabilidade de cada um alcança não só sua área específica de criação, mas também colabora na área do parceiro ${ }^{93}$.

A liberdade das mútuas interferências convive, no processo colaborativo da maneira como estamos descrevendo até aqui, com a definição de que é "vedado a um criador assumir as funções do outro". Tal definição metodológica presente neste processo é capaz de nos distanciar claramente das premissas do modo coletivo de criação.

Nas palavras do criador do Teatro Experimental de Cali(TEC), Enrique Buenaventura, que denomina o trabalho do seu grupo de coletivo, apesar de apresentar características semelhantes ao que os pesquisadores que consultamos chamam de processo colaborativo:

O trabalho coletivo não só não elimina a divisão do trabalho, mas também cria uma divisão do mesmo que impede a oposição entre "criadores" e "executores", entre "criadores" e "intérpretes", mais ou menos passivos. Dentro dessa criação coletiva do texto repartem-se as tarefas de tal modo que o "dramaturgo" tem a sua, assim como dentro da montagem coletiva, o diretor conserva não só a sua tarefa específica, como esta se torna mais rica e profunda ${ }^{94}$.

Assim, se não estivermos equivocados, nos processos de caráter colaborativo acredita-se na manutenção da divisão social do trabalho como estratégia, aparentemente paradoxal, de superação da alienação presente na especialização social das funções: é o que Enrique Buenaventura chamou acima de "tornar mais rica e profunda" cada uma das tarefas.

\footnotetext{
${ }^{93}$ Idem, ibd.

${ }^{94}$ Depoimento in: CANCLINI, Nestor Garcia. A socialização da arte: utopia e prática na América Latina. São Paulo: Cultrix, 1984, p. 162
} 
Antônio Araújo destaca, em sua descrição do processo colaborativo, o confronto, a tensão e a contaminação entre as diversas dramaturgias e entre os distintos autores durante a criação da obra teatral.

Diferente de um tipo de teatro mais convencional, em que os limites desses papéis são rígidos, e as interferências criativas de um colaborador com outro, em geral são vistas como um sinal de desrespeito ou invasão, no processo colaborativo tais demarcações territoriais passam a ser mais tênues, frágeis, imprecisas, com um artista "invadindo" a área do outro artista, modificando-a, confrontando-a, sugerindo soluções e interpolações. Nesse sentido, uma "promiscuidade" criativa não só é bem bem-vinda a essa prática, como é, o tempo inteiro, estimulada ${ }^{95}$.

Estaríamos assim diante de um modo de criação que busca, à maneira da sugestão de Walter Benjamin, modificar o aparato burguês de produção a partir de uma outra espécie de divisão do trabalho?

Para a pesquisadora Rosyane Trotta:

Nos processos criativos em que os elementos cênicos, incluindo o texto, permanecem provisórios, o jogo de construção e desconstrução se opera simultaneamente em todas as áreas, não havendo um elemento anteriormente acabado nem criações à margem do percurso coletivo. A função-autor pode parecer fragmentada ou diluída se tomarmos como parâmetro a literatura dramática, comparando um modelo supostamente pleno (a obra fundada por um discurso individual e por isso estilisticamente fechado) a um modelo em que a unidade se perde. No entanto, do ponto de vista da obra-espetáculo, não há diluição e sim pluralidade. (...) Aqui o foco não está na obra, mas no processo. A autoria deixa de ser um atributo do sujeito, tornando-se uma ação que mobiliza aqueles que a promovem e se consuma no ato recíproco de fazer, que necessita tanto encontrar o consenso dentro do dissenso quanto permitir o dissenso dentro do consenso. Vem daí o seu sentido político - e, podemos dizer, mais profundamente político do que aquele impresso em formulações verbais ou fabulares da obra acabada. ${ }^{96}$

Trotta estabelece como categoria central de sua análise o que chama de funçãoautor que, nos processos colaborativos, estaria diluída graças a um movimento de múltiplas vozes, oscilando entre a consonância e a dissonância. O processo colaborativo procuraria, ao manter sua divisão tensa de tarefas, "uma modalidade que procura

\footnotetext{
${ }^{95}$ ARAÚJO (SILVA), Antonio Carlos de. A gênese da vertigem: o processo de criação de O Paraíso Perdido. 2003. 192f. Dissertação (Mestrado em Artes) - Universidade de São Paulo. Escola de Comunicações e Artes, p.105.
}

96 TROTTA, Rosyane. “ Autoralidade, grupo e encenação”. In: Revista Sala Preta, n. 6. Revista do Departamento de Artes Cênicas - ECA - USP. São Paulo, 2006, p. 157. 
conjugar ao mesmo tempo individualismo e pluralidade, e sua principal utopia estaria expressa no papel preponderante conferido ao diálogo entre os sujeitos, na tentativa de exercitar o consenso na ausência de condições propícias para gerar uma identidade coletiva". No entanto, para a mesma autora, caberia perguntar se esta função-autor compartilhada tem tido condições de se formar na prática daqueles que nomeiam colaborativo o processo que empreendem:

Um grupo instaura e sofre a contradição entre os valores que cultiva entre si - e que pretende afirmar artisticamente - e os valores socialmente aceitos - em relação aos quais ele pretende se contrapor. Evidentemente os valores sociais estão dentro do grupo, ainda que como via negativa de onde ele tira a motivação que o empurra para fora, para fincar sua bandeira fora de si. A tensão entre o "dentro" e o "fora" do grupo pode ser sua principal ferramenta no desafio de escapar, pela transgressão, de modelos estéticos ${ }^{97}$.

Não estaríamos aqui diante do que Raymond Williams chama de uma estrutura de sentimento? Se retomarmos este conceito (já mencionado por nós no capítulo anterior) veremos que:

Tais mudanças podem ser definidas como mudanças nas estruturas de sentimento. O termo resulta difícil, sem dúvida, "sentimento" tem sido escolhido com a finalidade de acentuar uma distinção em relação a conceitos mais formais como "concepção de mundo" ou "ideologia". Não se trata somente de que devamos ir mais além das crenças sistemáticas e formalmente sustentadas, ainda que por princípio sempre devamos incluí-las. Trata-se de que estamos interessados nos significados e valores tal como são vividos e sentidos ativamente; e as relações existentes entre eles e as crenças sistemáticas ou formais, na prática, são variáveis (inclusive historicamente variáveis) em uma escala que vai desde a interação mais matizada existente entre as crenças selecionadas e interpretadas e as experiências efetuadas e justificadas. Uma definição alternativa seria a de estruturas da experiência, (...) uma experiência social que todavia se acha em processo $^{98}$.

Para o crítico inglês, essas estruturas são muitas vezes melhor reconhecíveis em um estágio posterior, quando têm sido formalizadas, classificadas e em muitos casos convertidas em instituições e formações. Mas durante os anos 1990, momento histórico em que no Brasil começa a sistematizar-se a experiência dos processos de grupos teatrais colaborativos, o caso é diferente; uma nova estrutura de sentimento teria começado a formar-se naquele tecido social. Esta experiência, que, salvo engano, ainda pode ser chamada de estrutura de sentimento porque ainda encontra-se em processo (por

\footnotetext{
97 Idem, p. 158.

98 WILIAMS, Raymond. Marxismo y literatura. Buenos Aires: Las Quarenta, 2009, p. 180-181.
} 
isso é tão perigoso, como falamos acima, tentar estabelecer parâmetros estanques para a definição destes modos de produção teatral democrática), pode ser localizada, ao mesmo tempo, tanto no impulso, presente nos processos colaborativos, de superar a alienação do aparato hegemônico de produção quanto no seu negativo, as novas facetas, flexíveis e precarizadas, que adquire este mesmo aparato de produção, ao incorporar, cada vez mais, a gestão colaborativa na produção de valor. $\mathrm{O}$ modo de produção colaborativo presente nas empresas é claramente distinto da descrição do processo colaborativo que procuramos traçar até aqui. No entanto, ao manter a divisão de tarefas e a especialização do trabalho, as empresas da era da produção flexível batizam seus trabalhadores de colaboradores, dividindo os lucros e algumas das decisões em caráter participativo sem, no entanto, estabelecer uma relação horizontal nos processos decisórios, objetivo comum em todas as práticas e teorias sobre o modelo teatral colaborativo:

O capital, em escala global, veio redesenhando novas e velhas modalidades de trabalho - o trabalho precário - com o objetivo de recuperar as formas econômicas, políticas e ideológicas da dominação burguesa. Proliferaram, a partir de então, as distintas formas de empresa enxuta", "empreendedorismo", "cooperativismo", "trabalho voluntário" etc., dentre os mais diversos modos alternativos de trabalho precarizado. E os capitais utilizaram-se de expressões que, de certo modo, estiveram presentes nas lutas sociais dos anos 1960, como controle operário e participação social, para dar-lhes outras configurações, muito distintas, de modo a incorporar elementos do discurso proletário, porém, sob clara concepção burguesa. ${ }^{99}$

Essa convivência entre experiência colaborativa, o "dentro" de que nos fala Trotta, e modo capitalista de produção flexível, o "fora" - capaz de incorporar elementos da prática coletiva, sob clara concepção burguesa - parece gerar, em muitos dos processos colaborativos, uma estrutura de sentimento contraditória e dilacerada, em que as tentativas de criação da produção esbarram primeiro em valores e crenças estratificadas. Ainda para falar como Rosyane: "O coletivo não se instaura pela simples reunião de indivíduos dedicados a um mesmo projeto, mas depende da construção de uma 'cultura de grupo' baseada em uma subjetividade coletiva." 100

99 ANTUNES, Ricardo. “Século XXI: nova era da precarização do trabalho?”. In: ANTUNES, Ricardo e BRAGA, Ruy (org). Infoproletários: degradação real do trabalho virtual. São Paulo: Boitempo, 2010, p. 233.

${ }^{100}$ TROTTA, Rosyane. Op. cit.p. 159. 
Esse primeiro obstáculo à experiência teatral colaborativa, baseado em uma estrutura de sentimento que sonha com o colaborativo mas que vive marcada pelos resíduos da noção de indivíduo e de sujeito isolado, soma-se à uma experiência cotidiana do modo de produção hegemônico, que especializa, compartimenta e divide, retirando o controle dos produtores sobre os seus próprios meios e modos de produção. Uma destas segmentações que condensa esta estrutura de sentimento contraditória é a existência de núcleos dentro dos grupos teatrais colaborativos:

Nesta acepção, grupo é definido como "núcleo artístico estável".
Núcleo, que significa ponto central e parte proporcionalmente
minoritária do todo, difere enormemente da ideia de coletivo. A
palavra núcleo dimensiona uma estrutura em que uma minoria
concebe, realiza e mantém a continuidade do projeto, enquanto os
convidados, que representam a maioria, entram no esquema do
trabalho avulso. Não é difícil deduzir que a esta nova configuração
de grupo corresponde uma também nova configuração da autoria.
O centro nervoso do processo de criação cênica se localiza nas
funções de direção, atuação e dramaturgia, embora outras funções
possam participar do percurso. ${ }^{101}$

Durante o processo de criação de Miopia, o núcleo artístico do grupo foi formado por mim, diretor e dramaturgo, e pelas atrizes mais antigas, Elenira Peixoto, Fernanda Faria e Ligia Marina, que foram os idealizadores do projeto de pesquisa. Os demais atores e criadores foram sendo convidados aos poucos, durante o desenvolvimento da pesquisa e, por mais que participassem de todas as decisões relacionadas ao processo de criação, não participavam do núcleo artístico. A contradição, bastante reveladora desta estrutura de sentimento paradoxal, marcada por intenções anti-alienantes em convívio com práticas de gestão hierárquicas (em que o colaborador não detém seus meios de produção e não determina seu modo de produção apesar de ser, de fato, um colaborador), situa-se no fato de que mesmo sem funcionar na prática o núcleo continuava a existir. Mesmo sem marcar reuniões exclusivas, devido a essa difícil construção de uma "subjetividade coletiva", e aos "valores dominantes e sua relação com as práticas e crenças sistemáticas”, a voz destes criadores esteve sempre mais presente e era sempre mais decisiva em cada encruzilhada do processo de ensaio. Como discutir com alguém que fundou o grupo? Como confrontar-se com aqueles que realizaram os testes de admissão para a entrada de novos atores no processo? Por mais que estas questões não fossem expostas ou verbalizadas, eram praticadas enquanto estrutura de sentimento presente no grupo. Assim, a mera existência abstrata do núcleo

${ }^{101}$ Idem, ibd. 
artístico - que marcou uma existência desigual entre os criadores - foi capaz de dificultar, durante a construção de Miopia, aquela essência tensa, aquela instabilidade gerada pelo confronto, definidora do processo colaborativo de que nos fala Luís Alberto de Abreu:

\begin{abstract}
Num processo de criação partilhada não há muito espaço para "minha cena", "meu texto", "minha ideia". Tudo é jogado numa arena comum e examinado, confrontado e debatido até o estabelecimento de um "acordo" entre os criadores. É claro que esse acordo não significa reduzir a criação ao senso comum, nem transformar o vigor da criação artística num acordo de cavalheiros. É um acordo tenso, precário, sujeito, muitas vezes, a constantes reavaliações durante o percurso. Confrontação (de ideias e material criativo) e acordo são pedras angulares no processo colaborativo. ${ }^{102}$
\end{abstract}

Ainda com relação a essa complexa estrutura de sentimento que parece estar presente no momento histórico de emergência do processo colaborativo, vale notar que, a despeito da característica de confronto que parece permear o desenvolvimento de toda a criação colaborativa, Antônio Araújo também nos fala que, ao final de tudo, pode-se chamar esta encenação em processo de uma encenação de alteridades, ou uma encenação negociada. Essa convivência entre negociação e tensão, acordo e confronto é presença constante não só no texto de Araújo mas nas reflexões de Adélia Nicolete, de Luís Alberto de Abreu, de Rosyane Trotta e de Stela Fischer, todas citadas neste capítulo. Assim, talvez seja possível afirmar que o processo colaborativo, marcado por esta convivência entre divisão do trabalho e resistência à alienação, por visões individuais e por acordos coletivos instáveis, sempre em processo, seja este equilíbrio precarizado entre transformação e abastecimento do aparato capitalista de produção. Ou seja, seria possível constatar assim, na prática e na teoria teatral do colaborativo, uma estrutura de sentimento social, definida por um modelo hegemônico em contestação, mas que tem como uma de suas características absorver constantemente experiências que o confrontam. Se o processo colaborativo é capaz de resolver essa contradição a favor da democratização plena das relações de trabalho é uma questão que só pode ser respondida a partir da análise crítica de cada criação em particular. O nosso objeto de estudo revela essa estrutura paradoxal de maneira bastante clara quanto à sua ausência de resolução: o processo colaborativo que os membros da II Trupe de Choque pretenderam experimentar foi convivência simultânea entre modos de produção distintos: foram vividos momentos colaborativos, mas assim como também

${ }^{102}$ ABREU, Luís Alberto de. Op. cit., p. 36. 
preponderaram momentos de processo autocrata de produção (presentes nas questões disciplinares mencionadas no capítulo anterior, por exemplo), com decisões centralizadas no diretor, e do que definirei adiante como "relâmpagos de um modo labiríntico de produção", modelo ornitorríntico de organização do trabalho que pareceu surgir, em muitos momentos, das próprias dificuldades - dilacerantes - que o processo criativo de Miopia propunha aos seus criadores, estabelecendo, inconscientemente, relações horizontais.

Vimos que segundo Antônio Araújo, o processo colaborativo, na verdade, tratarse-ia de uma resultante em constante estado de tensão:

\begin{abstract}
em que as cristalizações e dissipações cênicas são forjadas através de contínuas lutas e negociações. Por ser uma obra "em obras", ela relativiza a todo tempo a sua conformação, interroga-se constantemente sobre a sua materialidade, resultando uma encenação em contínuo confronto com o seu estatuto de precariedade. Ao colocar em diálogo ou confronto os elementos, os materiais e os sujeitos da criação, o processo passa a ser o protagonista da cena. Consequentemente, a direção postula ou encontra o seu discurso não na afirmação isolada de sua individualidade, mas no embate com o outro. A encenação-emprocesso é uma encenação negociada, ou, se quisermos, é uma encenação de alteridades. ${ }^{103}$
\end{abstract}

É possível perceber na citação acima aquela convivência contraditória entre confronto e negociação, tensão e conciliação, que parece definir a complexidade do modo de produção colaborativo. Entretanto prevaleceu no processo colaborativo de Miopia o seu aspecto de negociação, o que aproximou muitos momentos de tal processo, paradoxalmente, de um dos modelos de produção gerencial contemporânea. Se nos voltarmos para o estudo deste modo colaborativo empregado pela II Trupe de Choque durante a criação de Miopia é possível dizer que, apesar de construir-se sobre as bases da tensão, as decisões finais, tomadas de forma colaborativa em tal processo, procuraram negociar e anestesiar as tensões surgidas entre os criadores, em busca de uma amortização das diferenças "em nome do bom produto artístico". Mais do que isto, em caso de extrema dissensão, a última palavra esteve sempre a cargo do diretor, responsável por gerir e definir os rumos do trabalho.

No processo colaborativo de Miopia seus participantes consideravam-se colaboradores, sem problematizar possíveis origens, usos sociais hegemônicos ou desdobramentos de tal nomeação. Assim como nas empresas da era do capital flexível e

\footnotetext{
${ }^{103}$ Idem, ibd.
} 
imagético, quando a produção organiza-se a partir de colaboradores, houve uma separação das funções, que não se dividiram de maneira hierárquica mas que trabalharam segmentadas em busca de uma harmonia em sua produtividade. Tal processo de trabalho é similar às novas técnicas gerenciais corporativas que, para criar a harmonia produtiva no ambiente de trabalho imaterial, procuram transformar cada colaborador em uma empresa com relativa autonomia, limitada pela produtividade do todo:

Fundada em 1986 em Emeryville, na Califórnia, a Pixar desde 1995 vem colecionando sucessos de bilheteria e crítica como Carros, Vida de Inseto e Procurando Nemo. O bom desempenho é consequência do que talvez seja a característica mais visível - e valorizada - da empresa: a criatividade. "Essa é uma qualidade abundante na Pixar porque a empresa estimula a colaboração de todos os funcionários em seus projetos", afirma o consultor americano Bill Capadogli. (...) Algumas empresas, por exemplo, transformaram seus funcionários em sócios. A criação dessa 'mentalidade de acionista' é a melhor forma de se conseguir engajamento, porque o funcionário percebe que ele também ganha se a empresa ganhar. ${ }^{104}$

A metáfora do sócio consegue descrever com precisão o estatuto dos participantes deste processo colaborativo experimentado na maior parte da criação de Miopia. Esta "negociação", que teve sempre, mesmo que após exaustivas discussões e improvisações a palavra final do diretor, pode nos ajudar na reflexão sobre a manutenção de estruturas administrativas e hierárquicas no processo que estamos analisando, por mais que os envolvidos buscassem uma maneira igualitária de organizar suas atividades. $\mathrm{O}$ diretor teatral que, no caso de Miopia, era ao mesmo tempo dramaturgo - concentração de funções que dificultou o equilíbrio de tensões durante o processo, já que havia um único criador com uma espécie de duplo voto -, geralmente era responsável por definir quando a negociação terminaria, e a favor de qual lado do conflito. A "mentalidade acionista" citada na notícia acima, tem como princípio que o sócio é um colaborador do trabalho, participa das tomadas de decisões e da criação e condução da produção sem que, no entanto, consiga realizar aquele estado em que, segundo Marx, o trabalhador liberto da alienação poderia reconhecer que:

Sob o pressuposto da propriedade privada positivamente suprassumida, o homem produz o homem, a si mesmo e ao outro

\footnotetext{
${ }^{104}$ FREITAS, Aiana. Estímulo à colaboração explica sucesso da Pixar. In: O Estado de S. Paulo, Caderno Negócios, 29 de julho de 2010, p. B14.
} 
homem, assim como produz o objeto, que é o acionamento imediato de sua individualidade e ao mesmo tempo a sua própria existência para o outro homem, para a existência deste, e a existência deste para ele. ${ }^{105}$

Tal objetivação do trabalhador, capaz de suspender o estranhamento em relação ao produto de seu trabalho, realizando-se integralmente como sujeito e experimentando a sua "personalidade como objetual" seria possível se os colaboradores/acionistas não estivessem, ao longo do processo colaborativo em Miopia, separados, mesmo que, juntos, assistindo às mesmas cenas em uma mesma sala de ensaio. De novo Marx pode nos ser útil aqui, com sua descrição do trabalho assalariado em Para Crítica da Economia política (Manuscrito de 1861-1863):

Os processos assim separados, realizados como funções desses autômatos vivos, permitem combinação, justamente por meio de sua separação e autonomia, [o grifo é nosso] de modo que esses processos distintos podem ser realizados no mesmo ateliê. A divisão e a combinação se condicionam reciprocamente. $\mathrm{O}$ processo de produção completa de uma mercadoria aparece agora como uma operação composta, um complexo de muitas operações que se completam independentemente umas das outras e podem ser realizadas simultaneamente umas ao lado das outras. (...) Para o trabalhador mesmo, não ocorre nenhuma combinação de atividades. (...) Os trabalhadores constituem os elementos dessa combinação. Porém, a combinação não é uma relação que pertence a eles e está subsumida a eles quando reunidos. ${ }^{106}$

Para Marx, a divisão do trabalho, dialeticamente, estaria formada por separação $e$ combinação. Os colaboradores do processo de criação teatral em Miopia não deixaram de viver esta separação apenas por estarem em um mesmo espaço, criando e apresentando ideias simultaneamente. A chave crítica neste caso talvez esteja em uma colaboração que não pertencia aos criadores: como acionistas, os participantes daquele processo colaborativo estavam subsumidos à produção da obra e deveriam negociar entre si e, principalmente, com o diretor. Tal negociação fez com que a separação e tensão inicial que caracterizava os seus trabalhos individuais fosse combinada em um produto novamente estranho, porque pertencente a processo abstraído do controle do sujeito, funcionando como um sujeito automático que parecia decidir por si próprio.

Ao criarem sob "divisão e combinação condicionadas reciprocamente" os acionistas daquela obra teatral colaborativa não conseguiam mais reconhecer-se no

\footnotetext{
105 MARX, Karl. Manuscritos econômicos-filosóficos. São Paulo: Boitempo, 2004, p. 105.

${ }^{106}$ MARX, Karl. Para a crítica da economia politica. Belo Horizonte: Autêntica Editora, 2010, p. $315-$ 316.
} 
produto do seu trabalho. Este trabalho fora abstraído pelas inúmeras negociações conduzidas pela instância decisória final do diretor, por vezes invisível sob o estatuto do colaborativo, mas responsável por manter a estabilidade das relações de controle naquele processo e por realizar isoladamente a "combinação" final de todas as dramaturgias criadas. Havia controle recíproco: as negociações limitavam cada criador, realizando por fim cenas em que houve desconhecimento e não reconhecimento, reprodução da alienação, exatamente como na empresa mundializada de animação descrita acima.

A discussão empreendida neste capítulo não procura definir o que seriam os diferentes modos de produção teatral coletiva em abstrato, mas sim, a partir de conceitos diversos sobre os processos colaborativo e coletivo, compreender como organizou-se o trabalho de criação em um objeto específico de estudo que, certamente, não se ajusta a nenhuma definição prévia. Assim, importa-nos a tentativa de caracterizar o modo de produção artística de Miopia, que não se desenvolveu de maneira linear, isenta de contradições. Quando os autores da peça conseguiram escapar deste modo de produção fetichizada que escondia, aos próprios artistas, as características do seu trabalho, foram desenvolvidas cenas em que este processo criativo esteve demarcado e exposto, configurando-se como movimento e devir e não como produto acabado. Quando, por outro lado, cada criador não pôde reconhecer-se no resultado de sua atividade, as cenas da peça surgiram como resultado misterioso, em que o vestígio do trabalho de investigação, em suas diversas possibilidades e rastros coletivos e individuais, fora apagado, característica da forma fetiche da mercadoria, sob o império do qual este processo colaborativo em Miopia tentou, geralmente sem sucesso, escapar:

\begin{abstract}
A mercadoria é misteriosa simplesmente por encobrir as características sociais do próprio trabalho dos homens, apresentando-as como características materiais e propriedades sociais inerentes aos produtos do trabalho, por ocultar, portanto, a relação social entre os trabalhos individuais dos produtores e o trabalho total. ${ }^{107}$
\end{abstract}

$\mathrm{O}$ resultado final da peça surge, assim, de maneira desigual. $\mathrm{O}$ aspecto de labirinto e de aparente incoerência entre as diversas opções de encenação davam ao todo de Miopia sua aparência de caos que pode ser compreendida, se não estivermos errados, a partir desta oscilação e instabilidade da experimentação com modos de produção distintos e irreconciliáveis. Se ainda com Marx pensarmos que:

${ }^{107}$ MARX, Karl. O capital. Livro I, vol. 1. São Paulo: Civilização Brasileira, 2000, p. 94. 
A forma pela qual os indivíduos externam sua vida determina o que eles são. Portanto, o que eles são coincide com a sua produção, tanto com o que produzem quanto com o modo como produzem. $\mathrm{O}$ que os indivíduos são depende, assim, das condições materiais de sua produção ${ }^{108}$.

Pode-se acreditar que a uma manifestação artística ligada a novos conteúdos e formas sensíveis estaria relacionado um modo de produção artística determinado, que poderia ser lido pelo trabalho crítico nos intervalos, cesuras e denegações da obra teatral, expandindo seu potencial semântico.

Ao longo de sua existência, a II Trupe de Choque já foi nomeada por seus próprios participantes como um grupo coletivo de criação e, em outros momentos, como um grupo colaborativo. Para além de nomenclaturas abstratas, estas caracterizações revelam, caso escavadas, processos artísticos instáveis, de contínua experimentação e convívio com a crise. Se não estivermos errados, durante Miopia o grupo passou por diversos modos de produção, alternando soluções diferentes e contraditórias para os impasses que o trabalho em conjunto apresentava. Logo no início da pesquisa, os integrantes da II Trupe definiam claramente o seu modo de produção como colaborativo:

Em seu ensaio $O$ autor como produtor, Walter Benjamim, já no final da década de 30, alertava que uma das principais características da sociedade capitalista e do seu aparato burguês de produção artística é assimilar quantidades surpreendentes de temas revolucionários, que são reaproveitados e depois propagados, devidamente domesticados pelas leis rígidas do mercado. Para Benjamin, não basta ao artista consciente e transformador o tradicional arsenal de boas intenções (...) Para romper com a tirania asfixiante do capital, e com sua genética capacidade de regeneração, é preciso romper também com o modo de produção da sociedade burguesa. (...) A especificidade do processo colaborativo é manter a existência de funções definidas. Acreditamos que tal processo é o mais adequado para a obtenção de uma forma teatral preocupada em problematizar a realidade contemporânea em toda a sua complexidade e dinamismo ${ }^{109}$.

Um modelo próprio de experiência colaborativa, além de teorizada e discutida, foi desenvolvida na maior parte do processo de criação de Miopia. Durante essas etapas

\footnotetext{
${ }^{108}$ MARX, Karl e ENGELS, Friedrich. A ideologia Alemã. São Paulo: Boitempo, 2007, p. 73.

${ }^{109}$ ALMEIDA, Ligia Marina; FARIA, Fernanda; DELMANTO, Ivan, et al. Anjos do desespero. Projeto de pesquisa teatral. Contemplado pela V Edição da Lei de Fomento ao Teatro do Município de São Paulo, 2005, p.12. Inédito. Disponível para consulta na Divisão de Fomento da Secretaria Municipal de Cultura.
} 
de trabalho, o meu papel como diretor e dramaturgo era definido como responsável por dar a palavra final na escolha e reformulação de todo o material produzido coletivamente, além de funcionar também como um gerente da produção, administrando conflitos e zelando para que as normas e regras estabelecidas coletivamente fossem rigorosamente cumpridas:

Estávamos muito desgastados, de tanto discutir. A gota d'água aconteceu quando três atores chegaram atrasados em mais de uma hora. Ficamos esperando e discutindo, para definir qual seria a punição para eles, acreditávamos que para o processo andar precisaria haver consequências para os atos de cada um. Definimos que iríamos ensaiar, para não perder mais tempo com falta de compromisso, e que depois o Ivan faria uma conversa individual com cada um, comunicando a decisão tomada por todos que estavam presentes. ${ }^{110}$

Desconhecíamos naquele momento qualquer reflexão mais aprofundada sobre os ditames gerenciais, sistematizados pela ciência administrativa das empresas do capitalismo tardio, da produção colaborativa da era da empresa enxuta, terceirizada e flexível. A referência à reflexão de Walter Benjamin situava-nos, pelo contrário, em um terreno de experiências artísticas que tiveram como horizonte o modo de produção soviético, que opunha-se à produção estranhada sob o capitalismo a partir de uma vertente comunal. No relato de Elenira, encontram-se presentes as decisões tomadas sob a forma de assembleias democráticas, o conselho gestor de trabalhadores e, por fim, a execução das medidas sob a responsabilidade de uma liderança centralizada. Apesar do problema de "indisciplina" ter sido discutido coletivamente, o grupo deixou a cargo do seu diretor a solução final do conflito. Durante a realização das reuniões individuais, eu teria autonomia para aceitar a defesa de cada um dos atores ou para sugerir a sua expulsão do grupo, caso a situação fosse incontornável. O critério para decisões como esta não era, de fato, pessoal, mas tentávamos todos "nos sacrificar" em prol do trabalho. Como tudo girava em torno da intenção de coletivizar este trabalho, a verba que recebíamos da Lei de Fomento ao Teatro era também administrada pelo grupo: destinávamos a maior parte do dinheiro à produção da peça e ganhávamos todos (diretor, iluminador, cenógrafo, figurinista, atores e técnicos) o mesmo cachê de 300

\footnotetext{
${ }^{110}$ PEIXOTO, Elenira. Entrevista gravada em vídeo, concedida a André Moncaio, para o documentário Miopia, 2006. Inédita. Vídeo anexado in: ALMEIDA, Ligia Marina; FARIA, Fernanda; DELMANTO, Ivan, et al. Anjos do desespero. Relatório da terceira etapa de pesquisa. Apresentado à Secretaria de Cultura do Município de São Paulo, 2006. Inédito. Disponível para consulta na Divisão de Fomento da Secretaria Municipal de Cultura.
} 
reais.

Esse convívio, no processo colaborativo de Miopia, entre coletivização e gerenciamento, utopia e hierarquia, modo de produção capitalista e socialista, pode ser identificado também na experiência soviética: “A alternativa hegemônica do trabalho ao domínio pelo capital é inconcebivel sem a erradicação completa do capital do processo metabólico. Por isso, a derrubada do capitalismo pode apenas arranhar a superfície do problema."111

Para Mészáros, a derrubada do sistema capitalista na União Soviética não chegou a instaurar um modo socialista de produção, interrompendo-se durante sua etapa "póscapitalista":

O prosseguimento do domínio do capital no sistema de tipo soviético, sob uma forma politicamente muito diferente, é identificado como principal responsável por tais falhas. (...) Continuaram a explorar e oprimir os trabalhadores debaixo de uma grande divisão hierárquica do trabalho que operava uma extração politicamente reforçada do trabalho excedente à maior taxa possível. ${ }^{112}$

Segundo Mészáros, mesmo todos os esforços de "reestruturação" do sistema stalinista, desde Kruschev até a "perestróika" de Gorbachev, tiveram de naufragar porque os supostos reformadores sempre detiveram o controle da estrutura hierárquica de comando da ordem social pós-revolucionária, com sua extração política autoritária do trabalho excedente.

As contradições do modo colaborativo de produção presente em Miopia refletem esse limite histórico de se concretizar uma alternativa de organização social que supere, mais do que o capitalismo, os princípios do próprio capital. Esse fracasso da coletivização da criação deu-se em Miopia pela dificuldade em superar a relação antagônica/conflitante na qual se executa o processo produtivo sob a dominação estrutural hierárquica do trabalho pelo capital em todas as suas formas conhecidas e possíveis, incluindo-se aí a referência sempre considerada pela II Trupe, a do modelo soviético. Assim como esse modelo, o grupo teatral teve dificuldades de remover as instituições e funções de controle (incluindo, em última análise o Estado como estrutura de comando totalizante do capital), sem as quais esse modo de controle sociometabólico não poderia sobreviver. A coincidência entre os paradigmas capitalista e anticapitalista no processo colaborativo de Miopia depositou-se nesta manutenção da referência do

${ }^{111}$ MESZÁROS, István. Para além do capital. São Paulo: Boitempo, 2002, p. 919.

${ }^{112}$ MESZÁROS, István. Op.cit., p. 50. 
Estado como estrutura de controle, representado aqui, guardadas as devidas proporções, como a existência da direção teatral em sua vertente gerencial e antagônica ao restante do próprio grupo, mesmo que os discursos e a administração do processo criativo tentassem, constantemente, "reestruturações" em busca de uma superação de tal desigualdade. Ao contrário do que possa parecer, tal processo não gerou antagonismos ou crises insuperáveis, já que sua forma de gerenciamento surge exatamente para resolver e escamotear os conflitos, seja através do diálogo seja através da autoridade.

Em meio aos fracassos e destroços gerados por tal modo de produção de conciliações e reprodução de hierarquias, é possível perceber, no entanto, fissuras, linhas de fuga e desvios. Dentre as tentativas de superação surge, em diversos momentos do trabalho, um modelo de produção, realizado ainda de maneira irrefletida, que talvez tenha sido capaz de romper com esta estrutura hierárquica na criação. Preferi chamá-lo aqui de processo labiríntico de produção, não só para distingui-lo do seu par gerencial e colaborativo presente em outras etapas do processo de Miopia - já que ambos os momentos mantiveram as funções artísticas delimitadas -, mas também para marcar a sua dimensão constante de crise, seu caráter de produção de crise.

Este modo labiríntico não é visto aqui como sinônimo de um espaço coletivo transparente e paralisado em sua harmonia igualitária. Este processo não foi animado, parece-me, pela tentativa violenta ou negociada de purificação de toda opacidade do coletivo teatral, mas foi realizado em nome precisamente da irredutibilidade dos antagonismos que fundam a experiência do político em geral, e de qualquer agrupamento artístico. Pensar e praticar um modo de produção capaz de suportar as consequências de antagonismos que não se deixam - e não devem se deixar - apagar é uma tarefa que a construção de Miopia revela de forma desigual e inconstante, mas presente:

O caráter comunal de produção faz, desde o início, do produto um produto comunal, geral. (...) Neste fundamento (comunal), ele (o produto) é postulado como tal antes da troca; isto é, a troca de produtos não é de maneira alguma o meio pelo qual a participação do indivíduo na produção é mediada. A mediação deve, claro, ocorrer, mas de outra forma. (...) No caso comunal (...) o trabalho do indivíduo é posto desde o início como trabalho social. Assim, qualquer que seja a forma material particular do produto que ele cria ou ajuda a criar, o que foi comprado com o seu trabalho não é um produto específico e particular, mas antes uma porção especial da produção comunal. Ele não tem, portanto, nenhum produto particular para trocar. $\mathrm{O}$ seu produto não é um valor de troca. $\mathrm{O}$ produto não tem que ser antes transposto a uma forma particular 
para atingir um caráter geral para o indivíduo ${ }^{113}$.

Seguindo o percurso apontado acima por István Mészáros, neste processo labiríntico de criação teatral não houve como mediação entre os produtores qualquer forma de troca entre produtos privados: entre o dramaturgo, o diretor e os atores não houve nestes momentos quem oferecesse o texto em troca de sua execução. Não houve negociação. A relação entre os produtores não foi mais mediada pela troca ou venda da força de trabalho. Entre diretor e atores, por exemplo, não houve mais quem oferecesse o processo de gestão e exigisse em troca a interpretação e execução de suas indicações. Mészáros fala do sistema comunal de produção como aquele em que há "a mediação dos membros da sociedade por meio da troca planejada de atividades, em vez da direção e distribuição política arbitrárias tanto da força de trabalho como da fetichista troca de mercadorias"114. Quando tal princípio esteve presente em Miopia, a relação entre os criadores teatrais não foi mais, portanto, mediada pela autoridade, mas sim pelo processo consciente de realização das próprias atividades criativas. Processos criativos em constante movimento foram assim intercambiados. Extinguindo-se deste processo o valor de troca, a relação entre os autores foi mediada apenas pelo material artístico que todos produziram e que não foi privatizado por nenhuma das funções. Todo o material proposto, mesmo que de forma individual, pôde ser testado, avaliado e recriado coletivamente, fazendo da experiência a última palavra sobre a validade de uma ideia ou cena. Este princípio está presente também no modo colaborativo de produção:

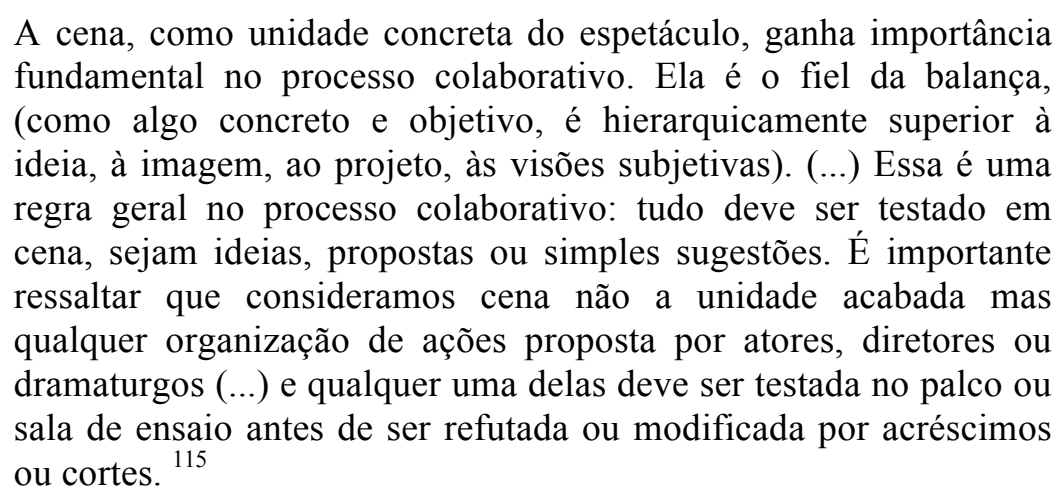

No entanto, durante seus relampejares labirínticos, o processo de construção das cenas, que ocuparam posição de primazia nestes momentos de trabalho, assim como nos

\footnotetext{
${ }^{113}$ MÉSZÁROS, István. Op. cit.,p. 875.

${ }^{114}$ MÉSZÁROS, István. Op.cit., p. 1023.

${ }^{115}$ ABREU, Luís Alberto de. Op. cit., p. 39.
} 
fala Abreu, foi organizado sob uma divisão do trabalho diferente daquela presente nos processos colaborativos (tal como os caracterizamos até agora). Diferente de um processo em que “ é vedado a um criador assumir as funções do outro”, mesmo que haja uma invasão mútua entre as funções, nesses relâmpagos labirínticos presentes na criação de Miopia, a organização do trabalho encontrou-se dividida de uma forma própria à utilizada por Marx e Engels para caracterizar a produção comunista:

$\mathrm{Na}$ sociedade comunista, onde cada um não tem um campo de atividade exclusivo, mas pode aperfeiçoar-se em todos os ramos que lhe agradam, a sociedade regula a produção geral e me confere, assim, a possibilidade de hoje fazer isto, amanhã aquilo, de caçar pela manhã, pescar à tarde, à noite dedicar-me à criação de gado, criticar após o jantar, exatamente de acordo com a minha vontade, sem que jamais eu me torne pescador, caçador, pastor ou crítico. ${ }^{116}$

Durante esses momentos do processo, atores, técnicos de luz, cenotécnicos e iluminador puderam cambiar suas funções. As propostas de improvisação e de exercícios inseriam todos estes participantes em todas as funções e os provocavam a trocar constantemente de atividade, sem que, durante esta etapa labiríntica, se pudesse definir a área de ação de cada um. Assim, os atores aprenderam com os técnicos a manejar cabeamentos, lâmpadas, materiais de cenário e de figurino e montavam juntos as estruturas técnicas de cada improvisação e de cada cena. A divisão entre trabalho manual e intelectual surgia superada, já que se os atores também montavam a instalação técnica, os técnicos foram responsáveis por criar conceitos de luz, de cenário, de figurino e por atuar durante muitas improvisações e exercícios, em um espaço que oscilava entre o personagem e o iluminador, o personagem, participante da narrativa (como coro ou trabalhadores, por exemplo) e o próprio técnico executando tarefas técnicas em cena. Esta estrutura estendeu-se durante toda a temporada de Miopia, já que os técnicos de luz e de cenário estavam em cena e os atores montavam as estruturas e o aparato técnico de suas cenas, participando, quando o espetáculo terminava, também da desmontagem. Tal superação da divisão entre trabalho manual e intelectual trouxe para os atores uma compreensão maior da estrutura geral da peça, bem como habilitou-os a propor cenas com maior elaboração de todas as dramaturgias, já que puderam unir o projeto criativo à sua execução. Para os técnicos, estes momentos labirínticos trouxeram uma participação criativa no processo, contribuindo para as cenas com outros pontos de vista, de quem participava do processo a partir de visões distintas sobre a narrativa,

\footnotetext{
${ }^{116}$ MARX, Karl e ENGELS, Friedrich. A ideologia alemã. São Paulo: Boitempo, 2007, p. 38.
} 
sobre os personagens e, principalmente, sobre a estrutura espacial da Usina de Compostagem como espaço cênico.

Chamamos este processo de labiríntico e não de comunista devido a algumas contradições. Havia o intercâmbio entre todas estas funções, que perderam suas delimitações, mas não havia este rompimento com relação aos trabalhos de dramaturgia e de direção. Eu permaneci, mesmo durante estes relâmpagos, como diretor e dramaturgo único do trabalho, sendo responsável por definir a encenação e o texto final a partir de cada proposta apresentada pelo coletivo de criadores. Isto gerou um processo de criação em que os impasses e dificuldades eram vistos de cima, por um único integrante do grupo, que, de fora do labirinto, guiava os demais a partir de seus traçados, rumo às suas tentativas de saída. Como, no entanto, eu não participava desse intercâmbio criativo, não conseguia enxergar com nitidez novas possibilidades de saída, por mais que visse o labirinto de fora e, teoricamente, fosse o responsável por guiar os percursos de todos. Assim, a aparência labiríntica da forma final da peça talvez deva muito a esta coexistência de modos de produção conflitantes, à presença de criadores capazes de superar suas especializações e as fronteiras entre trabalho manual e trabalho teórico em coexistência com um diretor e dramaturgo inserido neste processo de maneira antagônica e especializada.

No entanto, esse processo era muito mais veloz e criativo do que eu podia ser, como criador. As soluções que eu poderia dar, estando nesta posição aérea sobre o labirinto, eram sempre inferiores ao que a concretude das propostas dos outros artistas, em labirinto, propunham. Assim, eu que deveria definir a encenação e as possíveis mudanças do texto, cedia minha própria voz e última palavra sobre cada cena às próprias cenas, no que era acompanhado pelos demais artistas: isto significa dizer que cada material criativo, emergindo seja como esboços de cenas e de personagens, seja como propostas de luz e de cenário, só pôde ser substituído por outro material criado e não pelas propostas e definições externas dadas pelos responsáveis por cada dramaturgia. O processo de criação e seleção conjugou assim a teoria e a prática, a ação e a reflexão, distanciando-se das infinitas discussões em assembleias, ligadas à prática do processo coletivo de criação que esteve muitas vezes presente em Miopia, e também da combinação sócios colaboradores/acionista majoritário que marcou a hierarquia do processo colaborativo empregado durante a criação da peça. Veremos adiante se tal reflexão pode ser desenvolvida a partir do estudo da criação de dois fragmentos da peça.

Antes disso, vale lembrar que já mencionamos a importância do conceito de 
encenação para o projeto e a materialização das dramaturgias em Miopia. Mas, durante os momentos que marcaram este processo labiríntico de criação, em que não havia a palavra final do diretor, como se definiu a encenação, a articulação dos diversos elementos que formaram os conceitos do espetáculo teatral? Vimos também que em tais conceitos, no lugar do único olhar vetorizado do encenador, encontram-se materiais em constante rotação, um conjunto de imagens e sons dados como uma coralidade, em que todos os elementos da representação surgem sem hierarquia pré-estabelecida. Se não estivermos errados, esta ausência de hierarquia esteve relacionada não à intenção individual do diretor, mas ao modo de produção labiríntico, em que a sobreposição de vozes de todos os criadores, em um processo sem horizonte fixo definido, realizou inúmeras totalizações provisórias, recriadas constantemente, mesmo durante a temporada da peça. No transcorrer deste processo em que diversas visões sobre uma mesma cena ou conceito, sugerido ou provocado pelo diretor, foram apresentadas sob a forma de improvisação, o conceito de encenação, responsável por articular os elementos em uma totalidade, sofreu modificações constantes, em um movimento de conservação e negação contínuas. Coube ao meu trabalho como encenador formular procedimentos para que os criadores fossem estimulados constantemente a dar suas visões acerca das questões que eu identificava no processo de criação, conduzindo os materiais surgidos a partir de ideias e pressupostos artísticos que eram sempre reformulados para suportar esta prática e não para condicioná-la.

\section{II.2. Coro e alarido}

\section{ANIVERSÁRIO DO CINEMA. O TRABALHO.}

Johansen conduz o público para debaixo do tubo de lixo. Operários trabalham nas máquinas pesadas que movem o projetor de imagens do cinema. Maribel no camarim, em frente ao boneco de Mércia, que está coberto com um cartaz da Escrava Zuzu.

MARIBEL - Espelho espelho meu

Como se compra um rosto

Sem buracos como os meus?

MÉRCIA - Você nunca mais venha me falar em greve do olhar, em maldição das imagens!

MARIBEL - Eu preciso desta oportunidade.

Você está cansada de saber, não finja alarde.

Ou você se recusou a projetar o cinema? 
Ou você pensava que a vida com o cinema seria um poema?

A vida que você criou para você e para o mundo é um poema rasgado

Escrito sem letras e sem música, com cadeados no lugar dos versos.

Então não me venha falar de honestidade.

MÉRCIA - Honestidade? Eu vou arrancar essa palavra da sua boca! Uma vadia! Que vende o corpo e os ideais para ficar rebolando em cima de um palco! O cinema não trouxe nada que já não fosse vendido nesta cidade.

MARIBEL - Eu não vendi nada.

Só estou aqui trabalhando e me doando.

Política não interfere no meu trabalho. Sou uma profissional. Como você.

Vim aqui para fazer um show de cultura brasileira,

E me orgulho da minha luta sem fim pelo país e por mim.

Eu sou a prova viva do sonho e minha vida é um sonho inteiro.

Eu quero que cada um me compre e me imite, não sou um exemplo Mas posso ser, na vida de cada um, um palpite.

MÉRCIA - Que bom. Eu pelo menos vou ter sempre a consciência tranquila.

MARIBEL - Eu vim trazer para esses trabalhadores uma mensagem de esperança

Uma mensagem de que é possível ver a vitória em nossa silhueta

Que o Brasil rima com anil e com vitória

Eu vim mostrar que é possível tirar o Brasil da gaveta!

MÉRCIA - Consciência tranquila! Consciência tranquila!

MARIBEL - Fala baixo. Fala bem baixo. Muito baixo.

Você não vai estragar a minha missão de cura.

$\mathrm{Na}$ frente do Belmiro você quer criar a minha sepultura.

Ele é o presidente da sociedade dos amigos do Cinema, agora.

MÉRCIA - Que nojento! Fundaram uma sociedade de novos ricos, só para tirar mais dinheiro dos espectadores!

Belmiro entra, e começa a mostrar tudo a Mércia e Maribel.

BELMIRO - E, enfim, os bastidores! No aniversário do nosso cinema, é importante dizer que sem estes homens corajosos as imagens não existiriam! Sem o suor destes anônimos, o maior projeto cultural e social da história desta cidade não aconteceria! São eles, com seu trabalho concreto, os responsáveis pelo voo etéreo das imagens que encheram nosso cotidiano de encanto e revolucionaram a vida nesta cidade de puro sonhar!

OPERÁRIO - Ai! Ai!(É recolhido por um homem de preto. Outro assume o seu lugar.)

MÉRCIA - O que foi isso? Coitado do rapaz...

BELMIRO - Um acidente de trabalho. Acontece, algumas vezes. Por isso todos os nossos trabalhadores têm seguro saúde. Aquela máquina em que ele trabalhava deve orgulhá-lo muito: é a principal máquina do nosso cinema. $\mathrm{O}$ trabalhador posiciona as suas costas sobre a plataforma e um delicado alfinete de aço traça sobre suas costas a imagem a ser projetada. A vida do trabalhador é transmitida, via sangue, suor e pus, para o projetor, dando vida às 
imagens!

MARIBEL - É violento. Mas bonito.

BELMIRO - São os bastidores do desenvolvimento. Tudo parece miraculoso, até que se conheça a fundo as estruturas!

Um operário morre na máquina e é substituído por outro. (...)

\section{A GREVE DO OLHAR}

Debaixo do tubo de lixo. Cinema. Matos, com uma câmera, está filmando tudo. Uma assembleia. Trabalhadores nas pesadas máquinas de projeção de imagens, não param de trabalhar mesmo enquanto a Assembleia ocorre.

ROSA - Vocês não entendem? Apenas parar de trabalhar não adianta. Eles nos mandam embora e contratam outros no nosso lugar. Não é o nosso trabalho que produz as imagens, é o olhar das pessoas. Se todos pararmos de olhar, as propagandas perdem o seu valor. Se todos pararmos de olhar, os preços vão cair, o cinema vai fechar, os capitalistas vão todos quebrar! Sem as imagens não há realidade, não há cidade, não há mundo! Companheiros: é hora de atitude. (Coloca uma venda nos olhos) Trabalhadores colocam as vendas e trabalham de olhos vendados. Um operário grita, preso em uma das máquinas. Continuam a trabalhar como antes, só que agora vendados.

CORO DOS GREVISTAS DO OLHAR - Sejamos todos cegos.

As imagens percorrem o ar feito praga de gafanhotos

Feito nuvens de tempestade, feito vaga-lumes radioativos

Sejamos todos cegos.

As imagens nos colonizam, da medula às atitudes,

Do coração ao inconsciente, o que há de mais íntimo em cada um

Está contaminado feito pão embolorado.

Sejamos todos cegos. Sejamos todos cegos.

A cor das propagandas não nos arrasta mais

O negro do ódio suja agora o arco-íris

Hipnose das Imagens. Rosa é presa por Matos, depois que ele desliga a câmera. O coro assiste a tudo, com medo.

CAMELÔ - Venda! Venda! Compre! Compre a exclusiva venda da Greve do Olhar! Comece a Greve na moda! ${ }^{17}$

As cenas acima situam-se em um momento de interrupção na fábula de Miopia: após sucessivas mudanças espaciais, ocorridas em velocidade vertiginosa, contadas em poucas cenas (expulsão de desempregados de São Paulo; fundação sangrenta de uma cidade utópica, chamada de Miopia, no Mato Grosso; inauguração de um cinema de comerciais na cidade), o público era deslocado para um pátio externo da Usina e as

117 ALMEIDA, Ligia Marina; DELMANTO, Ivan; FARIA, Fernanda, et al. Miopia. Inédito, 2006, p. 2631. 
cenas ocorriam em um tempo arrastado, com o público sentado em arquibancadas debaixo de dois gigantescos tubos de dilaceramento de lixo. Sob o primeiro tubo, do lado direito, o público participava da comemoração do aniversário do cinema de comerciais. Sob o segundo tubo, como um reflexo do primeiro, só que do lado oposto, a ação central da cena visava interromper a trajetória progressiva ocorrida até aquele instante e o público era, ao invés de conduzido, freado, assaltado em meio ao seu percurso, obrigado a parar, a sentar nas arquibancadas e bancos sujos e a aderir à Greve do Olhar. O local escolhido para a realização da segunda cena, no entanto, reproduzia exatamente a mesma tubulação e estrutura de máquinas em que, na cena anterior, apresentava-se a celebração do cinema de comerciais. Assim, a estrutura espelhada da Usina de Lixo parecia dizer que a comemoração do cinema de comerciais e o movimento pela sua destruição eram estranhamente iguais. Durante o processo de criação das cenas, o problema central encontrado pelo grupo girou em torno da representação do trabalho, ação fundamental às duas situações citadas acima: "Como fazer o trabalho na cena? Propusemos bater martelos nos tubos mas vimos que não funcionou. O trabalho deveria ser uma tortura. Mas como fazer alguém trabalhar sem ser de maneira maquinal, meio antiga, meio Tempos Modernos? "118

A questão relatada por uma das atrizes do grupo, que chega a mencionar o filme de Charles Chaplin, aponta a dificuldade que se apresentava aos criadores que, naquele momento, percebiam não encontrar repertório formal suficiente para dar conta das novas relações de trabalho contemporâneas. Tais relações já não "funcionavam" sob a formalização do realismo épico, capaz de apresentar o trabalho fabril da segunda revolução industrial mas incapaz de expressar a produção de valor realizada sob os paradigmas do trabalho imaterial, objetivo que o grupo havia se colocado na construção das duas cenas:

Nosso cronograma de leitura atrasou porque tivemos dificuldades para ler e entender o texto da Isleide Fontenelle. Discutimos por três dias seguidos e depois fomos tentar improvisar as cenas do aniversário do cinema e da greve do olhar. Sabíamos o que tínhamos que fazer, mas não sabíamos como. Deu desespero. ${ }^{119}$

O cronograma de leitura mencionado por Estefânia retrata o modo como o

\footnotetext{
118 LOPES, Estefânia. Questões de interpretação: relato de pesquisa. In: ALMEIDA, Ligia Marina; FARIA, Fernanda; DELMANTO, Ivan, et al. Anjos do desespero. Relatório da terceira etapa de pesquisa. Apresentado à Secretaria de Cultura do Município de São Paulo, 2006, p.45. Inédito. Disponível para consulta na Divisão de Fomento da Secretaria Municipal de Cultura.

${ }^{119}$ Idem, ibd.
} 
processo estava sendo organizado no instante em que a crise na montagem dessas duas cenas emergiu: o texto já havia sido criado, a partir de improvisações realizadas de maneira realista, em que trabalhadores apareciam carregando ferramentas e com macacões que lembravam as encenações futuristas de Meyerhold. No entanto, após a realização de um ciclo de leituras sobre o trabalho contemporâneo, em que o livro de Isleide Fontenelle, $O$ nome da marca, foi lido e discutido exaustivamente por todo o grupo, as versões improvisadas das cenas já não faziam mais sentido, já apareciam para todos imersas em um universo antigo, incapazes de plasmar o que chamávamos de "trabalho do olhar":

Descobrimos durante o projeto de pesquisa que hoje a própria forma valor se metamorfoseia. (...) O trabalho produtor de valor torna-se imaterial, independente do tempo e do espaço. A noção de trabalho imaterial engloba tanto o operário qualificado cuja personalidade se tenta controlar quanto o conjunto das figuras sociais (trabalhadores precários, desempregados, jovens operários, estudantes, estagiários...) que constituem o lado sujo do paradigma baseado na comunicação e na imaterialidade. Se tempo de vida e tempo de trabalho passam a constituir uma única e mesma realidade, o trabalho social é difundido, e não diminui, ao contrário do que frequentemente nos diz o discurso ideológico. A criatividade, o consumo, a alma e até mesmo o olhar passam à esfera produtiva, agregando valor às mercadorias. Toda dimensão da vida configura-se agora como (sobre)trabalho produtivo. Eugênio Bucci observa que a atividade ingênua de dar um passeio num shopping center ou assistir aos comerciais na TV converte-se em trabalho; o olhar do consumidor, que registra as imagens das marcas bombardeadas a todo instante, gera valor, já que a força de uma marca é determinada por sua difusão social. ${ }^{120}$

Esta intenção conceitual, entretanto, não conseguia mover o processo de criação das cenas. $O$ trabalho de encenação nessa etapa consistiu em estimular e aprofundar a crise, ao invés de tentar qualquer solução artística conciliadora: "Quando não conseguíamos criar o sofrimento era grande. E parecia que os ensaios vinham para a gente ficar mais em crise do que já estava. Era meio masoquista: todos traziam estímulos para a crise e não para resolver. Parecia que não ia dar certo."121

Algumas pistas surgiram quando trouxe para a equipe de iluminação o chamado "Fragmento sobre as máquinas", trecho dos Grundrisse, de Marx. Por sua complexidade teórica e por sua importância no processo de criação das cenas, vale citá-lo de forma extensa:

${ }^{120}$ DELMANTO, Ivan. Conceito de encenação. In: ALMEIDA, Ligia Marina; FARIA, Fernanda; DELMANTO, Ivan, et al. Miopia - Programa do espetáculo. Inédito, 2006, p. 5.

${ }^{121}$ LIEGEL, Juliana. Entrevista dada ao documentário Miopia. Direção e roteiro: André Moncaio, 2006. 
A troca de trabalho vivo por trabalho objetivado, quer dizer, a manifestação do trabalho social sob a forma antagônica de capital e de salário, é o último desenvolvimento da relação de valor e da produção baseada sobre o valor. A premissa desta relação é que o conjunto de tempo de trabalho imediato, a quantidade de trabalho utilizada, representa o fator decisivo da produção de riquezas. Sem dúvida, na medida em que a grande indústria se desenvolve, a criação de riquezas depende cada vez menos do tempo de trabalho e da quantidade de trabalho utilizado e cada vez mais do poder dos agentes mecânicos que se põem em movimento durante o trabalho. A enorme eficiência destes agentes, não tem, por sua vez, nenhuma relação com o tempo de trabalho imediato que custa sua produção. Depende mais do nível geral da ciência e do progresso da tecnologia ou da aplicação desta ciência à produção (general intellect). (...) $\mathrm{O}$ homem se comporta como um supervisor ou regulador da produção. (...) Em uma palavra, o desenvolvimento do indivíduo social representa o fundamento essencial da produção e da riqueza. (...) A partir do momento em que o trabalho, sob sua forma imediata, tem deixado de ser a fonte principal da riqueza, o tempo de trabalho deixa e deve deixar de ser sua medida, e o valor de troca deixa pois também de ser a medida do valor de uso. (...) Produz-se então o livre desenvolvimento das individualidades. (...) Trata-se de reduzir a um mínimo o trabalho necessário da sociedade. Esta redução implica que os indivíduos recebam formação artística, científica etc, graças ao tempo liberado e aos meios criados em benefício de todos ${ }^{122}$.

Este processo descrito por Marx criaria as condições para a emergência de uma nova individualidade, ao mesmo tempo plenamente socializada e voltada para o desenvolvimento de suas múltiplas aptidões. Seria este indivíduo social, que se autodesenvolve de maneira ilimitada, o produto do que Marx chama de General Intellect: a inteligência socializada aplicada à produção liberta a coletividade do trabalho, para que possa recuperar seu tempo de vida fruindo da totalidade da riqueza social. Havia, no entanto, outras leituras possíveis (e antagônicas) desta emergência da intelectualidade pública como produtora de valor. Tais leituras foram significativas no embate com a crise da representação do trabalho que a encenação da peça experimentava naquela etapa. A primeira dessas interpretações é dada pelo próprio Marx que no manuscrito realizado em 1864, que constituiria o capítulo VI do Livro Primeiro do Capital, considera que:

O desenvolvimento do poder produtivo do trabalho socializado, em oposição ao trabalho mais ou menos isolado do indivíduo, etc., e, juntamente com isto, a aplicação da ciência, este produto geral do desenvolvimento social, ao processo de produção direta, tem a

\footnotetext{
122 MARX, Karl. Los fundamentos de la critica de la economia politica, tomo 2. Madrid: Alberto Corazon, 1977, p. 202- 203.
} 
aparência de um poder produtivo do capital, não do trabalho, ou aparece apenas como um poder produtivo do trabalho enquanto idêntico ao capital, e em qualquer caso não aparece como o poder produtivo seja do trabalhador individual, seja dos trabalhadores reunidos no processo de produção. A mistificação subjacente à relação-de-capital em geral é agora muito mais desenvolvida do que era, ou poderia ser, no caso da subsunção meramente formal do trabalho sob o capital ${ }^{123}$.

Sob tal ponto de vista marxiano, tal intelectualidade pública seria mais uma força produtiva sob controle do capital, algo que o trabalho do olhar e a difusão social das marcas comprovaria.

A segunda interpretação surge com Antonio Negri que, ao contrário do fragmento de Marx citado acima, vê em uma possível recusa do trabalho, exercida pelo trabalhador e possibilitada pela redução da quantidade de trabalho socialmente necessária (graças ao avanço da ciência), o caminho da liberação e do comunismo. $\mathrm{O}$ novo sujeito social criaria para si uma nova forma de poder que, não mais sustentada no valor de troca e na representação, abrir-se-ia para a perspectiva da autovalorização expansiva e coletiva. Deste modo, diante de um novo modo de produção, a perspectiva de disputa pelo controle do aparelho de Estado, através de instrumentos representativos como partidos e sindicatos, ao que parece, não mais se colocaria, pois a autovalorização tenderia à auto-organização comunal.

A montagem das duas cenas antagônicas e espelhadas teve como objetivo inicial abarcar essas duas interpretações contraditórias do conceito de general intellect: se na cena da inauguração do cinema esta difusão imaterial do trabalho estaria a serviço da produção de mercadorias, os grevistas do olhar da cena seguinte, em sua recusa ao trabalho do olhar, estariam ligados a possíveis formas de emancipação social.

O "Fragmento sobre as máquinas" foi então estudado e transformado, pela equipe de iluminação, em uma instalação:

19/11/2005 - Ensaio na instalação proposta por André a partir do texto do Marx sobre o G.I. Pequenas lâmpadas dicroicas no fundo das máquinas. Luz fantasmagórica que vem debaixo das máquinas. Pedaços do texto de Marx impressos em papel branco por todo o espaço. Algumas lâmpadas, com luz negra, transformam o branco do sulfite em uma cor ainda mais fantasmagórica. Eliseu com o corpo cheio de pequenas lâmpadas em cima do tubo: não

\footnotetext{
123 MARX, Karl. Economic Manuscripts 1861-64: Draft Chapter 6 of Capital. In: Marx- Engels Collected Works. v. 34. Em http://www.marxists.org/archive/marx/works/1864/economic/index.htm. Consultado em 12/12/2010.
} 
funcionou. O melhor foi ocupar embaixo, o subterrâneo, o buraco embaixo do lixo. A proposta para o outro lado não funcionou. $\mathrm{O}$ ideal seria criarmos espaços exatamente iguais, para as duas cenas. Lígia usou uma grande agulha de crochê como instrumento de trabalho. Pareceu interessante, mesmo que não saiba por quê. ${ }^{124}$

Durante o processo de criação de Miopia, a regra para todos os participantes era buscar o tempo todo apresentar as ideias em sua materialização prática, transformada em dramaturgia. Quando tal regra funcionava de fato, a mediação da direção como estrutura de controle podia ser prescindida, dando ao processo de criação sua feição socializada. Assim, a instalação proposta por André e Eliseu, iluminador e técnico de luz, respectivamente, procurava expressar o que haviam concluído sobre o estudo das relações de trabalho. A presença do texto de Marx na instalação, graças à luz negra, ganhava uma cor rosa tão fantasmática que estimulou os atores, durante o exercício que fizemos explorando o espaço da instalação, a explorarem ações físicas estranhas, que deformavam seus corpos o tempo todo. A luz vinda de baixo contribuía para dar uma visualidade ainda mais distorcida aos movimentos dos atores. Ao final do exercício, sentamos todos juntos para discutir: "Decidimos utilizar apenas em baixo do tubo. Caiu a proposta do Eliseu em cima do tubo. Decidimos usar apenas a instalação da direita. A da esquerda caiu. Serão dois espaços espelhados, idênticos. Amanhã nova proposta da luz." "125

Coletivamente, após a experimentação e o teste prático, algumas propostas foram selecionadas e outras descartadas. Sem negociação, sem votação ou palavra final do diretor ou de outro criador sobre a validade ou não de cada proposta. O critério para a manutenção, descarte ou alteração de uma ação, imagem ou material criado era a pertinência da utilização de cada componente, durante as improvisações e exercícios, em relação aos conceitos em investigação. A pertinência não era julgada externamente, mas através da crítica coletiva efetuada imediatamente após cada exercício, analisandose o que foi experimentado na prática, em longas reflexões conjuntas. Este trabalho crítico era executado em roda, procurando, ao invés do julgamento acerca da qualidade artística do que fora realizado, detectar aspectos eficazes relacionados aos temas pesquisados em cada etapa de trabalho. Minha função como diretor e dramaturgo neste processo, na maior parte das vezes - mesmo ainda sendo o responsável por zelar pela rigidez dos pactos disciplinares coletivos -, não era a de gerir o processo de tomada de

\footnotetext{
${ }^{124}$ DELMANTO, Ivan. Caderno de direção - 2005. Inédito, 2005, p. 89.

125 Idem, ibd.
} 
decisões mas consistia em provocar - com conceitos, perguntas, possíveis direcionamentos, sugestões de critérios críticos e com a realização de exercícios, de pequenas encenações e de propostas de texto - caminhos bastante diversos para cada ator e para cada cena. O teste e experimentação contínua sobre cada caminho revelava, para todos os participantes e não só para mim, nas cenas e experimentos esboçados, quais perguntas deveriam ser respondidas e quais deveriam permanecer apenas formuladas. No entanto, como a contradição constante é o único critério absoluto, propostas descartadas e vozes dissonantes eram estimuladas a serem novamente apresentadas, buscando a diferença, a criação de percursos distintos e simultâneos.

No dia seguinte, Eliseu continuou propondo a imagem de um ator em cima do tubo, coberto por pequenas luzes. Este espaço de contradição, de possibilidade de experimentar caminhos contrários simultaneamente, a partir não do desejo ou do personalismo de cada criador, mas da concretude de diversas materializações cênicas sendo sobrepostas durante o processo de ensaio, forneceu-nos algumas pistas para a representação das novas relações de trabalho. Cada pista emergiu desta sobreposição de percursos, propostas e dramaturgias e não da opção por um determinado aspecto ou outro. É claro que, com o tempo, diversas decisões são tomadas e solidificadas, mas sempre após uma seleção que se efetiva dentro da própria montagem das cenas, a partir da afirmação da diferença e não de sua exclusão. Tal processo alimenta crises constantes, já que por muitas vezes o grupo vive a sensação de não estar caminhando para lugar algum. O desenvolvimento acontece, mas não de maneira linear já que, como vimos na descrição acima, muitas vezes uma única cena é ensaiada e experimentada sobrumos e conceitos totalmente contraditórios, testados ao mesmo tempo. O aspecto de acúmulo de ruínas, presença formal constante em todos os aspectos da encenação de Miopia, tem relação estreita com este percurso de justaposição e colagem constantes, fazendo com que, no entanto, a fusão dos elementos não apague suas diferenças iniciais mas conserve expostas as suas cicatrizes.

Experimentamos uma agulha coberta por sulfite. Daniel trabalhou com a agulha trazida pela Lígia no outro dia. A luz negra transformava a agulha em um objeto imaterial. Maribel aparecia "segurando" a luz, em uma ideia mais interessante do que a anterior, em que Eliseu aparecia coberto por pontos iluminados. ${ }^{126}$

Durante o ensaio da cena, a avalanche de propostas testadas acabou nos apresentando, em seu atrito e dilaceramento mútuo, uma sobreposição de dramaturgias 
que nos revelou uma possibilidade para uma representação alegórica do trabalho: as ações deformadas realizadas por um dos atores (dramaturgia do ator), no buraco debaixo do grande tubo (dramaturgia do espaço) manipulando uma agulha iluminada (dramaturgia do espaço, do figurino, da iluminação), utilizando-se de ideias trazidas em contextos diferentes, por vários criadores.

O dançar da agulha iluminada traçava desenhos pelo espaço que lembravam os luminosos de neon comuns em casas noturnas. Um dos cenógrafos propôs que trabalhássemos com luzes de neon. O neon não funcionou nessa cena, já que atrapalhava o efeito da luz negra, mas foi retomado em um contexto distinto, iluminando o espelho do quarto do catador de lixo Johansen, como uma cicatriz de sua antiga participação na indústria cultural. Importante assinalar que o efeito espectral das ações envolvendo a agulha era causado não por um aparato tecnológico sofisticado, mas pela junção do instrumento com a folha sulfite e a luz negra. Esta precariedade, baseada em materiais usualmente descartáveis, caracterizou toda a encenação de Miopia. A partir da agulha iluminada surgiu a ideia de retomar a máquina que no conto $A$ colônia penal, de Kafka, desenhava feridas nas costas dos condenados.

Assim, o trabalho passou a ser representado nas duas cenas a partir da alegoria de uma espécie de máquina do trabalho: um dos funcionários do cinema deitava-se de costas, debaixo do tubo de lixo e em cima de um enorme parafuso, para que seu parceiro, de posse de uma grande agulha fantasmática, desenhasse em suas costas. A cena do aniversário do cinema, citada acima, consistia em demonstrar este mecanismo de trabalho, em um procedimento tipicamente épico:

\begin{abstract}
Aquela máquina em que ele trabalhava deve orgulhá-lo muito: é a principal máquina do nosso cinema. $\mathrm{O}$ trabalhador posiciona as suas costas sobre a plataforma e um delicado alfinete de aço traça sobre suas costas a imagem a ser projetada. A vida do trabalhador é transmitida, via sangue, suor e pus, para o projetor, dando vida às imagens! ${ }^{127}$
\end{abstract}

Nesta cena, Maribel é contratada para fazer um show na inauguração do cinema de comerciais da cidade. O cinema só exibe reclames, filmes há muito abandonados nos Estados Unidos e que são descartados e comprados pelo prefeito da cidade de Miopia. Belmiro, antigo militante do PCB e agora empresário, é sócio da prefeitura neste que é o

\footnotetext{
${ }^{127}$ ALMEIDA, Ligia Marina; DELMANTO, Ivan; FARIA, Fernanda, et al. Miopia. Inédito, 2006, p. 27.
} 
grande projeto cultural da cidade. A cena começa com o diálogo de Maribel e sua mãe, Mércia, nos camarins. Apesar de ter sido contratada como arquiteta do cinema, Mércia não aceita os filmes de comerciais que, naquele instante, passam a povoar todo o espaço da cidade, por meio de cartazes, outdoors e jingles, em uma colonização e vitória absolutas do espetáculo. Maribel, que no texto fala em versos e no seu registro de interpretação era representada pela atriz a partir de todos os modelos tradicionais das heroínas trágicas (identificação das emoções e sentimentos da atriz com os da personagem, construção do papel por meio da memória emotiva e da gênese da personagem), tem sua voz povoada pelos ditames do espetáculo: a nação, o trabalho, a venda da imagem e o sucesso pessoal colonizam suas frases como se fossem slogans publicitários. A partir de exercícios e de um treinamento físico inspirado em Meyerhold, sem abandonar a identificação com o personagem, a atriz criou um corpo e uma partitura de ações não realistas, grotescas: ao mesmo tempo em que a dançarina fala o tempo todo em fazer sucesso com sua beleza, o corpo da atriz estava em cena deformado. A imagem que inspirou a construção de tal corpo foi a do labirinto, um corpo que não fosse capaz de se enquadrar nos ditames de beleza, proporção e harmonia da indústria cultural mas que, exatamente por isso, constituísse a falha trágica da heroína. Como se a voz do espetáculo, que habita e constitui o discurso de Maribel, fosse constantemente desmentida por seu corpo.

Quando Belmiro interrompe o show, a leitura de um poema de Carlos Drummond de Andrade acompanhada da dança erótica de um corpo deformado, os bastidores do cinema revelam literalmente o que está por trás do espetáculo. A máquina que perfura os corpos dos trabalhadores para, com o sangue, projetar as imagens dos comerciais, revela relações de produção, as mais violentas e precárias, criando o mundo etéreo das imagens. A encenação, com atores deitados nas engrenagens de enormes tubos que eram responsáveis na Usina pela trituração do lixo, montava com o texto dos personagens uma imagem de horror: os imensos tubos pareciam esmagar os corpos em cena. Apresentar um cinema de comerciais neste espaço, por si só, conferia sentidos ao tema do espetáculo, ligando às imagens imateriais à concretude do mundo do trabalho.

Se a sociedade participa da produção de riqueza e se é cada vez menos possível distinguir as fases de produção das de consumo, o tempo de trabalho do tempo da vida, a cena buscava distanciar-se do tradicional dualismo que separa trabalho material e imaterial. A emergência da intelectualidade pública, e da valorização imaterial, não se deve à sua emancipação dos constrangimentos da produção material, mas sim à 
subsunção desta pelas atividades imateriais e, dessa maneira, à subsunção da sociedade inteira no processo de valorização. Esta concretização dada ao trabalho nas duas cenas parece sugerir uma descrença, em Miopia, na capacidade daquela libertação das forças produtivas, no "livre desenvolvimento das individualidades" em que acreditava Marx.

A alegoria apresentada pelo grupo procurava unir a produção das imagens (os comerciais do cinema) com o trabalho sangrento dos trabalhadores que, posicionados atrás da tela de projeção, através da mutilação do próprio corpo, literalmente davam vida às imagens. Chama atenção a opção do grupo por não mostrar durante a peça as imagens exibidas pelo cinema: o público acompanhava, o tempo todo, os efeitos e as causas, a produção e a circulação das imagens tornadas mercadorias. O foco, que poderia estar depositado em uma crítica sobre a mídia, sobre o consumo ou sobre a publicidade como virtualidade, recaía assim nas relações de produção capazes de transformar as imagens em mercadorias.

No entanto, o ponto cego da cena parece emergir em sua repetição, durante a Greve do Olhar. Como dissemos, apesar da situação narrativa e do texto serem distintos, a cena posterior era realizada exatamente com a mesma proposta de encenação: espaço do cinema, por trás das projeções, debaixo do outro grande tudo, os trabalhadores produzindo com "sangue, suor e vida" as imagens exibidas pelo cinema. Nesta cena, uma liderança comunista surgia em meio às máquinas para conclamar os trabalhadores e o público a aderirem à greve do olhar. Os funcionários mutilados aceitavam participar do movimento, vendavam-se para tornarem-se imunes às propagandas, mas sem deixar de trabalhar. O ponto de vista crítico da cena parece recair novamente sobre as relações de trabalho, procurando revelar o que há de produção material por trás das imagens. Assim, o movimento dos grevistas do olhar seria frágil e cairia no ridículo ao não conseguir opor-se às verdadeiras causas da opressão. A encenação reforçava este ridículo, já que o coro surgia como um coletivo atomizado: os atores diziam o texto de maneira desordenada e quase silenciosa, posicionados muito distantes um do outro no espaço. O número pequeno de atores escolhidos para representar o coro (dois, apenas) só acentuava o clima de desolação, de fragilidade da experiência coletiva e das reivindicações dos grevistas.

Já vimos que a transformação das forças de trabalho em General Intellect aconteceria pela emergência de uma intelectualidade em geral. Seria essa dimensão de massa e pública do intelecto que constituiria a concretização, no século XXI, da antecipação marxiana da crise da lei de valor, isto é, de uma situação em que "o produto 
deixa de ser criado pelo trabalhador individual imediato para ser o resultado mais de uma combinação da atividade social que da simples atividade do produtor". Ou seja, a partir do momento em que o fundamento principal da produção não é nem o trabalho imediato nem o tempo de trabalho, é a apropriação de sua força produtiva geral que vira o fundamento da produção e da riqueza. É, no entanto, unicamente no trabalho imaterial, figura historicamente determinada do General Intellect (do saber social geral, do saber como bem público), que é impossível separar o tempo de trabalho do tempo de reprodução. E exatamente este aspecto produtor do saber público que a cena procurara retratar durante o seu processo de criação, sendo construída, inclusive, a partir do estudo e da prática sobre o texto marxiano, desaparece da versão apresentada na peça.

O que na cena da inauguração do cinema ainda poderia ser lido como alegoria de um trabalho imaterial, uma agulha luminosa que traça feridas nas costas do trabalhador, na cena posterior desaparece, dando lugar ao ponto de vista de crítica ao trabalho material. O grupo não percebeu que talvez os grevistas do olhar não fossem tão ridículos assim. A ausência de contradição na encenação deste coro, a opção por demonstrar apenas a sua fragilidade, fez com que o componente de trabalho imaterial pesquisado durante a construção da cena desaparecesse. O que a encenação trata como ridículo é exatamente o General Intellect, o olhar, os sentidos, os corpos e o saber públicos que, neste estágio de valorização imaterial do capital, conferem valor aos produtos. Ao escolher o trabalho das agulhas (utilizando-se para isso de uma referência da modernidade, de Kafka, de um momento histórico marcado por outras relações entre capital e trabalho) como aspecto a ser ressaltado, a encenação não consegue dar conta desta imbricação entre trabalho material e imaterial que forneceria à peça o potencial crítico que os criadores pretendiam. Mas talvez haja nesta escolha, mais do que um equívoco na relação com conceitos econômicos e sociológicos, uma crise formal, que não conseguiu ser resolvida, mesmo com um processo de vasto levantamento de material artístico: como expressar as novas relações de trabalho, imateriais, com formas materiais, as dramaturgias teatrais? Mesmo se ressaltada pela encenação, a greve do olhar parece ainda insuficiente para expressar a emergência de um novo paradigma na produção do valor. Como suspender o modelo épico, referência na pesquisa do grupo, para plasmar conteúdos que este modelo não consegue tratar? Trataremos destas questões com maior atenção nos capítulos seguintes.

Por ora, a partir da descrição do processo criativo destas duas cenas, cabe ressaltar que quando este processo labiríntico ocorreu em Miopia, a luz, o cenário, o figurino, a 
atuação, a encenação e a dramaturgia constituíram uma expressão comum a partir do atrito e das contradições surgidas do choque entre a diferença de seus idiomas. $\mathrm{O}$ processo labiríntico de produção, ao contrário da forma específica em que os processos coletivo e colaborativo foram experimentados durante a criação da peça, assumiu assim o papel de estimular permanentemente tais crises, advindas de diferentes funções em diálogo, criando exatamente a partir de tal polifonia e de infinidade de crises, sem que os criadores buscassem resolver as crises mas, pelo contrário, o alarido de vozes dissonantes, estimuladas pelo procedimento das inúmeras versões sucessivas de improvisação, sob constante troca de funções, conferia movimento ao processo devido ao choque e ao dilaceramento mútuo das propostas apresentadas.

Este processo distinguiu-se por funcionar como feixe de contradições, como devir que se desenvolve através de olhares e testemunhos contraditórios, dados por criadores muito diferentes entre si, com inserções totalmente diferentes dentro de um mesmo fluxo criativo. Este sistema opõe-se aos momentos em que o processo de criação da $I I$ Trupe buscou a harmonia a todo instante, visão bastante comum a muitas das reflexões sobre o maior valor a que deve aspirar à atividade teatral compartilhada. Nem sempre o grupo conseguia experimentar integralmente as premissas descobertas durante esta etapa de trabalho labiríntico: por vezes, pressionados pela urgência em tomar algumas decisões, os atores e demais criadores esperaram que eu, como diretor, determinasse rapidamente a melhor escolha a ser seguida, o que fiz, nem sempre realizando as melhores decisões: nesses momentos, podemos identificar hoje regressões do grupo à sua maneira de experimentar o processo colaborativo. A experimentação labiríntica, entretanto, quando desenvolvida, procurava garantir que todos os criadores dispostos a compartilhar situassem-se de maneira não alienada no processo: a criação baseada nas improvisações e em uma pesquisa que se dava sempre sob vasto material, abordado prática e teoricamente, a partir dos pontos de vista individuais, procurava fazer com que o velho paradigma sobre a existência ou não de instâncias decisórias ("quem tem a palavra final", por exemplo) fosse superado. Se não estiver errado, o "coletivo" como abstração espiritual e ideológica desaparece quando se substitui o modelo da uniformidade pelo da diferença e pelo dissenso coletivo (dissenso não só de opiniões, mas de histórias de vida, de visões de mundo, de conhecimento intelectual tradicional, de participação no processo etc.). Nessas etapas em que pudemos experimentar um processo contraditório e múltiplo, a criação deu-se geralmente por contágio e cada decisão individual dos criadores (que permanecem em suas funções como atores, 
dramaturgo e diretor, mas que transitaram o tempo todo entre a prática dessas diversas atividades) esteve necessariamente baseada no material artístico levantado por cada um, individual ou coletivamente, e no percurso compartilhado.

Com a criação de texto e cena a partir das improvisações dos atores (com estímulos sugeridos pelos próprios atores, pelo diretor ou pelo dramaturgo), com a confusão deliberada de funções ao longo de todo o processo (que faz com que todos os artistas tenham plena consciência e ação em todas as fases da criação), com a plena e diversa participação de todos em todos os níveis do processo de tomada de decisões, observou-se durante alguns momentos do processo criativo de Miopia que os artistas envolvidos puderam realizar suas maiores necessidades com liberdade, mas não sem dificuldades, já que tal processo envolveu uma nova forma de sociabilidade.

A crise constante, de modos de produção, de formas artísticas, de relações subjetivas, de valores e de convicções tornou-se matéria do próprio processo criativo. Assim, a instância da crise pode ser percebida na forma, no conteúdo e no modo de produção presentes em Miopia, dando máscara e rosto ao labirinto. O que mais nos interessa é observar em que medida tal processo contribui para a forma artística do espetáculo criado e para a configuração, através da mediação estética, do mundo social relacionado à obra. Se a estrutura do labirinto é caracterizada pela multiplicidade de caminhos, o processo de construção de Miopia, ao dissolver a autoria única, estabeleceria um ensaio em devir capaz de dar vazão a inúmeras vozes, confundidas, como um alarido, como o coro dos grevistas do olhar. A forma teatral do espetáculo, que reúne não só as vozes de seus criadores, mas citações, paródias e pastiches de autores como William Faulkner, Bertolt Brecht e Samuel Beckett, simbolizaria um mundo em que a noção de indivíduo é substituída pela de consumidor, este caracterizado não mais por uma personalidade centrada mas por uma infinidade de desejos e impulsos. No entanto, também como o coro dos grevistas da cena acima, tais vozes são frágeis, muitas vezes inaudíveis ou expressas de maneira tortuosa e caótica, o que caracteriza a forma arruinada da peça e os excrementos do seu processo de criação, por vezes expostos, por vezes denegados pelas paredes do labirinto. ${ }^{128}$

\footnotetext{
128 Artaud aborda em muitos momentos de sua obra este conceito de excremento, que pode ser aproximado da noção de ruína empregada nesta dissertação: "Este século já não compreende a poesia fecal, a intestina desgraça, daquela Senhora Morta, que desde os séculos dos séculos sonda sua coluna de morta, sua coluna anal de morta, no excremento de uma sobrevivência abolida, também cadáver de seus eus abolidos (...) A alma, diz o corpo enterrado do ser, é aquilo que, focal para a sobrevivência do ser, cai, fecal como um excremento e se amontoa no excremento. (...) O nome desta matéria é caca,e
} 
caca é a matéria da alma cujos charcos vi como distribuíam diante de mim alguns caixões. O hálito dos buracos tem um centro, e este é o abismo Kah - Kah, o hálito corporal da merda, que é o ópio da sobevivência eterna. Toda a merda surgida do amontoamento de tantos caixões é um ópio arrancado da alma ainda não calibrada o suficiente no abismo de sua fecalidade, o focal de sua fecalidade. (ARTAUD, Antonin. Cartas desde Rodez. Madrid: Fundamentos, 1984, p.167) 


\section{Saída interrompida 3: polifonia, dissonância e desmoronamento no labirinto/Terceira crise}

Vê-se um trapeiro cambaleante, a fronte inquieta Nos muros a esgueirar-se como um poeta, E sem se incomodar com os guardas descuidosos, Abre o seu coração em projetos gloriosos.(...) Estes, que a vida em casa enche de desenganos, Roídos pelo trabalho e as tormentas dos anos, Derreados sob montões de detritos hostis, Confuso material que vomita Paris. ${ }^{129}$

\section{1. Labirinto de vozes: Brecht, Stanislavski, Artaud e Beckett - início do desmoronamento}

Em um fragmento que tem o nome sugestivo de "É possível fazer teatro épico em qualquer lugar?", Bertolt Brecht responde à pergunta do título negativamente. Para Brecht, o teatro épico estaria ligado à experiência histórica do movimento operário europeu e o seu avanço formal só poderia ser compreendido por um público de “especialistas". Especialistas na luta política dos dominados, vanguarda política a que a vanguarda da cena épica estaria indissoluvelmente ligada, e não especialistas teatrais.

A reflexão de Brecht é fundamental porque historiciza a forma épica de seu teatro. Para um coletivo teatral que pretenda produzir no Brasil contemporâneo, esta historicização do teatro épico é parte material do trabalho, tanto quanto a sala de ensaio ou os exercícios físicos praticados pelos atores. Em um país em que a noção de indivíduo se forma dissolvendo-se, a tradição dramática, fundamental à superação proposta pelo teatro épico, é frágil. De fato, a questão colocada diante dos dramaturgos brasileiros dos séculos XIX e XX sempre foi: como compor um drama, forma cuja estrutura erige-se sobre a autonomia do indivíduo burguês, em um país em que o trabalho assalariado, essência do modo de produção capitalista, convive com o trabalho escravo e/ou precarizado? Para os dramaturgos da segunda metade do século XX, principalmente a partir da experiência do Teatro de Arena, a questão aprofundou-se:

\footnotetext{
${ }^{129}$ BAUDELAIRE, Charles. Obra completa. Rio de Janeiro: Aguilar, 1997, p. 354.
} 
como fazer teatro épico em um país que é e não é capitalista?

Durante o processo de criação de Miopia, é possível perceber, pelos registros dos ensaios e das versões de roteiro criadas sucessivamente, um afastamento da forma épica tradicional. Tal afastamento agônico gerou uma forma de caráter labiríntico que não pode ser chamada de teatro épico e nem sequer pensada a partir de uma aproximação ao que Hans-Thies Lehmann convencionou chamar de "teatro pós-dramático".

A conceituação criada por Lehmann será melhor discutida no transcorrer deste trabalho. Mas não podemos utilizá-la para aproximar-nos de Miopia basicamente por duas razões: primeiro porque o que Lehmann chama de pós-dramático insere-se em uma categoria bastante genérica e imprecisa, baseada em uma reflexão que não leva em conta a relação entre procedimentos formais e tempo histórico: Lehmann não consegue definir traços característicos do que seria o teatro pós-dramático, para além de uma negação dos pressupostos comuns ao drama: narrativa, conflito e diálogo. Tais pressupostos são comuns a inúmeras formas teatrais ao longo da história como a tragédia grega, o teatro elisabetano e mesmo o teatro épico ou o das vanguardas europeias: assim, dizer que o teatro pós-dramático é aquele que veio depois do drama não significa dizer muito, já que um conceito tão ampliado de drama é incapaz de explicitar o processo histórico de surgimento do que seria uma nova forma teatral, capaz de suspender pressupostos anteriores. Em segundo lugar, é impossível não considerar, na reflexão crítica sobre Miopia, as particularidades da realidade histórica brasileira, bastante distante da alemã, presente na teorização de Lehmann.

Prefiro utilizar o conceito de forma labirinto para caracterizar Miopia. Tal forma reflete as incertezas do processo de criação, em um momento histórico de crise do capitalismo, e revela também aspectos presentes no resultado da peça.

Comecemos com a pequena cena inicial, para tentarmos avançar nesta reflexão:

CENA 1 - A HISTÓRIA SEM HISTÓRIA

Rosa Medeiros. Presa numa teia, divide o fio narrativo com o público. É incapaz de contar, de articular uma narrativa.

ROSA - Mijei e caguei outra imagem no meu berço nunca tão limpo desde

sempre e memórias eu as digo como ouço murmuro-as na lama

memórias Rosas meu nome Rosa Medeiros memória comprimida em fracassos murmúrios na lama

em mim as histórias fogem sobras de uma voz antiga em mim não minha

minha vida último estado última versão mal dita mal ouvida mal recapturada 


na lama perdas por toda parte
outra imagem
tão depressa outra vez as imagens vêm e vão parte um
elas cessarão
$\begin{aligned} & \text { as imagens parte um } \\ & \text { eu as vejo na lama uma luz se acende elas cessarão as imagens }\end{aligned}$
eu só quero murmúrios
gritar a história despedaçada que agora muda vou contar
sem conseguir ver as pupilas perfuradas pela história que muda
não posso mudar ${ }^{130}$

A primeira característica que literalmente salta aos olhos na leitura do texto desta cena é a disposição espacial das palavras no papel. Tal disposição procura reproduzir o tatear, o tartamudear da narradora. A cena foi criada a partir de uma improvisação em que a atriz que viria a representar Rosa Medeiros propôs uma narradora muda. Tal narradora, carregando uma mala vazia, teria como função conduzir o público pelo espaço em que as cenas transcorreriam. Esta condução, no entanto, deveria gerar um embaralhamento, deveria desorientar o público no seu andar pelo espaço cênico. A desorientação proposta foi tamanha que, em uma versão posterior para a improvisação, que percorria os becos e corredores estreitos e escuros da Usina, a atriz representou acompanhada de um novelo de linha, que era amarrado em objetos de cada espaço percorrido, para que o público não se perdesse no caminho entre as cenas. Nesta que foi uma das primeiras improvisações propostas, já estavam contidos aspectos fundamentais do processo de criação e da forma definitiva da peça: a tentativa nula de se estabelecer uma narrativa e a imagem do labirinto. Posteriormente, quando fui escrever o texto, propus não uma narradora muda mas uma personagem que tenta, sem sucesso, articular uma narrativa. A forma espacial das palavras presente no texto foi utilizada pela atriz para criar suas partituras físicas e vocais, ambas construídas sobre lacunas, tremores físicos e, no dizer das palavras, gritos, espasmos, gagueiras e silêncios.

Presente na rubrica e na encenação está a imagem da teia. A teia tinha 6 metros de extensão e 12 metros de altura e estava fixada nas paredes do espaço cênico. $\mathrm{O}$ espaço era uma enorme vala de descarte do lixo, primeira máquina utilizada na compostagem dos detritos que chegavam à usina. O público posicionava-se bastante próximo da vala, quase imerso na teia. A encenação propunha logo no início da peça o embaralhamento entre personagens e público, situando-os ambos como parte do lixo, seguindo o mesmo

${ }^{130}$ ALMEIDA, Ligia Marina; DELMANTO, Ivan; FARIA, Fernanda, et al. Miopia. Inédito, 2006, p. 1. 
trajeto percorrido pelo lixo na Usina. A teia foi confeccionada com grandes fitas de isolamento, pretas e amarelas, as mesmas utilizadas nas cidades para isolar ruas e áreas interditadas ou acidentadas. A utilização de signos da linguagem urbana, presentes nos tecidos das cidades contemporâneas, seguiu o critério da confecção de ruínas: foram utilizados em toda a peça, e esta primeira cena exemplifica bem este aspecto, objetos capazes de construir uma paisagem de ruínas, alegoria da cidade utópica construída na peça e das cidades capitalistas em geral, fraturadas por ilhas de desenvolvimento assoladas por periferias de deterioração. Ao contrário das regras geralmente presentes nos espetáculos teatrais profissionais, o parâmetro de utilização destes objetos não foi o do "bem acabado", da mercadoria "limpa e nova e abençoada pelo valor de troca " mas sim o da degradação, da corrosão do valor de troca. A teia, e quase todos os objetos cênicos empregados subsequentemente no espetáculo, não eram mercadorias utilizáveis: partiram todos do descartado, do sem valor, do gasto e do encardido, constituindo uma coleção de ruínas.

\begin{abstract}
O que jaz em ruínas, o fragmento altamente significativo, a ruína: é esta a mais nobre matéria da criação barroca. O que é comum às obras deste período é acumular incessantemente fragmentos, sem um objeto preciso, e, na expectativa de um milagre, tomar os estereótipos por uma potenciação da criatividade. (...) $\mathrm{O}$ que a Antiguidade lhes legou são os elementos com os quais, um a um, amassam a nova totalidade. Melhor: a constroem. Pois a visão acabada desse novo era a ruína. O que essa técnica, que em termos de pormenor se orientava ostensivamente pelas coisas concretas, pelas flores de retórica, pelas regras, procurava era o domínio exuberante dos elementos antigos numa construção que, sem conseguir articulá-los num todo, fosse ainda assim, mesmo na destruição, superior às harmonias das antigas. (...) A imagem do homem genial (...) é a de um homem capaz de manipular soberanamente modelos" $" 131$
\end{abstract}

Esse processo de suspensão dialético, capaz de destruir os elementos antigos em uma nova construção, pode ser visto inicialmente na construção do texto da narradora. O texto foi construído a partir da pilhagem e destruição de um fragmento de Beckett, presente no romance Como é. Vejamos o ponto de partida, um fragmento de Beckett: como era eu cito antes de Pim com Pim depois de Pim como é três partes eu o digo como ouço (...)

momentos passados velhos sonhos de volta outra vez ou novos como os que passam ou coisas coisas sempre e memórias eu as digo como ouço murmuro-as na lama (...)

${ }^{131}$ BENJAMIN, Walter. Origem do drama trágico alemão. Lisboa: Assírio \& Alvim, 2004, p. 193-194. 
minha vida último estado última versão mal-dita mal-ouvida mal-recapturada mal-murmurada na lama breves movimentos da face inferior perdas por toda parte ${ }^{132}$

O fragmento de Beckett foi trazido por mim e experimentado no seguinte dia de ensaio:

11/10/2005: Tentativa de romper com as glossolalias. Trouxe fragmento de Beckett para substituir a narradora muda por alguém que tenta mas não consegue narrar. Aquecimento com a teia. 1 hora Elenira enrola-se e desenrola-se, experimenta ações com a teia. Exaustão. Experimentação com o texto de Beckett. Entrego o texto impresso em um papel gasto. Elenira fura o papel com uma chave de fenda. O amassa e o rasga. Queima-o com o isqueiro. Ela repete o texto várias vezes, mas acrescenta algumas palavras: "imagem". "Eu". "Rosa Medeiros". Incorporar estas palavras à próxima versão do texto. ${ }^{133}$

O mesmo ensaio foi descrito assim pela atriz:

Lembrei-me durante o ensaio da minha proposta anterior para a cena, a partir dos textos, das glossolalias e dos desenhos de Artaud. Busquei no exercício os mesmos princípios que estudamos em Artaud e na sua "cena subjétil": a travessia, o ato de atravessar o suporte inerte da representação, o através, o abrir para si uma passagem, o entre, a força de percussão e de projeção, o trabalho oblíquo que consiste em minar, perfurar e limar a folha, a letra, o muro, a parede de ferro invisível. Em busca de um Artaud dialético. ${ }^{134}$

A glossolalia, termo que aparece nos dois relatos de ensaio, designa, a grosso modo, o dom sobrenatural de falar línguas desconhecidas. O termo subjétil, mencionado por Elenira, é uma noção clássica da pintura, que pertence ao jargão da Renascença italiana. Designa o suporte, a superfície, o material, o corpo único da obra em seu primeiro acontecimento, no nascimento ${ }^{135}$. Enquanto suporte, material, receptáculo da obra, o subjétil é, segundo as artes, o papel, a tela, a madeira, o mármore etc. As estranhas cartas que Artaud envia a diversos correspondentes em 1937 e 1939 e que ele atribui o nome de sortilégios (sorts) são um exemplo emblemático desta vontade de

${ }^{132}$ BECKETT, Samuel. Como é. São Paulo: Iluminuras, 2003, p. 11.

${ }_{134}^{133}$ DELMANTO, Ivan. Caderno de direção- 2005. Inédito, 2005, p. 98.

${ }^{134}$ PEIXOTO, Elenira. Em busca de uma interpretação dialética. In: ALMEIDA, Ligia Marina; FARIA, Fernanda; DELMANTO, Ivan, et al. Anjos do desespero. Relatório da terceira etapa de pesquisa. Apresentado à Secretaria de Cultura do Município de São Paulo, 2006, p.22. Inédito. Disponível para consulta na Divisão de Fomento da Secretaria Municipal de Cultura.

${ }^{135}$ DERRIDA, Jacques. Enlouquecer o Subjétil, São Paulo: Editora Unesp, 1998, p. 29. 
“enlouquecer o subjétil” da qual fala Derrida. Missivas perfuradas e queimadas, são um instrumento de revolta, no qual a prática do desenho faz corpo com a prática da escritura. Escritos e desenhados, eles conjugam a potência imprecatória das palavras, a força visual dos signos gráficos e a experiência do fogo voluntariamente aplicado ao papel. Violentamente coloridos, perfurados, queimados, maculados e maltratados, eles são uma operação mágica e cirúrgica, "uma máquina que tem sopro", um projétil que transgride um limite, que maltrata a pele das palavras, que deforma a língua, que desfigura a sintaxe, que age por perfuração, que atravessa a folha, a letra, o muro - e passa para o outro lado. O objetivo de tal operação? "Um exorcismo da maldição, uma vituperação corporal contra as obrigações da forma espacial, da perspectiva, da medida, do equilíbrio, da dimensão", escreve Artaud. A força de dilaceramento que atravessa tais cartas não é somente gráfica. Deve ser também entendida como trajetos sonoros, bombardeios, entonações, gritos, que causam por sua vez um impacto, um choque violento, algo como uma perfuração no olhar. Que se trate dos sortilégios, dos “desenhos escritos", dos retratos e autorretratos e das centenas de páginas dos cadernos de Rodez e de Ivry, asilos em que Artaud permaneceu internado, o movimento que os atravessa é sempre da mesma ordem: desenhar para Artaud não significa apenas representar por traços alguma coisa, é também submeter a língua à uma espécie de terremoto, de torção, de loucura. É forçar a gramática da palavra, destruir a autoridade da linguagem articulada, combater a língua a partir dela mesma. Nesse sentido, o "subjétil" é também a língua francesa. E Artaud faz com ela o que ele faz com o "subjétil": ataca-a, opera-a, maltrata-a em todos os sentidos. O objetivo do Artaud poeta é fazer a língua francesa entrar em crise, delirar. Essa prática do enlouquecimento da língua vai atingir seu grau máximo de intensidade, de vibração e de dissonância, com estes "vocábulos corporais", estas "sílabas inventadas", que são as glossolalias de Antonin Artaud. Transbordando a lógica da língua-carcaça, da língua-código, elas pulverizam o valor representativo da linguagem e são, como são também todos os seus desenhos retratos, palco do Teatro da Crueldade. É esta relação entre a problemática do desenho (perfurar o suporte, desfigurar o rosto humano) e a problemática da língua (enlouquecer a língua) que constituiu o foco das primeiras improvisações apresentadas por Elenira a partir da proposta da narradora muda. A narradora gravava no próprio corpo, cortando-se, as palavras que não conseguia expressar. Este corpo que Artaud chamou de "infinitamente potencial, com poder de explodir, em luta contra a arte, a organização do organismo, a representação, a língua-carcaça e deus". Corpo com o 
poder de fazer "dançar a anatomia humana" que é também o poder de refazer o corpo:

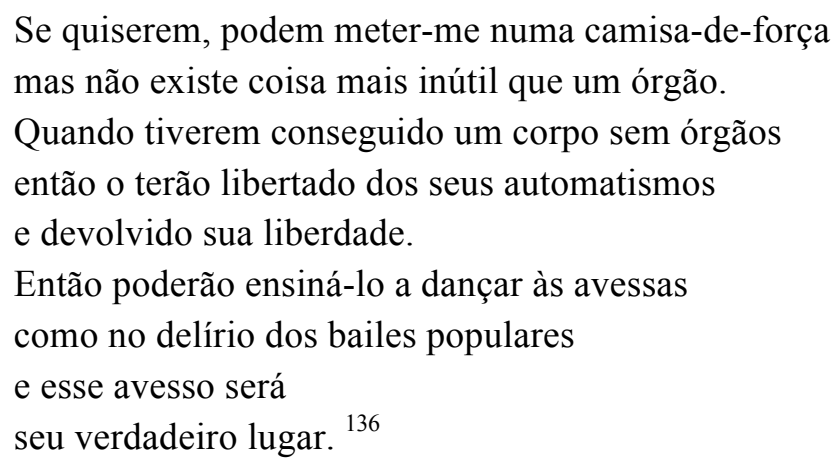

Quando trouxe pela primeira vez a proposta da narradora muda, Elenira apresentou-nos também este poema de Artaud, Para acabar de vez com o juízo de deus, como uma contextualização à cena apresentada. Esta busca por "um Artaud dialético", mencionada em seu relatório, chegou a constituir-se como horizonte de experimentação que envolveu o desenvolvimento da personagem/narradora e já na segunda versão de improvisação as palavras riscadas no corpo de Rosa eram glossolalias retiradas dos escritos de Artaud:

\begin{tabular}{|c|c|c|}
\hline ROSA - & kré & puc te \\
\hline & kré & puk te \\
\hline & pek & li le \\
\hline & kre & pek ti le \\
\hline & $\mathrm{e}$ & kruk \\
\hline & pte & kruk $^{137}$ \\
\hline
\end{tabular}

A disposição desenhada das palavras, com o branco da página ganhando significação a ser explorado na encenação, já surgia nesta primeira versão de texto. As glossolalias não eram pronunciadas pela atriz, mas eram escritas no seu corpo com tinta, durante o transcorrer da cena. Na medida em que novas improvisações eram realizadas, o corpo da narradora foi sendo utilizado como suporte, subjétil, para várias formas de fixar as glossolalias: papéis que eram colados nos braços e nas pernas, canetas coloridas, placas de papelão. No entanto, a cena parecia apresentar apenas um dilaceramento, como resultado imutável e atemporal, e não o processo de esgotamento

\footnotetext{
${ }^{136}$ ARTAUD, Antonin. Works from the final period. Boston: Exact Change, 1995, p. 285.

${ }^{137}$ DELMANTO, Ivan. Miopia. Primeira versão de dramaturgia. In: ALMEIDA, Ligia Marina; FARIA, Fernanda; DELMANTO, Ivan, et al. Anjos do desespero. Relatório da primeira etapa de pesquisa. Apresentado à Secretaria de Cultura do Município de São Paulo, 2005, p. 154. Inédito. Disponível para consulta na Divisão de Fomento da Secretaria Municipal de Cultura.
} 
da narrativa, que parecia ao grupo - que naquele momento lia e discutia $O$ Narrador de Walter Benjamin - mais adequado à investigação sobre a atualidade do teatro épico. $\mathrm{O}$ texto de Beckett foi proposto no lugar das glossolalias como mote de improvisação em uma tentativa de formalizar tal emudecimento da narrativa, já que:

A narrativa é para ele um exercício de memória. (...) Mas (...) Molloy não tem esperanças de que a somatória deste acúmulo de fatos redunde em um sentido unitário, resgate uma identidade perdida, enfim, faça de sua vida uma totalidade significativa. A memória é fonte de dor e desconcerto, demonstração da arbitrariedade do destino e da ação predatória do tempo. (...) A arte não traz à tona um sentido oculto, não desentranha uma continuidade que o presente esconde, mas deixa evidente o desencontro perpétuo do sujeito consigo mesmo, vítima da mobilidade do desejo e das configurações caleidoscópicas de sua própria subjetividade, do outro com que se relaciona, das coisas do mundo. ${ }^{138}$

Naquele momento, a experimentação com o fragmento de Beckett, que passou a ser lido em cena pela atriz que depois perfurava e amassava o suporte do texto - ora uma folha, ora um pedaço de papelão, ora uma garrafa de plástico - contribuiu para a construção de uma personagem que se afastou dos paradigmas de Stanislavski, Meyerhold, Brecht e Artaud, que vinham sendo estudados até aquele momento, na busca por uma narradora que pudesse expressar aquele "desencontro perpétuo do sujeito consigo mesmo, vítima da mobilidade do desejo e das configurações caleidoscópicas de sua própria subjetividade", de que nos fala Fabio de Souza Andrade. Parecia-nos que a personagem de Rosa não poderia ser representada como um indivíduo e o texto de Beckett poderia nos conduzir a um resultado semelhante ao que Adorno identificou nos seres de Fim de partida:

As catástrofes que inspiram Fim de partida têm feito saltar pelos ares aquele indivíduo cuja substancialidade e condição absoluta constituía o que de comum tinham Kierkegaard, Jaspers e a versão sartreana do existencialismo. (...) $\mathrm{O}$ indivíduo mesmo, enquanto categoria histórica, resultado do processo capitalista de alienação (...), se tem feito uma vez mais como algo efêmero. (...) A dramaturgia de Beckett o abandona como a um bunker antiquado. ${ }^{139}$

Este abandono do indivíduo foi tentado em uma série de exercícios que buscavam a atuação de Elenira não mais baseada no superobjetivo e nos objetivos sistematizados

\footnotetext{
${ }^{138}$ ANDRADE, Fabio de Souza. Samuel Beckett: o silêncio possivel. Cotia: Ateliê Editorial, 2001, p. 49.

${ }^{139}$ Idem, p. 279.
} 
por Stanislavski; ou mesmo na dialética entre identificação e distanciamento do personagem, presente no trabalho do ator de Brecht; mas sim baseada em uma narradora incapaz de organizar em sua subjetividade a miríade de vozes contraditórias que a constituíam:

12/10/2005: Construir a personagem não a partir da ideia de objetivo mas a partir de uma realização de desejos. Desejos incontroláveis, que surgem e desaparecem repentinamente, em contradição. A partitura de ação de Rosa ficou assim: 1. desenrolarse da teia./ rasgar a teia. 2. Riscar o corpo/ rasgar a roupa/ andar para a frente e para trás/ rasgar a teia/ prender-se novamente na teia. 3. Começa o texto para o público/ para de dizer o texto/ engasga com a teia/ acende a tocha/ apaga a tocha. ${ }^{140}$

Aos poucos, com o suceder dos ensaios, o fragmento de Beckett foi sendo reescrito durante as seguidas improvisações. As mudanças em relação ao texto de Beckett indicam aspectos importantes da versão final de Miopia. O nome da narradora, Rosa Medeiros, que se repete sem que consiga trazer à superfície as memórias da personagem, indicam o emudecimento e a dificuldade da articulação da experiência e da própria personalidade. Mais do que isso, tentam responder a uma das grandes questões presentes em todo o processo de criação de Miopia, indagação que também estrutura o conceito de teatro pós-dramático: é possível narrar em tempos de ultramodernidade? Rosa Medeiros não consegue. Essa personagem tenta também, a todo custo, constituirse como indivíduo, sem conseguir.

Uma das vozes que constituem a narradora, que "fala de uma consciência ocupada por outras, coro dos contrários, um arremedo de eu em que uma voz decisiva, sempre outra, de outra, ora toma o poder de assalto, ora é consensualmente eleita, como um síndico de um condomínio de vozes" ${ }^{\text {,141 }}$, pode ser vista com a identificação de mais uma mudança em relação ao fragmento do autor irlandês: a obsessão pelas "imagens que vem e vão". O tema da imagem aparece ainda no mencionado "cinema" e nas "pupilas perfuradas pela história”. No entanto, essa busca por uma construção transparente do sentido, na cena primeira de Miopia, reduz a potência enigmática e aberta do texto de Beckett que, segundo Adorno:

Não suprime o temporal na existência, a qual sem dúvida só seria tal temporalmente, senão que extrai dela o que o tempo - a tendência histórica - está realmente a ponto de carregar-se. Alarga a via de escape da liquidação do sujeito até o ponto em que este se

\footnotetext{
${ }^{140}$ DELMANTO, Ivan. Caderno de direção- 2005. Inédito, 2005, p. 99.

${ }^{141}$ ANDRADE, Fabio de Souza. Samuel Beckett:o silêncio possível.Cotia: Ateliê Editorial,2005, p. 157.
} 
contrai em um aqui e agora cujo caráter abstrato, a perda de toda qualidade, reduz literalmente a ontologia ad absurdum, àquele absurdo em que se transmuta a mera existência enquanto é absorvida em sua nula igualdade consigo mesma. ${ }^{142}$

A polifonia expressa na fala de Rosa, ao invés de abandonada à "nula igualdade consigo mesma de uma existência absurda", presente no fragmento de Beckett, tem seus múltiplos sentidos vetorizados, domesticados, pela presença reiterada deste tema da "imagem". Os farrapos de discurso passam a direcionar, a indicar um sentido único, e tal sentido aponta para um dos grandes temas do restante da peça: o mundo como espetáculo. Para Guy Debord, a sociedade do espetáculo seria caracterizada por:

As imagens que se desligaram de cada aspecto da vida fundem-se num curso comum, onde a unidade desta vida já não pode ser restabelecida. A realidade considerada parcialmente desdobra-se na sua própria unidade geral enquanto pseudo mundo à parte, objeto de exclusiva contemplação. (...) O espetáculo não é um conjunto de imagens, mas uma relação social entre pessoas, mediatizada por imagens. (...) $\mathrm{O}$ mundo ao mesmo tempo presente e ausente que o espetáculo faz ver é o mundo da mercadoria dominando tudo o que é vivido. (...) O espetáculo é o capital a um tal grau de acumulação que se torna imagem. ${ }^{143}$

Este aspecto de relação social entre pessoas, mediatizada por imagens, não aparece nesta primeira cena de Miopia: o que vemos aqui é apenas este conjunto de imagens, mencionado no texto mas sem paralelo na encenação. Assim, parece que a prisão em que jaz a narradora, a teia da memória que ela própria é incapaz de tecer, e a repetição de um texto que reitera a presença esmagadora do mundo das imagens, tem uma relação de causa e efeito: "força da consciência para pensar a história, a força da memória, se tem esgotado. O drama se converte em gesto mudo, congelado em meio ao diálogo. Da história meramente aparece todavia seu resultado como sedimento." $" 144$

Força da memória esgotada, o sedimento da história, que parece depositar-se sobre Rosa Medeiros como a enorme teia de fita de isolamento, é alegorizado por esta repetição circular da temática da imagem em que, ao contrário do que se dá no fragmento de Beckett, este universo histórico que está separado e oposto à narradora é nomeado: "As palavras falham, o diálogo não se cumpre, a luz da razão não esclarece a própria identidade.(...) A voz que Molloy não sabe precisar de onde vem, se do fundo

\footnotetext{
${ }^{142}$ ADORNO, Theodor. Notas sobre literatura. Madrid: Akal, 2003, p. 276.

${ }^{143}$ DEBORD, Guy. A sociedade do espetáculo. Rio de Janeiro, 1997, p. 13-35.

${ }^{144}$ ADORNO, Theodor. Notas sobre literatura. Madrid: Akal, 2003, p. 276.
} 
de si próprio ou de alguém ou algo indefinido, dele separado ",145

Apesar de estilhaçada, não há indefinição na fala de Rosa. As palavras, ao falharem, expressam a realidade precisa da circulação do capital tornado imagem. Talvez porque as sucessivas experimentações com o texto de Beckett tenham levado a cena a constituir-se como paródia do escritor irlandês. Procedimento este que não era estranho ao autor de Fim de partida:

As categorias dramáticas são em sua totalidade tratadas como o humor. Se parodiam todas. Mas não se tornam objeto de burla. Enfaticamente, paródia significa a utilização de formas na época de sua impossibilidade. Demonstra essa impossibilidade e com isso modifica as formas. As três unidades aristotélicas se conservam, mas o drama perde a vida. (...) Os componentes dramáticos aparecem depois da morte destes. Exposição, conflito, ação, peripécia e catástrofe voltam para uma autópsia dramatúrgica como decompostos. ${ }^{146}$

Se Adorno identifica em Fim de partida a utilização dos procedimentos dramáticos como paródia, é possível observar na primeira cena de Miopia esta utilização da forma do fragmento de Como é "na época de sua impossibilidade":

Na obra final, esta anatomia da identidade concentrada nos
processos metabólicos essenciais, da vida resumida a pulso e
respiração, vai se acentuar, assim como a atenção máxima aos
órgãos responsáveis por dois dos processos perceptivos essenciais:
os olhos e os ouvidos. Os primeiros, objetivados pelas lágrimas,
são incapazes de se diferenciar daquilo que veem: "eu sou o ar, as
paredes, o emparedado, tudo cede, se abre, deriva, reflui, flocos,
sou todos esses flocos". De forma análoga, os ouvidos trazem
vozes que são portadoras de memórias equívocas, possível e
mesmo provavelmente manifestações exteriorizadas de lembranças
que dizem respeito ao ouvinte. ${ }^{147}$

A caracterização de uma vida resumida a pulso e respiração, aos processos perceptivos essenciais dos olhos e dos ouvidos, parece corresponder a uma cena em que a personagem surge coberta e presa a uma teia, proferindo palavras que demonstram sua obsessão por realizar estes processos primários, esmagada e impedida por memórias que vêm e vão, em forma de imagens. No entanto, a modificação empreendida pelos criadores de Miopia no combate com o texto de Beckett, pode revelar uma certa desconfiança com a forma do fragmento escolhido como estímulo inicial: como se a emergência definitiva da sociedade do espetáculo condenasse aquela forma à

\footnotetext{
${ }^{145}$ ANDRADE, Fabio de Souza. Samuel Beckett:o silêncio possível.Cotia: Ateliê Editorial, 2005, p.4749.

${ }^{146}$ ADORNO, Theodor. Notas sobre literatura. Madrid: Akal, 2003, p. 292.

${ }^{147}$ Idem, p. 153.
} 
impossibilidade. Nesta tentativa de adaptar o fragmento de Beckett para torná-lo "apto" a tratar desta sociedade mediada por imagens, a primeira cena de Miopia reduz em potencial de abertura e domestica a linguagem rarefeita do texto de Como é sem conseguir plasmar tal sociedade. O conteúdo da cena é abstrato porque baseado em palavras soltas e esvaziadas de sentido, de tão repetidas, como a palavra "imagem". A ação apresentada remete à mudez da narradora e às suas causas, esta hipertrofia da imagem, sendo incapaz, entretanto, de revelar as mediações históricas que denotam tal emudecimento.

Esta obsessão pelas imagens, que perfuraram as pupilas da narradora, percorre Miopia por inteiro. E o grupo parecia ter consciência da época de impossibilidade em que vivia, já que inúmeras formas aparecem testadas durante toda a peça, até o seu final, em busca destas relações sociais espetaculares. O mundo do espetáculo, que no fracasso narrativo de Rosa aparece apenas como imagens a povoarem o espaço, como nuvens de insetos a perfurarem o olhar, só se revelaria como verdadeiro modo de produção na cena final da peça:

CORO DOS SEM-TETO - Vamos invadir o cinema!

Vamos morar neste palácio das formas, das imagens e dos valores Frágeis

Até que nos vomitem

Um teto sólido, de uma caverna oca, para morar.

Até que o mundo corroído lá de fora

Desabe.

Nós não habitamos colmeia. Não moramos em lugar nenhum.

A nossa colmeia é lavada no sangue

dos que têm abrigo, comida e dinheiro para ser o que não somos.

MÉRCIA - O cinema agora é nosso! (Gritos) E não vamos sair daqui enquanto não nos derem onde morar! São 42 famílias desabrigadas que agora vão morar aqui! E só vamos sair se for para o cemitério! (Gritos) Ninguém sai daqui vivo! Não vamos sair daqui!

FAUSTO - (Com um megafone, lá fora) Por favor, cidadãos, os senhores estão sendo filmados. Saiam ou o poder público terá que invadir. Este cinema foi desativado porque construiremos aqui um shopping center: um edifício infinito, com corredores do tamanho do universo, formando um labirinto eterno, para todas as pessoas do Brasil e do mundo. Um shopping center voltado para vocês, cidadãos consumidores. A prefeitura vai implodir o prédio dentro de quinze minutos. Por favor, retirem-se. O prefeito Belmiro está aqui ao meu lado e promete que não haverá violência. Vamos começar a contagem regressiva. (Soa um alarme)

BELMIRO - Formem uma fila. Retirem suas roupas. Não queremos ninguém armado. Caminhem bem devagar. Em silêncio. 
CORO DOS SEM-TETO - (Enquanto se retiram do cinema) Vamos invadir o cinema!

BELMIRO - Em silêncio eu disse! Em silêncio! Em silêncio!

CORO DOS SEM-TETO - Vamos morar neste palácio das formas, das imagens e dos valores

Frágeis

Até que nos vomitem

Um teto sólido, de uma caverna oca, para morar.

Até que o mundo corroído lá de fora

Desabe.

Nós não habitamos colmeia. Não moramos em lugar nenhum.

A nossa colmeia é lavada no sangue

dos que têm abrigo, comida e dinheiro para ser o que não somos.

MÉRCIA - Frouxos! Covardes! Eu não saio! Eu não vou sair!

MARIBEL (Com um megafone, lá fora) - Mãe, sou eu.

Sai daí, por favor. Não vale a pena. O futuro chegou e quer entrar.

Eles vão demolir o cinema. Saia daí, mãe. Por favor. Não vale a pena.

A demolição começa. Mércia é enterrada viva.

MÉRCIA - EU NÃO QUERO MAIS CONTAR

Eu abandono tudo. Então eu nego. Eu nego a história dos que pisam o chão cheio de vítimas. Eu estou do lado dos soterrados. E até que tenhamos uma história de futuro para contar, eu estou aqui, sob o chão, ao lado das vítimas, negando tudo o que existe como é. Que venha então o pesadelo. Nós o olhamos debaixo. Que venha o pesadelo. Porque do pesadelo pode-se acordar.

nenhuma resposta terminar nenhuma resposta posso me engasgar nenhuma resposta afundar nenhuma resposta não mais conspurcar a lama nenhuma resposta o escuro nenhuma resposta não mais perturbar a paz nenhuma resposta o silêncio nenhuma resposta morrer nenhuma resposta

MARIBEL - Mãe! Nenhuma resposta. Mãe! Nenhuma resposta. Nenhuma resposta Esse é o fim é como é como não pode ser é o fim como é ${ }^{148}$

A repetição do texto de Beckett, na primeira e na última fala da peça parece indicar nova tentativa de paródia. O fragmento do Como é que serviu de estímulo à construção da última cena de Miopia foi este:

nenhuma resposta terminar nenhuma resposta posso me engasgar nenhuma resposta afundar nenhuma resposta não mais conspurcar a lama nenhuma resposta o escuro nenhuma resposta não mais perturbar a paz nenhuma resposta o silêncio nenhuma resposta morrer nenhuma resposta MORRER gritos EU POSSO MORRER gritos EU VOU MORRER gritos bom

bom bom fim afinal da parte três e última eis como era fim da

${ }^{148}$ ALMEIDA, Ligia Marina; DELMANTO, Ivan; FARIA, Fernanda, et al. Miopia. Inédito, 2006, p. 41. 
citação depois de Pim como é 149

Se para Adorno, na paródia do drama realizada por Beckett em Fim de partida "os componentes dramáticos aparecem depois da morte destes" e "exposição, conflito, ação, peripécia e catástrofe voltam para uma autópsia dramatúrgica como decompostos", a autópsia de Beckett realizada na última cena de Miopia não está presente no texto da peça, já que esta reproduz quase que na íntegra o fragmento extraído de Como é, mas sua decomposição é empreendida pela encenação. Se é possível dizer que nos romances de Beckett:

Nestas personagens é notável o esfumamento das separações entre
o delírio interior, manifestando-se sob a forma de vozes que
estilhaçam a identidade dos sujeitos, e a realidade exterior, sempre
avaliada como ameaçadora e medíocre. (...) É a própria
epistemologia que está em jogo, as possibilidades de que sujeito e
objeto, polos do processo de conhecimento, se mantenham
determináveis. (...) Este nivelamento dos fatos, equivalência
forçada, impossibilita que o romance apresente um
desenvolvimento, no sentido tradicional do termo, seja dramático,
do enredo (um progressivo aumento de tensão), seja psicológico, da
personagem (amadurecimento e incorporação das experiências à
identidade individual). Molloy não aprende, nem se modifica, a não
ser pelo processo de decadência física a que se encontra
submetido.

É possível ver também em Miopia esta ausência de modificação na trajetória dos personagens e no percurso da própria peça como um todo. Não há enredo e progressão dramática: a primeira cena, narrada por Rosa, e a última cena, em que o cinema é destruído, completam-se em circularidade. A utilização de fragmentos do Como é nas duas cenas revela este pêndulo da má infinitude: apesar da fábula recheada de episódios, apesar da transformação espacial narrada em Miopia, a saga de nascimento e derrocada da cidade utópica é, no fundo, narrativa estagnada, ou o cadáver exposto do próprio ato de narrar. Desde o início da peça, o que se conta, sob inúmeros disfarces, em cenas de aparências distintas, é a permanência de uma realidade esvaziada de sentido, em que as imagens parecem circular infinitamente, sem modificação. O programa de Miopia apresentava em suas primeiras páginas a fábula integral da peça porque no fundo os criadores percebiam que a apresentação não era suficiente para revelar qualquer movimento narrativo.

\footnotetext{
${ }^{149}$ BECKETT, Samuel. Como é. São Paulo: Iluminuras, 2003, p. 164.

${ }^{150}$ ANDRADE, Fabio de Souza. Samuel Beckett: o silêncio possivel. Cotia: Ateliê Editorial,2005 p. 5053.
} 
Não obstante, a forma utilizada por Beckett em Como é só pode ser incorporada à peça sob o disfarce da paródia porque esta estagnação narrativa é desenvolvida em Miopia ainda sob a cisão determinada entre sujeito e objeto: definem-se narradores responsáveis por contar a história; definem-se cenas que representam o que está sendo contado; define-se a história de transformação de um espaço. Assim, o que em Beckett era dissolução (fronteira entre realidade exterior e delírio interior), surge decomposto, fora de lugar, em Miopia: na verdade, surge deslocado porque há na peça o procedimento de paródia de duas formas simultâneas e distintas. A combinação dos procedimentos épicos (a narração de uma história) com a exposição de uma história que não se move seria capaz de promover a realização de uma autópsia da narrativa, o que parece nos indicar a convivência híbrida entre formas cercadas por suas impossibilidades.

É como se o encontro com o texto de Beckett, não por acaso inserido no início e no final da peça, traçando um círculo de paralisia, fosse tão significativo quanto todo o processo de investigação sobre a dialética no teatro, e sobre a herança do teatro épico em geral, realizado pela II Trupe de Choque naqueles anos. O que as inúmeras e exaustivas versões de improvisação realizadas durante a criação da primeira cena da peça revelam é que já naquele momento, início do processo de criação, o grupo percebia que as formas de narração que perseguiam levariam a peça, paradoxalmente, à mudez. A inserção do texto de Beckett, apesar de irrefletida, revela o que para o grupo naquele momento era ainda inconsciente: a pesquisa fora conduzida até os limites de sua própria negação.

Essa negativa de procedimentos do teatro épico que foram pesquisados durante o processo de criação talvez tenha sido levada ao seu grau máximo na última cena da peça, citada acima. Há um coro de sem-teto que inicia a cena invadindo o antigo cinema de comerciais de Miopia, em busca de abrigo. O diálogo com o momento presente é explícito, já que no ano de apresentação de Miopia, 2006, o Movimento dos Sem-Teto realizara uma série de invasões a cinemas abandonados no centro de São Paulo. Seguindo o texto, percebe-se que a invasão é realizada para que, pouco tempo depois, ameaçados pelas forças de repressão representadas pelo prefeito, os manifestantes retiram-se, silenciosos, do local. O coro dos sem-teto repete exatamente o mesmo texto, durante a invasão e durante sua retirada: esse procedimento parece sugerir, além da fraqueza do movimento social, aquele coro de vozes alheias ao sujeito, integrantes de personalidades em dissolução, a repetirem vozes que não lhes pertencem. 
A encenação deste coro reforça esse panorama de desolação e de paralisia política, de uma ausência de saída generalizada: cada um dos integrantes do coro surgia do lado oposto ao público, na extremidade mais distante do estacionamento da Usina. $\mathrm{O}$ coro surgia fragmentado e estilhaçado: separados uns dos outros, os integrantes caminhavam cada um dentro de um carrinho de plástico, utilizado para recolher o lixo. O público só via os pés dos manifestantes, que por um buraco no fundo do carrinho podiam tocar o chão e conduzir os "homens-lixo" até o cinema. Não havia assim qualquer configuração de um coletivo e, desde o início de sua aparição, este coro já surgia como fracasso político.

Em uma das entrevistas gravadas com o público da peça para o documentário realizado pelo grupo, como parte do projeto de pesquisa, há um depoimento significativo sobre esta cena: "Quando os homens dentro dos carrinhos de lixo saíram eu percebi onde estávamos. Andamos tanto na peça que eu me perdi, me desorientei. Não é que estávamos de volta, no final da peça, ao lugar em que tudo começou?"151

Este retorno ao "lugar onde tudo começou" reafirma a circularidade e estagnação da narrativa, alegorizada pelo percurso percorrido pelas cenas e pelo público no espaço da Usina: tal percurso era também circular, marcado em seu início e seu final pela chegada do ônibus ao estacionamento. O velho ônibus fretado pelo grupo era responsável por levar o público ao início da peça e depois buscá-lo, entregando a todos na estação de metrô Carrão, na zona leste de São Paulo. Ao retornar ao ônibus, durante o trajeto de 30 minutos até o metrô Carrão, o público assistia, em uma pequena TV colocada acima dos bancos, imagens da peça que eram produzidas durante a apresentação do dia. O círculo espetacular se fechara: a presença de uma câmera registrando o público durante a peça sugeria a transformação do mundo, e não só do espaço utópico de Miopia, em imagem posta em circulação. Quando desciam do ônibus, o motorista oferecia a todos um DVD, ao preço simbólico de $\mathrm{R} \$ 1,99$, com as imagens da apresentação e do público da peça gravadas naquele dia. Talvez seja possível perceber, nesta última venda promovida por Miopia, como diria Debord, “o espetáculo como o momento em que a mercadoria ocupou totalmente a vida social. Não apenas a relação com a mercadoria é visível, mas não se consegue ver nada além dela: o mundo que se vê é o seu mundo". Mais ainda: "O consumidor real torna-se consumidor de ilusões. A mercadoria é essa ilusão efetivamente real, e o espetáculo é sua manifestação

${ }^{151}$ ALMEIDA, Thiago. Entrevista concedida ao documentário Miopia. Roteiro e direção de André Moncacio, 2006. 
geral."

A implosão do cinema, visando a construção de um shopping center, foi assim elaborada, segundo relatório de pesquisa escrito logo após a criação de uma das primeiras versões da cena final de Miopia:

Na cena final da peça, há substituição do cinema de imagens por um shopping center. Se a estrutura fundamental da sociedade já foi a fábrica, e o seu exemplo mais emblemático foram as fábricas ligadas à metalurgia (produção de maquinários, automóveis, armas etc.), na sociedade pós-moderna a estrutura essencial da empresa tem o seu melhor modelo no SHOPPING CENTER. O Shopping Center é uma empresa que se utiliza de uma estrutura espacial para confinar seus trabalhadores e consumidores em um espaço concreto (similar ao panóptico, em que qualquer liberdade é vigiada) e, principalmente, em um espaço imaginário: a marca. Um passeio nos labirintos de um shopping é cuidadosamente construído por esta empresa, para que o olhar de cada um, consumidor naquele momento ou consumidor futuro, possa gerar valor à uma infinidade de marcas e de produtos. O shopping center completa a criação de valor iniciada nas empresas produtoras. Se o valor de uma marca é determinado pela profundidade de sua difusão social, o shopping é o espaço em que esta geração se dá de forma concentrada. $\mathrm{O}$ espaço labiríntico do Shopping é construído para eliminar qualquer possibilidade de saída. ${ }^{152}$

A preocupação que regeu a criação desta última cena estava depositada na necessidade de diferenciação: de estabelecer na trajetória de Miopia uma nova etapa de produção de valor, como se em uma linha progressiva do capitalismo o shopping center representasse uma etapa mais avançada em relação ao cinema. Parece que assim o foco da cena deveria se deter na emergência definitiva do trabalho do olhar, alegorizado pelo shopping center, espaço em que tal trabalho ocorreria de maneira perfeita. No entanto, o shopping permanece como esboço: é apenas mencionado na cena e o que vemos é a peça terminar com a imagem da ruína, da implosão e dos restos depositados sobre a cabeça de uma das narradoras, exatamente como na cena inicial de Miopia. Ao contrário do que o meu texto presente no relatório de pesquisa sugeria, a cena final da peça continuou presa a uma visão circular sobre a sociedade do espetáculo, como se este modo de produção de imagens tornadas mercadorias fosse tão absoluto e onipresente que não fosse capaz de sofrer modificações. Mais do que o espetáculo como modo de produção, o que a circularidade de Miopia revela é tal sociedade espetacular como

152 DELMANTO, Ivan. Narrativa em construção. In: ALMEIDA, Ligia Marina; FARIA, Fernanda; DELMANTO, Ivan, et al. Anjos do desespero. Relatório da primeira etapa de pesquisa. Apresentado à Secretaria de Cultura do Município de São Paulo. Inédito, 2005, p.13. Disponível para consulta na Divisão de Fomento da Secretaria Municipal de Cultura. 
modo de destruição permanente, daí o acúmulo de ruínas como imagem presente em toda a peça.

A circularidade também pode ser observada na cena através das falas dos personagens. São falas construídas quase que exclusivamente a partir de chavões e lugares comuns do discurso cotidiano. Tal esfarelamento da linguagem encerra a trajetória de Maribel, Fausto, Belmiro e Mércia, personagens presentes em toda a trajetória da cidade de Miopia e que narraram, cada um em um momento, parte da peça. Assim, se pudemos relacionar as imagens que surgem repetidamente perfurando o olhar da primeira narradora da peça, Rosa, já na primeira cena, ao modo de produção da sociedade do espetáculo, em que o valor se realiza tornando-se imagem e contemplação, talvez caiba nos perguntar quem fala na voz destes narradores fracassados:

Que é o capital que está falando por si só, por cima dos homens e dos instrumentos, não há dúvida. (...) Se ele fala, o que é que está querendo dizer? Penso que não quer dizer nada, ou melhor, nada que não seja sua própria supremacia. (...) Não é por motivos diferentes que shopping centers, hotéis e estados ficam cada vez mais parecidos em suas organizações internas e suas aparências: todos precisam, digamos, falar a mesma língua". ${ }^{153}$

Essa linguagem é mimetizada na explosão dos significantes em videoclipes, telejornais e códigos das operações simultâneas nas bolsas de valores, significantes ruidosos e multicoloridos, eletrocutantes, que empanturram e entorpecem, mas vai além deles. Se Foucault dizia que o sujeito não é a fonte do discurso, mas alguém que articula o discurso prévio ao próprio sujeito, podemos ver nos discursos do coro dos Sem-Teto, de Belmiro, Fausto, Maribel e Mércia aquilo que Eugênio Bucci chama de "discurso do superambiente": algo que pode ser visível na materialidade física do novelo eletrônico e metálico em torno do planeta, que é a própria materialização da linguagem do inconsciente ou, melhor, da ideologia cristalizada. Este discurso prévio ao sujeito é a "própria realidade liquefeita dentro deste superambiente virtual. Se há diálogo entre dois polos quaisquer, o dado novo é que esses polos não mais se encontram do lado de fora do novelo, contemplando as imagens, mas estão incluídos nele ou em sua aura coesa como um campo de força". A realidade, ou o que lhe restou de reminiscências, virou figurante do espetáculo e, para dele fazer parte, vende-lhe a alma e o corpo, como o público de Miopia, que tem suas imagens capturadas por câmeras escondidas sem saber, num processo que torna visível o que antes era apenas fantasmagoria.

${ }^{153}$ BUCCI, Eugênio. Como o capital aprendeu a falar. In: Praga, n. 3, São Paulo: Hucitec, setembro de 1997, p. 118. 


\section{III.2. Dramaturgia da iluminação em Miopia: mímesis soterrada?}

Se a linguagem do capital é mimetizada pelo modo de produção espetacular, que de tão concentrado se torna imagem, pode-se ver na iluminação de Miopia nova mímesis deste processo. Os significantes ruidosos e multicoloridos do espetáculo e de seu novelo eletrônico foram transformados em dramaturgia da luz do espetáculo. À primeira narradora, Rosa Medeiros, sucediam-se outros e mais outros, em uma sucessão de versões em que cada personagem tentava narrar a história da cidade de Miopia à sua maneira. A encenação e a iluminação ganharam assim, de acordo com a voz de cada narrador, materializações diversas, todas ligadas a uma visualidade espetacular.

Talvez seja possível identificar na luz em Miopia uma dramaturgia dialética, capaz de expor contradições. Haveria na iluminação da peça quatro conceitos fundamentais, que perpassariam todo o espetáculo:

1. Contradição: a luz cria imagens que contradizem o que o texto sugere, revelando universos que o discurso escondia.

2. Movimento: há uma transformação contínua de conceitos e de linguagens, a troca de um narrador para o outro estabelece mudanças de concepção e de forma.

3. Totalidade: há a luz do todo, caracterizada pelos focos e fontes de luz que abrangem o ambiente e a situação. E há também a luz da parte, que abrange o personagem e está situada nele, no corpo do personagem e, e não em uma fonte de luz externa: a luz vem do personagem para a cena e da cena para o personagem.

4. Coisificação: Para demonstrar uma realidade em que as coisas tomam o lugar dos homens, há fontes de luz situadas nos objetos, coladas a eles ou dentro deles, criando objetos luminosos (carroça, outdoors, letreiros, vitrines, bonecos etc.), como se tivessem vida. ${ }^{154}$

Assim, teríamos a seguinte dramaturgia da luz, traçada de acordo com as várias vozes dos narradores que contam a peça:

Narração de Rosa, cenas 1 a 5: Rosa é o narrador contemporâneo que não consegue apreender a realidade em todas as suas conexões e determinações. Narra de forma fragmentada, tentando, em desespero, contar a sua própria história, sem conseguir. Rosa narra

154 DELMANTO, Ivan. "Para o conceito da luz". In: ALMEIDA, Ligia Marina; FARIA, Fernanda; DELMANTO, Ivan, et al. Anjos do desespero. Relatório da terceira etapa de pesquisa. Apresentado à Secretaria de Cultura do Município de São Paulo. Inédito, 2006, p. 213. Disponível para consulta na Divisão de Fomento da Secretaria Municipal de Cultura. 
apenas a partir de seu veneno, de seus intestinos, é como a aranha, tecendo a teia de sua própria destruição. Rosa, bem como a história que conta, é vítima de seu próprio caos. Este trecho foi iluminado pelo fogo, principalmente. Até a cena da corrida, Rosa e Belmiro tinham no pescoço uma gargantilha de luz, como se fossem presos pelo que sai de seus discursos. O conceito de encenação parte aqui da ideia do fragmento, de criar universos autônomos, sem relação entre si.

Narração de Mércia, cenas 6 a 14: $O$ narrador Mércia representava o ponto de vista dos excluídos, dos que enxergam a história vista de baixo, soterrados, desfavorecidos. Mércia odeia Miopia e o cinema que ela mesma construiu. Mércia despreza a história que conta. Mércia conta para denunciar, para tentar mudar o mundo revelando as injustiças que o formam. Mércia narra para criar uma história de justiça erguida a partir dos escombros. Trabalhou-se aqui o conceito de iluminação brechtiana, muito clara, que ilumina também o público, buscando revelar contradições. As cenas que Mércia narra foram todas bem iluminadas, utilizando-se para isso de lanternas que a própria personagem distribuía ao público. A concepção deste trecho procurou partir dos preceitos brechtianos, trabalhando com o estranhamento (inclusive na luz) e com o gestus (símbolos que revelam socialmente determinada situação).

Narração de Antenor, cenas 15 a 20: Antenor narra para entreter Dilce, buscando adiar o instante de sua morte. Ele é como Xerazade, que tenta distrair o sultão para conservar sua vida. A narração de Antenor é descontínua, começa e recomeça, como as mil e uma histórias de Xerazade, narrada por alguém que está em desespero, à beira da morte, buscando qualquer detalhe para se salvar. Antenor está preso aos menores detalhes e, por isso, coisas insignificantes ganham para ele dimensão gigantesca, já que qualquer dado é importante para salvá-lo e adiar a chegada do fim. Antenor possui outra lógica, a lógica do delírio, marcada por uma urgência de quem não quer morrer. Este universo do delírio, do surrealismo, marca o conceito deste trecho do espetáculo em que imagens surgem descontextualizadas, destacadas sem motivo aparente. Antenor também se prende a detalhes ignorados pelos sentidos comuns: cheiros e sons que ninguém repara para ele tem uma intensidade absurda. Este é o trecho do delírio do som e da imagem.

Narração de Johansen, cenas 21 a 26: Johansen é um narrador que se considera uma testemunha. Ele é o esgoto, o lixo humano que a cidade criou e espiona a vida dos vencedores, dos dominantes que criaram seus sonhos sobre os pesadelos dos excluídos. Johansen conta como se contasse a história de um crime. A concepção aqui foi trabalhar com uma linguagem expressionista, ressaltando as contradições entre luz e sombra, entre o grotesco e o sublime. As imagens estão próximas do grito e do dilaceramento total. As imagens estão próximas de um cadáver podre na calçada, de uma realidade que se desmancha em putrefação. $O$ grotesco das imagens do Velho Brueghel e de Bosch foram referências, além do expressionismo do cinema alemão e da linguagem de Meyerhold.

Narração de Fausto, cenas 27 a 30a: Fausto narra construindo um documentário. A história de Fausto é esse documentário sendo 
construído, de forma parcial, enquanto a peça transcorre. Fausto ilumina o que the interessa, da forma como lhe convém. Percebemos que ele escolhe e manipula seus conteúdos, para dizerem o que ele quer dizer. Era importante revelar que, para além do que é iluminado pela câmera de Fausto, outras coisas aconteciam. A concepção foi a da montagem dadaísta, que recorta e cola materiais antes separados, criando atritos entre imagens e conteúdos inusitados. Tudo aqui é mostrado como se houvesse sido recortado e colado, como numa obra dadá ou na fabricação de um filme. Os gestos dos atores são citados: há espaços entre eles e não há fluidez. Há formas diferentes de representação, justapostas, formando um todo com cara de retalho.

Narração de Maribel, cenas 30a até o fim da peça: Maribel narra utilizando uma luz de flash. Maribel conta a partir do fluxo da memória, descontínuo como o acender e o apagar da luz, além do fato do flash remeter à fotografias da indústria cultural, ao sucesso. O universo de Maribel é formado pelas regras da memória: fluxo inconstante, diferentes formas de tempo (velocidades de movimento), associações imprevistas, imagens que se dissolvem, antigas cantigas que surgem sem motivo, saltos, elipses. Maribel conta a história de alguém que venceu: por isso as cenas alternavam momentos pesados e sofridos com momentos de euforia e otimismo ${ }^{155}$.

A dramaturgia da luz procurou, como pode-se ver na descrição acima, diferenciar os narradores a partir de iluminações distintas propostas para as cenas narradas por cada um dos personagens. No plano da luz, esta diferenciação ocorreu. No entanto, na construção dos personagens narradores esta determinação e demarcação de fronteiras é difícil de ser realizada. A definição proposta pela iluminação não corresponde aos terrenos subjetivos em deriva, marcados pelos personagens. Este acúmulo de diversas vozes presentes na voz cada personagem narrador, gerando atitudes incoerentes e ações por vezes incompreensíveis, deu às cenas presentes em cada narrativa contada um aspecto caótico e de difícil diferenciação, o que desmentia esta dramaturgia da luz tão clara nos seus movimentos.

É importante observar que, ao contrário do teatro épico que constrói seus personagens a partir da noção de indivíduo, e ao contrário do que Lehmann batizou de teatro pós-dramático, que se baseia na negação do sujeito, a forma labiríntica de Miopia estaria igualmente distante da noção de indivíduo clássica, mas teria seus narradores dependentes da noção de "consumidor".

Se retomarmos a reflexão de Gilles Deleuze já mencionada anteriormente, com a substituição da sociedade disciplinar, que fracionava o indivíduo, criando contradições

${ }^{155}$ Idem, p. 216. 
entre os seus desejos individuais e os imperativos do mundo panóptico, pela sociedade de controle, surgiria um novo sujeito, o sujeito do capitalismo tardio, marcado pela colonização de seus desejos mais íntimos. Um exemplo de personagem da sociedade disciplinar, fracionado pelo panóptico, característica do antigo capitalismo, seria a Marie da peça Na selva das cidades, de Brecht:

Quanto a mim, estou sem fôlego. Eu estou como cortada em duas, rasgada. As paredes parecem de papel, a gente não consegue respirar. É preciso botar fogo em tudo. Onde estão os fósforos, uma caixa preta enorme, para que as águas possam inundar tudo. Ah, se as águas me levassem, o meu corpo se dividisse em dois, as duas metades de mim, seriam levadas para direções diferentes. ${ }^{156}$

Essa sensação de fracionamento, essa necessidade de destruir-se e de destruir as relações que o cercam marcaria o sujeito da modernidade. A inundação mencionada por Marie, em vias de acontecer, parece que já ocorreu. Miopia retrata este mundo pósinundação e colonização dos desejos. O sujeito moderno foi caracterizado pela noção de indivíduo. Um indivíduo contraditório, marcado pelas duas metades descritas por Marie, mas capaz de definir o seu próprio Eu. Seria possível ler nos labirintos de Miopia, nas variações de vozes que marcam cada narrador, reflexos da ultramodernidade, estágio artístico do capitalismo tardio, em que a noção de indivíduo agoniza. O sujeito/narrador presente em Miopia não seria mais responsável por seus atos e desejos, definição que sempre caracterizou o indivíduo burguês. Seus sonhos, impulsos e atitudes aparecem colonizados pelas mercadorias:

31. O MERCADOR
BELMIRO - Todos estão órfãos das propagandas que o cinema
não exibe mais. E tudo continua como sempre foi. Se as pessoas
insistem em imaginar que sem as propagandas é impossível viver,
alguém tem que lucrar com isso. Tudo continua igual. Com
exceção de que as pessoas estão fechadas em suas casas
imaginando que estão se transformando em bonecos. E continuo eu
mesmo, longe de ser um boneco. Enquanto existir alguém esperto o
suficiente para ganhar dinheiro vendendo a própria alma, tudo vai
continuar como está. Eu vendo máscaras contra a peste. Máscaras
que eu fabriquei, ou que eram máscaras antigás há alguns dias
atrás. Eu entrego comida, afinal as pessoas precisam comer e os
comerciantes precisam vender, mesmo sem sair de casa. (Bate em
uma janela: Maribel abre e lhe entrega mel. Belmiro entrega em
outra janela, onde retira dinheiro como pagamento. Devolve à
primeira janela o dinheiro e recebe uma parte.) Eu não paro o dia
inteiro. Entrego documentos e ofícios. As pessoas continuam
precisando trabalhar, continuam precisando dos seus salários e eu

${ }^{156}$ BRECHT, Bertolt. Na selva das cidades. In: Teatro completo. São Paulo: Civilização Brasileira, 1997, p. 56. 
vendo muito caro os meus serviços. ${ }^{157}$

Na cena acima, Belmiro narra a situação da cidade após o surgimento da peste imaginária. A repetição das frases "tudo continua igual”, "tudo continua como sempre foi”, quase que como um bordão, não determina uma voz que lhe pertence: são frases ditas por Antenor anteriormente, durante sua narração. Antenor é um retardado mental transformado pela prefeitura de Miopia no torturador e carrasco oficial da cidade. Assim, a repetição das frases de tal personagem torna a narração de Belmiro desconfiável: quem, de fato, está falando nesta cena? Que situação narra, de fato, esta cena? O que tal narrador representa?

Para Lehmann, o sujeito do teatro pós-dramático é representado por um personagem e por um ator que não representam, que não estão em relação com o espaço ficcional da narrativa:

A "não atuação" se refere a uma presença na qual o ator não faz nada para reforçar a informação transmitida por sua atividade (por exemplo, os auxiliares de cena no teatro japonês). Não estando vinculado à matriz de um contexto de representação, ele se encontra aqui numa situação de "atuação sem matriz". Na etapa seguinte, denominada "matriz simbolizada", Kirby se refere a um ator que manca como Édipo. Mas ele não representa o ato de mancar: é obrigado a isso por uma tala em sua calça. Portanto, ele não imita o ato de mancar, mas apenas realiza uma ação. ${ }^{158}$

A mímesis, assim, a imitação do real, não faria parte do horizonte do teatro pósdramático: o teatro pós-dramático seria aquele capaz de abolir a unidade de tempo com início e fím como moldura fechada da ficção teatral a fim de conquistar a dimensão do tempo partilhado por atores e público como processualidade aberta, que estruturalmente não possui nem início, nem meio, nem fim. A nova concepção do tempo partilhado considera o tempo estruturado esteticamente e o tempo realmente vivido como um mesmo devir que os frequentadores e os atores compartilham.

De forma contrária, a definição aristotélica de mímesis, que subsidia para Lehmann todos os procedimentos das obras teatrais que se enquadram no seu conceito ampliado de drama, ressalta, em oposição a Platão, o ganho trazido pela mímesis ao conhecimento, pois o que é conhecido não é tanto o objeto reproduzido enquanto tal era a exigência aporética de Platão - mas muito mais a relação entre a imagem e o objeto. O momento específico e prazeroso do aprendizado por meio da mímesis estaria

${ }^{157}$ ALMEIDA, Ligia Marina; DELMANTO, Ivan; FARIA, Fernanda, et al. Miopia. Inédito, 2006, p.34.

${ }^{158}$ LEHMANN, Hans-Thies. O teatro pós-dramático. São Paulo: Cosacnaif, 2007, p. 224 e 225. 
na produção dessa relação. Isso também explicaria o prazer em ver representados objetos que, normalmente, seriam repugnantes:

Ao que parece, duas causas, e ambas naturais, geraram a poesia. $\mathrm{O}$ imitar é congênito no homem (e nisso difere dos outros viventes, pois, de todos, é ele o mais imitador, e, por imitação, aprende as primeiras noções), e os homens se comprazem no imitado. Sinal disso é o que acontece na experiência: nós contemplamos com prazer as imagens mais exatas daquelas mesmas coisas que olhamos com repugnância, por exemplo (as representações de animais ferozes e de cadáveres). Causa é que o aprender não só muito apraz aos filósofos, mas também, igualmente, aos demais homens, se bem que menos participem dele. Efetivamente, tal é o motivo por que se deleitam perante as imagens: olhando-as, apreendem e discorrem sobre o que seja cada uma delas e dirão, por exemplo: "esse é tal". ${ }^{159}$

Aristóteles, e o drama posterior a ele, considerariam a mímesis como parte da natureza humana, caracterizando em particular o aprendizado humano, inscrevendo-a na atividade do conhecer. O aprendizado mimético, diz Aristóteles, produz prazer, agrada. Este momento de prazer não é interpretado como um desvio perigoso da essência, como em Platão, mas, pelo contrário, como um fator favorável, que estimula e encoraja o processo de conhecimento, ganhando importância o lúdico. Ao descrever esse ganho de conhecimento, Aristóteles insiste na sua característica de "reconhecimento". Esta valoração da atividade mimética como identificadora de semelhanças permitirá a Aristóteles definir mais adiante a mímesis da seguinte maneira: "Quando no poeta se repreende uma falta contra a verdade, há talvez que responder como Sófocles: que representava ele os homens tais como devem ser, e Eurípides, tais como são". ${ }^{160}$

A afirmativa de que objetos e eventos devem ser mostrados, não como são, mas como "deveriam ser" é central para o desenvolvimento das ulteriores estéticas teatrais normativas, sendo levada a sério, séculos depois, por teóricos e dramaturgos durante a emergência do drama burguês, que, segundo Szondi:

Em relação ao gênero do drama burguês, o acento sobre o mérito patriótico dos comerciantes também é da maior relevância, bem como a equiparação com o nobre que se deriva daí (...) $\mathrm{O}$ comerciante age como instrumento da razão, na medida em que corrige sobre a terra a distribuição natural e, por assim dizer, irracional dos bens. (...) Levar à ordem a desordem natural constitui a tarefa do mercador. ${ }^{161}$

A partir de uma análise do drama $O$ mercador de Londres, de Lillo, Szondi

\footnotetext{
${ }^{159}$ ARISTÓTELES. Poética. In: Os Pensadores. São Paulo: Abril Cultural, 1977, p. 241.

${ }^{160}$ Idem, p. 266.

${ }^{161}$ SZONDI, Peter. Teoria do drama burguês. São Paulo: Cosacnaify, 2004, p. 64.
} 
identifica como surgimento da tradição teatral burguesa a abolição da cláusula dos estados e, com a entrada do comerciante em cena, a afirmação dos ideais burgueses como função primordial da mímesis teatral do período. Assim, os comerciantes do drama de Lillo não são imitados em sua "verdadeira" condição mas apresentados como “deveriam ser”, como portadores de uma missão social progressista. Tal compromisso civilizador do teatro e da mímesis, seria retomado tempos depois por Brecht que, ao contrário do que se costuma propagar, tem uma relação de negação mas também de conservação em relação à mímesis aristotélica:

Necessitamos de um teatro que não nos proporcione somente as sensações, as ideias e os impulsos que são permitidos pelo contexto histórico das relações humanas (o contexto em que as ações se realizam), mas, sim, que empregue e suscite pensamentos e sentimentos que desempenhem um papel na modificação desse contexto. (...) Concordamos com Aristóteles quanto a considerar a fábula o cerne da tragédia, mas discordamos dele no que respeita ao objetivo a que deve obedecer a sua representação. (...) O objetivo da estilização é revelar ao público, que é uma parte da sociedade, tudo o que, na fábula, é importante para a transformação da sociedade. ${ }^{162}$

A representação estilizada de que fala Brecht é aquela capaz de produzir um efeito de estranhamento sobre o material imitado: "uma reprodução estranhada é aquela que permite reconhecer um objeto, mas fazendo ao mesmo tempo que apareça como estranho". Assim, Brecht dá novo sentido à mímesis sistematizada por Aristóteles, mantendo o seu encadeamento fabular, mas buscando uma representação que negue e afirme a imitação do real ao mesmo tempo, sendo então capaz de "apresentar a sociedade como mutável", como esta deveria ser (re)conhecida.

Lehmann, exatamente para expor a morte destas concepções de mímesis que caracterizaram o teatro dramático e épico, menciona a performance como referência a este novo teatro (outros teóricos como Josette Féral preferem substituir a denominação de pós-dramático por teatro performativo, exatamente para sublinhar as origens de tal forma teatral contemporânea):

O próprio performer pode se oferecer como vítima de um sacrifício; o público pode ser culpabilizado por sua experiência participativa e passar a ter ele mesmo o papel de vítima, a performance pode se transformar em automanipulação que chega ao extremo do suportável. (...) Com efeito, a concepção da autotransformação convida a considerar como o ponto de vista

${ }^{162}$ BRECHT, Bertolt. Escritos sobre teatro, vol. 2. Buenos Aires: Nueva Visión, 1974, p. 183-201. 
radical da performance o suicídio em público. ${ }^{163}$

No teatro ocidental desde Aristóteles, construído sobre a ideia de mímesis e de representação, o efeito da catarse permanece virtual, voluntário e futuro, já o ideal da performance ou do teatro pós-dramático é um processo real, que impõe emoções e acontece aqui e agora. Segundo Féral:

A noção de performance valoriza a ação em si, mais que o valor de representação, no sentido mimético do termo. O teatro está inexoravelmente ligado à representação de um sentido, passe pela imagem ou pela palavra. O espetáculo nele segue uma narrativa, uma ficção. Ele propõe ali um sentido, um significado. ${ }^{164}$

Já para Eleonora Fabião, é possível identificar algumas caraterísticas comuns à performance e também a certo teatro performativo:

7) o desinteresse em performar personagens fictícios e o interesse em explorar características próprias (etnia, nacionalidade, gênero, especificidades corporais), em exibir seu tipo ou estereótipo social (ou convidar transeuntes para que apalpem seus seios através das cortininhas de uma maquete de palco italiano); 8) o investimento em dramaturgias pessoais, por vezes biográficas, onde posicionamentos e reivindicações próprias são publicamente performados (como o sexo anal com um pênis-barbie); (...) 14) a ampliação dos limites psicofísicos do performer (seja se desfigurando ao feder abjetamente em espaços públicos, ou subindo uma escada de luminosos degraus). ${ }^{165}$

O que há de comum nas características apontadas por Lehmann, Féral e Fabião diz respeito ao caráter letal desta espécie de teatro: a forma teatral é tensionada aos seus limites, a ponto de termos em cena a apresentação da morte da própria ideia de teatro. Todas as características citadas acima destroem mais do que categorias como personagem, narrativa e ficção, destroem também a ideia de que a arte teatral é mímesis: a encenação performativa, ao preocupar-se com a ação que ocorre no aqui e agora da apresentação não procura imitar ou representar uma ação, mas busca realizá-la, no corpo do ator performer:

Chamo as ações performativas programas pois, neste momento, esta me parece a palavra mais apropriada para descrever um tipo de

\footnotetext{
${ }^{163}$ LEHMANN, Hans Thies. O teatro pós-dramático. São Paulo: Cosacnaify, 2007, p. 231.

${ }^{164}$ FÉRAL, Josette. Por uma poética da performatividade: o teatro performativo. Revista Sala Preta: São Paulo: ECA-USP, 2009, p. 12.

${ }^{165}$ FABIAO, Eleonora. Performance e Teatro: poéticas e políticas da cena contemporânea. In:

Cartografias do Ensino de Teatro (org.) Adilson Florentino e Narciso Telles, editora Edufu (no prelo).
} 
ação metodicamente calculada, conceitualmente polida, que em geral exige extrema tenacidade para ser levada à cabo, e que se aproxima do improvisacional exclusivamente na medida em que não será previamente ensaiada. Performar programas é fundamentalmente diferente de lançar-se em jogos improvisacionais. O performer não improvisa uma ideia: ele cria um programa e programa-se para realizá-lo (mesmo que seu programa seja pagar alguém para realizar ações concebidas por ele ou convidar espectadores para ativarem suas proposições). Ao agir seu programa, des-programa organismo e meio. A inspiração para a inserção da palavra-conceito "programa" na teoria da performance vem do texto "Como criar para si um corpo sem órgãos" de Gilles Deleuze e Félix Guattari onde propõe-se que o programa é "motor de experimentação". Um programa é um ativador de experiência. Longe de um exercício, prática preparatória para uma futura ação, a experiência é a ação em si mesma. ${ }^{166}$

Já na forma labirinto de Miopia não há "programa” e ainda há mímesis, mesmo que em processo de soterramento: há uma dramaturgia textual, uma narrativa e personagens definidos, por mais que a encenação dissolva e desloque estas categorias. Há referências a uma realidade que estaria sendo representada, mas os índices desta realidade são o tempo todo embaralhados: na cena final, por exemplo, há um mesmo texto dito por dois personagens diferentes, embaralhando a distinção entre os indivíduos; um coro tem como corpo ou figurino, não se sabe ao certo, um latão de lixo com rodinhas; uma personagem é soterrada, sem que se saiba ao certo se a imagem da terra é uma alegoria ou refere-se a uma ação presente na dramaturgia, como a implosão do cinema. As categorias abolidas pela performance e pelo pós-dramático, no seu programa de assassinato da mímesis, estão presentes e não estão presentes em Miopia, a dramaturgia textual é desmentida todo tempo pela encenação, sem que se consiga identificar precisamente a que paradigma formal tal teatro se refere.

Por tudo isso, o antigo indivíduo fracionado em dois aparece pulverizado por uma infinidade de desejos conflitantes que ele não sabe sequer identificar em si mesmo. O consumidor não é mais responsável por suas escolhas: sua subjetividade danificada é habitada pelos imperativos da forma mercadoria estetizada em avalanche pela indústria cultural, gerando personagens incapazes de ação e de diálogo. As figuras que habitam o labirinto são novelos de desejos, linhas embaralhadas como o Odradek de Kafka, e não podem ser lidas sob as rubricas do drama, do teatro épico ou do pós-dramático: ação, conflito, linearidade, ausência de representação.

Se retomarmos o último “diálogo da peça”, entre Maribel e sua mãe Mércia,

\footnotetext{
${ }^{166}$ Idem, ibd.
} 
talvez seja possível precisar esta subjetividade danificada:

MARIBEL(com um megafone, lá fora) - Mãe, sou eu.

Sai daí, por favor. Não vale a pena. O futuro chegou e quer entrar. Eles vão demolir o cinema. Saia daí, mãe. Por favor. Não vale a pena.

A demolição começa. Mércia é enterrada viva.

MÉRCIA - EU NÃO QUERO MAIS CONTAR

Eu abandono tudo. Então eu nego. Eu nego a história dos que pisam o chão cheio de vítimas. Eu estou do lado dos soterrados. E até que tenhamos uma história de futuro para contar, eu estou aqui, sob o chão, ao lado das vítimas, negando tudo o que existe como é. Que venha então o pesadelo. Nós o olhamos debaixo. Que venha o pesadelo. Porque do pesadelo pode-se acordar.

nenhuma resposta terminar nenhuma resposta posso me engasgar nenhuma resposta afundar nenhuma resposta não mais conspurcar a lama nenhuma resposta o escuro nenhuma resposta não mais perturbar a paz nenhuma resposta o silêncio nenhuma resposta morrer nenhuma resposta

MARIBEL - Mãe! Nenhuma resposta. Mãe! Nenhuma resposta. Nenhuma resposta. Esse é o fim é como é como não pode ser é o fim como é. ${ }^{167}$

Maribel, que está com um megafone do lado de fora do cinema que será demolido, inicia o diálogo com frases que não parecem pertencer-lhe: "O futuro chegou e quer entrar". Durante a encenação, esta frase era dita por Maribel e gravada ao mesmo tempo no megafone, que permanecia repetindo-a indefinidamente, durante todo o transcorrer da cena, como uma espécie de sujeito automático. O "diálogo" continua com os gritos de Mércia, que parece não responder à filha, mas falar ao público: "Eu não quero mais contar”. A ausência de comunicação entre as duas, que não reagem e se modificam perante as frases escutadas e proferidas, remete àquela imobilidade que já descrevemos acima. O texto final de Mércia, retirado do Como é de Beckett, era pronunciado enquanto grande quantidade de terra caía do teto da usina sobre a atriz, que terminava de dizer o texto enquanto era soterrada.

O texto de Mércia parece então contaminar Maribel: este é o único diálogo possível entre as duas, o da repetição: Maribel passa a reproduzir a fala de Mércia que, por sua vez, reproduzira o texto de Beckett. É importante observar que a parte final da peça é narrado por Maribel. Em uma cena anterior, Maribel começa assim sua narrativa:

MARIBEL - Eu testemunhei a demolição do cinema. E fotografei

${ }^{167}$ ALMEIDA, Ligia Marina; DELMANTO, Ivan; FARIA, Fernanda, et al. Miopia. Inédito, 2006, p. 40. 
Só eu sou a memória da peste imaginária que assolou Miopia Porque só eu tenho a memória do meu fracasso espelhando o fracasso da cidade.

Só eu tenho a memória e o segredo de como vencer o fracasso.

Só eu posso contar o que esta cidade me causou

Porque o meu rosto é o rosto desta cidade.

No final, eu venci. Eu e o meu rosto,

A cidade,

Vencemos.

E para que todos vençam, vou contar ${ }^{168}$.

Desta forma, quando, cenas adiante, na última fala da peça, a própria narradora assume a impossibilidade de articulação de sentido ("Nenhuma resposta Esse é o fim é como é como não pode ser é o fim como é"), o soterramento parece atingir também a narrativa. Esta sinfonia de vozes alheias, em que não se identifica a autoria das ações, das frases e dos gestos, é a imagem final de Miopia, que, ao fim do percurso, parece ter soterrado qualquer tentativa de se realizar uma narrativa mimética nos moldes do teatro épico.

${ }^{168}$ ALMEIDA, Ligia Marina; DELMANTO, Ivan; FARIA, Fernanda, et al . Miopia. Inédito, 2006, p. 33. 


\section{Saída interrompida 4: lógica protestante, dialética, estranhamento e cinismo/Quarta crise}

Cavei uma vala de um cúbito em ambas as [direções, e em seu redor verti uma libação para todos os [mortos, primeiro de leite e mel, depois de vinho doce, e em terceiro lugar de água, polvilhando com [branca cevada.

Ofereci muitas súplicas às cabeças destituídas de [força dos mortos (...)

Tomando as ovelhas, degolei-as por cima das [valas,

E o negro sangue turvo correu; e vieram

Do Érebo as almas dos mortos que partiram, Todos vinham para a vala de todas as direções, Com alarido sobrenatural; e o pálido terror me [dominou. ${ }^{169}$

As alegorias são no reino dos pensamentos o que são as ruínas no reino das coisas. ${ }^{170}$

\section{IV.1. Crise do teatro épico no Brasil e olhar petrificante: lógica protestante, dialética e estranhamento.}

É possível perceber no processo de criação de Miopia uma constante problematização dos procedimentos épicos estudados durante o processo de criação, à luz de uma realidade brasileira que parecia, a todo o tempo, esvanecer, incapturável pela forma: como fazer teatro épico em um momento histórico em que a volubilidade da classe dominante, as relações de favor, o trabalho precarizado e o desemprego convivem com a noção de consumidor? É como se essa convivência bizarra, “ornitorrínquica”, fosse parte de um processo histórico em que sequer a noção de indivíduo, fundamental aos avanços e recuos do teatro europeu, tivesse sido

\footnotetext{
${ }^{169}$ HOMERO. Odisseia. Lisboa: Cotovia, 2003, p. 180.

${ }^{170}$ BENJAMIN, Walter. Origem do drama trágico alemão. Lisboa: Assírio \& Alvim, p. 192.
} 
completada.

O espetáculo Miopia pode ser compreendido sob esta luz difusa do processo histórico brasileiro. E os procedimentos formais que o caracterizam não se encaixam nas rubricas do drama, do teatro épico ou do teatro pós-dramático, modelos que correspondem ao desenvolvimento do capitalismo nos países centrais. Para lermos Miopia, como Orfeu, será necessário olhar melancolicamente para trás, transformando nosso objeto em pedra. Sob este olhar, é possível ver que Miopia pode ser entendida a partir da experiência dramatúrgica de um escritor que, ao defrontar-se com um modelo do processo histórico europeu, o teatro épico, teve que buscar uma forma própria para dar conta do desenvolvimento histórico brasileiro: Oduvaldo Vianna Filho.

Em um pequeno texto em que discute nova designação para o seu "teatro épico", Bertolt Brecht considera tal nomenclatura muito geral e indeterminada, apenas formal. Segundo ele, "na atualidade se está intentando passar do teatro épico ao dialético". Assim, o teatro dialético não negaria o teatro épico, mas o suspenderia. A forma e o conteúdo do teatro dialético partiriam do pressuposto de que o mundo pode ser representado através da contradição. Brecht tinha em destaque em uma de suas mesas de trabalho durante o exílio uma citação de Hegel: “em geral, o que move o mundo é a contradição; e é ridículo dizer que a contradição não se deixa pensar" ${ }^{\text {"171 }}$. Para Brecht, o teatro dialético busca descobrir os fenômenos e as contradições que escondem, o que os faz mudar e evoluir no tempo. O teatro se torna assim forma estética e cognitiva, experiência sensível e pedagogia da contradição, método prático de se descobrir, enquanto se age, as contradições da realidade e de revelá-las sob forma estética. Revelar as contradições de uma realidade para Brecht é historicizá-la, conceito chave durante o processo de criação de Miopia, na medida em que historicizar um fato é revelar suas dimensões não naturais, passíveis de modificação, apontando em cada situação suas conexões sociais e mutáveis.

A primeira pergunta que envolveu a definição do processo de investigação que criaria Miopia girou em torno do teatro épico e dialético:

Em que medida o teatro dialético supera os pressupostos sistematizados por Brecht anteriormente e chamados de maneira mais geral de teatro épico? Mais: qual a validade de tais pressupostos dialéticos hoje, no Brasil de 2005, em uma Usina de

\footnotetext{
${ }^{171}$ HEGEL,G.W.F. Enciclopédia das ciências filosóficas: a ciência da lógica. Rio de Janeiro: Loyola, 1995 , p. 233
} 
Lixo na periferia de São Paulo? ${ }^{172}$

Na escolha do tema e material de pesquisa para a construção do espetáculo - a chamada "Intentona Comunista de 1935" -, Leandro Konder tornou-se a referência inicial deste primeiro momento de trabalho, apontando, em A derrota da dialética, como a apropriação das ideias de Marx no Brasil foi feita sob o império do positivismo ou, nas palavras de Lênin, do "materialismo imbecil”, moldando seus fracassos e ruínas. Para o grupo, no início do processo de criação, o período histórico de 1935 seria rico na demonstração do que uma abordagem não dialética da realidade poderia trazer à reflexão e a prática dos movimentos sociais.

Roberto Schwarz, em seu ensaio Altos e baixos da atualidade de Brecht, aponta que a linguagem nua dos interesses e das contradições de classe, que imprime a nitidez especial à obra de Brecht, não teria equivalente no imaginário brasileiro, pautado pelas relações de favor e pelas saídas da malandragem:

Conforme um descompasso análogo entre as respectivas ordens do dia, o nosso zé-ninguém precisava ainda se transformar em cidadão respeitável, com nome próprio; ao passo que para Brecht a superação do mundo capitalista, assim como a disciplina da guerra de classes, dependiam da lógica do coletivo e da crítica à mitologia burguesa do indivíduo avulso"173.

As constelações históricas não eram iguais, embora a questão de fundo - a crise na dominação do capital - fosse a mesma, assegurando a formação de uma tradição épica em nosso teatro, embora formada supressivamente, como diria José Antônio Pasta Jr. Formação de uma experiência do épico entre nós que estaria caracterizada por desenvolver-se suprimindo o que para Brecht era o conteúdo essencial de seu teatro: o método dialético.

Seguindo pistas presentes no ensaio de Adorno, Engagement, Fredric Jameson indica que no teatro de Brecht o primado da doutrina atua como um elemento estético, ou que o didatismo de sua proposta é um princípio formal. Assim, o teor de verdade das peças não estaria nos ensinamentos transmitidos, nas radiografias sobre a luta de classes, mas na "dinâmica objetiva do conjunto", que teria de pedagógico o seu método de ler e expressar os movimentos do capital, método capaz de identificar contradições. O cerne da obra de Brecht estaria, portanto, na sua forma artística dialética:

\footnotetext{
${ }^{172}$ ALMEIDA, Ligia Marina; FARIA, Fernanda; DELMANTO, Ivan et al. Anjos do desespero. Projeto de pesquisa teatral. Contemplado pela V Edição da Lei de Fomento ao Teatro do Município de São Paulo. Inédito, 2005, p.11. Disponível para consulta na Divisão de Fomento da Secretaria Municipal de Cultura.

${ }^{173}$ SCHWARZ, Roberto. Sequências brasileiras. São Paulo: Cia. Das Letras, 1999, p.121.
} 
Isto significa que "a ideia de Brecht" é tão importante quanto seus textos individuais, (...) ela é distinta deles (...). Iremos portanto deslindá-la, não enquanto método em geral, mas como o "Grande Método", aquela doutrina ensinada pelo legendário Me-ti. O Grande Método brechtiano põe em cena a mesma dialética tradicional de um modo bem diverso, expondo suas dimensões metafísicas ou pré-socráticas de uma forma muito diferente do materialismo dialético de Stalin". ${ }^{174}$

Há um fragmento desta prosa dialética, um trecho da doutrina de Me-ti, personagem de uma das parábolas brechtianas, que revela em que consiste este Grande Método:

Me-ti disse: é vantajoso não simplesmente pensar de acordo com o grande Método mas também viver de acordo com o grande método. Não ser idêntico a si mesmo; aceitar e intensificar crises, transformar pequenas mudanças em grandes e assim por diante não basta apenas observar tais fenômenos, pode-se representá-los. Pode-se viver com maiores ou menores mediações, em relações mais ou menos numerosas. Pode-se almejar ou lutar por uma transformação mais durável da própria consciência através da modificação do nosso próprio eu social. Pode-se ajudar a tornar as instituições do estado mais contraditórias e portanto mais capazes de evolução." ${ }^{175}$

Esta capacidade de intensificar crises, de apresentá-las acumuladas em estado coagulado, pode ser definida como um dos traços essenciais da forma labirinto em Miopia. Os materiais e procedimentos que configuram a peça estão presentes em crise permanente. Neste sentido, há uma aproximação estreita entre o labirinto e o Grande Método. Mas se nos voltarmos para o objeto, à obra artística de Brecht expressa em seus textos individuais, é possível encontrar este seu método dialético concretizado. Vejamos uma cena, extraída do Círculo de giz caucasiano:

(Os criados se reúnem em torno do menino).

GRUSHA - Ele acordou.

MOÇO DA ESTREBARIA - Melhor é deixar ele aí. Prefiro não pensar no que pode acontecer a quem for encontrado com o menino.(...)

COZINHEIRA - Eles têm mais interesse em apanhar o menino do que a mãe. É o herdeiro, Grusha, tu és uma boa alma, mas não tens muita cabeça. Ouve o que te digo, se ele estivesse com lepra, não seria mais perigoso. Livra-te dele. (...)

PRÍNCIPE GORDO - Aqui, bem no meio. (Um soldado trepa nas costas de outro, segura a cabeça do Governador, suspende-a acima

\footnotetext{
${ }^{174}$ JAMESON, Fredric. O método Brecht. São Paulo: Vozes, 1999, p. 55.

${ }^{175}$ BRECHT, Bertolt. Narrativa completa, 3. Madrid: Alianza Editorial, 1991, p. 83.
} 
da porta principal e considera o efeito produzido.) Não está no meio! Mais à direita! Está bem! Meus amigos, quando mando fazer alguma coisa, quero que ela seja bem feita. (Enquanto o soldado, com um prego e um martelo, pendura a cabeça pelos cabelos). Hoje de manhã, à porta da igreja, eu dizia a Georgi Abaschivílli: "Gosto dos céus sem nuvens." Mas gosto sobretudo é de um raio caindo do céu, sem nuvens. Ah, sim! Pena que eles tenham levado o garoto. Preciso dele absolutamente. Procurem-no por toda a Geórgia. Mil pilastras! (...)

(Grusha carrega um embrulho e se dirige para a porta. Ao chegar perto dela, volta-se para ver se o menino ainda está lá. O Cantor principia a cantar. Ela pára, imóvel).

RECITANTE - Estando ela entre uma porta e outra, ouviu

Ou julgou ouvir um fraco apelo: o menino

Chamava-a, não choramingava, chamava-a inteligentemente,

Pelo menos assim lhe parecia. "Mulher", dizia ele, "socorre-me". (...)

(Grusha dá alguns passos, aproxima-se do menino e inclina-se para ele).

Ouvindo essas palavras, ela volta para

Olhar o menino mais uma vez. Só para durante alguns instantes

Ficar junto dele, até que venha alguém

A mãe talvez ou outra pessoa qualquer.

(Grusha senta-se em frente ao menino, apoiando-se na mala)

Antes de ela ir-se embora, pois demasiado é o perigo

E a cidade inteira

Se enche de chamas e gemidos

(A luz diminuindo como se caísse o crepúsculo e a noite. Grusha entra no palácio e volta trazendo uma lâmpada e leite, e dá de beber ao menino.)

RECITANTE - Terrível é a tentação do bem! ${ }^{176}$

Jameson cita a fala final do recitante nesta cena como exemplo supremo do efeito de estranhamento ${ }^{177}$ : a hesitação de Grusha antes de assumir o encargo do bebê ameaçado (herdeiro do governador deposto e portanto um evidente alvo dos revolucionários), ao ser disfarçada pelo cantor-comentador, constituiria em si mesma todo um programa: “Terrível é a tentação do bem!”. Salvo engano, entretanto, o Recitante não disfarça a hesitação de Grusha; pelo contrário, o comentário épico $a$ ressalta. O estranhamento só ocorre porque há uma interrupção da ação, que nega o sentido da cena: ao invés de reforçar o ato de bondade da futura mãe adotiva, o comentador se alia aos prenúncios fúnebres dos demais empregados e ao ponto de vista sanguinário do Príncipe Gordo. O juízo proferido é, em si mesmo, contraditório: a

\footnotetext{
${ }^{176}$ BRECHT, Bertolt. O círculo de giz caucasiano. São Paulo: Cosacnaify, 2002, p. 75.

${ }^{177}$ JAMESON, Fredric. O método Brecht. São Paulo: Vozes, 1999, p. 234.
} 
tentação da bondade torna-se terrível pecado em um mundo de "humanidade desumanizada". O método dialético de Brecht pode ser entendido nesta cena não só através do dito contraditório do narrador, lâmina afiada que faz o espectador mudar bruscamente de caminho, mas também através dos múltiplos focos narrativos que se chocam no narrar da situação: as falas do Moço da Estrebaria, da Cozinheira e do Príncipe Gordo contradizem o ponto de vista generoso de Grusha, a quem o público seria na forma dramática levado a se identificar. O Recitante narra as ações de Grusha enquanto estas ocorrem, aumentando a importância e a gravidade do que acontece em cena, como se estivéssemos diante de um enredo trágico. Tal tom heroico é bruscamente derrubado pela frase final, capaz de historicizar sentimentos como a bondade, a tentação pecaminosa e a maternidade. A forma épica da cena, apresentada sob olhares contraditórios, expõe uma relação dialética entre razão e emoções, e uma relação histórica entre emoções e interesses. Vale notar ainda a riqueza da encenação proposta pelas rubricas, em que o vagar tonto de Grusha em frente à porta do palácio, acompanhado do cair lento do crepúsculo, proposto para a iluminação, compõe a paisagem obscura da decisão trágica, sendo depois subitamente iluminada pela luz dialética da contradição final.

Esta luz dialética não conseguiu, parece-nos, atingir com força nossas terras obscurantistas. Ou, melhor dizendo, com a chegada do teatro épico no Brasil torna-se luz difusa por aqui, gerando uma forma teatral híbrida, capaz de revelar nossas contradições históricas a contrapelo, em uma espécie de dialética sem síntese, ou de uma forma trágica feita de opostos promíscuos, em um épico ornitorrínquico. À guisa de prefácio, fiquemos apenas com a tradução do Círculo de giz empreendida por Geir Campos, uma das únicas publicadas até hoje no Brasil. A mesma cena citada acima na tradução de Manuel Bandeira, poeta especialista nos sentimentos dos contrários, termina assim, na tradução de Geir Campos:

\section{CANTOR - Que poder fabuloso tem a vocação da bondade! ${ }^{178}$}

Notem que toda a força contraditória do comentário se perde nesta versão. Os contrários: terrível, tentação e bem são substituídos por uma frase que reforça o sentido primeiro da cena, transformando o efeito de estranhamento dialético em um vazio lugar

\footnotetext{
${ }^{178}$ BRECHT, Bertolt. O circulo de giz caucasiano. In: Teatro Completo, vol. 9. Rio de Janeiro: Paz e Terra, 1992, p. 209.
} 
comum. A substituição de terrível por poder fabuloso e de tentação por vocação parece exemplificar a dificuldade que o teatro dialético de Brecht teria para se estabelecer no Brasil, por mais contraditório que este efeito de apaziguamento possa parecer, em uma sociedade fraturada por contrários irreconciliáveis.

Nosso olhar petrificante para o passado continuará com a análise da peça $O s$ Azeredo mais os Benevides de Vianinha, iluminando esta transformação do método dialético que aclimatou o teatro épico por aqui. Escolhi esta peça para discutir a recepção do teatro épico no Brasil por sua condição de obra fraturada por extremos e excessos, sendo, exatamente por sua incompletude, capaz de condensar em sua forma diversos impasses da transformação do épico em nosso teatro. Segundo Iná:

Dando continuidade à crítica, presente em Brasil, versão brasileira, à aliança de classes, nessa peça Vianinha expõe seus resultados através do que chamou "história de uma amizade errada". Incorporando as lições de Brecht, principalmente as aprendidas em Mãe Coragem, o dramaturgo resolveu tratar seu assunto indiretamente, isto é, de forma distanciada (...) ângulo a partir do qual pode configurar, com a serenidade própria do gênero épico, uma espécie de marca registrada da história do Brasil, dando ênfase ao papel desempenhado por suas vítimas. (...) Desde a distribuição das quadras, o dramaturgo indica a sua discrepância do processo generalizado àquela altura - de mitificação da classe trabalhadora: os colonos da fazenda desenvolvem formas variadas de competição e solidariedade entre si e em relação ao patrão, armando-se o quadro onde evolui a referida "amizade errada", entre Alvimar (uma espécie de trabalhador modelo) e Espiridião (o dono das vidas)". ${ }^{179}$

Seguindo a pista acima, busquemos inicialmente em Brasil, versão brasileira, a obra do dramaturgo anterior a Os Azeredo, traços da dialética peculiar brasileira:

SLIDE 33 O símbolo da Esso perto de uma favela

SLIDE 34 O símbolo da Esso numa cidade Africana. Em cima de miséria.

SLIDE 35 Um exército de empregados da Esso com o uniforme da Esso.

SLIDE 36 Uma festa da direção da Esso nos Estados Unidos.

SLIDE 37 O símbolo da Esso gravado no mundo. ${ }^{180}$

Vianinha pretende analisar a presença do imperialismo no país, tomando como eixo o combate estrangeiro à Petrobras, aliado aos métodos do capital financeiro, para manter como reféns os assim chamados representantes da burguesia nacional. O que

\footnotetext{
${ }^{179}$ COSTA, Iná Camargo. A hora do teatro épico no Brasil. Rio de Janeiro: Paz e Terra, 1996, p. 92.

${ }^{180}$ VIANNA Filho, Oduvaldo. Brasil, versão brasileira. In: PEIXOTO, Fernando. O melhor teatro do CPC da UNE. São Paulo: Global, 1989, p. 254.
} 
chama atenção na forma da peça, é que tudo começa com a projeção de 38 slides que, como podemos ver acima, utilizam-se de procedimentos de montagem à maneira de Eisenstein para emoldurar epicamente a ação que será desenvolvida posteriormente. $\mathrm{O}$ que se vê a seguir é o desenrolar de uma narrativa de conteúdo épico mas de forma dramática: um empresário nacionalista rompe com o governo vendido ao imperialismo e a polícia avança atirando sobre os trabalhadores em greve política. O comunista ortodoxo, antagonista do empresário Vidigal, é atingido pelos tiros. Há no final uma apoteose, comum à forma dramática, em que, no enterro do herói, jovens católicos e comunistas se unem para dar continuidade à luta. A unidade de ação, com conflito desenvolvido através do diálogo intersubjetivo, expõe a narrativa que é, em alguns momentos interrompida por vozes em off, por coros e por novos slides que procuram contextualizar historicamente a história de Vidigal. O que nos interessa observar é que os planos permanecem separados e opostos: a forma dramática, o conteúdo épico e os procedimentos narrativos caminham separadamente, como se coexistissem na fatura da peça formas distintas e irreconciliáveis: o conteúdo épico, extraído da realidade brasileira, a forma dramática, sem tradição consolidada entre nós, e os procedimentos narrativos comuns ao agitprop russo e ao teatro de Erwin Piscator mas que, em seus contextos originais, transformavam os outros materiais da dramaturgia, reconfigurando o todo em formas épicas. Na peça de Vianinha, pelo contrário, a originalidade formal vem exatamente desta ausência de totalidade épica, por si só contraditória, tratando-se de um gênero que pressupõe a busca pela totalidade, já que o todo, na obra do dramaturgo brasileiro, é apresentado pela justaposição de cacos advindos de formas distintas. Há entre os materiais diversos da composição autonomia e separação, de modo que a ação dramática pode prescindir dos elementos narrativos e o conteúdo épico não tem todas as suas nuances e aspectos históricos expostos exatamente por conta da forma dramática de desenvolver a narrativa, responsável por apresentar os personagens - que de esquemáticos não chegam a configurar indivíduos -, como únicos motores da História.

Vejamos se características similares podem ser encontradas na "anti-obra-prima" do teatro épico brasileiro. Comecemos com a cena II de Os Azeredo mais os Benevides:

CORO - (Baixo, meio falado) Ah, que boa confiança

Patrão tem muita segurança

Quando existe autoridade

A gente esquece até felicidade.

MIGUEL - Ponha esse cobertor nas costas. Vosmicê parado em pé 
que Doutor Espiridião quer ver vocês prá distribuir as quadras de terra... (Todos se enfileiram, Alvimar vem vindo) Fique parado, moço...

ALVIMAR - Me dê licença, doutor, me desculpe, mas estou vendo a febre nos olhos de vosmicê... e tenho aqui na matulagem uma erva que esmigalhadinha com cabo de faca, doutor... Me dê licença... (Alvimar volta. Espiridião com febre. Com dificuldade se mantém em pé. Vai olhando.)

GONÇALINHO - Doutor, fui o primeiro a chegar aqui, me dê esse pedaço de terra que é perto do rio, sou tão velho, tão desenxabido... VELHO - Dê prá mim! Prá mim esse pedaço!...

SIÁ ROSA - Prá mim, doutor, que me chamo Siá Rosa das Dores e tirante o meu defeito de ser mulher sou feito um boi que viro uma quadra de terra num dia só, viro tão fundo que desenterro morto se tiver morto desprevenido!

VOZES - Prá mim! Doutorzinho! Me faça a graça!

ESPIRIDIÃO - Silêncio. (Faz-se silêncio. Vai até Alvimar) Como é seu nome?

ALVIMAR - Por inteiro ou só para me chamar?

ESPIRIDIÃO - Por inteiro.

ALVIMAR - É Salustiano Alvimar.

ESPIRIDIÃO - Esse pedaço de terra perto do rio fica com você, Alvimar.

ALVIMAR - Sim, senhor. (Os dois ficam parados um na frente do outro)

LINDAURA - (Canta) Uma funda amizade

Aqui começou

Um doutor de verdade

E um camponês, meu amor. ${ }^{181}$

A história de uma "amizade errada", entre o latifundiário e o camponês, é alegoria da impossibilidade de uma aliança entre classes. Se Iná Camargo apontou a influência da Mãe Coragem, de Brecht, podemos observar também, na escolha do conflito entre o proprietário da terra e seus trabalhadores a semelhança com $O$ círculo de giz caucasiano. Veremos adiante se a comparação entre a cena de Vianinha e a cena de Brecht citada acima pode ser produtiva. Por ora observemos a mesma opção alegorizante dos dois dramaturgos, já que no caso de Brecht a disputa entre a mãe biológica e a mãe adotiva de uma criança é alegoria do conflito entre proprietários de terra e trabalhadores da terra.

Ao preparar sua exposé ao trabalho das Passagens, em 1935, Walter Benjamin fez uma breve anotação: "fetiche e caveira". De modo geral, através de todo o material das Passagens e do livro sobre o drama barroco alemão, a imagem da ruína é vista como

\footnotetext{
${ }^{181}$ VIANNA Filho, Oduvaldo. Os Azeredo mais os Benevides. Rio de Janeiro: MEC/SNT, 1968, p.17-18.
} 
emblema da fragilidade da cultura capitalista e também de sua transitoriedade:

\begin{abstract}
A história em tudo o que nela desde o início é prematuro, sofrido e malogrado, se exprime num rosto - não, numa caveira. (...) Nisso consiste o cerne da visão alegórica: a exposição barroca, mundana, da história como história mundial do sofrimento, significativa apenas nos episódios do declínio. Quanto maior a significação, tanto maior a sujeição à morte, porque é a morte que grava mais profundamente a tortuosa linha de demarcação entre a physis e a significação (...). A significação e a morte amadureceram juntos no curso do desenvolvimento histórico, da mesma forma que interagiam, como sementes, na condição pecaminosa da criatura, anterior à Graça. ${ }^{182}$
\end{abstract}

A dialética é o princípio constitutivo da alegoria; nela, a significação e a morte amadurecem juntas. Para os autores barrocos, a alegoria é uma figura emblemática que serve para tipificar a natureza dilacerada e catastrófica do mundo humano. A alegoria revelaria a antinomia das coisas, em que "cada pessoa, cada coisa, cada relação pode significar qualquer outra". A ambiguidade e a multiplicidade podem ser consideradas as marcas essenciais da concepção alegórica, em que a ambiguidade não passa da "riqueza do desperdício". A marca da alegoria seria assim o distanciamento das coisas do seu sentido original, a alienação das coisas da sua verdadeira essencialidade, na medida em que allo-agorein significa dizer outra coisa; ela é a afirmação da diferença sem qualquer perspectiva de reconciliação. A substituição do simbólico pela alegoria é seguida pela alienação das coisas em relação ao seu si mesmo. Enquanto o símbolo indica a busca da pureza de significação através de uma evidência de sentido, a alegoria afirmaria um abismo entre o sentido das coisas e as próprias coisas, ela nasceria e renasceria da fuga perpétua de um sentido último. No universo da alegoria não existe mais ponto fixo e imutável, nem no objeto, nem no sujeito da interpretação alegórica, que garanta a verdade do conhecimento.

E assim como os dramaturgos barrocos não só viam na ruína o fragmento significativo, mas também a determinação objetiva para sua própria construção poética, cujos elementos jamais se unificavam em um todo integrado, podemos ver em $O s$ Azeredo uma construção de ruínas, um acúmulo de fragmentos que formam e não formam uma peça épica: que formam, se é que se pode formar algo assim, um épico antiépico, um épico antitético, construído sobre as bases esmigalhadas das contradições. É como se a experiência histórica do barroco alemão pudesse ser lida por um autor brasileiro do século XX, que queria escrever teatro épico, construção de bases sólidas,

${ }^{182}$ BENJAMIN, Walter. Origem do drama trágico alemão. Lisboa: Assírio \& Alvim 2007, p.188. 
como podemos ver na totalidade geométrica do Círculo de giz de Brecht, antítese da ruína barroca.

O teatro épico antiépico de Os Azeredo nos apresenta uma forma ornitorrínquica. Logo ao analisarmos sua fachada, a fábula, percebe-se que o tema da impossibilidade da aliança de classes é tratado sempre no âmbito da família. A ação da peça inicia-se com uma discussão sobre os rumos que o primogênito da família, Espiridião, deve tomar: por fim, ele recusa um casamento arranjado para cuidar das terras abandonadas da família, cultivando cacau na Bahia. A amizade entre Espiridião e Alvimar - o dono das terras e o seu trabalhador predileto -, une também as duas famílias, gerando, mais adiante, uma disputa pelo filho do agricultor que, criado algum tempo na cidade com a família do patrão, não quer mais viver a vida miserável dos pais.

Peter Szondi, em análise empreendida sobre o gênero dramático no seu Teoria do drama burguês, assinala que no drama "o canto da musa da tragédia é substituído por seu lamento". A característica principal do efeito deste gênero teatral seria eliminar a distância social entre personagens e o público, causando compaixão. A sentimentalidade torna-se um dos aspectos fundamentais do drama, desenvolvendo uma técnica de comoção bastante eficaz:

Não é a condição burguesa das dramatis personae por si só, mas sim um tema ou motivo especificamente burguês que faz uma obra aparecer como drama burguês. Assim, não se elimina apenas a dificuldade terminológica de que é possível escrever dramas burgueses a respeito de nobres e até mesmo de reis. (...) Que nos dramas burgueses não apareçam somente burgueses, que a cláusula dos estados não seja quebrada tanto a favor da condição burguesa, mas também porque as ideias relativas à condição sejam substituídas por outras, relativas à sentimentalidade, nas quais é decisiva a oposição entre o privado e o público, e não a oposição entre burguesia e aristocracia. ${ }^{183}$

Se é possível escrever dramas burgueses a respeito de nobres e de reis, é possível escrever dramas burgueses a respeito de operários e de lavradores. Não é propriamente o que ocorre com Os Azeredo, que não pode ser classificada de drama burguês, mas que pode sim ser analisada em sua característica formal bastante contraditória: a de conjugar aspectos épicos à sentimentalidade e à representação de uma sociabilidade em que o mundo privado surge separado do público. Comparando a transição europeia da forma dramática para o teatro épico a partir de Brecht, Szondi aponta que, pela inserção de elementos econômicos e pelo deslocamento do acontecimento dramático da esfera da

${ }^{183}$ SZONDI, Peter. Teoria do drama burguês. São Paulo: Cosacnaify, 2004, p. 89-90. 
ação dramática efetuada por personagens individuais para a esfera do processo social supraindividual, que precisa ser representado como processo social, ocorre uma modificação formal. A peculiaridade da forma de Os Azeredo reside na simultaneidade na representação da esfera privada e familiar e de processos sociais supraindividuais, sem que haja trânsito e diálogo entre estes aspectos, resultando em uma espécie de dialética estagnada. Esta simultaneidade formal do público e do privado, do épico e do dramático, como duas faces de uma moeda que nunca se encontram, talvez expresse aspectos bastante específicos da sociedade brasileira.

Para Max Weber, as burocracias são essencialmente sistemas de normas. A figura da autoridade é definida pela lei, que tem como objetivo a racionalidade e a coerência entre meios e fins. O tipo ideal de burocracia baseia-se na formalidade e apresenta três características essenciais: as pessoas são ocupantes de cargos ou posições formais, com alguns dos cargos gerando figuras de autoridade. A obediência é devida aos cargos, não aos ocupantes, e todas as pessoas seguem a lei. A burocracia tem como segundo princípio a impessoalidade: as burocracias são formadas por funcionários que, como fruto de sua participação, obtêm apenas os meios para sua subsistência. Tal profissionalismo geraria a terceira e última característica essencial da burocracia: a administração burocrática como a forma mais racional de exercer a dominação. Para tal, a burocracia segundo Weber refere-se a um sistema marcado pela divisão do trabalho; pela hierarquia claramente definida; por regras e regulamentos detalhados, possibilitando o exercício da autoridade e a obtenção da obediência com precisão, continuidade, disciplina, rigor e confiança.

Para o negativo de tal processo, podemos tomar Raízes do Brasil, de Sérgio Buarque de Holanda, em sua interpretação da formação política, econômica e cultural do país inspirada em uma leitura de Max Weber a contrapelo. No Brasil, as normas que regem a formação das burocracias e dos Estados europeus já nasceriam invertidas, a partir de um processo de colonização que transformou o território em um enorme entreposto comercial das nações capitalistas avançadas. Por aqui, a sociabilidade da mercadoria seria a única lei absoluta, presente desde o surgimento das estruturas de poder, unindo burocracia e a mais despudorada bandalheira, cumprindo apenas a lei do valor.

Assim, para Sérgio Buarque, os princípios da burocracia estudados por Weber, ao invés da dominação através da impessoalidade e da formalidade, gerariam no Brasil a figura do homem cordial. O homem cordial, fantasma e metáfora que permearia nossas 
relações sociais, é moeda que tem em uma face o favor e na outra a violência. A cordialidade do brasileiro alimentar-se-ia de uma estrutura de dominação baseada nas relações pessoais e no privilégio, em trocas de favores que, sob a nuvem do jeitinho, esconderiam a mais brutal crueldade, conjugando e justapondo a esfera pública ao âmbito privado sob a nuvem da cordialidade.

$\mathrm{Na}$ cena II citada acima, a amizade entre os dois personagens torna-se alegoria da amizade/inimizade entre as classes, relação que já surge corrompida pela mediação da propriedade.

A distinção entre símbolo e alegoria que Benjamin efetua no estudo sobre o drama barroco é aqui relevante. Lembremos que Benjamin rejeitava como insustentável o cânone estabelecido (baseado nas formulações de Goethe, em Máximas e Reflexões e na correspondência com Schiller) segundo o qual a diferença entre símbolo e alegoria dependia da maneira em que ideia e conceito relacionavam o particular com o geral. Não era decisiva, para Benjamin, a distinção entre ideia e conceito, mas a categoria do tempo. Na alegoria, a história aparece como natureza em decadência ou ruína, e o modo temporal é o da contemplação retrospectiva; em troca, o tempo entra no símbolo como um presente instantâneo, em que o empírico e o transcendente aparecem momentaneamente fundidos em uma efêmera forma natural. Em carta escrita a Goethe em 26 de dezembro de 1797, Schiller já via no drama tal característica simbólica, em seu apego ao presente:

A ação dramática move-se diante de mim, em torno da épica movome eu próprio. (...) Se o acontecimento move-se diante de mim, então estou rigorosamente preso ao presente sensível, a minha fantasia perde toda a liberdade, então surge e permanece em mim uma contínua intranquilidade, eu tenho de ficar sempre junto do objeto, sendo-me recusados todo o olhar retrospectivo, toda a reflexão, uma vez que sigo um poder estranho. Se me movo em torno do acontecimento, que não pode escapar-me, então posso manter um passo desigual, posso permanecer mais ou menos tempo de acordo com a minha necessidade subjetiva, posso retroceder ou antecipar etc. Isto também sintoniza muito bem com o conceito de ser passado, que pode ser pensado como estando tranquilo, e com o conceito de narrar, pois o narrador já sabe no início e no meio qual é o fim, por conseguinte cada momento da ação lhe é indiferente e assim ele mantém todo o tempo uma liberdade tranquila. O fato do poeta épico ter de tratar o seu acontecimento como inteiramente passado e o trágico o seu como inteiramente presente, é-me bastante claro". ${ }^{184}$

\footnotetext{
${ }^{184}$ SCHILLER, Friedrich. Carta a Goethe de 26/12/1797. In: GOETHE, J.W. Obra completa, vol. 1.
} Madrid: Aguilar, 1957, P. 105. 
O drama, e sua manifestação trágica de que nos fala Schiller, seria assim puro símbolo, matéria artística que através de sua presentificação absoluta representa o real. Já o drama barroco, para Benjamin, ao cristalizar procedimentos alegóricos romperia com a forma dramática fixada pela estética clássica, criando fissuras capazes de constituir o olhar épico sob o "ponto de vista da morte". O ponto de vista da morte, no drama barroco, é aquele olhar que petrifica tudo o que vê, é o olhar que dissolve a forma dramática ao fixar alegorias que se sobrepõem à unidade de ação dramática. Nas peças analisadas por Benjamin, a ação central e catalisadora do drama, o que Lukács chama de "colisão dramática", perde o seu primado e o que se vê é uma série sangrenta de movimentos mecânicos, executados por personagens que não seguem os padrões de composição aristotélicos: não apresentam traços de caráter reconhecíveis e suas ações lembram o vagar fantasmático de zumbis. Estes sujeitos assujeitados são fixados em seu trânsito perpétuo através da morte.

O estudo sobre o drama barroco argumenta que a alegoria não era de nenhuma maneira inferior ao símbolo. A alegoria não era uma mera "técnica de ilustração lúdica", mas igual ao discurso oral ou à escrita, uma "forma de expressão", em que o mundo objetivo se impunha sobre o sujeito como imperativo cognitivo e não uma eleição arbitrária do artista como recurso estético. Certas experiências (e, portanto, certas épocas) foram alegóricas, não certos poetas. Para Lukács:

Sabemos já que a imediatez do drama é a do público. E parece ser quase óbvio que os temas mais apropriados para o drama são aqueles aspectos da vida moderna (e da história) que por sua natureza são necessária e imediatamente públicos: a saber, os aspectos da vida política. (...) Temos visto que a aceitação sem luta das tendências à privatização de numerosas e importantes manifestações individuais e sociais da vida humana leva à autossupressão do drama no "teatro de câmara". Mas esta privatização é só uma fase de um processo cujo outro aspecto se revela na crescente abstração da vida política, em sua independência e autonomia aparente cada vez maior. Assim, quando o poeta dramático não supera esta separação que Marx formulou como a aparente separação de citoyen e bourgeois, quando não faz patente com base na política os fundamentos sociais mediante a plasmação de destinos humanos vivos - destinos individuais que comprendem dentro de si os traços típicos, representativos destas conexões em seu ser-aí individual - resultará que a matéria política se manterá estéril para o drama. ${ }^{185}$

${ }^{185}$ LUKACS, Georgy. La novela historica. Mexico, D.F.: Ediciones Era, 1966, p. 162. 
Para Marx, sob o capitalismo há uma "luta entre o interesse geral e o interesse particular, o divórcio entre o Estado político e a sociedade burguesa". Neste divórcio entre o Estado político e a sociedade civil:

Para o homem, como bourgeois, "a vida política é só aparência ou exceção momentânea da essência e da regra". É certo que o bourgeois (...) só permanece na vida política por um sofisma, do mesmo modo que o citoyen só por sofisma permanece judeu ou bourgeois. Mas esta sofística não é pessoal. É a sofistica do próprio Estado político. A diferença entre o homem religioso e o cidadão é a diferença entre o comerciante e qualquer cidadão, entre o trabalhador e o cidadão, entre o latifundiário e o cidadão, entre o indivíduo vivendo e o cidadão. A contradição entre o homem religioso e o homem político é a mesma contradição que existe entre o bourgeois e o citoyen, entre o membro da sociedade burguesa e sua aparência política. ${ }^{186}$

Tal contradição é percebida por Lukács em sua análise do drama, mas o filósofo húngaro não situa o fracionamento da esfera pública, acentuado na medida em que o capital circula e coloniza todos os âmbitos da vida social, como fracionamento e dissolução da própria forma dramática. Lukács não percebe que a "autossupressão do drama no teatro de câmara" não é apenas uma opção artística dos dramaturgos a partir do naturalismo mas é sim uma incapacidade do drama enquanto forma de expressar acontecimentos de uma esfera social pública cada vez mais complexa em suas contradições e dinamismo. A análise de Lukács considera possível um retorno ao drama trágico de Schiller, Goethe ou Shakespeare, contrapondo as transformações que o teatro elisabetano ou o romantismo alemão empreenderam na forma da tragédia grega aos ditames do drama burguês. O drama de que nos fala Lukács é a tragédia e para ele tal manifestação artística seria capaz de plasmar as contradições da esfera pública burguesa, já sistematizadas por Kant:

Uma porção de entes racionais, que em conjunto solicitam leis gerais para a sua sobrevivência, das quais cada um secretamente tende, no entanto, a se excetuar: é preciso ordená-los e organizar sua constituição de tal modo que, embora em sua mentalidade privada se contraponham, eles se refreiem reciprocamente de tal modo que, em seu comportamento público, a consequência disso seja como se não tivessem tais intenções maldosas. ${ }^{187}$

Ao público politicamente pensante, para Kant, só proprietários privados é que têm acesso, pois sua autonomia está enraizada na esfera do intercâmbio de mercadorias e,

\footnotetext{
${ }^{186}$ MARX Karl. Sobre a questão judaica. São Paulo: Boitempo, 2010, p. 64.

${ }^{187}$ KANT, Immanuel. A metafisica dos costumes. Bauru, SP: Edipro, 2008, p. 164.
} 
por isso, também coincide com o interesse em sua manutenção como uma esfera privada: "a única qualidade exigida para isso, excetuada a natural, é: que ele seja o seu próprio senhor, tendo portanto alguma propriedade"188. Enquanto os assalariados estão obrigados a trocar a força de trabalho como sua única mercadoria, os proprietários privados se correlacionam como donos de mercadorias através da troca de artigos. Só estes são seus próprios senhores, só eles devem ter o direito de votar e de fazer uso público da razão.

Lukács deposita sua crença na atualidade do drama por acreditar que o indivíduo, o personagem contraditório do drama, ainda é capaz de representar em "seu ser-aí individual" os "traços típicos" da humanidade. Se para Kant o cidadão privado tem acesso à esfera pública através da propriedade, se o uso público da razão está condicionado ao uso privado da mercadoria, para Lukács tal contradição entre esfera pública e privada pode ser expressa através da colisão dramática entre indivíduos típicos:

O ponto decisivo está precisamente na individualidade do herói
dramático. Todos os fatos da vida que encontram seu reflexo
adequado na forma dramática poderão cristalizar de acordo com
suas exigências internas só se as potências em colisão, cujo choque
provoca estes fatos vitais, estão conformadas de tal maneira que
sua luta seja capaz de concentrar-se com uma fisionomia individual
e histórico-social evidente em determinadas personalidades
marcadas. ${ }^{189}$

Salvo engano, o que Lukács não soube perceber é que esta individualidade sob o capitalismo, marcada pela circulação de mercadorias, como já apontava Kant, é tão instável quanto a exposição universal de produtos, que caracteriza a vida danificada sob esta forma de sociabilidade. Podemos pensar como Adorno, para quem a noção de indivíduo não é imutável:

Lukács dificilmente haverá esquecido que Hegel e Marx definiam o indivíduo não como uma categoria natural, mas sim como histórico, quer dizer, só surgido graças ao trabalho (...). Mas se o indivíduo é algo que surge, não há nenhuma ordem do ser que vele para que não volte igualmente a desaparecer.(...) Em Hegel a fase da individuação se chama autoconsciência porque a individualidade não é simplesmente a essência biológica individual, senão sua forma refletida que se mantém como algo particular por meio da razão. Não faltam na grande literatura provas de que em absoluto data só de hoje em dia o questionamento do homem isolado que se

188 Idem,ibd.

${ }^{189}$ LUKÁCS, Georgy. La novela historica. Mexico, D.F.: Ediciones Era, 1966, p. 131. 
determina a si mesmo ${ }^{190}$.

Mesmo no grande ciclo trágico de Schiller, Wallenstein, citado por Lukács como um dos modelos para o drama em que o particular e o universal encontram-se entrelaçados através da colisão dramática, esse declínio do indivíduo está anunciado. A primeira das três partes da obra tem como único espaço cênico a esfera pública: todas as cenas estão situadas em um acampamento de guerra e os personagens comentam a futura chegada e as façanhas pregressas do general protagonista do drama. Podemos logo observar que a própria estrutura da peça, tripartida, com um prólogo que situa a ação publicamente, sem a presença dos personagens centrais, já expõe a dificuldade da forma teatral de que dispunha Schiller em retratar o acontecimento público da guerra. A escolha do tema, a Guerra dos Trinta Anos, parece uma busca por um material histórico que ainda possa ser tratado de forma dramática. No entanto, o olhar do autor, contemporâneo ao início da fetichização do indivíduo e ao fracionamento entre citoyen e bourgeois, o obriga, na tentativa de trazer questões contemporâneas a seu público burguês, a tratar o material antigo de maneira dramática, o que leva, na própria estrutura da obra, a um fracionamento entre as questões públicas da guerra, que são tratadas com recursos épicos, e as questões privadas, tratadas na terceira parte da obra através de recursos dramáticos:

PRIMEIRO CAÇADOR - Fazia-se guerra como que a brincar Com pouca vontade de nela entrar, Ninguém queria estragar amizades, Não se ganhava honra, esta é a verdade. E eu estive quase, por impaciência minha, A voltar para casa para a escrivaninha, Se então o Friedlander, pelas estradas, Não andasse a alistar novas vontades.

SEGUNDO CAÇADOR - E quanto tempo pensais aqui ficar? PRIMEIRO CAÇADOR - Caçoais! Enquanto for ele a mandar,

Alma minha, nem penses em fugir.

Terá o soldado melhor sítio para onde ir? ${ }^{191}$

Toda a primeira parte da peça tem essa estrutura de contemplação, em que os personagens narram as façanhas de seu comandante, sem agir. Assim, parece que

\footnotetext{
${ }^{190}$ ADORNO, Theodor. Carta aberta a Rolf Hochhuth. In: Notas sobre Literatura. Madrid: Akal, 2003, p.572.

${ }^{191}$ SCHILLER, Friedrich. Wallenstein. Porto: Campos das Letras, 2008, p.31.
} 
mesmo um autor contemporâneo ao drama burguês como Schiller precisou negá-lo para conseguir dar forma ao tema da guerra. Em Wallenstein mais do que o indivíduo, os procedimentos épicos são os responsáveis pela cristalização do universo público da narrativa. E a fratura entre parte épica e parte dramática - fratura de ordem distinta da observada em Vianinha, é preciso mencionar, já que em Schiller os universos épico e dramático surgem rigorosamente separados e não justapostos, amontoados - em uma peça escrita de forma partida, algo incomum ao drama, já anuncia o declínio do herói dramático como responsável pela síntese do conteúdo social da obra. Se para Hegel:

A singularidade, individualidade verdadeira, a verdadeira
subjetividade, não é apenas o distanciamento do universal, o
simplesmente determinado, mas sim, enquanto simplesmente
determinado, o ente-para-si, apenas o que se determina a si
próprio. ${ }^{192}$

É possível identificar na teoria sobre o drama de Lukács não só os ecos hegelianos da visão do indivíduo como autodeterminação e autoconsciência mas também uma valoração da forma dramática que percebe na colisão e na contradição características essenciais da própria realidade:

E o embate (Kollision) por cada singular é uma luta pelo todo (...). Isto nenhum deles pode demonstrar ao outro através de palavras, asseguramentos, ameaças ou promessas; pois a linguagem é somente a existência ideal da consciência: mas aqui estão um contra o outro, [seres] efetivos, i.e. [seres] absolutamente contrapostos, absolutamente sendo-para-si(...) Eles têm então de lesar um ao outro. (...) O dano é necessário (...). Cada um tem de afirmar aquilo que foi negado pelo outro como estando em sua totalidade, como algo que não é exterior, suspendendo-o no outro. (...) E somente me torno em verdade reconhecido enquanto racional, enquanto totalidade, ao dirigir-me eu mesmo à morte do outro, ao arriscar minha própria vida e esta extensão de minha existência mesma, ao suspender a totalidade da minha singularidade ${ }^{193}$.

A descrição da realidade como contradição, luta, colisão, exclusão e morte pode ser vista também como a descrição exata das principais características do drama para Lukács. Assim como para Hegel, o indivíduo e herói dramático para o filósofo húngaro só se afirma através do embate com o outro e só se reconhece como singularidade de maneira antagônica. O ágon dos primórdios trágicos é aqui retomado por Lukács para, a

\footnotetext{
${ }^{192}$ HEGEL, G.W.F. Leciones de la historia de la filosofia, III. Ciudad de Mexico: Fondo de Cultura Económica, 1985, p. 287.

${ }^{193}$ HEGEL, G.W.F. Fragmento 22 dos Jenaer Sytementwürfe (1803/1804). Tradução de Erick C. Lima. In: Revista Eletrônica de Estudos Hegelianos, ano 5, n.8, junho de 2008. Consultado em 1/2/2010.
} 
partir de Hegel, caracterizar o drama como forma privilegiada de conhecimento e de expressão da história, já que sua forma seria composta da mesma matéria que compõe o real sob os escombros do capitalismo. O drama seria a forma imediata de síntese artística para a sociabilidade antagônica da mercadoria - a forma do drama, suas idas e vindas, como reprodução exata da esfera da circulação -, possibilitando expor nos seus conflitos individuais e nos seus desenlaces uma forma transparente de apreensão da luta de classes. No entanto, se pensarmos que o indivíduo emerge indissociavelmente ligado a formas de trabalho e de relação com a natureza específicas, e se a colisão - o embate mortal de que nos fala Hegel - de indivíduos capazes de representar tendências históricas universais é a base do drama, é possível pensar também que as transformações sociais que envolvem o trabalho e sua relação com o capital podem deslocar e dissolver a forma dramática.

Para esta pesquisa é indispensável nos perguntarmos sobre as idas e vindas, saltos e retrocessos, trancos e barrancos, deste processo no Brasil. Pensar em como se deu a formação da noção de indivíduo por aqui significa pensar também no processo de recepção e de desenvolvimento do drama entre nós e, como parte integrante do mesmo e contraditório movimento, perceber sua suspensão épica também. Para Francisco de Oliveira:

De acordo com essa literatura dos autores dos anos 30, que criaram a moderna tradição de ciências sociais no Brasil, o indivíduo dotado de razão e capacidade de escolha não se forma na nossa sociedade. E razão aqui não deve ser entendida como incapacidade psicológica, ou falta de capacidade cognitiva. Razão é uma forma social, uma forma de sociabilidade, e deve ser entendida como tal. Essa literatura aponta sempre a ausência da razão socialmente formada, o que ajuda muito a entender os estigmas dessa sociedade, sua desigualdade abissal.(...) Só quando você tem um diálogo entre indivíduos - uma conquista da modernidade - é que a desigualdade aparece como um sinal de dominação de classe. Enquanto isso não ocorre ela fica escondida ou mascarada. Portanto no Brasil não se trata nem de desigualdade. $O$ indivíduo moderno criado pela racionalidade burguesa não foi formado no Brasil. ${ }^{194}$

É possível ler nesta má formação do indivíduo moderno no Brasil a estrutura ornitorrínquica das formas épicas e dramáticas em nosso teatro. Os procedimentos alegóricos estão relacionados a uma "realidade e a uma época alegóricas", à semelhança do drama barroco situado por Benjamin, em que a ausência de indivíduo confere à estrutura e aos movimentos das obras dramáticas e épicas um suceder singular.

\footnotetext{
${ }^{194}$ OLIVEIRA, Francisco. Entrevista à Cia. do Latão. In: Vintém. São Paulo: Hedra, 1999, p. 4.
} 
Pensemos, a este respeito, novamente nos Azeredo mais os Benevides.

Mais do que uma época alegórica, Vianinha soube fixar em sua peça a realidade histórica brasileira como uma contradição insolúvel, formada por opostos sem síntese viável. Parece-nos que a ruína do processo histórico brasileiro não podia ser plasmada sob a forma do teatro épico surgido na Europa, assim como, antes dele, Machado de Assis não pôde utilizar-se apenas da forma pura do romance europeu:

Quando buscava prender as suas fábulas aos pontos de inflexão da história nacional, o romancista seguia a inspiração do realismo europeu, ou, por outra, tentava confeccionar algo semelhante no Brasil. Independência, Abdicação, Regência, Maioridade, Conciliação, Gabinete Rio Branco etc. Seriam os nossos equivalentes da periodização da história francesa pósrevolucionária, cujas etapas, muito nítidas e contrastantes, facultaram aos escritores daquele país uma experiência e uma representação inéditas da historicidade do presente, incluído aí o âmbito privado. (...) Entretanto, apesar das muitas datas, o dinamismo histórico da literatura francesa não existe em sua obra $^{195}$.

O dinamismo histórico apontado por Roberto Schwarz nos autores do realismo europeu não existe na obra de Machado de Assis porque esta expressa a realidade brasileira. A totalidade dialética presente nas grandes parábolas brechtianas, Mãe Coragem e $O$ círculo de giz caucasiano, por exemplo, não está presente na coleção de ruínas da peça de Vianinha talvez porque nosso processo histórico se figurava, no momento em que o dramaturgo escrevia, mais uma vez truncado:

Em 1964, o golpe de força da direita truncou, sem encontrar aliás grande resistência, o vasto processo democrático a que o novo teatro procurava responder. Como é sabido, a repressão ao movimento operário e camponês não teve complacência, ao passo que a censura, destinada a paralisar os estudantes e a intelectualidade de oposição, se provou contornável. Assim, em pouco tempo a esquerda voltava a marcar presença e até a predominar no movimento cultural, só que agora atuando em âmbito socialmente confinado, pautado pela bilheteria e distante dos destinatários populares, que no Período anterior haviam conferido transcendência - em sentido próprio - à sua produção. Por um acaso infeliz, ou melhor, por força da vitória da direita, a nova geração teatral alcançava a plenitude artística (...) no momento em que as condições históricas favoráveis a seu projeto haviam desaparecido. ${ }^{196}$

A petrificação do olhar alegórico de Vianinha expressa um processo histórico que

\footnotetext{
${ }^{195}$ SCHWARZ, Roberto. Posfácio. Contribuição a John Gledson. In: GLEDSON, John. Machado de Assis: ficção e história. São Paulo: Paz e Terra, 2003, p. 324.

${ }^{196}$ SCHWARZ, Roberto. Sequências brasileiras. São Paulo: Cia. Das Letras, 1999, p. 124.
} 
avança retrocedendo, que se move ao transformar-se em pedra. Em Os Azeredo, a fábula não avança, mas é acumulada de detritos. Como obra de bom alegorista, o resultado da peça é que o momento histórico, longe de aparecer como um todo orgânico, aparece em uma disposição arbitrária, como um amontoado desordenado de emblemas, fragmentário e esfacelado. Para Benjamin, a alegoria barroca era a forma de percepção própria de uma época de ruptura social e guerra prolongada, em que o sofrimento humano e a ruína material eram matéria e forma da experiência histórica. $\mathrm{O}$ país que emerge da peça de Vianinha é formado por esta paisagem de exceção permanente.

Bem como os poetas barrocos, o dramaturgo brasileiro, em outro momento histórico, transformou o material desfeito de sua própria época histórica elevando-o à posição de alegoria. O que dava a este ensinamento seu valor como uma apresentação dialética do processo histórico brasileiro foi configurar alegoria e mito de maneira antitética. Na realidade, a alegoria funcionou na peça de Vianinha como o "antídoto" frente ao mito, e precisamente isto é dito por Benjamin: "Deve-se mostrar a alegoria como antídoto contra o mito."197

O mito do "bom povo brasileiro", de uma sociedade "harmônica e feliz" é dissolvido por Vianinha na alegoria da impossível aliança entre classes. Ao ser empregada já na segunda cena da peça, esgarçando a forma épica modelar ao trazer rasgos dramáticos para o seu tecido formal, esta alegoria também esfarela outra mitologia - bastante presente na recepção da obra de Brecht no Brasil -, a do teatro épico como forma absoluta capaz de tratar realisticamente qualquer processo histórico:

\begin{abstract}
Nessas circunstâncias, umas poucas sociedades - talvez se devesse dizer cidades - se dotaram de um teatro político. Tratava-se de um instituto peculiar, que tinha como premissa um movimento popular poderoso, emancipador, capaz de se defender contra os adversários, além de se interessar pelo livre exame de suas questões vitais, com vistas em transições práticas. Para assinalar o incomum dessa criação, Brecht lembra que a maioria das grandes nações não se inclinava a examinar os seus problemas no palco. ${ }^{198}$
\end{abstract}

Como tentativa desse exame, sob forma própria, dos problemas da realidade brasileira no palco, pode-se perceber em Os Azeredo uma certa ausência de resolução ou circularidade: as contradições são petrificadas e expostas como fragmentos sobrepostos, sem que haja a superação do desenvolvimento linear da fábula. Os breves

\footnotetext{
${ }^{197}$ BENJAMIN, Walter . Obras Escolhidas III. São Paulo: Brasiliense, 1989, p. 169.

${ }^{198}$ SCHWARZ, Roberto. Sequências brasileiras. São Paulo: Cia. das Letras, 1999, p. 128.
} 
quadros que se sucedem acumulam imagens e alegorias, principalmente em relação às vitimas do processo capitalista brasileiro, que se organizam ao serem embaralhadas. Ao dissolver o teatro épico na alegoria e no drama, simultaneamente, Vianinha revela a particularidade da formação nacional que, como ruína, não pode ser plasmada por uma forma que concilie suas contradições. A totalidade do teatro épico europeu é recriada e negada na forma da peça como constelação: como imagens saturadas de tensão, advindas de recursos formais contraditórios.

No plano da fábula, ou antifábula, o mito desfeito em Os Azeredo está relacionado à alegoria da superação da luta de classes. A falha trágica de Espiridião é acreditar-se igual aos seus empregados:

(Silêncio. Espiridião pega a foice. Corta.)

ESPIRIDIÃO - Não corta?

ALVIMAR - Não é de assim, doutor... é de assim...

(Espiridião ri. Alvimar ri. Tempo.) ${ }^{199}$

Alvimar, ao acreditar-se igual ao patrão, arruína-se:

Faz oito anos que o doutor Espiridião não vem aqui, Lindaura. Oito anos é um, dois, três, quatro, cinco, seis, sete, oito anos. Me lembro, ele chegou aqui, aí ele pegou na foice errado, de banda, aí a gente riu, eu ria de um lado, doutor ria de outro, aquela gargalheira. Oito anos agora sem notícias? A gente não planta mais cacau faz três anos. Ele prometeu que ia plantar cacau de novo. A vila sumiu, Lindaura, nem trem chega mais. Doutor Espiridião é um interesseiro. É. Digo na cara dele: interesseiro, interesseiro, interesseiro! Dinheiro não faz diferença de ninguém, ouviu, que na honra e na memória estou prá encontrar alguém prá fazer parceria comigo. Interesseiro. Vou ficar plantando só esse arroz amarelo, que nem preço tem, a casa caindo? ${ }^{200}$

Logo após proferir este discurso desconexo e quase louco, Alvimar o repete, palavra por palavra, em uma indicação do dramaturgo de que a cena pode se repetir inúmeras vezes, estabelecendo uma circularidade que poderia dissolver neste instante a ação dramática que, na cena seguinte, é então recomposta. Se retomarmos a fábula de Grusha, no Círculo de giz de Brecht, veremos que o erro da heroína é acreditar que pode ajudar sua patroa, a mulher do governador, adotando o seu filho. A aliança se revela ilusão quando Grusha tem que lutar pelo menino que adotara contra a mãe biológica da criança. Se na Alemanha do pós-guerra a união das classes já surgia como ilusão, fantasma conservador disfarçado de frente liberal, a utilização da ideologia liberal

\footnotetext{
${ }^{199}$ VIANNA, Filho. Os Azeredo mais os Benevides. Rio de Janeiro: MEC/SNC, 1968, p.25.

${ }^{200}$ Ibid., p. 183.
} 
progressista no Brasil, que em seu solo original já surgia como mito, gerara por aqui uma farsa que, de tão extremada, transformara-se no seu negativo. Assim como Alvimar só pode viver na loucura, a sociedade brasileira só funciona como aberração trágica. $\mathrm{O}$ que é mito e pode ser combatido pelo didatismo esclarecido de Brecht nos países centrais, transforma-se em contradição essencial na periferia do capitalismo. O modo de ser da sociedade brasileira é o não ser, situação que a loucura de Alvimar e a caridade de Espiridião alegorizam. Se no modelo europeu a luta pela terra que a história de Grusha procura justificar fora resultado de um processo de lutas e revoluções, no Brasil, a farsa da amizade entre os dois personagens de Os Azeredo alegoriza a construção de um processo histórico que busca dar forma ao vazio. A totalidade de um processo histórico mais transparente é substituída, por aqui, pela catástrofe permanente, catástrofe que a forma da peça, em cacos de materiais épicos e dramáticos colados, expressa.

Se retomarmos a cena II de Os Azeredo citada anteriormente, veremos ainda que a alegoria presente na cena, capaz de universalizar e historicizar a relação pessoal entre os personagens, é justaposta à canção de Lindaura, que traz a cena de volta ao âmbito da relação entre marido e mulher e à amizade entre os dois homens, ao âmbito privado, enfim.

A canção não tem relação necessária com a ação exposta, não servindo de crítica, comentário ou mesmo de complemento narrativo mas tem aqui função dramática, expressando o universo individual dos sentimentos de Lindaura. Esse procedimento das canções, que ao invés de trazerem conteúdo épico reforçam aspectos privativos, pode ser visto também na última cena da peça:

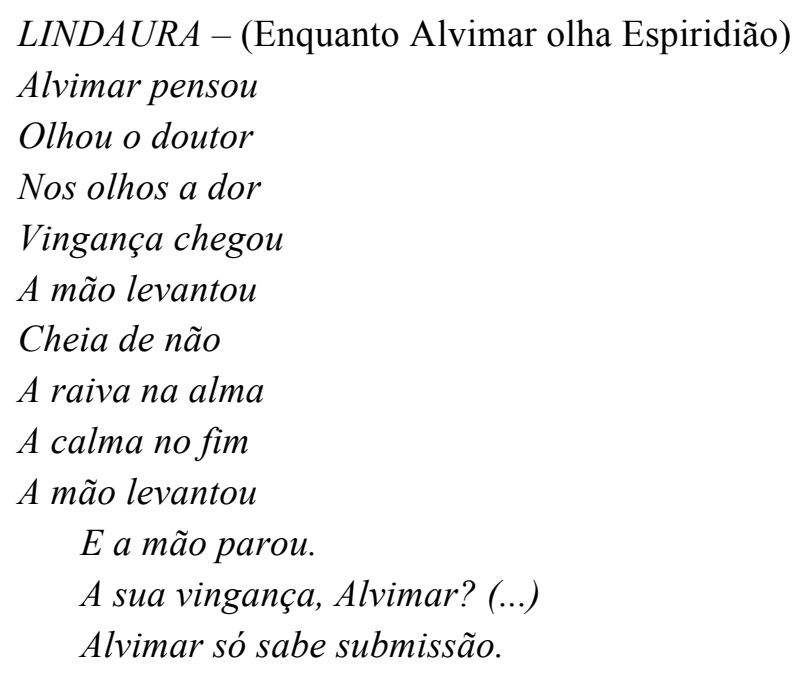


Não aprendeu a dizer não. ${ }^{201}$

Se compararmos esta canção com a canção do Recitante em $O$ círculo de giz, também já analisada acima, perceberemos uma imagem possível para o percurso de transformação da forma teatral épica no Brasil, sintetizado pela peça de Vianinha: como o Recitante, Lindaura narra as ações presentes na cena. No entanto, a frase final do cantor de Brecht é capaz de, através da utilização do recurso do estranhamento, que nega e, ao negar, historiciza os sentimentos privados presentes na cena, relacionar indivíduo e tecido histórico, determinando um ao outro. A diversidade de focos narrativos, que presenciamos em uma única cena do texto de Brecht mas que está presente em toda a peça, também se contrapõe à forma utilizada por Vianinha que, ao privilegiar o foco narrativo único de Alvimar, individualiza as questões, restringindo-as à família do personagem, mesmo que tal narrativa esteja o tempo todo fraturada por conteúdo épico ou pela alegoria central da peça, que reaparece em vários momentos, justapondo-se epicamente à composição dramática do material.

Se, de acordo com Leandro Konder, a tradição filosófica fundamental ao teatro épico, é marcada no Brasil por uma derrota ou um congelamento da dialética, é possível pensar, com relação à recepção do teatro épico por aqui, em uma forma épica não dialética? Como vimos na peça de Vianinha, não se trata exatamente de uma forma que descarta a dialética já que é capaz de, ao reunir materiais formais tão díspares, expor contradições de maneira quase brutal. Em relação ao teatro épico de Brecht, o que está em jogo em Vianinha é uma dialética distinta, ou uma dialética congelada. Caso tal hipótese esteja acertada, podemos pensar que tal derrota da dialética, se é que o seu congelamento pode ser chamado de derrota, significaria não um problema formal mas, como nos romances truncados de Machado de Assis, uma forma própria de plasmar poeticamente nossas agruras e contradições irreconciliáveis.

Se for assim, não estaríamos lidando com uma forma imperfeita de teatro épico mas com uma manifestação do trágico no Brasil: a visão trágica de mundo, com seus paradoxos insuperáveis, marcaria a forma da dialética épica no Brasil, gerando obras estagnadas, afligidas por suas contradições pesadas e imóveis.

Peter Szondi, no seu Teoria do drama moderno, historiciza a forma do drama burguês partindo do seguinte pressuposto: o desenvolvimento do drama no século XX seria marcado por uma crescente contradição entre o enunciado da forma e o enunciado

\footnotetext{
${ }^{201}$ Ibid., p. 106.
} 
do conteúdo, a saber, conteúdos épicos, sedimentados graças a uma situação de complexidade social crescente, seriam cada vez mais objeto dos dramaturgos, o que estabeleceria um choque entre forma dramática, adequada a conflitos subjetivos, e realidade objetiva altamente mediatizada. Deste choque surgiram obras em que a forma dramática aparece cada vez mais dissolvida por conteúdos épicos, até a implosão definitiva do drama burguês, iniciada com o expressionismo, continuada por Brecht, e levada ao limite nos textos do último Beckett, de Koltés ou de Heiner Müller.

Note-se que aqui os conteúdos temáticos, advindos da vida social, não são, por oposição à forma artística, algo informe a que esta daria forma: eles já constituem por seu turno, enunciados, isto é, são formados. Isto quer dizer que não existe um conteúdo vagando nas esferas da abstração estética à espera de uma forma qualquer: cada conteúdo da realidade externa só pode ser apreendido adequadamente sob a forma que ele mesmo exige. Seguindo esta metodologia de análise, que percebe o enunciado da forma em relação de harmonia e conflito com o enunciado do conteúdo, é possível perceber, no desenvolvimento da tragédia clássica grega, o contrário do que Szondi percebe na história do drama burguês: há uma crescente dramatização da forma épica nas tragédias gregas.

Para Hegel:

O verdadeiro poema épico pertence essencialmente a essa época intermédia em que um povo, saído de sua ingenuidade e sentindo o seu espírito despertar, se põe a criar um mundo que lhe seja próprio e no qual se sente à vontade. (...) Quando o eu individual se separou do todo substancial da nação e dos seus estados, das suas maneiras de pensar, das suas ações e destinos e quando, no próprio homem, se efetuou a separação entre vontade e o sentimento, a poesia épica dá lugar à poesia lírica, por um lado, à poesia dramática, por outro. Isto acontece nos últimos dias de vida de um povo, quando já as determinações gerais, que devem presidir aos atos humanos, em vez de fazer parte da totalidade formada pela vida sentimental e mental, assumiram um caráter prosaico, o de uma ordem personificada em instituições políticas, reguladas por prescrições morais e jurídicas fixas que impõem ao homem obrigações e deveres, que ele há de cumprir sob a pressão de uma necessidade exterior, de modo algum imanente. ${ }^{202}$

Em seu Ensaio sobre o trágico, Peter Szondi afirma que Hegel percebeu nas Lições sobre Estética a forma fundamental da tragédia grega: a contradição. A tragédia surge em um momento da vida social ática em que o desenvolvimento da democracia e da expansão comercial e imperial do Estado era determinado pelo surgimento de novas

${ }^{202}$ HEGEL, G. W. F. Curso de estética: o sistema das artes. São Paulo: Martins Fontes, 1997, p. 439. 
instituições, que fracionavam o sujeito, opondo-o aos valores da tradição, marcada pelos deuses, e também aos valores do estado nascente, caracterizado pela emergência de normas opostas à subjetividade e aos princípios comunitários do ingênuo mundo épico. A característica fundamental da tragédia seria assim a dialética.

\begin{abstract}
A ação dramática não se limita a calma e simples progressão para um fim determinado, pelo contrário, decorre essencialmente num meio repleto de conflitos e oposições, porque está sujeita às circunstâncias, paixões e caracteres que se lhe opõem. O drama é produto de uma vida nacional já bastante desenvolvida. ${ }^{203}$
\end{abstract}

Peter Szondi traça um percurso histórico da filosofia do trágico e aponta que já na Poética de Aristóteles, o raciocínio dialético marca a caracterização da tragédia: acontecimentos dolorosos podem ser considerados terríveis e tocantes no mais alto grau quando ocorrem em relações de afeto, "quando por exemplo um irmão mata um irmão ou uma mãe mata o filho..." É o mesmo argumento que, sempre para Szondi, levaria Lessing a passar do efeito para a estrutura dialética do trágico, quando pergunta, na Dramaturgia de Hamburgo: "Por que um poeta não deveria ser livre para intensificar ao máximo nossa compaixão por uma mãe tão delicada, para fazer com que ele se torne infeliz por meio de sua própria ternura?"

O trágico seria assim um modo determinado de aniquilamento iminente ou consumado, justamente o modo dialético. Seria trágico apenas o declínio que ocorre a partir da unidade dos opostos, a partir da transformação de algo em seu oposto, a partir da autodivisão. Mas também só seria trágico o declínio de algo que não pode declinar, algo cujo desaparecimento deixa uma ferida incurável. Pois a contradição trágica não pode ser suprimida em uma esfera de ordem superior, a sua arena é a própria história, a história de um mundo que nasce entre os escombros do mundo harmônico da epopeia.

\title{
AQUILES: \\ Assim falou a águia, ao perceber as penas \\ $\mathrm{Na}$ flecha que a perfurava: \\ Então somos abatidas \\ Por nossas próprias asas. (ÉSQUILO) ${ }^{204}$
}

Estaríamos, na tradição épica do teatro brasileiro, representada aqui pela peça de Vianinha, diante de um épico não dialético mas trágico, ou de uma dialética específica, a do trágico, de uma dialética à brasileira, marcada por realidades, teatrais $\mathrm{e}$

\footnotetext{
${ }^{203}$ Idem, p. 442.

204 SZONDI, Peter. Ensaio sobre o trágico. Rio de Janeiro: Jorge Zahar, 2004, p. 88.
} 
econômicas, que são e não são. Se esta hipótese estiver certa, a má formação brasileira teria gerado um gênero híbrido, em que o épico justapõe-se ao trágico e ao dramático, na dialética de aniquilamento do que não pode desaparecer, típica da forma trágica e de uma formação social que se tornou capitalista por meio da escravidão, ou que conjuga contradições inéditas e brutais. Como falar de um país que é e não é capitalista, ao mesmo tempo, senão através de uma forma que não fosse e fosse épica, simultaneamente? Uma forma que fosse e não fosse trágica, ao mesmo tempo? A estrutura desta forma é marcada por uma permanente dualidade: drama e épico, protagonista e antagonista, coletivo e indivíduo, sujeito e objeto, norma e infração, símbolo e alegoria, personagem e figura, público e privado, lirismo e discurso, o que pode ser identificado na obra de um dramaturgo como Vianinha, autor de peças em que tais oposições encontram-se traduzidas em formas acumuladas e paralisadas, ao invés de estarem em movimento de recíproca autoconversão (como no teatro épico de Brecht, por exemplo, ou na tragédia clássica).

Se não estivermos errados, a dialética trágica presente na forma épica de $O s$ Azeredo mais os Benevides expressaria, em sua justaposição de extremos dramáticos e épicos, públicos e privados, uma forma bem específica de sentimento dos contrários, presente na sociedade brasileira, e que tem como mediação a malandragem, o favor e a cordialidade, mediações capazes de, como a forma da peça, conjugar contradições congelando-as.

\section{2. Novo olhar melancólico: dialética brasileira no épico arruinado de} Miopia

Em Miopia, o estudo da dialética e o mergulho no processo histórico capitalista brasileiro, dos anos 30 e dos anos 2000, através da pesquisa teórica e da ocupação do espaço em ruínas da Usina, gerou uma tentativa de resposta ao impasse da dialética truncada e trágica do teatro épico brasileiro: ao contrário das transformações sofridas pelo teatro contemporâneo dos países centrais, Miopia, criada na periferia da periferia capitalista, afastou-se também dos padrões chamados mais recentemente de pósdramáticos, assim como décadas atrás Vianinha se afastara dos padrões do teatro épico europeu do pós-guerra. Tal afastamento respondeu à tragédia da dialética brasileira por meio de uma explosão da forma épica dual, marcada por pares binários de oposições acirradas, em um movimento de múltiplas contradições. As estruturas do épico, 
diálogos, narrativa, conflitos, foram implodidas por inúmeras contradições que, de tão numerosas, levaram à erosão e ao esfacelamento da forma épica, gerando uma encenação em que miríades de alegorias sedimentavam múltiplas camadas de sentido ao tecido da peça. Esta construção de ruínas não se deu como crítica consciente aos procedimentos do teatro épico mas, parodoxalmente, foi gerada dentro de um processo de investigação que visava a aproximação da forma épica tradicional.

Esta dialética do trágico e do épico que identificamos em Vianinha esteve presente também em Miopia, mas por outros labirintos. O estudo dos heróis trágicos durante a criação do espetáculo partiu de sua essência contraditória, material fundamental para um processo criativo que queria, através de personagens cindidos, revelar as contradições do real.

Decidimos partir de um estudo de dramaturgia, para tentar dar maior profundidade às cenas improvisadas. Percebemos que os personagens surgem sempre frágeis psicologicamente. Decidimos então mergulhar no estudo dos heróis trágicos, que já começara na montagem do Coriolanos. ${ }^{205}$

Os heróis trágicos surgem, como podemos observar a partir do relato de uma das atrizes, a partir de uma intenção de dar feição psicológica aos personagens. Esse paradigma, presente na pesquisa graças aos estudos de Stanislavski, revela o quanto o grupo esteve preso, durante o trabalho de criação, a referências formais que demoraram a ser problematizadas. Assim, o processo de criação dos personagens baseou-se em sua fase inicial em uma contradição: o confronto entre o universo clássico, vindo dos textos gregos, e o universo contemporâneo, vindo dos relatos e experiências dos atores e dos participantes das oficinas ministradas na Usina de lixo. Este confronto, entre um tempo histórico extinto e uma sociedade altamente mediatizada e fracionada por novas relações de trabalho e de exclusão, pôde revelar, por contraste, aspectos do real obscurecidos por uma experiência cotidiana anestesiada.

No início do processo de criação, os heróis trágicos interessaram por suas trajetórias contraditórias, base fundamental para um grupo interessado em produzir um teatro dialético. Aos poucos, o estudo dos heróis nos revelou sujeitos portadores de

\footnotetext{
${ }^{205}$ PEIXOTO, Elenira. Construção de Rosa Medeiros. In: ALMEIDA, Ligia Marina; FARIA, Fernanda; DELMANTO, Ivan, et al. Anjos do desespero. Relatório da segunda etapa de pesquisa. Apresentado à Secretaria de Cultura do Município de São Paulo. Inédito, 2006, p. 67. Disponível para consulta na Divisão de Fomento da Secretaria Municipal de Cultura.
} 
valores absolutos, muito distintos do divíduo contemporâneo, que cada vez mais perde a noção de si mesmo para a colonização do consumo. Os heróis tornaram-se, então, modelo de uma subjetividade já extinta: material para ser negado, contraposto pelo personagem quase esquizo do capitalismo mundializado.

Com o aprofundamento da pesquisa, o grupo percebeu que mais do que o herói, o que interessava era o conceito de tragicidade, ou seja, a dissolução, a dissonância, a destruição do herói que é característica do gênero trágico. Considerou-se que a dimensão trágica do herói vem-lhe da fraqueza da sua condição, apesar do vigor tradicional; da derrota que é a morte ou a loucura de alguém que foi um dia um vencedor. Os personagens passaram a ser criados então vislumbrando o herói trágico como um modelo de personalidade agônica, em vias de aniquilamento, neste sentido muito próximo do sujeito-consumidor de hoje, habitado, em dissolução contínua, pelas vozes furiosas da mercadoria. O conceito de subjetividade estaria próximo de:

Esta é também uma das maneiras de explicar o sentido da asserção lacaniana do "descentramento" constitutivo do sujeito. Seu argumento não é que minha experiência subjetiva está regulada por mecanismos inconscientes objetivos que estão descentrados em relação com minha autoexperiência e, como tais, fora do meu controle; senão que é algo muito mais inquietante, a saber, que estou privado inclusive de minha mais íntima experiência "subjetiva", a do fantasma fundamental que constitui e garante o centro de meu ser, posto que não me é possível experimentá-lo e assumi-lo nunca. ${ }^{206}$

Para Zizek, seguindo pistas de Lacan, a concepção usual da subjetividade é da (auto) experiência fenomênica: "sou um sujeito desde o momento que posso dizer-me a mim mesmo: não importa que mecanismos desconhecidos governem meus atos, percepções e pensamentos; ninguém pode tirar-me o que vejo e o que sinto agora". O argumento de Lacan seria que o psicanalista é aquele que, precisamente, pode acabar com esta ilusão, que tem como objetivo último privar o sujeito de seu próprio fantasma fundamental que regula o universo de sua (auto) experiência. O sujeito do Inconsciente freudiano surgiria somente quando um aspecto capital da (auto) experiência fenomênica do sujeito, seu fantasma fundamental, se torna inacessível, isto é, "primordialmente reprimido". No que tem de mais radical, o Inconsciente é o fenômeno inacessível, não o mecanismo que regula a experiência cotidiana. É esta inacessibilidade que converte o sujeito em vazio. Em outras palavras, nos é permitido assim formular uma

${ }^{206}$ ZIZEK, Slavoj. Órganos sin cuerpo. Valencia: Pre-textos, 2006, p. 116. 
fenomenologia sem sujeito: aparecem fenômenos que não são fenômenos de um sujeito, que não aparecem (auto) conscientes a este sujeito. Isto não quer dizer, ao contrário do que afirmam alguns ideologemas pós-modernos, que o sujeito está morto. O sujeito, para Zizek, está presente, mas na forma de exclusão, como instância negativa que não é capaz de assumir tais fenômenos.

É possível imaginar a transformação que tal concepção de subjetividade pode causar na estética teatral narrativa e, principalmente, no trabalho com o seu ator. Sob tal estética, a célula da criação do personagem pelo ator sempre foi a ação, gerada por objetivos conscientemente formulados pelo personagem. Caberia ao ator também esclarecer com precisão as zonas cinzentas que baseiam as atitudes de cada personagem, tornando consciente para o ator aquilo que é inconsciente para o personagem. A noção de superobjetivo, que estruturou a composição do personagem para Stanislavski e para o Brecht maduro do teatro dialético é tributária desta concepção de ator reflexivo e onisciente. Mas como fica o trabalho do ator para uma concepção de sujeito que envolve o fantasma? O fantasma é, por definição, não-objetivo, no sentido mais simples de "existir independentemente das percepções do sujeito". Mas, por outro lado, é também não-subjetivo, no sentido de ser reduzido às intuições conscientemente experimentadas pelo sujeito. O fantasma seria para o trabalho do ator uma categoria essencialmente negativa, o que há de inacessível e de vazio no personagem. Para uma composição de personagem baseada neste princípio, caberia ao ator formular o que o personagem é incapaz de identificar, ou por outra, formular o vazio.

No entanto, na sua prática de ensaio, a composição dos personagens em Miopia não seguiu este caminho. Categorias como objetivo, superobjetivo e distanciamento foram experimentadas durante a maior parte do processo e basearam a construção dos personagens por parte dos atores. Durante o processo de criação, o grupo considerou todos os heróis trágicos como condenados ao aniquilamento, ao exílio da realidade, à desterritorialização permanente, à deriva, ao emudecimento, à dilaceração dos desejos que não podem controlar e que os controlam. Enfim, todos estes heróis aniquilados foram considerados insanos, ou como diria Foucault, habitantes da desrazão. Nenhum deles pode habitar a si mesmo. Por isso as vozes do espetáculo e da forma mercadoria deveriam tomá-los, consumi-los, em uma mímesis do exército de consumidores contemporâneos. Este aniquilamento, este habitar na fronteira instável da desrazão, foi plasmado, no entanto, com metodologias tradicionais de trabalho de ator: 
1/2/2006 - Ensaio da cena do pátio das torturas. Estefânia com muitas dificuldades para fazer o Antenor torturador. Caímos sempre no vilão. Após algumas crises, experimentamos fazer a cena inúmeras vezes, a cada uma com um único objetivo: arranhar a cara de Fausto, acariciar as máquinas, tirar a roupa, vestir-se, tirar a máscara de ferro de uma das vítimas, comer, fugir, gritar. Os verbos menos genéricos se mostraram mais produtivos. Depois de tudo, compusemos uma partitura de ações definindo um objetivo para cada unidade da cena. Resolvemos a cena. ${ }^{207}$

A cena foi considerada "resolvida" quando um exercício de clara inspiração stanislavskiana foi experimentado. Entretanto, cabe-nos perguntar como a encenação da peça pôde ser construída a partir de diversas manifestações fantasmáticas, em um resultado cênico que em nenhum momento exibia com clareza a narrativa, os personagens e, menos ainda, os motores de suas ações que, de resto, em seu caráter alegórico, não podiam ser compreendidas sob a moldura realista. Talvez a resposta esteja na contradição entre texto e cena, aspecto a que nos deteremos mais a frente mas que podemos adiantar na constatação de que o texto foi construído sob determinados parâmetros (narrativa, personagem), que os personagens foram construídos, até determinada etapa do processo, a partir dos mesmos parâmetros (as referências de Brecht e de Stanislavski, principalmente) mas que na fase final da construção da peça a encenação ganhou formas absolutamente distintas, em negação aos princípios advindos do texto. Esta negação empreendida pela cena seria responsável pelos aspectos fantasmáticos que impregnaram o labirinto de Miopia.

É possível perceber com mais profundidade este tecido formal dilacerado por contradições múltiplas e fantasmas se olharmos para a seguinte cena da peça:

\section{MARCO INICIAL DA CIDADE \\ Trabalhadores do Circo com estacas e cordas na mão. Enfileirados atrás de uma faixa: PARTIDA PARA O SONHO. \\ BELMIRO - (Ao lado do Autômato Turco.) Companheiros: vamos de vitória a vitória e de triunfo em triunfo! Antes de iniciarmos as celebrações, eu gostaria de propor um viva aos operários do mundo! Hoje, no ano de 1932, comemoramos o aniversário de quinze anos da Revolução Soviética! Viva! (Silêncio total.)Viva! Não sejam tímidos, camaradas! Os comunistas só querem paz, pão e terra! (Silêncio.) \\ VOZ TÍMIDA - Terra!}

FAUSTO - Nós não somos mais comunistas! Nós não somos mais fascistas! Nós não somos mais liberais! Nossa pátria é o desterro, o exílio, o deserto! (Aplausos entusiasmados.) Não queremos saber dos políticos tradicionais! (Aplausos entusiasmados.) Só queremos ter onde morar e onde criar nossos filhos! (Aplausos

${ }^{207}$ DELMANTO, Ivan. Caderno de direção - 2006. Inédito, 2006, p. 13. 
entusiasmados.) Por isto aqui estamos para fundar uma nova cidade! (Aplausos entusiasmados.)

ROSA - Antes de iniciar as comemorações é preciso homenagear o Turco Fuad Chucro, falecido há exatos dois anos. Com muita generosidade, o senhor Chucro nos empregou a todos no Circo dos Autômatos, aceitando a ideia de formar a primeira cooperativa socialista de trabalhadores do Brasil!(Aplausos.)

BELMIRO - Fuad Chucro nos deixou também o Autômato Turco, nosso guia e padroeiro. (Aplausos enlouquecidos.) Ele tem uma palavra de sabedoria a nos dizer.

AUTÔMATO TURCO - A palavra de hoje é: dinheiro. (Aplausos enlouquecidos. Faixas com os dizeres: "Obrigado por tudo, Autômato Turco" são exibidas. Pessoas vestem camisetas do autômato.)

ROSA - Perfeito. Com o dinheiro da nossa cooperativa vamos construir a nossa cidade, camaradas! Chega de ser explorados! Chega de injustiça! Vamos criar nossa própria vida e nossa própria lei! Estas terras estão abandonadas! Por isto, os trabalhadores da Cooperativa do Circo dos Autômatos decretam: esta terra é nossa!

FAUSTO - É tudo nosso, meu povo! (Aplausos entusiasmados.)

ROSA - Um momento, um momento, por favor. Para que haja o máximo de justiça possível, nós da liderança queremos votar duas propostas. Já decidimos que o lote de terra de cada um será igual aqui! Mas para escolher onde fica o lote de terra de cada um...

TRABALHADOR 1 - Eu não quero lote em barranco!

TRABALHADOR 2 - Eu quero perto do rio!

TRABALHADOR 3 - Eu quero perto do rio!

ROSA - A primeira proposta é: de forma solidária, cada um escolhe o pedaço de terra que quiser. Para resolver os casos de disputa, usaremos os seguintes critérios: 1. Maior número de filhos. 2. Doença na família. 3. Sorteio.

FAUSTO - Esta é a primeira proposta da direção. Eu vou apresentar a segunda: o critério não é a solidariedade, critério subjetivo e discutível. O critério para definir o pedaço de terra de cada um é o mérito! Quem tiver mais mérito fica com a terra!

ROSA - Questão de ordem! Mérito também é um critério discutível, companheiro Fausto!

FAUSTO - Questão de mérito, de competência! Com sua estaca na mão, todas as famílias se reúnem atrás da faixa de partida. Quando ouvirem o disparo é dada a largada. Quem for mais rápido e inteligente, chega primeiro ao seu lote de terra e faz a demarcação! Quem chegar depois respeita o mérito do mais rápido! (Aplausos entusiasmados.)

ROSA - Essa é a lei das selvas!

FAUSTO - É a lei dos justos. Vamos votar. Quem é a favor da proposta 1 levante os braços. (Um aleijado levanta a mão.) Certo. Quem é a favor da proposta 2 levante os braços! (Todos levantam.) Vitória da proposta 2! (Aplausos entusiasmados.)

ROSA - Eu não aceito.

FAUSTO - Está com medo? Participe da corrida.

ROSA - Eu exijo que você também participe.

FAUSTO - Calma, senhora. Está bem, eu não tenho medo de 
concorrência.

ROSA - Você não vem, Belmiro?

BELMIRO - Eu vou fícar protegendo o Autômato Turco. Eu confio em você na corrida por nós, Rosa.

FAUSTO - Então ele dará a largada. (Fausto entrega a pistola a Belmiro. Todos estão perfilados. É dada a largada. Inicia-se uma onda de selvageria. Os mais fortes conseguem pegar os melhores lotes. Fausto é o mais violento e pega o lote central, derrubando vários concorrentes. Todos desabam ao final, exaustos. Belmiro e o Autômato se levantam e entregam dois sacos de dinheiro para dois homens).

HOMEM 1 - Posso contar? É aquilo mesmo?

AUTÔMATO - Aqui tem metade do que nós guardamos. Anos e anos perambulando por florestas, pântanos, vilas, pocilgas, pulgueiros, presídios, prostíbulos, verminoses e esterco humano. $\mathrm{O}$ sacrifício nos legou privilégios.

HOMEM 2 - (Pegando o outro saco de dinheiro.) Eu nunca mais volto aqui. (Os dois saem. Belmiro junta os dois lotes em um só. Escreve o seu nome no chão. Senta-se ao lado do Autômato Turco.) AUTÔMATO - Muito bem, Belmiro. Este agora é o nosso lote! ${ }^{208}$

A cena tem como tema a propriedade da terra, mesmo conteúdo das cenas de Brecht e de Vianinha citadas anteriormente. Se atentarmos apenas para a organização formal do texto, perceberemos uma estrutura muito próxima aos parâmetros clássicos do teatro épico: o conflito gravita em torno de uma questão pública, que não envolve a sentimentalidade do drama burguês, a ação central tem um claro sentido alegórico (como a disputa pelo filho que em Brecht representa a disputa pela terra), a saber, a demarcação da propriedade privada alegoriza a história do capitalismo, sendo realizada primeiramente através da força e depois por meio da troca, quando a terra torna-se mercadoria; a cena tem um sentido em si mesma, não dependendo da unidade e do encadeamento de ações anteriores, previstos no drama burguês; a cena tem elementos narrativos, que interpelam o público e o transformam em participante do comício inicial.

No entanto, se considerarmos a encenação, veremos que novas tensões são adicionadas à dramaturgia textual, explodindo os sentidos literários iniciais em novas contradições, gerando um acúmulo de ruínas que pode ser lido em outros sentidos, gerando fantasmas de difícil nomeação mas passíveis de identificação como zonas de obscuridade.

A cena foi construída a partir de um exercício praticado pelos atores como

${ }^{208}$ ALMEIDA, Ligia Marina; DELMANTO, Ivan; FARIA, Fernanda, et al. Miopia. Inédito, 2006, p.7-8. 
aquecimento e treinamento físico: manipulando um bastão, como se este fosse uma extensão do próprio corpo, cada ator deveria buscar ações a partir da imagem de um guerreiro. Esta imagem poderia ser a mais diversificada: desde um soldado na Guerra do Iraque até um samurai japonês. Após alguns dias de trabalho com os bastões, os atores elaboraram partituras físicas, sequências de ações a partir do que havia surgido de mais marcante na prática de cada um. A situação da chegada de trabalhadores a um local deserto no Mato Grosso foi então improvisada, utilizando apenas a partitura física de cada ator. Como os atores não podiam recorrer a ações e movimentos cotidianos, a cena teve, forçosamente, diversas versões, todas elas de sentido obscuro. Decidimos então por elaborar uma partitura física conjunta, que simulasse um combate pela terra, combate que nos pareceu ser o tema comum (e abstrato) que unia todo o material que tínhamos improvisado para a cena até aquele momento. Decidimos por um combate em que todos os trabalhadores agissem da mesma forma, ou seja, em que todos os atores seguissem a mesma partitura de ação. Assim, quando eu trouxe uma proposta de texto, já sabíamos que a cena teria um combate sem vencedores e vilões, em que haveria um comportamento padronizado e administrado por parte de todos os trabalhadores, que desmentiria todo o discurso utópico do texto. O combate com os bastões também não era explicitamente uma colisão: como as ações surgiram em um contexto anterior à criação do texto, as partituras dos atores remetiam a um combate, mas também poderiam ser lidas como uma dança.

$\mathrm{O}$ texto de Belmiro e de Fausto foi então trabalhado para que fosse dito pelos atores como se a corrida pela terra fosse um show. O resultado era o anúncio inicial de um discurso de igualdade. Tal discurso era seguido do anúncio de uma corrida pela terra, que terminava com um combate. $\mathrm{O}$ acúmulo de sentidos: comício eivado de palavras pertencentes à tradição stalinista, corrida pela terra, dança e combate sangrento uniam, no plano da encenação, temas distintos como sociedade do espetáculo, teoria política, lazer e trabalho. A mediação universal entre todos os termos é a forma mercadoria, representada pela compra da terra que, no fim de tudo, é o que decide quem serão os donos do poder, neste caso Belmiro, sobrepondo-se à violência explícita de Fausto, o personagem fascista.

Esta é a dramaturgia da encenação que pode ser lida, em confronto com o texto, citado acima. Mas talvez seja interessante nos determos no que permanece reprimido na cena, naquilo que não podia ser lido. A sequência de ações acima, apesar de múltipla, de agregar imagens distintas em uma colagem, pode ser compreendida se considerarmos 
as intenções de cada personagem: a luta sangrenta pela terra, por parte de miseráveis, e a manipulação deste processo por parte das lideranças, utilizando procedimentos espetaculares, é facilmente legível, por mais que os recursos cênicos empregados fossem de caráter alegórico e não cotidiano.

Mas podemos identificar na cena deslizamentos, ruídos, desmoronamentos. Nesta cena, estes trânsitos de obscuridade talvez gravitem em torno da figura do Autômato Turco. O autômato não era encenado como um boneco: era apenas uma cabeça, com uma boca articulada, à maneira dos bonecos de ventríloco, mas confeccionada com jornal, inacabada, que era empunhada pelo ator que representava Belmiro por meio de um pedaço de cabo de vassoura, que parecia simular um pescoço. A cada frase do Autômato, Belmiro (ou ator que representava Belmiro, isto não se esclarecia na cena) manipulava a boca da cabeça, dizendo o texto do boneco com uma voz aguda, de difícil compreensão. Aqui a primeira zona de ilegibilidade: se é o ator que manipula o boneco, este último tem existência independente no espaço da narrativa. Se é Belmiro - o personagem - que manipula o Autômato, não há nenhum boneco idolatrado e quem dita as ordens na cena é Belmiro travestido de boneco. Esta ambiguidade estruturava a cena: ora parecia que todos obedeciam aos comandos de uma voz intangível, ora parecia que eram todos conduzidos por Belmiro. Como o boneco era manipulado às claras, sem nenhuma espécie de subterfúgio, a impressão era que todos escolhiam ser manietados conscientemente, quase que em um jogo infantil e cruel.

Assim, a cada ação coletiva havia o estímulo, a ordem, dada pelo Autômato. E durante a execução de cada instrução, Belmiro e o boneco percorriam o espaço cênico, como se fiscalizassem as atividades. Os demais personagens relacionavam-se o tempo todo com o Autômato, mais do que com o público, como se o boneco fosse o público a que se destinava cada ação executada e cada palavra proferida. Público imaginário ou imaginado, talvez, já que na cena seguinte Belmiro surge, já como um importante empresário, sem o boneco, que desaparece do restante da peça, sem nenhuma explicação, além da absurda: "o boneco faleceu". O Autômato Turco existiu de fato? Ou este fantasma, móvel dos desejos e ações de todos durante a construção da cidade, nunca foi real? A encenação, ao criar imagens e compor ações sem propósito claro, compunha estes fantasmas, estes vazios de significado capazes de mover a engrenagem da cena que, de resto, surgia geralmente como mecanismo obscuro. O lema de Brecht, de uma composição cênica que pudesse revelar suas engrenagens, surge aqui em negativo: a encenação revela, no lugar dos seus motores, seus fantasmas, que, 
alegoricamente, podem assumir também a máscara de fantasmas das subjetividades dos personagens e do próprio público, geralmente cúmplice das ações representadas sem possibilidade de escolha.

Essa ausência da real possibilidade de escolha (em contraste com o suposto papel de interatividade a que o público era constantemente convocado a assumir), após repetida inúmeras vezes assumia, neste momento da peça, a faceta alegórica do Inferno. Vimos anteriormente que Walter Benjamin caracterizou a modernidade como infernal em sua "sociabilidade da repetição", baseada sob os ditames da forma mercadoria. A encenação de Miopia inspirou-se nesta alegoria do inferno sob dois aspectos: primeiro com relação à repetição de procedimentos; as imagens constantemente refeitas (como as que remetiam ao lixo) e a relação cínica com o público são dois dos exemplos mais frequentes. Em segundo lugar, o próprio percurso do público, que seguia o trajeto do lixo quando este era triturado e "compostado", do plano mais alto do espaço da Usina até o mais baixo, em uma descida por escadarias estreitas que procurava alegorizar uma descida aos ínferos. No caso desta cena de inauguração da cidade, a pintura vermelha que recobria todo o salão amplo da Usina, paredes, teto e piso com uma cor vibrante, interrompida por pichações e grafitagens que há muito já faziam parte do local, gerava um ambiente infernal em sua hipertrofiada poluição visual. Era como se a cidade fosse inaugurada no inferno, sala habitada por enormes máquinas desativadas, em que o lixo havia se incorporado às paredes, ao chão e ao teto. A incorporação do lixo, veremos, também contaminou e produziu as dramaturgias da cena.

Mais do que isso, algumas ações da cena foram propostas em improvisações realizadas pelos atores a partir de fragmentos do Inferno, de Dante. A improvisação escolhida, realizada por Marcus e Elenira dialogava com:

Canto XXXII do "Inferno". Eu queria falar da possibilidade de utopia hoje, o grande tema da peça para mim. Propusemos então uma improvisação sobre o texto. Rosa Medeiros assistia muda o Autômato Turco devorar o crânio de Belmiro. Depois, Belmiro devorava o crânio do boneco, e assim sucessivamente, em uma repetição infinita. Demoramos mais de 20 minutos repetindo as mesmas ações. ${ }^{209}$

O canto XXXII do Inferno, que pautou a improvisação narrada por Elenira diz

209 PEIXOTO, Elenira. "Diário de trabalho". In: ALMEIDA, Ligia Marina; FARIA, Fernanda; DELMANTO, Ivan, et al. Anjos do desespero. Relatório da segunda etapa de pesquisa. Apresentado à Secretaria de Cultura do Município de São Paulo. Inédito, 2006, p, 254. Disponível para consulta na Divisão de Fomento da Secretaria Municipal de Cultura. 
respeito ao nono e último círculo infernal, o dos traidores, em que Dante encontra o espírito do conde Ugolino, condenado a roer eternamente a cabeça de um outro:
Afastando-me então desse libelo,
Dois juntos vi num fosso: parecia
De uma a outra cabeça ser capelo;
E como um pão morde-se na agonia
Da fome, um no outro seus dentes meteu
Onde o crânio da nuca se inicia. ${ }^{210}$

Chama atenção a revelação de que a cena proposta, em seu caráter infernal, representado pela eterna repetição do devoramento mútuo entre Belmiro e o Autômato, fora criada para expressar "o grande tema da peça, a possibilidade de utopia". O devoramento, pelo contrário, expressava a impossibilidade da utopia. A ação proposta por Elenira foi incorporada à versão final da cena, que tinha como última imagem a ação de Belmiro mordendo o crânio do boneco que, instantes depois, era manipulado e devolvia a mordida, por sua vez, no crânio de Belmiro. A ação ocorria repetidamente, enquanto o público deslocava-se para fora do salão vermelho, rumo à cena seguinte. Quando já estavam longe, gritos forçavam o espectador a olhar para trás e ver outros personagens da cena, Rosa, Fausto e demais trabalhadores, também devorando cabeças de bonecos. Se eram bonecos, como o Autômato, ou cadáveres, a cena não expressava ao certo. A repetição, por parte dos demais personagens da cena, da ação realizada por Belmiro e seu boneco, além de reforçar o caráter fantasmático que parecia dirigir os desejos dos fundadores da cidade, transformava o caráter utópico dos discursos sobre a fundação de Miopia no seu negativo infernal.

Este procedimento de conversão de uma cidade utópica em mundo infernal não é novo e pode ser encontrado na tradição do teatro épico, de forma emblemática, na peça de Brecht Ascensão e queda da cidade de Mahagonny. Para Adorno, Mahagonny teria sido construída sob o ponto de vista onírico da imaginação infantil, "a visão de soslaio infantil, que se nutre de livros de índios e histórias de navegantes, converte-se em meio de desencantamento da ordem capitalista, cujos pátios se transformam em planícies do Colorado, suas crises em furacões, seu aparato de poder em revólveres carregados" 211 . Este processo de desencantamento do potencial utópico prometido pela ordem capitalista pode ser visto na peça de Brecht também na cena de fundação da

\footnotetext{
${ }^{210}$ ALIGHIERI, Dante. A divina comédia: Inferno. São Paulo: Ed. 34, 1998, p. 215.

${ }^{211}$ ADORNO, Theodor. "Mahagonny”. In: Escritos musicales IV. Madrid: Akal, 2004, p. 126.
} 
cidade, desta vez chamada de Mahagonny e não de Miopia. No momento da fundação, a poderosa paródia do contrato social e da construção do Estado, a alcoviteira Leokadja Begbick profere sua maldição infernal: "Mas toda esta Mahagonny só existe porque tudo é tão mau, porque não reina nenhuma paz nem concórdia, e porque não há nada ao que alguém se possa ater".

Em Mahagonny o teatro épico serve à intenção de substituir a cerrada totalidade do drama burguês pela fragmentária justaposição de seus escombros, de, nos espaços vazios entre os escombros, tomar posse do conto de fadas imanente, de destruí-lo desde esta proximidade e inclusive graças à paixão infantil do olhar épico. A forma que descreve e critica uma realidade desregrada não pode ela mesma tomar a aparência de uma totalidade. Esta composição de escombros, no entanto, distancia-se das ruínas acumuladas em Miopia. Talvez possamos compreender esta diferença se recorrermos à caracterização de Guernica, empreendida por Peter Weiss, na já citada Estética da resistência.

Peter Weiss sempre pensou no Inferno de Dante como uma imagem de seu tempo. Em 26 de abril de 1937 as bombas incendiárias arrojadas pelos aviões alemãs da Legião Condor arrasaram Guernica. Ayschmann e Hodann, os jovens trabalhadores alemães comunistas que haviam abandonado a Alemanha para combater na Espanha pela causa republicana, surgem na narrativa de Weiss deslumbrados diante de Guernica - como antes estiveram fascinados seus amigos Coppi e Heilmann em Berlim, diante do Altar de Pérgamo e ante a Sagrada Família. Os jovens trabalhadores, com uma escassa formação autodidata, descobrem pouco a pouco, durante a contemplação de Guernica, a história da arte como a história da vida humana em que podem decifrar as diferentes etapas das grandes decisões políticas e sociais:

\begin{abstract}
Sem compreender de todo, vimos o que ocorria na Espanha. Relatado em uma linguagem de poucos signos, a pintura continha ao mesmo tempo destruição e renovação, desespero e esperança. Os corpos estavam nus, golpeados e deformados (...). Das chamas se alçavam braços, os corpos estirando-se, os traços do rosto contraindo-se pelo horror, o corpo reduzido a uma perna, carbonizado e atirado acima pelo calor do forno ardendo. ${ }^{212}$
\end{abstract}

Na leitura de Peter Weiss sobre o quadro de Picasso estão sintetizados alguns pontos de vista presentes na Estética da resistência e também em parte da obra de Bertolt Brecht sobre a função da arte. Guernica é apresentada no romance como uma

${ }^{212}$ WEISS, Peter. Op.cit.,p. 321. 
obra que não exporia uma estética do horror ou da deformidade, mas sim apresentaria a dialética entre o desespero e a esperança. Neste sentido, para Weiss, "a lâmpada de azeite de Guernica é a luz da consciência e do conhecimento". A informação histórica, a estruturação do pensamento como uma das condições para chegar a conhecer, e a união entre as emoções e a própria experiência prática seriam o marco capaz de conformar uma estética da resistência contra todo poder imposto. Os protagonistas do romance não entendem Guernica como um instrumento de agitação política, mas sim como um motivo para examinar o quadro desde diferentes ângulos, procurando compreendê-lo em sua totalidade, percorrendo as relações possíveis entre o geral e o particular. Na contemplação da obra de arte surgiria uma espécie de "impaciência do pensamento" e disso a necessidade do espectador de investigar e de refletir de forma concreta. Esta missão cognitiva da arte está explicitada em grande parte da teoria teatral de Brecht:

Todo e qualquer processo entre homens que se desenrola numa esquina de rua real é "verdadeiro" e ao mesmo tempo incompreensível. Como na imitação no teatro, o espectador vê aqui (...) a sua causa imediata. Mas como todos sabemos hoje em dia, as causas existem em séries, tendo elas próprias as suas causas, e o processo na esquina da rua e a sua imitação "verídica" no teatro têm ambos uma série de causas muito curta, apreensível, o nexo causal é pobre, primitivo, no teatro ainda consideravelmente mais pobre do que na esquina da rua; pois, através de uma imitação particularmente sugestiva, o espectador é levado a identificar-se imediatamente com a personagem em ação e deixa assim de pôr as suas questões que eventualmente ainda punha caso estivesse à esquina da rua. ${ }^{213}$

A organização fragmentária da dramaturgia em Mahagonny procura revelar, em um processo de mímesis de uma totalidade contraditória, essa série de causalidades dos fenômenos históricos ligados à produção capitalista dos desejos. O que era para ser tratado como utopia é transformado em uma formação social alegorizada pelo Inferno:

Grandioso é o giro que grotescamente arranca a dialética histórica à coerção natural que até então todavia operara: o furacão faz um arco em torno da cidade e segue seu caminho, da mesma forma que a história o seu, depois de haverem-se encontrado uma vez. Mas o que ocorre na noite do furacão, o que explode e no confuso emaranhado da anarquia alude para além dela, é a improvisação: as canções desarticuladas em que se proclama a liberdade do homem. ${ }^{214}$

${ }^{213}$ BRECHT, Bertolt. A compra do latão. Lisboa: Vega, 1999, p. 93-94.

${ }^{214}$ ADORNO, Theodor. Op. cit., p. 128. 
O que diferencia o inferno presente em Miopia da organização de escombros realizada em Mahagonny e do painel amplo do sofrimento e das lutas de classes tratado na Estética da resistência é a passagem deste furacão mencionado acima por Adorno. Se em Mahagonny o furacão empreende um arco em torno da cidade e segue seu caminho, se a crise capitalista ainda poderia ser enfrentada pela alternativa socialista na Estética da resistência, Miopia é testemunho de um furacão que realizou sua passagem e se incorporou à lógica da produção de valor, gerando crises, lixo e destruição contínuas. A lógica da encenação em Miopia torna-se assim não mais a da dialética entre esperança e desesperança, não mais a da organização de escombros visando a produção sobre a verdade das causalidades históricas; sua encenação é produção contínua de ruínas sobre ruínas.

Se considerarmos as dramaturgias da cena da fundação da cidade de Miopia, veremos esta sobreposição de detritos, sem uma articulação capaz de expressar qualquer totalidade. Para compreender esse acúmulo de dramaturgias, podemos nos remeter à outro curto ensaio de Adorno, desta vez $A$ arte e as artes ${ }^{215}$, texto em que o filósofo esboça a teoria do enodamento ou do emaranhamento das artes:

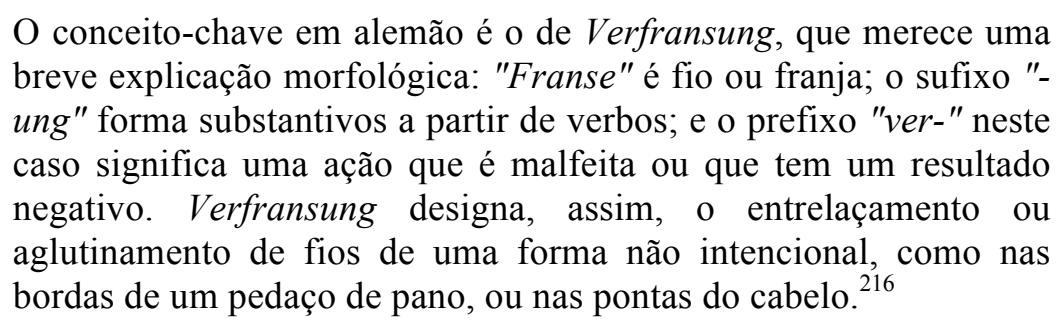

O emaranhamento das artes, aqui, caracterizaria um processo pelo qual os diversos gêneros artísticos romperiam suas fronteiras para gerar um estranho tipo de aproximação, de metamorfose entre os procedimentos e princípios antes segmentados entre os territórios isolados das linguagens:

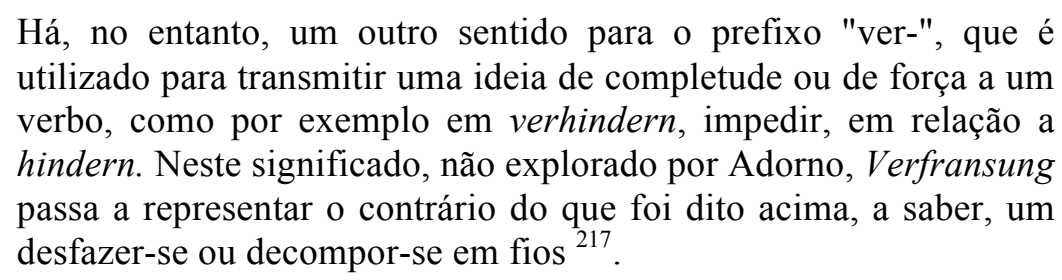

Este desfiar ou franjar na arte contemporânea traduziria a tendência das artes em

\footnotetext{
${ }^{215}$ ADORNO, Theodor. Crítica de la cultura y sociedad I. Madrid: Akal, 2006, p. 390.

${ }^{216}$ DURÃO, Fábio. As artes em nó. Rio de Janeiro: Alea, vol. 5, n. 1, Jan/Jul 2003. In: http://www.scielo.br/scielo.php?script=sci_arttext\&pid=S1517-106X2003000100004\#backx1. Consultado em 12/12/2010.

${ }^{217}$ Idem, ibd.
} 
se recusarem a ocupar um lugar fixo e determinado em uma ordem ou sistema. Delineia-se, assim, uma interessante dialética de afastamento e união que aproxima texto a tecido, tessitura ou textura. A dialética em Miopia, contudo, acrescenta mais uma contradição: o tecer de sentidos realizado pela encenação consuma-se na destruição destes fios que, desfiados, permanecem expostos, aglutinados em busca de um entrelaçamento difícil de ocorrer.

Se tomarmos a cena citada acima, a imagem do Inferno, proposta pelo espaço fechado, tingido de um vermelho sujo por inúmeros ruídos visuais, é sugerida e imediatamente decomposta pela narrativa do texto, voltada para a inauguração da cidade utópica. As paredes arruinadas, com tijolos expostos e máquinas enferrujadas, contribuíam para arruinar ainda mais o sentido infernal da pintura no espaço. $\mathrm{O}$ figurino dos personagens, feito de tecidos de um colorido intenso, apresentava zíperes e costuras expostas: ao longo da temporada, com os tecidos desgastados, os atores permutaram os pedaços de seus figurinos, unindo-os em novas configurações através dos zíperes e de costuras ainda mais improvisadas: o panorama de confusão de subjetividades assujeitadas, de ausência de individualidade, era assim ressaltado por uma cena em que estes figurinos emergiam expostos em toda a sua crueza, devido à luz forte, realizada por velhos refletores teatrais recolhidos de uma empresa falida de aluguel de materiais diversos para festas infantis. Tal exposição de farrapos, no entanto, constituía outro sentido à cena, sem promover qualquer harmonia entre cenário e figurino, um dos preceitos básicos à encenação dramática tradicional. Os objetos utilizados em cena, pedaços de bonecos de isopor e bastões formados por pedaços de cabo de vassoura tingidos de vermelho contribuíam por dar à cena o seu panorama de sucata o que, de resto, também desmentia os inflamados discursos dos personagens.

O programa do espetáculo descreveu tal encenação como uma "constelação de signos", opondo-a à articulação de dramaturgias proposta pela ideia de arte total, conceituada e experimentada na história da encenação desde Wagner. Não me parece que o termo "constelação" possa definir esta relação entre as dramaturgias em Miopia de maneira isenta de contradições. O termo "constelação" indica, na tradição que vem de Adorno e também de Walter Benjamin, em primeiro lugar, a inscrição histórica do objeto. Cada obra artística traria em si, tal como uma mônada, sua história sedimentada como a cifra do seu processo de criação. A narrativa seria, no teatro de Brecht e também no último romance de Peter Weiss, uma exposição dessa constelação histórica que configura a própria obra. Não se trataria simplesmente de uma cadeia argumentativa ou 
da dedução conceitual do conteúdo, nem de proposição e comprovação de teses, mas de uma disposição de conceitos empreendida na obra com o intuito de iluminar a especificidade do momento histórico.

Podemos empregar o termo constelação para definir Miopia apenas se o considerarmos na sua incapacidade, ou na sua capacidade de fracassar. A encenação de Miopia, pela maneira como dispõe seus conceitos em torno dos temas a serem tratados (na cena acima, a transformação da utopia em ruína), forma uma constelação que seria capaz de mostrar como tais conceitos são importantes à reflexão proposta pelas cenas, mas também como são insuficientes para iluminar cada temática em sua singularidade. Tal encenação apresenta a tendência do conceito a identificar-se com seu objeto e, nesta apresentação, contraditoriamente, mostra sua insuficiência para alcançar a especificidade do estilhaço da realidade histórica posto em causa. A constelação dos conceitos de encenação em Miopia orienta o público apenas para iluminar o que escapa à sua lógica, em uma perseguição infinita pelo labirinto. Com isso, a encenação também busca atender à intenção dos conceitos, criando diversas dramaturgias, mas não através de um processo de identificação, segundo o qual os conceitos se ajustam e explicam a realidade histórica, mas sim pela maneira como os acumula não mais a fim de iluminar a realidade mas em busca de expor os seus dejetos, em um processo sem rota contínua. 


\title{
V. Saída interrompida 5: apagamento e memória em Miopia: forma labirinto como memória e usina de detritos/Quinta crise
}

\begin{abstract}
Quando eu despertava assim, e meu espirito se agitava, sem sucesso, tentando saber onde eu me encontrava, tudo girava a meu redor na escuridão: as coisas, os países, os anos. Meu corpo, entorpecido demais para se mover, procurava reconhecer, pela forma de seu cansaço, a posição de seus membros, para perceber a partir deles a direção da parede, o lugar dos móveis, para reconstruir e nomear o local em que se encontrava. Sua memória, a memória de suas costelas, de seus joelhos, de seus ombros, apresentava-lhe sucessivamente os vários quartos em que dormira, enquanto em torno dele rodopiavam nas trevas as paredes invisiveis, mudando de lugar conforme o cômodo imaginado. $O$ que um dia cobriu a terra não está mais sobre ela, mas abaixo; para visitar a cidade morta, não basta uma mera excursão - é preciso fazer escavações. ${ }^{218}$
\end{abstract}

\section{V.1. A forma labirinto e suas classes}

Influenciados por um estudo, empreendido coletivamente, das Teses sobre a filosofia da história, de Walter Benjamin, o tema para o projeto de pesquisa que geraria Miopia foi amadurecido lentamente. Duas das atrizes apresentaram como tema para uma futura peça um livro que coligia toda a correspondência de Olga Benário Prestes. Eu apresentara as Teses, de Benjamin. Os primeiros ensaios foram conduzidos de maneira a experimentar na prática as duas propostas: as cartas de Olga eram lidas e transformadas em improvisações, a partir de diversos exercícios e as teses de Benjamin eram discutidas, geralmente uma a cada final de ensaio. As cenas a partir das cartas acabaram sendo bastante melodramáticas e a leitura e discussão do texto de Benjamin, pouco a pouco, tomou todo o nosso cronograma de ensaio. Novos atores foram incorporados ao trabalho e começamos a escrever juntos um projeto de pesquisa que seria apresentado à Lei de Fomento ao Teatro. O projeto foi contemplado e estabeleceu, a partir de Benjamin, como pressuposto inicial, um distanciamento do que a história oficial celebra como acontecimentos fundadores, que eram para nós naquele momento

${ }^{218}$ PROUST, Marcel. Em busca do tempo perdido. À sombra das moças em flor. Rio de Janeiro: Ediouro, 2004, p. 348. 
essencialmente atos violentos legitimados posteriormente pelo estado de direito. Outro pressuposto dizia respeito à própria memória coletiva: parecia-nos que a glória dos vencedores significava a execração dos soterrados e, por consequência, o armazenamento, nos arquivos da memória coletiva, de feridas simbólicas que pedem uma cura. Esta espécie de excesso de memória lembra muito a compulsão de repetição, a qual, segundo Freud, levaria o sujeito a substituir a lembrança verdadeira, pela qual o presente estaria reconciliado com o passado, pela passagem ao ato neurótico.

Assim, iniciamos o processo de criação teatral considerando que toda a repressão que o Estado autoritário exerceu sobre os comunistas do levante de 1935 ainda esperava por devida rememoração. Esse déficit de crítica não alcançaria o que Freud chamava de trabalho de rememoração.

Nesse ponto, a noção de trabalho - trabalho de rememoração, trabalho de luto, ocupava uma posição estratégica na reflexão sobre as falhas da memória, contra as quais o grupo de autores se insurgiu inicialmente durante a criação do espetáculo. Essa noção supunha que os transtornos enfocados não são apenas sofridos, mas que as classes em luta são responsáveis, cada uma ao seu modo, por eles. Naquele momento uma das atrizes começara a ler Freud e decidimos estudar juntos estas possíveis relações entre memória individual e coletiva. A memória impedida evocada em Rememoração, repetição e perlaboração e em Luto e melancolia é uma memória esquecediça. Freud estabelece nesses textos a seguinte reflexão: o paciente neurótico repete ao invés de lembrar. Ao invés de: a repetição vale como esquecimento. E o próprio esquecimento é chamado de trabalho na medida em que é a obra da compulsão de repetição, a qual impede a conscientização do acontecimento traumático, representada, no início do processo de criação, pela brutal repressão sofrida pelos revolucionários de 1935. A primeira lição da psicanálise é, aqui, fundamental para o início de Miopia: o trauma permanece mesmo quando inacessível, indisponível. No seu lugar surgem fenômenos de substituição, sintomas, que mascaram o retorno do recalcado de modos diversos. A segunda lição é que, em circunstâncias particulares, porções inteiras do passado reputadas esquecidas e perdidas podem voltar. Assim, a psicanálise seria, para o artista e para o filósofo, um aliado a favor da tese do inesquecível. Uma das convicções mais firmes de Freud foi mesmo que o passado vivenciado é indestrutível. No entanto, o trabalho da rememoração não se dá sem o trabalho de luto pelo qual quem tenta se lembrar se desprende dos objetos perdidos do amor e do ódio.

Ao escolher como tema a chamada Intentona Comunista de 1935, tornou-se 
inicialmente fundamental para a II Trupe de Choque, durante a construção do espetáculo, a busca por uma forma capaz de gerar essas "circunstâncias particulares" que podem fazer o passado apagado ressurgir na potência da arte. A primeira questão formal relacionada ao enfrentamento do fato histórico apagado foi a da construção narrativa. No início do projeto, lembro-me que debatemos muito sobre a função mediadora da narrativa, sobre os abusos de memória que se tornam abusos de esquecimento. De fato, antes do abuso, há o uso, a saber, o caráter inelutavelmente seletivo da narrativa. Parecia-nos que assim como é impossível lembrar-se de tudo, é impossível narrar tudo, que deveríamos assumir pontos de vista claros sobre o tema escolhido para a peça. A ideologização da memória é possibilitada pelos recursos de variação que o trabalho de configuração narrativa oferece. As estratégias do esquecimento enxertam-se diretamente nesse trabalho de configuração: pode-se sempre narrar de outro modo, suprimindo, deslocando as ênfases, refigurando diferentemente os protagonistas da ação assim como os contornos dela. $\mathrm{O}$ recurso à narrativa torna-se assim armadilha, quando potências superiores passam a direcionar a composição da intriga e impõem uma narrativa canônica por meio de intimidação ou sedução. Está em ação aqui uma forma ardilosa de esquecimento, resultante do desapossamento dos atores socais de seu poder originário de narrarem a si mesmos. Para nós, no início, o objeto do trabalho seria a possibilidade de narrarmos, para usar as palavras de Paulo Emílio, "a penosa construção de nós mesmos, que se desenvolve na dialética rarefeita entre o não ser e ser outro". Se "nada nos é estrangeiro, pois tudo o é", queríamos testar a possibilidade de se fazer teatro político na periferia de São Paulo, ocupando espaços degradados, em confronto com referências teatrais afeitas ao pensamento dialético, já que pretendíamos contradizê-las, elegendo como tema um fato já quase esquecido nas teias da história brasileira. Estas referências iniciais todas aos poucos foram sendo soterradas pelas questões que a prática criativa levantava mas tiveram parte no labirinto formado pela peça, ainda que a importância destas referências para o resultado de Miopia tenha sido a da sua denegação.

A partir da escolha do pequeno parágrafo de Leôncio Basbaum como eixo narrativo norteador não se estava diante, para tratar do movimento comunista de 1935 , de nenhum personagem histórico heroicizado, mesmo que os da história não-oficial. As figuras de Prestes e Olga, bem como a deflagração dos levantes e a sua repressão posterior estavam assim descartadas. Além do objetivo dialético de não considerar o movimento histórico como gerado por figuras atomizadas, havia uma escolha narrativa 
política: para que o passado fosse rememorado, saltando como um tigre para irromper no presente, a constelação do capitalismo tardio precisava ser considerada e, neste labirinto, qualquer ideia de revolução estaria distante no horizonte.

Um dos leitmotiv a que o repertório ideológico do liberalismo, mesmo o de terras periféricas, mais recorre é a noção do desaparecimento das classes. Em geral, esse argumento é transmitido sob a forma de observação empírica, mas pode assumir uma enorme variedade de formas; a mais presente talvez seja a noção de um rompimento qualitativo, um salto gigantesco dos velhos modelos industriais para o que atualmente veio a ser denominado sociedade "pós-industrial". Esta versão reflete as realidades da transição de um capitalismo monopolista para um estágio mais propriamente consumista, que assume, pela primeira vez, uma escala global e tenta tirar proveito do surgimento desse novo estágio do capital para sugerir que o modelo econômico marxista clássico não é mais viável. De acordo com esse argumento, estamos diante de um processo de homogeneização social em que as antigas diferenças sociais estão em via de desaparecer. Esse processo pode ser descrito como o aburguesamento do trabalhador, ou, melhor ainda, como a transformação, tanto do burguês quanto do trabalhador, naquele indivíduo de constituição neutra, conhecido como consumidor. Estão todos sempre prontos a sugerir que vivemos no que vem se tornando uma "economia de serviços", em que a produção nos moldes clássicos ocupa uma porcentagem cada vez mais reduzida da mão de obra.

Para nós da II Trupe que estávamos sediados em uma Usina de Compostagem de Lixo abandonada, ministrando oficinas com catadores de lixo e com os moradores da região, de inúmeras favelas construídas/destruídas à beira do córrego Aricanduva, esta homogeneização social sempre pareceu ideologia e a questão de como representar os desfiliados era levantada ensaio a ensaio, improvisação a improvisação. Se seguirmos as pistas de Jameson em busca da saída deste labirinto:

Chamaremos a esse requisito básico, agora tomando o termo emprestado a Freud, em vez de Marx, de requisito de figuração; para que esse requisito se cumpra, a realidade social e a vida cotidiana deverão ter se desenvolvido de tal modo que sua estrutura de classe subjacente se torne representável sob formas tangíveis. ${ }^{219}$

Pode-se apresentar o mesmo argumento de outra forma, salientando o papel extraordinariamente vital a ser desempenhado pela cultura nesse processo, cultura não

${ }^{219}$ JAMESON, Fredric. As marcas do visível. Rio de Janeiro: Graal, 1995, p. 39. 
só como instrumento de autoconsciência, mas, antes, como um sinal e um sintoma da autoconsciência possível. Durante todo o processo de ensaio nos pareceu que a relação entre consciência de classe e figuração, em outras palavras, requeria algo mais básico que o conhecimento abstrato e implicava uma forma de existência mais visceral do que as certezas abstratas da economia e da ciência social marxistas: esta última simplesmente continuava a nos convencer da presença determinante, por trás da vida cotidiana, da lógica da produção capitalista. Entretanto, para que a verdadeira consciência de classe fosse possível, nos parecia que precisávamos começar a perceber a verdade abstrata da classe pelo meio concreto da vida cotidiana, sob formas expressivas e empíricas; e afirmar que a estrutura de classe tornou-se representável significaria dar um passo além da mera compreensão abstrata e entrar no terreno que engloba a imaginação individual, as histórias que contamos como coletividade, a figuração narrativa - que é o domínio da cultura, e não mais da sociologia abstrata ou da análise econômica. Para se tornarem representáveis - isto é, visíveis, acessíveis à imaginação - parecia-nos naquele momento que as classes precisariam ser capazes de se transformar em personagens.

A cena que será exposta a seguir, a cena 16 da peça, foi trabalhada durante muitos meses e teve inúmeras versões de texto e de encenação. A primeira impressão que sempre tínhamos da cena, e o público que a assistia nos ensaios abertos também pensava o mesmo, era a de um aborrecimento sem fim. Por mais que cortássemos o texto, a cena nunca ganhava agilidade e parecia que a situação não se desenvolvia, que o conflito entre os personagens não se estabelecia:

\section{O AUTÔMATO TURCO VAI AO CINEMA}

Casa de Fausto. O cinematógrafo está ligado, projetando imagens. Tudo parece abandonado e apodrecido. Batem na porta.

FAUSTO - Sim. Quem é? É você, Azevedo? Entra, está aberto. Entra Belmiro. Boa tarde, senhor Belmiro. A última pessoa que eu poderia imaginar.

BELMIRO - Não estou incomodando o trabalho do senhor prefeito?

FAUSTO - Sente-se, por favor. Aqui estou eu, senhor Belmiro. Estou pisando nos meus filmes, estou derretendo-os. Quero começar tudo de novo. Eles não são para este mundo.

BELMIRO - Venho da parte de alguém que o senhor conhece. Sobre um assunto que o senhor também conhece. É melhor não perdermos tempo. Eu venho da parte do Mackee.

FAUSTO - Mackee. O que é que tem o Mackee?

BELMIRO - É muito simples. Ele conseguiu maioria com os acionistas da empresa para que liberem os filmes para a exibição no cinema. 
FAUSTO - Filmes ou propagandas?

AUTÔMATO - O Mackee não é um produtor cultural, ele é apenas gerente de uma empresa de lixo em Chicago. Estes filmes são jogados fora pelas empresas e ele recolhe, para exportação.

FAUSTO - O que quer o Mackee?

BELMIRO - Ele só quer uma garantia de que as obras da construção do cinema sairão do papel.

FAUSTO - Desculpe, mas já não me interessa. Faz três anos que eu estou aqui por causa disso, e só por causa disso. E duas ou três vezes por ano o Mackee me faz saber que está tudo acertado. Agora eu dou risada. Compreende? Neste povoado imundo. E eu fui ficando, apodrecendo aqui. Não me incomodo de dizer, o senhor sabe disso. E agora vem com outro aviso, tem a pouca vergonha de mandar vir o senhor, logo o senhor. Mas para mim acabou, já chega desta cidade.

BELMIRO - O Mackee ficou feliz em saber que a desapropriação já está seguindo normalmente, apesar dos transtornos.

CORO DE SEM-TETO - Nós somos Sem-Teto, senhor Prefeito.

Nossas casas foram derrubadas para a construção do cinema

E do Progresso. Fomos julgados culpados

Em todos os processos.

Agora nós somos Sem-teto. Culpados por habitar

Os terrenos do futuro. A indenização não vai dar

Nem para pagar os ferimentos causados pelas balas da polícia.

FAUSTO - Isso é coisa de comunista. Eu não me importo mais.

BELMIRO - Eu entendo. De qualquer modo, dessa vez é certo. Não porque o Mackee tenha dito. Mas porque as circunstâncias da realidade pedem que assim seja. E ninguém pode lutar contra a realidade, como diria Karl Marx.

FAUSTO - Desta vez é certo? E se eu lhe dissesse, meu caro comunista, que acredito no senhor, e por estar acreditando que é verdade, que desta vez é certo, tenho vontade de quebrar a pontapés todos os móveis, e o meu gabinete, esses americanos e toda esta merda de cidade? Desculpe. Pode dizer ao Mackee que eu vou embora. Estava louco, estive louco nesses anos e só agora percebo. Agora que é certeza, entendeu?

BELMIRO - Interessante. Mas dá para entender. Mas isso tudo, tudo o que diz, é assunto entre Mackee e o senhor. Eu vim dizer-lhe que ele conseguiu maioria entre os acionistas e eles vão enviar os filmes de propagandas. O prefeito de Miopia não tem interesse e pronto, isso é tudo. Amanhã direi ao Mackee que o senhor não está mais interessado.

FAUSTO - Vamos descer juntos então, estava de saída. Este inverno é muito traiçoeiro, principalmente aqui, que é costa de lago. Obrigado e desculpe, Senhor Belmiro. Pensando bem, pode ser que eu ainda faça negócio com Mr. Mackee.

CORO DOS SEM-TETO - A primeira sessão do cinema de comerciais será destinada, gratuitamente, para todos os que foram desapropriados pela Prefeitura. Estamos bastante satisfeitos por saber que nossos nomes serão imortalizados, na placa dourada na frente do cinema, como patronos deste projeto cultural. Não 
cedemos e nossas reivindicações foram atendidas. ${ }^{220}$

A cena só ganhou interesse, para nós mesmos, quando percebemos do que estávamos tratando: a cena não tinha conflito porque talvez tratasse da luta de classes. Não a luta de classes da modernidade, mas a luta de classes contemporânea, a que opunha desfiliados e consumidores, em um processo que os que não têm acesso aos bens de consumo querem ser incluídos e os donos da vida querem continuar fazendo parte do jogo, de preferência com exclusividade. Passamos a ensaiar direcionando o foco da encenação não mais para o confronto entre Belmiro, o empresário rico da cidade, representante dos interesses norte-americanos, e Fausto, o prefeito nacionalista, representante do Estado, mas sim para o coro dos sem-teto. Não nos interessava tratar do conflito entre a burguesia nacional e as empresas mundializadas ou o conflito entre o proletariado e a aliança entre Estado e burguesia. Estes conflitos diziam respeito aos anos 30, ao nosso tema de estudo, mas que devia ser suspendido se pretendíamos expressar questões da nossa atualidade, de uma nova configuração da luta de classes.

Nesta nova configuração, o tema escolhido passou então a ser resistência dos desempregados, dos párias, dos que vivem à margem, excluídos mesmo de um movimento de oposição organizado. Esta escolha dialoga com Iná Camargo Costa, para quem

a luta de classes não pode ser invocada apenas quando a classe operária, através de suas organizações, está na ofensiva. Também temos luta de classes quando a classe dominante barbariza. Luta de classes é a luta pela redistribuição da propriedade e de todos os recursos produzidos pela sociedade como um todo. Está sendo travada todos os dias, mas nos últimos tempos é a burguesia que vence a cada confronto. Os ideólogos dizem que ela foi neutralizada, mas isto é falso e esta falsificação faz parte da própria luta. Uma das artimanhas dos atuais vitoriosos é dizer que não há mais luta de classes. Um teatro que tem este conhecimento lança luz de preferência sobre os modos como a classe dominante exerce o seu poder de modo bárbaro. ${ }^{221}$

O modo bárbaro como a classe dominante exerce o seu poder foi experimentado na encenação a partir da relação dos dois personagens filiados ao reino da mercadoria, Belmiro e Fausto, com os desfiliados da cena, os desapropriados pela construção do cinema de comerciais. A cena passou a ser representada em uma ampla sala de

${ }^{220}$ ALMEIDA, Ligia Marina; DELMANTO, Ivan; FARIA, Fernanda, et al. Miopia. Inédito, 2006, p. 14-15.

${ }^{221}$ COSTA, Iná Camargo. O Nome do jogo, prefácio in: Cia. Do Latão: 7 peças. São Paulo: Cosacnaify, 2008 , p. 18. 
máquinas da Usina: Fausto e Belmiro passavam a cena inteira em cima das máquinas, pulando de uma para outra, como se as dominassem. O coro dos sem-teto não aparecia: os atores estavam no andar debaixo da Usina e a cada inserção do coro Belmiro ou Fausto abriam uma escotilha - que fazia parte de uma das máquinas e dava acesso ao andar debaixo, provavelmente servia para o escoamento do lixo -, e permitiam que a voz do coro fosse ouvida e, portanto, participasse da cena.

Há na primeira inserção do coro um leve tom reivindicatório, que não chega a se tornar explícito. Já na segunda entrada, que tem a função narrativa de anunciar que o prefeito aceitou o acordo com a empresa norte-americana e que o cinema de comerciais será inaugurado finalmente, o coro anuncia sua capitulação em troca de alguns ingressos para os filmes. A visão pessimista sobre os movimentos sociais não deixa de dar testemunho de uma nova colisão de classes: a cena não aponta para uma ausência de conflito, mas para uma resolução aparentemente pacífica dos embates a favor da barbárie; os moradores foram expulsos de suas casas, estão sem teto e a colonização de subjetividades empreendida pela difusão universal e absoluta da forma mercadoria produz pacificação e anestesia voluntariamente. O prefeito e o empresário são responsáveis pela desapropriação, mas o responsável pelo pacto e pela domesticação dos sem-teto não tem cara ou personalidade, não é figurado em personagem, mas é apresentado na peça por esta generalização da mercadoria como mediação social.

A estrutura de Miopia, assim, não é mais dual, como no drama ou no teatro épico “clássicos" em que o conflito movia a narrativa, mas configura uma realidade saturada por uma constelação de contradições sem fim, presentes na forma labirinto. Se na forma dramática a figuração de um momento histórico específico revela as classes claramente desenhadas em sua oposição, há na apresentação labiríntica de Miopia, de uma realidade em que a cartografia do drama é dissolvida nos apresentando uma realidade não mais transparente, a própria estrutura caótica da obra e da forma mercadoria figurando a luta de classes.

O labirinto de Miopia talvez seja a figuração de um processo histórico em que a ideia de luta de classes foi sendo obstruída pela prática coletiva de grupos sociais, particularmente os de estudantes, negros, mestiços e mulheres. O que, para além das artimanhas da ideologia, poderia ser percebido nas esquinas e becos do labirinto é que as reivindicações de justiça e igualdade proclamadas por esses grupos não são (ao contrário da política de classe social) intrinsecamente subversivas (as bisonhas manifestações contra as imagens que marcam algumas das cenas de Miopia são 
exemplo desta situação). Em vez disso, os slogans do populismo e os ideais de justiça racial e igualdade sexual já eram em si mesmo integrantes do próprio Iluminismo, inerentes a uma denúncia socialista do capitalismo, mas também até mesmo à revolução burguesa contra o antigo regime. Assim, os valores dos sem-teto presentes nesta cena da peça (ou os valores dos movimentos pelos direitos civis, do movimento feminista e o igualitarismo do movimento estudantil) seriam notadamente cooptáveis, porque já estariam - como ideais - inscritos no cerne ideológico do próprio capitalismo; além disso, podemos considerar, a partir do coro dos sem-teto presente em Miopia, a possibilidade de que esses ideais sejam parte da lógica interna do sistema, que tem um interesse crucial na igualdade social, na medida em que precisa dela para transformar o maior número possível de sujeitos ou cidadãos em consumidores idênticos, intercambiáveis com qualquer outro indivíduo. A posição marxista - que inclui os ideais do Iluminismo mas procura fundá-los em uma teoria materialista de evolução social - argumenta em contrário que o sistema é estruturalmente incapaz de realizar esses ideais, mesmo onde haja interesse econômico em fazê-lo.

A forma de Miopia nos conduz pelo labirinto de um momento histórico em que a luta de classes é difícil de ser identificada, em que os posicionamentos coletivos são obscurecidos na colonização da subjetividade exercida pelos imperativos da forma mercadoria. No entanto, a aparência caótica pode ter seus segredos revelados se pudermos traçar a cartografia deste labirinto. E o mapa deste espaço sem saída, se não estivermos errados, seria traçado pelos conflitos de classe, em última instância, cerne das inúmeras contradições que geram o aparente caos da forma labiríntica. A constelação de contradições que forma o espetáculo seria assim figuração de uma realidade em que a violência do confronto de dois mundos, o sufocamento dos que querem aderir ao mundo do consumo e a ultramodernidade desfiliante do capitalismo, surge como insuportável explosão. O lixo pisoteado pelos personagens e pelo público seria a voz soterrada das vítimas dessa explosão. As inúmeras tentativas de sair desse labirinto, empreendidas pelo público em seu percurso conduzido por uma fícção administrada, esbarrariam também na ausência de saídas que marcam o momento histórico contemporâneo.

O grupo acreditava, desde o início do projeto de pesquisa, que uma peça capaz de tematizar a expulsão bárbara de desempregados, jogados como lixo nos confins do país, deveria buscar formas narrativas opostas às da narração oficial, capazes de superar este recalque histórico de dialogar com as relações opressoras do presente. A seguir veremos 
como se estruturou a narrativa de Mércia, uma das narradoras que assumia explicitamente este ponto de vista a contrapelo da ideologia. A contradição, porém, está no fato de que, durante o processo de criação, o grupo percebeu que este único ponto de vista linear não conseguia contemplar uma realidade hipostasiada por simulacros e espetáculo: a peça ganhou então uma forma labiríntica em que o alarido de inúmeras vozes dissolveu a narrativa, criando um percurso por entre ruínas em que o público situava-se sob a cloaca destas relações sociais, em uma posição de difícil legibilidade. Esta dificuldade de leitura e de encontrar saídas para as alegorias e imagens apresentadas configurou-se como a própria forma do espetáculo, em realização totalmente distinta do que pretendiam os autores de Miopia.

O crítico literário Dolf Oehler, quando estuda autores da modernidade, afirma que estas obras não podem ser entendidas sem se levar em conta a experiência das jornadas de 1848:

As jornadas de junho de 1848 não representam apenas uma das datas mais dolorosas da história do século XIX, um "pecado original da burguesia" (Sartre), que dividiu a nação francesa em dois campos, e cujo recalque - ao contrário da história análoga da Comuna - nunca foi realmente superado (...) A isso se soma que o substrato histórico dos textos canônicos (Heine, Baudelaire, Flaubert) foi tanto cifrado pelos próprios autores quanto soterrado pela história de sua recepção. ${ }^{22}$

Seguindo um raciocínio linear, assim como o Cisne de Baudelaire não pode ser entendido sem a rememoração do massacre de junho de 1848, Miopia, e todo o seu processo de construção, não poderia ser lida sem que o diálogo entre o presente do grupo - seu modo de produção, os espaços em que a peça foi criada e as questões políticas de seu tempo - e o passado das “jornadas de 1935" fosse relacionado. Esta afirmativa estaria correta se houvesse linearidade e transparência entre as intenções dos autores de uma obra artística e a sua materialização. Tal relação imediata não pode ser testemunhada no processo de criação de Miopia e talvez resida neste curto-circuito o interesse de tal processo.

No início da criação de Miopia, o contexto histórico de 1935 (e as formas de repressão violentas empregadas contra qualquer forma de resistência) fora pensado para revelar "os modos como a classe dominante exerce seu poder de modo bárbaro". No entanto, a rememoração desse processo de ensaio, registrado diariamente nos meus

${ }^{222}$ OEHLER, Dolf. O velho mundo desce aos infernos. São Paulo: Cia. Das Letras, 1999, p. 22. 
cadernos de direção, revela que, pouco a pouco, o fato histórico que o grupo fazia questão de nomear como "jornadas" em clara alusão a junho de 1848, foi sendo esquecido pela própria forma do material cênico que estava sendo criado. O resultado final da peça sequer menciona a repressão do movimento político liderado pelo PCB em 1935.

\section{O ANJO DO DESESPERO}

MÉRCIA - Chega dos narradores da aranha, que tecem suas histórias a partir do próprio veneno, se alimentando apenas da própria teia. Eu vou contar como as abelhas, limpa e claramente, trabalhando a partir da matéria do mundo. Não deixem a chama apagar! Mantenham as luzes da cidade acesas! Não deixem a chama apagar! A partir de agora, a história do nascimento de uma chama. E das cinzas. Só restaram cinzas. Eu acompanho a História da mesma fileira dos desvalidos, dos miseráveis, dos perdidos nos labirintos das vitrines porque já não podem mais sonhar com o que o dinheiro pode comprar. Agora vocês vão ouvir a História, escrita por aqueles que não conhecem a língua, que perderam as palavras e que só podem se comunicar quando as bombas começam a soar no lugar dos sinos. (Distribui lanternas para o público. A lanterna de Rosa não acende. Mércia conduz. Rosa permanece, tentando acender a lanterna.)

7. PRAÇA E PRAGA

São Paulo. Praça dos desempregados.

DIOTIMA - A CANÇÃO DO EMPREGO

Ai de nós, entre os gigantes

A luta novamente explode.

Quem a pagará?

Certamente não será o gigante.

DIOTIMA - Bem vindos, trabalhadores de São Paulo! É um prazer ser Diotima Hansen para vocês! Hoje viveremos uma imensa celebração ao Trabalho! (Lendo.) Pela primeira vez na história, as centrais sindicais e o governo estão de mãos dadas para conduzir o país rumo ao progresso! E como símbolo deste país unido, sem classes sociais, em um pacto rumo ao futuro, teremos hoje, aqui, daqui a pouco, o sorteio de uma dúzia de empregos!

BELMIRO - Isto é exploração da classe operária!

ROSA - O povo não é carneiro! Abaixo a exploração e a ditadura disfarçada de Vargas! (Montado em um cavalo, um policial se aproxima.)

DIOTIMA - Antes do sorteio de uma dúzia de empregos, aqui, daqui a pouco, neste lugar que já foi chamado, não sem crueldade, de Praça dos Desempregados, quero que acompanhemos o incrível espetáculo de dança da famosa Escrava Zuzu! (Aplausos.)

BELMIRO - Viva Luis Carlos Prestes!

VOZES - Viva!

FAUSTO FALSTAFF - Viva Vargas, o pai do povo! 
Entra a escrava Zuzu, que começa a dançar. Tem nas mãos correntes e na boca uma focinheira. Carrega um chicote, que usa em seus momentos mais masoquistas. Entra um discurso de Vargas.

DIOTIMA - Trazemos em nossas vidas a influência do povo negro (uma projeção da Escrava Zuzu hipnotiza e atrai os trabalhadores), que nunca perdeu a nobreza dos sentimentos, mesmo quando ainda eram escravizados. Quem se esquece da escrava que nos embalou? Que nos deu de mamar. Que nos deu de comer. Da negra velha que nos contou as primeiras histórias de bicho e de mal-assombrado. Da mulata que nos tirou o primeiro bicho-de-pé de uma coceira tão boa. Da escrava que nos iniciou no amor físico e nos transmitiu, no ranger da cama de vento, a primeira sensação completa de homem. Por isso aqui estamos para nos encantar com a Escrava Zuzu: a legítima representante do povo brasileiro, que está aqui para celebrar a harmonia dos povos, das classes e das raças neste imenso país! Depois de uma turnê de sucesso na Alemanha, na Itália e no Japão, a Escrava Zuzu aterriza em São Paulo para nos encantar com sua sensibilidade, harmonia de proporções e simpatia! (O público é conduzido a um recinto fechado. $O$ baú de caminhão).

BELMIRO - É uma armadilha de Vargas! (As portas do caminhão se fecham). ${ }^{223}$

A praça dos desempregados era a sétima cena da peça. Antes dela, o público contornava a Usina sem encontrar entrada, assistindo a fragmentos embaralhados que, sem uma linha temporal e espacial definidas, eram incapazes de narrar a história de Miopia. Neste primeiro movimento da peça, acompanhava-se a história contada sob o ponto de vista da narradora emudecida, Rosa Medeiros, e por isso a desorientação do percurso e das situações apresentadas. Na cena 6, Mércia, a arquiteta do cinema de comerciais, tomava a palavra e passava a narrar: acompanhava-se então sua narração da história, sob seu ponto de vista, que procurava dar voz às vítimas do processo civilizatório de construção/destruição da cidade de Miopia. Mércia entregava lanternas ao público, daquelas presas em capacetes, muito utilizadas pelos trabalhadores de minas de metais preciosos como o ouro. A luz que Mércia desejava que o público se responsabilizasse por manter acesa era a luz do próprio ato de narrar, em um momento da peça em que parecia que a História poderia ser articulada, compreendida e transformada. A iluminação das cenas durante toda a narração e condução de Mércia ficava a cargo das lanternas do público, que iluminava cada situação como preferisse.

\footnotetext{
${ }^{223}$ ALMEIDA, Ligia Marina; DELMANTO, Ivan; FARIA, Fernanda, et al. Miopia. Inédito, 2006, p. 7 8.
} 
Geralmente o narrador de cada trecho da peça era responsável também por conduzir o público pelo espaço da Usina, procurando articular as cenas apresentadas: nesse processo de condução, Mércia procurava manter as luzes de sua narrativa literalmente acesas, colocando o público do seu lado da história, como soterrados.

A cena seguinte, que narra o que aconteceu na praça dos desempregados, é o início desta narrativa. Já vimos no capítulo 1 desta dissertação, como esta cena, a sétima da peça, tratava o público com um misto de brutalidade e sedução. Vale a pena retomarmos a sequência de ações presentes neste fragmento de Miopia: o próprio público era tratado como se fossem todos desempregados, participantes do comício e depois vítimas da higiene social promovida pelo Estado, sendo amontoados e encarcerados em um escuro e pequeno baú de caminhão. A ausência de uma exposição analítica das contradições, gerada pelo fato do público simplesmente sofrer na própria pele a violência narrada na cena, era marca de toda a narração de Mércia que procurava, obsessivamente, apagar sua responsabilidade na construção da cidade com uma versão da história que estivesse do lado "das vítimas". A transformação do real em espetáculo já começava a ser explorada pela encenação neste momento da peça: em um primeiro palanque o público/desempregados acompanhava o show da cantora Diotima; em um tablado mais distante, que era usado na troca de óleo dos veículos da Usina, ocorria o show da Escrava Zuzu, fantasma responsável por conduzir o olhar e os desejos do público e dos personagens durante cena. A imagem do número de dança masoquista de Zuzu era projetada em uma tela, do lado oposto em que a cena "real" ocorria: policiais entravam para conduzir o público e os personagens, marchando e batendo os cacetetes em seus escudos na direção da projeção. O estado tanto dos policiais quanto dos personagens que protestavam contra o governo tornava-se hipnótico, atraídos pela beleza da imagem fantasmática projetada na tela branca. Lentamente, todos eram empurrados, esmagados, em direção à tela, até que a atravessavam: do outro lado, as portas abertas de metal marcavam a entrada direta ao cubículo do baú do caminhão, que era prontamente fechado, encarcerando público e personagens.

O episódio da praça dos desempregados, que não contou com nenhuma intervenção ativa do PCB, e que retrata a violenta "re-alocação" da força produtiva do exército industrial de reserva paulistano, aparece como marco inaugural de Miopia mas para também desaparecer depois, não sendo mais sequer mencionado dentro da narrativa, dando lugar à demonstração do processo de desenvolvimento de uma cidade que surge como utopia igualitária e desmorona diante da importação das mesmas 
relações sociais, baseadas na forma mercadoria, que já haviam produzido o lixo humano da praça dos desempregados. Assim, mesmo sem ter a consciência clara disso, os criadores de Miopia se afastaram de suas intenções iniciais porque era impossível considerar o episódio de 1935 como fato traumático na história brasileira. Provavelmente, o esquecimento da Intentona, ao contrário das jornadas de 1848, esteja ligado não ao recalque de um trauma mas à precariedade da iniciativa de se tentar a revolução comunista em moldes soviéticos em um país assolado pelas contradições de um passado colonial ainda presente, o que configurava, naquele momento histórico, o Brasil como paraíso da acumulação capitalista e - se usarmos os termos do marxismo clássico - em uma situação em que a formação social não impedia o avanço das forças produtivas, pelo contrário, o que se via era o progresso das relações capitalistas por aqui. Segundo Francisco de Oliveira:

A industrialização, em sendo tardia, se dá num momento em que a acumulação é potencializada pelo fato de dispor, no nível do sistema mundial como um todo, de uma imensa reserva de trabalho morto que, sob a forma de tecnologia, é transferida aos países que iniciaram o processo de industrialização recentemente. Assim, na verdade, o processo de reprodução do capital "queima" várias etapas, entre as quais a mais importante é não precisar esperar que o preço da força de trabalho se torne suficientemente alto para induzir as transformações tecnológicas que economizam trabalho. ${ }^{224}$

Este avanço do capitalismo à brasileira, em que as contradições de uma formação social de "especificidades particulares" gera um desenvolvimento das relações de produção "queimando etapas", transformou a tentativa de revolução comunista neste momento histórico em utopia farsesca. O apagamento, no resultado final de Miopia, do que era a sua temática inicial testemunha este percurso do capitalismo brasileiro que "queimou" a etapa das revoluções burguesa e proletárias, em um desenvolvimento que Carlos Nelson Coutinho, a partir de Lênin, chamou de "via prussiana":

Diverso é o caso da via prussiana: aqui, a velha propriedade rural, conservando sua grande dimensão, vai se tornando progressivamente empresa agrária capitalista, mas no quadro da manutenção de formas de trabalho fundadas na coerção extraeconômica, em vínculos de dependência ou subordinação que se situam fora das relações impessoais do mercado. (...) Característica da via não clássica ou prussiana é precisamente essa complexa articulação de progresso (a adaptação ao capitalismo) e

${ }^{224}$ OLIVEIRA, Francisco de. Crítica à razão dualista. O ornitorrinco. São Paulo: Boitempo, 2003, p.67. 
conservação (a permanência de importantes elementos da antiga ordem). ${ }^{225}$

A presença de tal processo de modernização conservadora, de formação supressiva, pode ser vista nas múltiplas contradições presentes no labirinto da peça, o que conduz, em muitos aspectos, à supressão formal, realizada pela encenação, dos elementos épicos presentes no texto. Tais elementos não foram abandonados, mas permaneceram integralmente no texto para serem soterrados pela encenação. A arquitetura do labirinto surge desta articulação de elementos díspares, articulação que não harmoniza as diferenças mas as coloca em atrito até a sua explosão. Com relação à reflexão histórica, mais do que fazer ressurgir o passado emudecido, interessou ao grupo, a partir do instante que a Intentona era obscurecida pelo avançar do processo de criação, "encontrar a constelação do despertar: trata-se da dissolução da mitologia no espaço da história."226

E mais ainda:

Reconhecer, nas formas aparentemente secundárias e perdidas daquela época, a vida de hoje, as formas de hoje. (...) Cada agora é o agora de uma determinada cognoscibilidade. Nele, a verdade está carregada de tempo até o ponto de explodir. Não é que o passado lança luz sobre o presente ou o presente lança luz sobre o passado: mas a imagem é aquilo em que o ocorrido encontra o agora num lampejo, formando uma constelação. ${ }^{227}$

A afirmativa benjaminiana de que articular o passado historicamente não significa conhecê-lo "tal como ele propriamente foi" tornou-se vital para o grupo desde o início da pesquisa. "Apoderar-se de uma lembrança tal como ela lampeja num instante de perigo", passou a significar uma recriação imaginária capaz de fixar, no instante de perigo do presente, o que poderia ter acontecido aos desempregados da praça se tentassem sobreviver à sociedade que os excluiu criando novas formas de existência comuns. A imaginação da lembrança passou a significar mais do que a sua rememoração.

Neste sentido, a pergunta lançada por Dolf Oehler: "a quem, entre aqueles que hoje cruzam a Place Saint-Michel, as figuras da fonte de mesmo nome, cercada de garrafas de cerveja e de Coca-Cola, tem ainda algo a dizer?" talvez seja aqui

${ }^{225}$ COUTINHO, Carlos Nelson. Cultura e sociedade no Brasil. Rio de Janeiro: Oficina de Livros, 1990, p. 118

${ }^{226}$ BENJAMIN, Walter. As Passagens. Belo Horizonte: Ed. UFMG; São Paulo: Imprensa Oficial do Estado de São Paulo, 2006, p. 500.

${ }^{227}$ Ibd., p. 505-511. 
fundamental para a compreensão de Miopia. Não seríamos mais capazes de decifrar historicamente aquela alegoria para turistas, de reconhecer que o arcanjo de espada em punho, nos ombros de Satanás, representou em sua época a vitória da ordem imperial e burguesa sobre a revolução porque "a chave de compreensão de ambas as obras de arte - o código alegórico da época - foi perdida". Sem o conhecimento da semântica histórica da modernidade, é se naturalmente tentado a tomar o caráter indecifrável das alegorias como característica do seu uso moderno. Walter Benjamin já via na chave de decifração da alegoria barroca o luto, que ligamos acima à experiência da rememoração:

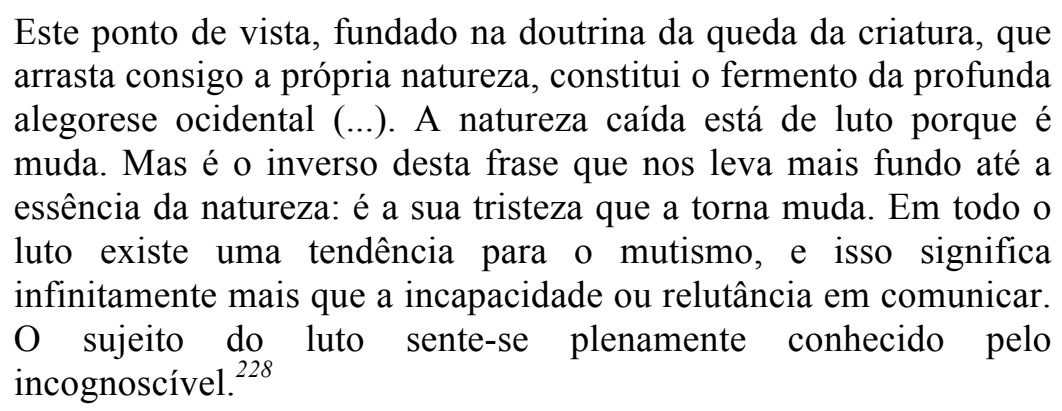

Se para Dolf Oehler, as jornadas de junho de 1848 estão no centro da escrita de Baudelaire, Heine ou Herzen, fixando o olhar do intelectual atingido, obcecado pela recordação do massacre como um crime coletivo, no qual ele, por maior que seja a ruptura com sua classe, tem, não obstante, uma parcela de culpa, o mote de rememoração, presente nas alegorias mudas de Miopia estaria relacionado a outro pecado original.

A hipótese que pretendemos testar - a chave alegórica que veremos se é capaz de abrir as trancas de difícil abertura -, aponta como o "pecado original", presente pela primeira vez no Brasil no contexto histórico de 1935, a chegada da indústria cultural por aqui. O código alegórico que une o tempo dos criadores do espetáculo ao tempo da praça dos desempregados está ligado ao que transforma a todos de cidadãos em consumidores, ao que os rende às seduções da forma mercadoria, desenvolvidas a partir deste momento histórico como prática do espetáculo. Com a expansão do cinema, chegavam ao Brasil as primeiras propagandas, exibidas também como imagem, seja como filmes, seja como anúncios de revistas, jornais ou placas nas ruas. Os anúncios publicitários tornam-se cada vez menos baseados na palavra e passam a se estruturar sobre imagens. Este percurso é alegorizado em Miopia pela grande construção arquitetônica da cidade utópica fundada pelos desempregados: o cinema que só exibe

${ }^{228}$ BENJAMIN. Walter. Origem do drama trágico alemão. Lisboa: Assírio \&Alvim, 2006, p. 248. 
comerciais:

GRAVAÇÃO - Dentro de instantes daremos início à inauguração do fantástico cinema de Miopia. Esta festa foi realizada graças a uma parceria entre a prefeitura de Miopia, a Autômato Turco Construtora de Bonecos e a Garbage Shop, empresa norteamericana e fornecedora dos filmes comerciais a serem exibidos neste cinema. Com vocês, A Voz! Diotima Hansen, vinda direto de São Paulo para o cinema de Miopia!

CORO - Muito bem! Muito bem!

DIOTIMA - Uma nova aurora

Voando ao futuro, cheios de agora

Maduros projetamos no cinema

Um novo mundo. (Começa a dançar perto do público, que delira).

Produtos, poemas

Filmes profundos

Viva e deixe vender.

(Dança de forma cada vez mais sexual. Convida um homem a subir no palco, que recusa.)

(...)

A VOZ - A partir de agora se inicia a projeção do primeiro filme de Miopia.

(Inicia-se a projeção do primeiro filme de Miopia. Diotima tenta cantar e cospe sangue. O filme passa. Letreiros e imagens: A SÉTIMA ARTE. A REVOLUÇÃO. O PROGRESSO: XAMPU EXPRESSO: O SEU INGRESSO NO MUNDO DA ESTÉTICA PESSOAL. $)^{229}$

O filme "profundo" exibido era um comercial de xampu. A união entre mercadoria e lixo estrutura toda a encenação, com o aproveitamento da degradação do espaço e de dejetos na construção das dramaturgias da peça, e nesta cena está presente também na narrativa: a Garbage Shop é uma pequena empresa norte-americana que fornece filmes descartados, lixo, para o cinema de Miopia. Em uma cena anterior da peça (cena 16), já citada:

FAUSTO - Mackee. O que é que tem o Mackee?

BELMIRO - É muito simples. Ele conseguiu maioria com os acionistas da empresa para que liberem os filmes para a exibição no cinema.

FAUSTO - Filmes ou propagandas?

AUTÔMATO - O Mackee não é um produtor cultural, ele é apenas gerente de uma empresa de lixo em Chicago. Estes filmes são jogados fora pelas empresas e ele recolhe, para exportação ${ }^{230}$.

A mercadoria que surge ligada ao lixo é aqui a própria arte. A peça, em um

${ }^{229}$ ALMEIDA, Ligia Marina; DELMANTO, Ivan; FARIA, Fernanda, et al. Miopia. Inédito, 2006, p. 16. ${ }^{230}$ Idem, p. 13. 
procedimento de metalinguagem, é também colocada sob este esquadro e seria possível então compreender o sentido daquele grande outdoor luminoso colocado no alto da caixa d'água da Usina, que podia ser contemplado pelo público logo na primeira cena da peça:

\section{PRÓLOGO}

Um imenso outdoor: $2^{a}$ Trupe de Choque apresenta: Miopia. Teatro e crítica à mercadoria. Telefone para contato: 61173481. Preços promocionais.

O conteúdo do outdoor tinha a mesma diagramação do material de divulgação, cartazes, panfletos e anúncios de imprensa utilizado pelo grupo para anunciar a peça. Já mencionamos que nesse caso a própria peça surge então como mercadoria, participante dessa nova fase de valoração do capital em que a difusão social e cultural dos produtos é parte essencial à produção do valor. Mas há algo mais na presença do outdoor: realizado em uma estrutura de madeira tosca, em que as lâmpadas ficavam expostas, pendurado torto no alto da torre da caixa d'água da Usina, o outdoor relaciona a mercadoria e o lixo, produto e sua descartabilidade. A peça é anunciada sob a moldura do lixo, concretamente. O texto de Miopia, formado pelo material do teatro épico, é emoldurado, tratado e encenado com o lixo e como lixo. Deste atrito e desta explosão, surgem as ruínas testemunhadas e percorridas pelo público durante toda a peça.

Já em data anterior ao período tematizado na peça, 1921, em um de seus textos de juventude, Capitalismo como religião, Walter Benjamin relaciona a anestesia sem memória do cotidiano, geralmente ligada à alienação religiosa, com as práticas do capitalismo: a relação com o fetiche da mercadoria já era, para Benjamin, uma prática espetacular:

Capitalismo é uma religião de puro culto, sem dogma.

Metodologicamente, é preciso começar a investigar a ligação entre mito e dinheiro através do curso da história, a ponto do dinheiro desenhar muitos elementos do Cristianismo que são considerados parte de seu próprio mito. É preciso acrescentar ao nosso entendimento do capitalismo como religião que os primeiros pagãos não acreditavam na religião servindo a interesses morais mas sim como uma severa prática. Em outras palavras, a religião não alcança mais grande clareza sobre sua "ideal" ou "transcendental" natureza, graças às práticas do moderno capitalismo. Portanto também considerando os indivíduos sem religião ou os que têm outras crenças como membros de suas comunidades. No mesmo caminho da moderna burguesia que agora considera seus membros como não empregados lucrativamente. ${ }^{231}$ 
Benjamin vê nesse texto a religião do capitalismo como um conjunto de práticas, sem teoria ou dogma. Antecipando as posteriores teorias sobre a ideologia, como o conceito de espetáculo desenvolvido por Debord, este trecho liga sujeito e realidade, estrutura e superestrutura, ideologia e modo de produção, ao considerar como fundamental da crença no capitalismo não uma teologia ou conjunto de dogmas, mas os rituais cotidianos sempre ligados à acumulação de capital e aos feitiços da mercadoria, mesmo para as classes sociais que estão excluídas desta acumulação.

A tendência para o mutismo, que se pode perceber na forma labiríntica de Miopia, depende, para sua decifração, da definição de uma chave alegórica correta. Se esta afirmativa estiver correta, a seguir testaremos novamente essa chave, que tomará cada vez mais, salvo engano, as feições mutáveis do capitalismo tardio e de suas práticas espetaculares.

\section{V.2. Dramaturgias do espaço em Miopia: a forma labirinto, o espetáculo da cidade e o espelho}

Pouco conhecido fora da Polônia até há alguns anos, Bruno Schulz (1892-1942) é autor de dois únicos livros, misturas de contos e romances autobiográficos: Lojas de Canela (1934) e Sanatório (1937). No primeiro deles, há um conto, chamado Rua dos Crocodilos, em que, ao buscar definir a metrópole moderna, Schulz aborda aspectos que podem nos ajudar a ler também a encenação de Miopia.

Primeiro quando utiliza uma imagem sobre a impossibilidade de narrar, já que a metrópole contemporânea deixa de ser um livro legível para se transformar em catálogo de propagandas:

Tudo ali (na cidade) era igual na sua diferença, como nas fotografias de produtos e nos prospectos ilustrados. Esta semelhança era mais do que uma simples metáfora, porque às vezes, passeando na cidade, tinha-se a impressão de folhear um prospecto, seus enjoativos classificados comerciais, entre os quais fazem ninhos os parasitas dos anúncios suspeitos, as notas irritantes, as ilustrações duvidosas; e esses passeios eram tão estéreis e sem qualquer rendimento como as excitações da fantasia induzidas pelas páginas e colunas das publicações pornográficas. ${ }^{232}$

${ }^{231}$ BENJAMIN, Walter. Selected writings, vol.1 . London: Belknap Harvard, 2002, p. 288.

${ }^{232}$ SCHULZ, Bruno. Lojas de Canela. Rio de Janeiro: Imago, 1996, p. 94. 
Essa peregrinação exaustiva por páginas de propagandas, como se o público folheasse eternamente a experiência da desorientação e da angústia do sempre igual, surge no longo e labiríntico percurso durante a peça, mesmo percurso que o lixo percorria na Usina, que aos poucos transforma os passos do público, ao longo de uma história em que a linha de ação não aparece (como em uma revista de propagandas), em um caminho de degradação e mal estar, como se transitasse por um engarrafamento de produtos de embalagens vazias.

Há múltiplos sentidos em trânsito constante, já que falamos de:

Uma realidade fina como papel, e em todas as fendas mostra seu caráter imitativo, como os desenhos do sol na couraça de um crocodilo ou de um poema. Há momentos em que se tem a impressão de que apenas nesta pequena nesga à nossa frente tudo se compõe exemplarmente numa imagem de fotografia de paisagem metropolitana mas, quando achamos que apreendemos um único e total sentido, já nas margens esta mascarada improvisada relaxa e se dissolve e, incapaz de desempenhar por mais tempo um único papel, desmancha-se atrás de nós em gesso, lixo e estopa, na sucata de um teatro enorme e vazio. ${ }^{233}$

Esta realidade fina como papel, transparente e por isso capaz de ser preenchida pelos inúmeros olhares do público, tem assim diversos sentidos; é eco de várias vozes e caleidoscópio de várias imagens, e isto deveria aparecer obrigatoriamente na profusão e no inacabado das imagens da encenação, capaz de propiciar essa experiência de multiplicidade da degradação ao público, imerso na variação infinitesimal dos capitais das bolhas financeiras, da cidade publicidade e das guerras televisionadas e patrocinadas do mundo mercado. Bruno Schulz ainda parece falar sobre Miopia, a cidade dos sonhos:

Falamos sobre o caráter ilusório e imitativo desta cidade, porém o significado destas palavras é definitivo e determinado demais para resumir o caráter incompleto e indeciso da sua realidade. A nossa língua não possui termos que dosem o grau de realidade, que definam a sua densidade. Falando sem rodeios, a fatalidade desta cidade é que nada nela se realiza, nada chega a seu definitivo, todos os movimentos iniciados ficam suspensos no ar, todos os gestos se esgotam antes do tempo e não podem ultrapassar um certo ponto morto, definido por cada um que a contempla. Já tivemos a oportunidade de notar a grande opulência e dissipação - nas intenções, nos projetos e nas antecipações - que caracterizam esta cidade. Toda ela não é senão a fermentação dos desejos de uma exuberância precoce, e por isso exangue e vazia. Aqui, numa atmosfera de demasiada facilidade, brota qualquer desejo, qualquer tensão passageira incha e cresce numa excrescência bojuda e oca,

${ }^{233}$ Idem, p. 96. 
irrompe uma vegetação parda e leve de ervas daninhas, de papoulas peludas sem cor, uma vegetação feita de um tecido imponderável de sonho e haxixe. Sobre toda a cidade paira um fluido preguiçoso e devasso de pecado, e as casas, as lojas, os homens parecem, às vezes, um calafrio no seu corpo febril, uma pele arrepiada nos seus sonhos delirantes. Em nenhum outro lugar nos sentimos tão ameaçados pelas possibilidades como aqui, tão estremecidos pela proximidade da consumação, tão empalidecidos e paralisados pelo deleitoso assombro da destruição. ${ }^{234}$

A encenação, negando o texto, teve que inventar uma língua própria, múltipla e incompleta o suficiente para conseguir falar de uma cidade que se movimenta na expansão infinita do capital, de sua criação e destruição avassaladoras, uma língua que pudesse ser puro movimento de sentidos e de metáforas, capaz de falar do capital contemporâneo, realidade que é pura incompletude, ameaça de possibilidades e de destruição. Mas, como as dramaturgias do espetáculo não pertencem ao drama burguês e às suas peripécias: "ultrapassando um certo ponto de tensão, a enchente pára e recua, a atmosfera se apaga e desfloresce, as possibilidades murcham e desmancham-se no nada, e as papoulas de excitação, pardas e alucinadas, dissipam-se em cinzas. "235

Essa sensação de errância por algo que poderia acontecer e nunca acontecerá pertence à forma e ao conteúdo do espetáculo. O resultado é que "vamos errar entre os letreiros e nos enganar mil vezes. Vamos nos enredar em mal-entendidos, até que toda a nossa febre e excitação se evaporem num esforço vão, num caminhar inútil. "236

Esse caminhar inútil é o exaustivo percurso do público, dos personagens e da utopia. É o caminhar inútil de quem folheia as páginas de Miopia, cheias de infinitas imagens como se fossem anúncios publicitários, a cidade da mercadoria devorando-nos enquanto espera por uma decifração, sem poder esperar como a esfinge esperou por Édipo.

Se arte é forma, conteúdo sedimentado em forma sensível, podemos perceber a peça, em sua contradição entre texto e cena, como capaz de reproduzir e alegorizar a metrópole brasileira, arcaica e ultramoderna; um labirinto de imagens formando o panorama múltiplo e caótico da mercadoria descartável, da cidade - capital e da vida lixo.

Esta combinação ornitorrínquica também pode ser observada na tendência dada pela crescente imbricação entre trabalho material e imaterial, uma vez que se presencia,

\footnotetext{
${ }^{234}$ Idem, p. 98.

${ }^{235}$ Idem, p. 102

${ }^{236}$ Idem, p. 103.
} 
além da monumental precarização do trabalho, uma significativa expansão do trabalho dotado de maior dimensão intelectual, quer nas atividades industriais mais informatizadas, quer nas esferas compreendidas pelo setor de serviços ou nas comunicações, entre tantas outras. A produção da cultura passou a ser integrada à produção de mercadorias em geral, pois a concorrência entre as empresas passou a acontecer no plano da produção e veiculação de imagens, quando o capitalismo começou a se voltar para a importância do desenvolvimento de signos por meio do forte investimento em propaganda e publicidade, gerando mudanças na dinâmica da geração do valor.

O processo de valorização do capital passa a ocorrer através do trabalho abstrato em sua forma virtual, mediante a produção "desterritorializada" de informação. Tal processo se define pela emergência de atividades de coordenação, inovação e gestão que revolucionam a forma-empresa tradicional. Daí emergem, também, fatores estratégicos novos, como as atividades imateriais de pesquisa e desenvolvimento, da comunicação e do marketing, do design e da formação. Tudo isso ganha impulso a partir das novas tecnologias da informação, levando a uma transformação das bases materiais da acumulação até então aplicadas no interior do paradigma fordista. Todos os níveis da vida social, em alguma medida, são alcançados pelo deslocamento ou dissolução de fronteiras, raízes, centros decisórios, pontos de referência. As relações, os processos e as estruturas globais fazem com que tudo se movimente em direções conhecidas e desconhecidas, conexas e contraditórias. É assim que a desterritorialização aparece como um momento essencial da ultramodernidade, como se o mundo se mostrasse povoado de sucedâneos, simulacros, fetiches autonomizados, reificados, alheios ao cerne das coisas, isentos da tensão e aura do real.

Talvez seja possível perceber na forma teatral proposta por Miopia que este universo do tempo fora da história, do eterno presente ausente, e do espaço desterritorializado é, ao contrário do que aparenta, essencialmente histórico e limitado, produtor de um presente em contínua transformação e de espaços marcados por uma realidade específica. Se pudéssemos seguir as pegadas de Jean Baudrillard pelo labirinto, talvez descobríssemos, entre uma saída fechada e outra, que a estrutura repetitiva daquilo que ele denomina o simulacro (isto é, a reprodução de cópias que não têm original) caracteriza a produção mercantil do capitalismo de consumo e marca o mundo de Miopia, cheio de objetos em irrealidade e numa ausência que flutua livre do referente (o lugar antes ocupado pela natureza, pelas matérias-primas e pela produção 
primária, ou pelos originais da produção artesanal), completamente diverso de todo o experimentado em qualquer formação social anterior.

Se é este o caso, então deveríamos esperar que a repetição constituísse ainda um outro traço da situação contraditória da produção estética contemporânea, contra a qual tanto as estéticas modernas e ultramodernas como a cultura de massa não podem ser senão uma reação. Isso é, de fato, o que se dá e basta apenas invocar a postura ideológica tradicional de toda a teoria e prática modernizadoras para observar a ênfase estratégica na inovação e na novidade, a ruptura obrigatória com os estilos prévios, a pressão (geometricamente crescente com a cada vez mais rápida temporalidade da sociedade de consumo, com suas mudanças de estilo e de moda a cada ano ou estação) para fazer o novo, produzir algo que resista e rompa com a força de gravidade da repetição, enquanto traço universal da equivalência mercantil, acaba-se, na produção em série do novo, caindo-se, de novo e ao fim do ciclo, na rede da mercadoria:

O moderno, o tempo do inferno. Os castigos do inferno são sempre o que há de mais novo neste domínio. Não se trata do fato de que acontece sempre o mesmo, e nem se deve falar aqui do eterno retorno. Antes, trata-se do fato de que o rosto do mundo nunca muda justamente naquilo que é o mais novo, de forma que este mais novo permanece sempre o mesmo em todas as suas partes. $-\mathrm{E}$ isto que constitui a eternidade do inferno. Determinar a totalidade dos traços em que se manifesta o moderno significaria representar o inferno. $^{237}$

Salvo engano, a estrutura espelhada da Usina de Lixo (em que um espaço espelha outro, arquitetonicamente, em que máquina espelha máquina) refletiria assim a estrutura espelhada do inferno enquanto simulacro: contraponto de diversos narradores, história que narra a imagem e o seu reflexo especular, a mercadoria. Seguindo este labirinto de espelhos, há na estrutura da peça a Colmeia das Imagens (um cinema só de comerciais) e a Colmeia da Memória (um foco de resistência política fracassada). É como se cada momento fosse encenado com o seu duplo contraditório.

\section{A COLMEIA DA MEMÓRIA}

CONTRA-REGRAS DE FAUSTO - Por favor, vamos logo que o Dr. Fausto está com pressa. Por favor, vamos fazer uma filmagem externa, por favor. O senhor não.

JOHANSEN - Eu não posso entrar?

CONTRA-REGRA - O senhor não pode.

\footnotetext{
${ }^{237}$ BENJAMIN, Walter. As Passagens. Belo Horizonte: Ed. UFMG; São Paulo: Imprensa Oficial do
} Estado de São Paulo, 2006, p. 586. 
JOHANSEN - Eu sou o lixo, não é? Eu sou a testemunha. Vocês não me querem. Mas eu sobrevivo. Eu volto. Para buscar as migalhas desta história. Eu rastejo. Eu vomito. O meu vômito é a sopa de letrinhas que vai contar esta história de todos vocês.

CONTRA-REGRA - Por favor, vamos logo, pessoal: o Dr. Fausto vai ficar nervoso.

(Operários do cinema recolhem sucata no esgoto das imagens. Fausto filma um documentário.)

FAUSTO - Esta cidade está podre. Eu vou contar: tem gente que ganha com as imagens, criando desejos e pervertendo a mente das pessoas. Desejos avassaladores, dentes de tubarão devorando as massas. Há uma aliança entre judeus e comunistas ricos, grandes empresários exploradores que desejam com o cinema de propagandas fazer uma lavagem cerebral nas mentes de todos, verdadeira lobotomia, preparando o domínio da devassidão. A partir de agora, eu vou contar a história definitiva desta cidade. Porque eu quero salvar a minha Miopia deste cinema podre! Eu quero um cinema puro!

CORO - (Numa saudação fascista.) Por um cinema puro! Por um cinema puro!

GLÉGUER - Meu nome é Gléguer Arouca, 17 anos. Trabalho faz dois anos no cinema.

FAUSTO - (Gravando.) E qual a importância da Colmeia da memória para os trabalhadores sofridos do cinema?

GLÉGUER - Tem uma importância muito grande, com certeza. Todos os trabalhadores do cinema gostaram da ideia de aprender a escrever histórias, né? Comigo não foi diferente.

FAUSTO - E o que vocês fazem aqui?

GLÉGUER - A gente recolhe do lixo os restos de filmes que não vão ser utilizados. E com as imagens que a gente recorta, a gente faz novas histórias. Eu no momento estou fazendo a história de um guerreiro excluído, como a gente diz.

FAUSTO - Vocês construíram uma Colmeia ao lado da Colmeia maior, o cinema. Fale sobre a relação de vocês com o cinema.

GLÉGUER - A relação é boa, né... a gente trabalha no cinema, é registrado.

FAUSTO - Faça alguma crítica ao cinema.

GLÉGUER - Crítica?

FAUSTO - Alguma coisa negativa do cinema. São tantas. O cinema só passa propaganda e isso faz com que as pessoas só pensem em consumir e consumir. Vocês querem acabar com o cinema de comerciais, não é? Este cinema que só existe atualmente para favorecer alguns empresários gananciosos, como o senhor Belmiro Ilitch. A cidade se transformou numa enorme cloaca, numa enorme propaganda. $\mathrm{E}$ a cidade não quer isso. A cidade quer um cinema que exiba filmes de verdade! Filmes como este que a Fausto Filmes está realizando!

JINGLE - Fausto Filmes!

Não seja falso

Cinema de verdade

É Fausto. (100\% Nacional!)

GLÉGUER-É, com certeza. A empresa do senhor é muito séria... 
FAUSTO - A única produtora de cinema 100\% nacional! E mesmo assim, não temos espaço no cinema de Miopia.

GLÉGUER - Então... Mas todo mundo aqui vai no cinema sim senhor.

(...)

MÉRCIA - Esta é a Colmeia da Memória.

Aqui construímos o nosso passado.

Aqui tecemos, nos fios da memória que melhor enxerga,

Porque enxerga a História vista de baixo,

Nossas histórias. Recriando a partir do lixo

Recriando a partir do material tóxico das imagens vendidas

Usadas e destruídas

Nossas histórias.

Uma imagem não é só uma imagem

Uma imagem pode ser uma flor, um estigma, uma tatuagem, uma ferida

Uma mercadoria,

E uma imagem pode ser também um pedaço de História.

Recortamos e colamos fragmentos de um discurso absoluto

Para formar correntezas contraditórias, veredas até o passado

Recontamos histórias dos tempos em que a cidade era feita de utopia

Revivemos fatos, pessoas, sonhos há muito esquecidos e oprimidos Aprendemos a ler e a escrever com o massacre

Através de imagens recortadas os trabalhadores construíram sequências de histórias.

Através de letras recortadas, há frases por todos os cantos, há pedaços de velhos discursos de sonho. ${ }^{238}$

Dentro da narrativa de Miopia, a colmeia da memória é uma ONG, fundada por Mércia Alberico, a arquiteta que projetara o cinema de comerciais de Miopia. Enojada com a estrutura opressora das relações de trabalho que envolviam o cinema, Mércia decide fundar uma organização capaz de dar apoio e formação aos trabalhadores do cinema. A cena revela, contudo, que o trabalho educativo da ONG é insuficiente para promover um movimento crítico e político em busca de melhores condições de trabalho:

FAUSTO - Vocês construíram uma Colmeia ao lado da Colmeia maior, o cinema. Fale sobre a relação de vocês com o cinema.

GLÉGUER - A relação é boa, né... a gente trabalha no cinema, é registrado $^{239}$.

${ }^{238}$ ALMEIDA, Ligia Marina; DELMANTO, Ivan; FARIA, Fernanda, et al. Miopia. Inédito, 2006, p. 2930.

${ }^{239}$ ALMEIDA, Ligia Marina; DELMANTO, Ivan; FARIA, Fernanda, et al.op. cit. , p. 30. 
A Colmeia da Memória surge como uma autocrítica empreendida pelo grupo em relação ao trabalho artístico-pedagógico realizado na Usina, com as oficinas peripatéticas. Naquele momento interessava problematizar a utilidade de tal trabalho, já que as oficinas contaram com muitos participantes que, ao final do processo, voltaram às suas "vidas danificadas" de sempre. Após a realização de inúmeras reuniões artísticopedagógicas, o grupo concluíra que provavelmente as oficinas haviam contribuído mais para o processo artístico de Miopia do que para o processo emancipatório dos participantes. Muitas das histórias e cenas improvisadas durante as oficinas serviram como material de pesquisa para o processo criativo. Alguns dos participantes das oficinas incorporaram-se ao grupo, participando da iluminação, da montagem técnica e do elenco de atores. Mas o objetivo educacional daquele espaço peripatético parecia não ter sido atingido:

Primeira coisa: não realizar mais oficinas. Pensar em um espaço de formação conjunta e continuada, em um espaço de pesquisa. Devemos realizar Núcleos peripatéticos de pesquisa. Como objetivo artístico/pedagógico dos núcleos peripatéticos é importante definir o que pretendemos: a emancipação por meio de uma prática artístico-pedagógica.

Ao contrário dos parâmetros da pedagogia formal, baseados no desenvolvimento progressivo e linear de seus alunos a partir de conhecimentos administrados pelo professor tradicional, deveríamos adotar como metodologia a instauração de processos criativos. Sob tal pedagogia, o participante não necessita da aquisição prévia de conhecimentos, técnicas ou habilidades mas, através da experiência criativa, baseada na pesquisa cotidiana, ou seja, na formulação constante de perguntas, ao ver-se diante das questões, lacunas e vazios instaurados pelo próprio processo de criação coletiva poderá construir, conduzido e apoiado pelos coordenadores dos núcleos, o conhecimento necessário para expressar-se artisticamente. É importante ressaltar que não devemos falar de qualquer processo criativo, mas sim de uma investigação do processo criativo como prática coletiva emancipatória. ${ }^{240}$

A cena da Colmeia da Memória foi das últimas a serem criadas e foi escrita após o penoso processo de avaliação e reflexão que o grupo realizou a partir da experiência com as oficinas. Deixar de lado a nomenclatura e a estrutura das oficinas representaria a realização de núcleos de pesquisa: estes teriam como objetivo artístico-pedagógico $a$

${ }^{240}$ DELMANTO, Ivan. Ata de reunião artístico-pedagógica. In: ALMEIDA, Ligia Marina; FARIA, Fernanda; DELMANTO, Ivan, et al. Anjos do desespero. Relatório da terceira etapa de pesquisa. Apresentado à Secretaria de Cultura do Município de São Paulo. Inédito, 2006, p. 122. Disponível para consulta na Divisão de Fomento da Secretaria Municipal de Cultura. 
prática cotidiana da emancipação. Assim, a emancipação não seria uma utopia longínqua, a ser perseguida em devaneios, mas formada por práticas constantes de ação e reflexão sobre o fazer artístico, em infinito processo de investigação e descoberta.

Este processo de emancipação envolveria a produção de processos de subjetivação dos participantes em seus coletivos. Foi importante para nós naquele momento a referência do filósofo francês Félix Guattari, para quem há no momento histórico presente um processo de dessubjetivação individual e social: à arte, à filosofia e à educação caberiam a tarefa de produzir novas subjetividades, ou seja, de dotar o ser humano de uma nova capacidade de ser sujeito de seus próprios atos e processos.

\begin{abstract}
Não se trata simplesmente, portanto, de uma remodelagem da subjetividade, mas de uma produção sui generis. O que importa aqui não é unicamente o confronto com uma nova matéria de expressão, é a constituição de complexos de subjetivação: indivíduo/grupo/trocas múltiplas, que oferecem à pessoa possibilidades diversificadas de recompor uma corporeidade existencial, de sair de seus impasses repetitivos e, de alguma forma, de se re-singularizar. (...) A cada um desses componentes corresponde uma prática necessária. Em outros termos, não se está mais diante de uma subjetividade dada como um em si, mas face a processos de autonomização, ou de autopoiese. ${ }^{241}$
\end{abstract}

Esses processos de autopoiese múltiplos, de autoconstrução por meio de uma poética de si (dar novas formas à própria sensibilidade e, por consequência à relação de si próprio com o mundo), seriam possíveis através da constituição de complexos de subjetividade, isto é, de uma constelação de práticas capazes de recuperar a capacidade de compreender e de agir sobre o mundo e sobre si.

Guattari considera como subjetividade o conjunto das condições que torna possível que instâncias individuais e/ou coletivas estejam em posição de emergir como território existencial, capazes de estabelecer relações de alteridade, tornando o outro próximo. Segundo Guattari, a importância da arte para a invenção destas novas subjetividades residiria em que:

É evidente que a arte não detém o monopólio da criação, mas ela leva ao ponto extremo uma capacidade de invenção de coordenadas mutantes, de engendramento de qualidades de ser inéditas, jamais vistas, jamais pensadas. O limiar decisivo de constituição desse novo paradigma estético reside na aptidão desses processos de criação para se autoafirmar como fonte existencial, como máquina

${ }^{241}$ GUATTARI, Félix. Caosmose. São Paulo: Ed. 34, 2003, p. 16-18. 
auto-poética. ${ }^{242}$

A investigação constante de práticas emancipatórias como objetivo central dos núcleos buscaria instaurar novas formas de convivência coletivas, territórios de aprendizado e de transformação mútuas. Assim, o objetivo de produzir novas subjetividades, gerando processos de emancipação, não é realizado através de um processo externo às ações artísticas e pedagógicas dos Núcleos, mas sim seria concretizado na apropriação dos meios e dos modos de produção do discurso poético por parte dos coletivos participantes. Entendíamos por essa coletivização dos meios e dos modos de produção a realização de um processo artístico de criação em que todos os participantes tivessem participação ativa e consciente em todas as práticas, conceitos, procedimentos e escolhas relacionadas ao discurso poético produzido coletivamente.

definição (em rotação) de meios e de modos de produção: na acepção clássica da sociologia, os meios de produção são os objetos ou matérias-primas sobre os quais se trabalha e o conjunto material que se interpõe entre o trabalhador e este objeto, ou seja, o conjunto de ferramentas, técnicas, habilidades e condições concretas com as quais este trabalhador deve lidar para agir sobre o objeto. O modo de produção envolve todas as relações que se estabelecem entre os diversos trabalhadores na construção de um objeto específico. Para que haja uma apropriação dos meios e dos modos de produção por parte de todos os envolvidos no processo de produção, tais relações precisam ser conscientemente investigadas, testadas, construídas e coletivizadas. ${ }^{243}$

É importante para a leitura da cena sobre a Colmeia da Memória saber que a sua criação deu-se em um momento de realização de uma rigorosa autocrítica do grupo: a cena expõe assim as entranhas do processo de criação vivido, já que as oficinas foram parte importante de tal processo, envolvendo o grupo todo na elaboração e na coordenação dos encontros artístico-pedagógicos. Optei por expor acima o que o grupo concluiu desta avaliação, a partir da ata da última destas reuniões críticas, porque me parece importante perceber que naquele momento havíamos formulado, inclusive, novas metodologias de prática artístico-pedagógica. Durante o processo de criação de Miopia, encontramo-nos frustrados com os rumos tomados até então, principalmente na relação que o grupo estabeleceu com os habitantes da Usina e do seu entorno, e já projetávamos

\footnotetext{
242 Idem, p. 135.

243 DELMANTO, Ivan. Ata de reunião artístico-pedagógica. In: ALMEIDA, Ligia Marina; FARIA, Fernanda; DELMANTO, Ivan, et al. Anjos do desespero. Relatório da terceira etapa de pesquisa. Apresentado à Secretaria de Cultura do Município de São Paulo. Inédito, 2006, p. 123. Disponível para consulta na Divisão de Fomento da Secretaria Municipal de Cultura.
} 
novos rumos. Esta ansiedade gerara a crítica impiedosa, e o tom de deboche, em relação ao projeto educativo de Mércia. De maneira geral, considerávamos as oficinas muito técnicas, preocupadas em ensinar um ofício, fosse de atuação, de música ou de direção teatral, e por isso a formulação de um programa pedagógico capaz de instaurar processos criativos. É o contrário da proposta da Colmeia da Memória:

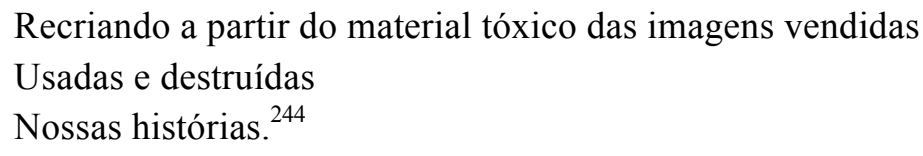

Há nesta proposta, e havia na prática das oficinas peripatéticas, uma espécie de idealização da experiência "dos pobres e desfiliados", como se a sua rememoração e posterior materialização artística fosse suficiente em um processo pedagógico. Como a cena procurava promover um acerto de contas com essa experiência, a encenação assumiu um caráter de dilaceramento: a cena ocorria sob o grande tubo de dilaceramento do lixo, espelhando o local em que as cenas do cinema eram realizadas. Este processo de destruir o lixo do próprio grupo era realizado na própria cena: o cenário era formado apenas por uma pintura dourada, que simulava uma colmeia. Diversos objetos retirados do tecido urbano, cones de sinalização, placas, postes e lixo generalizado estavam expostos simulando as obras artísticas produzidas pelos trabalhadores do cinema e pelos participantes das oficinas. Em uma ação sem aparente conexão com o que estava sendo dito pelo texto, os atores destruíam minuciosamente todo o cenário da cena, raspando inclusive a tinta dourada da Colmeia. O panorama final da cena era de desolação, contrastando com o monólogo otimista de Mércia.

Cabe ainda observar que a cena criada após estas reflexões pedagógicas é uma cena de destruição e de desolação: a clareza das novas propostas artístico-pedagógicas surgidas já naquele momento não foi suficiente para se transformar em cena. Ou o grupo ainda não acreditava que aquelas formulações sobre emancipação fossem passíveis de realização.

Os elementos retirados da cidade, presentes na cena da colmeia, aparecem em toda a encenação da peça. O espaço amplo da Usina sugeria a utilização da linguagem urbana, representada por sons e elementos cênicos (como os cones de trânsito e a fita de

244 ALMEIDA, Ligia Marina; DELMANTO, Ivan; FARIA, Fernanda, et al. Miopia. Inédito, 2006, p. 30 . 
isolamento) recriados e apresentados como degradação, como ruína, como lixo. A linguagem da cidade, que é a linguagem da mercadoria, surge como formadora de uma paisagem de destroços.

Já mencionamos a presença dos autômatos na peça, como uma classe morta. Os bonecos também estavam presentes em toda a encenação: como personagens e como duplos dos próprios atores, seguindo esta narrativa espelhada em que a imagem contradiz e esconde a sua origem, realidade obscura. $\mathrm{O}$ autômato, que surge em todos os momentos da peça, em cada canto da usina, pode ser visto em Miopia como alegoria da mercadoria e do trabalho estranhado, realidade escondida, como ratos, pelo encanto das imagens. Mais do que os personagens principais, os autômatos, transformados em trabalhadores e em mercadorias, constituem a verdadeira engrenagem que movimenta a fábula.

A imagem do labirinto é a alegoria central do espetáculo. O labirinto surge no texto como conteúdo da fábula, quando os personagens se debatem diversas vezes buscando saída para diferentes labirintos presentes na cidade, e como forma, quando as cenas são contadas ora com unidade temporal ora de forma fragmentada, constituindo diversos caminhos, cheios de idas e vindas, sem que haja uma única saída para a leitura da peça. Os personagens naufragam em Miopia, perecendo sem saída nos corredores da utopia que eles próprios construíram, sem que nenhum atinja a meta estabelecida. Este aspecto é ampliado no plano da encenação: há imagens que se repetem, pistas que não levam a uma única resposta, imagens à espera de decifração. O público percorre um trajeto de múltiplas direções, em que não se sabe nunca o que acontecerá no próximo passo dado. De certa forma, o labirinto é aqui, além de alegoria da vida danificada sobre os escombros do capitalismo tardio, imagem do próprio teatro.

A mais surpreendente manifestação desse processo infernal da repetição pode ser observada em nossa recepção da música pop contemporânea de qualquer tipo - os vários tipos de pagode, rock, sertanejo, blues ou "black". Como Jameson já escreveu, jamais ouve-se uma das peças produzidas nesses gêneros pela primeira vez; ao contrário, vive-se em uma constante exposição a eles, em todo tipo de diferentes situações, desde a batida renitente no rádio do carro aos sons no almoço, no local de trabalho, em shopping centers, até aquelas performances aparentemente completas da "obra" em um clube noturno ou em um estádio de futebol, ou nos CDs comprados e levados para serem ouvidos em casa. A devoção apaixonada que se pode criar a essa ou aquela música pop, o rico investimento pessoal de todo tipo de associações particulares 
e simbolismo existencial, característico de tal devoção, são integralmente uma função da obra em si: a música pop, por meio da repetição, torna-se insensivelmente parte do tecido existencial das próprias vidas dos ouvintes, de tal modo que aquilo que se ouve é a si mesmo, em suas próprias audições prévias. É este o caso de duas músicas compostas como jingle/leitmotiv de um dos personagens da peça, Maribel: criada pelos atores, a música aparece em diversos momentos do labirinto. Quando a música é repetida infinitamente, como se pelos ecos da indústria cultural, como num castigo infernal, e são incorporadas à peça as suas inúmeras versões (versões acústicas, ao vivo, toque de celular), os seus sentidos iniciais são reconfigurados: se o objeto música desaparece sob a sedimentação da cultura de massa e o que se ouve em cada canção são os próprios desejos e lembranças, torna audíveis ecos encobertos da subjetividade submetida aos imperativos das leis absolutas de mercado, capazes que são, em sua violência inerente, de transformar um sentido em outro e em outro, sucessivamente. Se a música desaparece no simulacro, o reflexo do divíduo aparece, como simulacro, labirinto de espelhos.

A imagem do espelho surge concretamente na cena em que Maribel, em frente a uma vitrine, contempla o próprio reflexo e sonha em moldar o próprio corpo deformado para reproduzir a beleza harmônica e morta dos bonecos à venda na loja:

\section{VITRINE, CLAREIRA DOS PREÇOS}

Dois homens entram trazendo sacos de lixo com rádios, jogados na rua. Uma mulher limpa a vitrine. Belmiro traz um autômato músico e o autômato da cantora Diotima e os deixa na vitrine.

AUTÔMATO - Venham ouvir rádio. Venham ouvir rádio.

DIOTIMA - (Canta.) Uma grande calma me escuta quando escuto suas almas e lamúrios

Mudas as bocas falam-me das tardes e do mundo e só eu entendo sua língua

Seu sono, seu som e sua fúria:

Ouço os cabelos e pelos crescerem na sombra e no silêncio, como a grama,

E a lua branca branca espelha cada rosto adormecido

Mas chamas, eu sei, habitam o interior de cada corpo inanimado

À espera da vida chamada preço.

Maribel contempla a vitrine da loja de Belmiro, fascinada pelos bonecos.

MARIBEL - Qual é a minha sombra? Qual é o meu gosto?

Qual é o meu rosto? Qual é o meu preço?

Meu corpo é um labirinto, emaranhado

De linhas tortas que me torturam 
Ao meu corpo estou atada.

Só me vejo sem rosto e sem vida

Escondida

No canto escuro dos derrotados.

Eu posso ver nos seus corpos meus dejetos e meus desejos

Gravados como tatuagem

$\mathrm{Na}$ vida que mora em vocês

Habitando cada ruga ausente, cada preço presente ${ }^{245}$.

O primeiro aspecto que podemos observar na cena é o da duplicidade: autômatos e corpo humano, corpo humano e seu reflexo. O autômato de Diotima, figura que na peça fora uma famosa cantora do rádio, canta como se fosse a própria voz de Maribel. Ter o corpo dos bonecos que são vendidos pelo empresário Belmiro e ter a própria voz colonizada pelo canto de Diotima representam a ocupação do sujeito pelas imagens e mercadorias da indústria cultural. $\mathrm{O}$ sujeito tradicional da narrativa teatral, aquele que tem objetivos e age, é aqui "assujeitado" por uma voz e por uma imagem que não lhe pertencem e que o oprimem como objetos de desejo de consumo. A vida gravada como tatuagem está nos bonecos, nos seus preços, e não em Maribel, o personagem que teoricamente deveria agir.

A comparação com uma cena clássica do repertório do teatro épico, presente na peça $A$ resistível ascensão de Arturo $U i$, de Brecht, pode nos esclarecer sobre alguns deslocamentos formais:

(De frente a um grande espelho de alfaiate Ui continua sozinho.) Aqui estou com a vênia de Brutus (pois Brutus é um homem honrado, como são todos eles, todos homens honrados) junto ao defunto para lhes falar. Ele foi meu amigo, foi justo e leal a mim. Mas Brutus nos diz, César era tirânico. E Brutus é um homem honrado. Ele trouxe muitos cativos a Roma: os cofres de Roma se encheram com os resgates. Talvez isso já fosse tirania de César? Decerto, se o homem pobre de Roma dissesse isso dele, César teria chorado. Seriam os tiranos de substância mais dura? Talvez! Mas Brutus nos diz que César era tirânico. E Brutus é um homem honrado. ${ }^{246}$

Além do monólogo dito também em frente ao espelho, é importante ressaltar o diálogo que Brecht promove com a tradição clássica, ao reproduzir - no contexto das lições ministradas por um ator canastrão a um mafioso interessado na sedução política (Arturo Ui) -, o célebre discurso de Marco Antônio em Júlio César, de Shakespeare. As

\footnotetext{
245 ALMEIDA, Ligia Marina; DELMANTO, Ivan; FARIA, Fernanda, et al. Miopia. Inédito, 2006, p. 17.

${ }^{246}$ BRECHT, Bertolt. Teatro Completo, vol. 8. São Paulo: Paz e Terra, 1992, p. 165.
} 
intenções de Ui são bastante explícitas: proferir a pérola de oratória em frente ao espelho significa um treinamento de ator para que consiga seduzir "as pessoas simples". A contratação de um ator "shakespeariano" por um mafioso não deixa de tematizar a função da arte na indústria cultural nascente. Os trejeitos tradicionais do ator dramático servem aqui aos interesses da manipulação. É a condenação, realizada por Brecht, do ator dramático, revelando os aspectos ideológicos desta forma teatral. Há ainda, na preocupação com a imagem do gângster uma clara relação com a espetacularização do terreno político, bastante explorada pelo nazismo. É possível identificar assim, na relação de Ui com o espelho, a expressão tanto da indústria cultural quanto da exposição do discurso político como mercadoria, aspectos da sociedade do espetáculo. No entanto, os interesses de Ui são bastante materiais: ele pretende tomar o poder controlando o cartel da couve-flor. A disputa de Ui é pelo controle da mercadoria e tal necessidade, ele precisa derrotar seus concorrentes ou será derrotado, o escraviza e o faz tomar atitudes violentas. $\mathrm{O}$ ator que $\mathrm{Ui}$ reproduz, funciona aqui como o seu próprio reflexo, só que um reflexo em uma posição contrária mas igualmente dependente, a de trabalhador. Ui descobre no seu reflexo, no seu Outro representado pelo ator, que sua existência como capitalista não se realiza se o outro não for forçado a vender-se a si mesmo voluntariamente. Isso nos faz lembrar uma importante descoberta de Marx, sobre a teoria moderna da colonização: "descobriu que o capital não é uma coisa, mas uma relação social entre pessoas, efetivada através de coisas. "247

A relação social entre pessoas, efetivada através de coisas, é representada na relação entre Ui e o ator, aqui mediada pelo dinheiro, pela contratação do ator e, em um plano mais alegórico, pelo espelho.

Tempos depois, quando Guy Debord escreve o seu $A$ sociedade do espetáculo, à luz de novas manifestações do capitalismo, a descoberta de Marx é reescrita: “o espetáculo não é um conjunto de imagens, mas uma relação social entre pessoas, mediada por imagens.

A reescritura promovida por Debord condensa muitas das transformações que marcam o percurso entre as relações sociais descritas por Brecht e as relações sociais expressas em Miopia. O confronto entre os dois espelhamentos, o de Ui e de Maribel, e o de Marx e Debord, marca transformações do teatro épico e da realidade capitalista que o inspira, realidade esta baseada na ascensão da imagem como mercadoria

\footnotetext{
${ }^{247}$ MARX, Karl. O Capital, livro I, vol. 2. Rio de Janeiro: Civilização Brasileira, 1999, p. 882.

${ }^{248}$ DEBORD, Guy. A sociedade do espetáculo. Rio de Janeiro: Contraponto, 1997, p. 14.
} 
predominante e como estratégia de geração de valor.

Segundo Guy Debord, tal sociedade não é apenas uma sociedade mediada por imagens mas uma sociedade que contempla a si mesma, que se vê nas imagens que produz como um sujeito automático, incapaz de agir e controlar seu destino. Como Maribel que vê o sujeito automático do boneco morto-vivo de Diotima agindo e cantando por ela, guiando seus impulsos e seus desejos.

Enquanto contemplava e dizia seu texto, após ouvir o seu canto na voz de Diotima, a ação de Maribel era puro sofrimento. A atriz executava a contemplação a partir de inúmeras torções do corpo, descobertas em uma investigação do método de treinamento de Meyerhold. A imagem trabalhada foi a da imagem dos bonecos e de seu próprio reflexo sendo capaz de perfurar o corpo da personagem. Em semelhança à descrição do 11 de setembro, realizada por Eugênio Bucci.

Para Bucci, no lugar das duas torres, irrompeu o vazio. O ato terrorista de 11 de setembro descosturou a paisagem e, mais ainda, abriu um rasgo na linguagem, esgarçou a ideologia, deixando ver o lado escuro do avesso do cenário. $\mathrm{O}$ ato terrorista teria interferido na instância do olhar, que conectaria a sociedade consigo mesma, e, assim, conseguiria o inacreditável: ferir o corpo de cada um, tanto daqueles a quem pôde matar sob os escombros dos edifícios como daqueles a quem, na forma de um show, alcançou como imagem.

Duvidar dos próprios olhos teria marcado o contato com o trauma: ainda segundo Bucci, a exemplo do mutilado de guerra que tenta mover um músculo que já não possui, o mutilado do olhar tenta acionar um ícone, carregado de sentido imaginário, e se dá conta de que esse ícone já não existe - e seu sentido imaginário virou poeira negra, fumaça, carnificina. Se Arturo Ui representa as mutilações das relações sociais mediadas por coisas, Maribel representa a mutilação do olhar, pelo desejo e pela imagem.

Seguindo este caminho, talvez seja possível afirmar que a intensa atividade de produção de imagem que se seguiu ao 11 de setembro, que se daria na instância do olhar e que obedeceria à lógica do desejo inconsciente, seria uma intensa atividade de produção industrial. Mais que isso, seria uma atividade que se põe como um modo de produção. O espetáculo é um modo de produção. É possível perceber na comparação dos espelhos utilizados por Ui e por Maribel não apenas a tirania de relações sociais exclusivamente voltadas à produção e à circulação de mercadorias. Se não estivermos errados, o que a transição de Ui a Maribel nos revela é um regime voltado à produção 
da imagem: da imagem da mercadoria e da imagem como mercadoria. O culto à mercadoria - já presente no espelho de Ui e que já constituía então um fator de barbárie e que apenas se intensificou ao longo do século XX - teria assim desaguado no culto à imagem da mercadoria, o que teria permitido o destravamento do princípio de acumulação e reprodução do capital, lançando ambos a uma escala jamais vista.

A natureza do capitalismo e do capital foi alterada a partir do final da Segunda Guerra. Em 1967, Guy Debord, apontava: “O espetáculo é o capital em tal grau de acumulação que se torna imagem." Ele dizia mais: “O capital já não é o centro invisível que dirige o modo de produção: sua acumulação o estende até a periferia sob a forma de objetos sensíveis. Toda a extensão da sociedade é o seu retrato." No imaginário contemporâneo, os signos que se apresentam como objetos-mercadorias para promover a completude imaginária do sujeito tornam visível o próprio capital - e monopolizam o campo do visível. Não há, portanto, uma descontinuidade entre a tirania da mercadoria sobre o sujeito e a tirania da imagem (da mercadoria e como mercadoria) sobre o sujeito, entre o espelho de Ui e o espelho de Maribel. Ao contrário: a imagem é o prolongamento exponenciado do predomínio da mercadoria sobre a vida social. Tanto que, para Debord, “o espetáculo é o momento em que a mercadoria ocupou totalmente a vida social. Não apenas a relação com a mercadoria é visível, mas não se consegue ver nada além dela: o mundo que se vê é o seu mundo". Ou por outra: "O consumidor real torna-se consumidor de ilusões. A mercadoria é essa ilusão efetivamente real, e o espetáculo é sua manifestação geral."

Maribel quando contempla, concentrada em imagem, ou renascida na imagem de si mesma, é a mercadoria (ou simplesmente a imagem, pois uma e outra se indiferenciam), é a correspondência, no olhar, do sentido que o sujeito procura para si mesmo: ocupar o objeto que fornece a completude imaginária do sujeito. Sendo modo de produção, o espetáculo, no entender de Debord, é o que unifica e dá um patamar ao capitalismo. Aí, ainda que Debord não o diga com todas as letras, o desejo inconsciente flui nas veias da produção e do consumo da imagem; o capitalismo passa a parasitar as teias do desejo e ambos os processos se tornam mais selvagens do que jamais foram. $\mathrm{Na}$ cena, Maribel se detém diante de uma vitrine, para contemplar os autômatos produzidos pela empresa de Belmiro expostos como mercadoria de luxo. O que Maribel contempla, no seu reflexo produzido pela superfície lisa da vitrine, é o seu desejo marcado pelo consumo, na imagem da mercadoria confundida com a sua própria imagem refletida.

Por fim, há um conto de Borges, presente no Livro dos seres imaginários, que 
pode nos ajudar a compreender Maribel enquanto esta contempla o espelho:

Segundo Giles, a crença no Peixe é parte de um mito mais amplo, que se refere à época legendária do Imperador Amarelo.

Naquele tempo, o mundo dos espelhos e o mundo dos homens não estavam, como agora, incomunicáveis. Eram, além disso, muito diferentes; não coincidiam nem os seres nem as cores nem as formas. Ambos os reinos, o especular e o humano, viviam em paz; entrava-se e saía-se pelos espelhos. Uma noite, a gente do espelho invadiu a Terra. Sua força era grande, porém ao cabo de sangrentas batalhas as artes mágicas do Imperador Amarelo prevaleceram. Este rechaçou os invasores, encarcerou-os nos espelhos e lhes impôs a tarefa de repetir, como numa espécie de sonho, todos os atos dos homens. Privou-os de sua força e figura e reduziu-os a meros reflexos servis. Um dia, entretanto, livrar-se-ão dessa mágica letargia.

O primeiro a despertar será o Peixe. No fundo do espelho perceberemos uma linha muito tênue, e a cor dessa linha não se parecerá com nenhuma outra. Depois, irão despertando as outras formas. Aos poucos diferirão de nós, aos poucos deixarão de nos imitar. Romperão as barreiras de vidro ou de metal e desta vez não serão vencidas. Junto às criaturas dos espelhos combaterão as criaturas da água.

No Yunnan não se fala do Peixe e sim do Tigre do Espelho. Outros acreditam que antes da invasão ouviremos do fundo dos espelhos o rumor das armas. ${ }^{249}$

Para Jean-François Lyotard, esse conto condensa uma crítica ao sujeito moderno. A subjetividade pressupõe o reflexo, uma representação da experiência e de um eu que experimenta. Mas, através dessa representação, que depende da função sintetizadora dos conceitos, perde-se a "fluência original da intuição", a comunicação entre o mundo humano e o mundo especular. Para Lyotard, Borges imagina esses seres como forças, e essa barra entre a representação e o representado, como uma barreira; imagina que o Imperador, o Déspota em geral, só pode sustentar sua posição sob a condição de reprimir os monstros e mantê-los do outro lado do muro transparente. A existência do sujeito depende deste muro, da escravização dos "poderes fluidos e letais" reprimidos do outro lado, e da função de representá-los.

Maribel, torta e torturada em frente ao espelho, expressa talvez um novo sujeito, formado pela imagem despótica proposta por Borges/Lyotard mas também pelo seu reflexo, o sujeito escravizado pelo Peixe, pelas criaturas do espelho e da água que conseguiram atravessar a fronteira do indivíduo autônomo, cuja identidade do eu tinha que ser coercitivamente mantida em oposição às tendências centrífugas do impulso.

${ }^{249}$ BORGES, Jorge Luis. "Os animais dos espelhos". In: O Livro dos seres imaginários. São Paulo: Cia. das Letras, 2008, p. 26. 
Maribel é o sujeito do mínimo eu, da obediência ao impossível gozo perpétuo, do imperativo categórico do gozo, de uma sociedade que se contempla a si mesma como espetáculo e que quer consumir seus próprios reflexos e produtos em busca do maisgozar. Estas configurações do gozo mortífero, pesadelo que marca a sociedade contemporânea, têm o seu reflexo aprisionado na encenação de Miopia em que os pedaços, excrementos e dejetos destes divíduos em busca de gozo acompanham, como cães perdidos, o perambular esvaziado dos personagens.

\section{V.3. As dramaturgias da memória e a experiência de Miopia}

Ainda para continuarmos com Walter Benjamin, para o filósofo alemão o sujeito tradicional da experiência não existe mais. Benjamin procura situar em diversos momentos de sua obra exatamente a perda ou o declínio acentuado da experiência, experiência esta que sempre teria repousado sobre a possibilidade de uma tradição compartilhada por uma comunidade humana, tradição retomada e transformada, em cada geração, na continuidade de uma palavra transmitida de pai para filho. A experiência teria caracterizado algo que passava de geração para geração; algo maior que as pequenas experiências individuais particulares. O sentido da experiência, o fato a ser contado ao outro e a ser incorporado na memória privada ou coletiva, estaria abalado: não haveria mais nada a contar. A perda da experiência acarretaria assim um outro desaparecimento, o das formas tradicionais de narrativa, de narração, que tinham sua fonte nessa comunidade e nessa transmissibilidade. A esse respeito, parece-nos esclarecedor que Walter Benjamin inicie o ensaio Experiência e pobreza (1933) perguntando de forma perturbadora:

Quem encontra ainda pessoas que saibam contar histórias como elas devem ser contadas? Que moribundos dizem hoje palavras tão duráveis que possam ser transmitidas como um anel, de geração em geração? Quem é ajudado, hoje, por um provérbio oportuno? Quem tentará, sequer, lidar com a juventude invocando sua experiência? ${ }^{250}$.

Em Experiência e Pobreza, texto que complementa $O$ narrador, Benjamin insiste justamente nas mutações que a pobreza de experiência acarreta para as artes contemporâneas. Não se trataria mais de ajudar, reconfortar ou consolar os homens pelo

${ }^{250}$ Idem., p. 114. 
resgate de uma experiência que não existe mais, ou por antigas formas de se contar uma história. Contra uma estética da interioridade, da harmonia, da suavidade e da graça, Benjamin defende as provocações e a sobriedade áspera das vanguardas.

Está claro que as ações da experiência estão em baixa, e isso numa geração que entre 1914 e 1918 viveu uma das mais terríveis experiências da história (...) Na época, já se podia notar como os combatentes tinham voltado silenciosos do campo de batalha. Mais pobres em experiências comunicáveis, e não mais ricos. (...) Uma nova forma de miséria surgiu com esse monstruoso desenvolvimento da técnica, sobrepondo-se ao homem (...) Sim, é preferível confessar que essa pobreza de experiência não é mais privada, mas de toda humanidade. Surge assim uma nova barbárie. Barbárie? Sim. Respondemos afirmativamente para introduzir um conceito novo e positivo de barbárie. Pois o que resulta para o bárbaro dessa pobreza de experiência? Ela o impele a partir para a frente, a começar de novo, a contentar-se com pouco, a construir com pouco (...) Ficamos pobres. Abandonamos uma depois da outra todas as peças do patrimônio cultural. ${ }^{251}$

A perda da experiência, que sempre esteve relacionada não ao sujeito individual mas à comunidade e à possibilidade do narrar acontecimentos exemplares, não é para Benjamin motivo de lamentação. A experiência teria sido substituída pelo choque. $\mathrm{O}$ choque seria a vivência do habitante das grandes cidades, isolado em meio a uma multidão que ele não conhece e que não o reconhece. Em meio ao choque contínuo, tal habitante só seria capaz de perceber-se como uma reunião de ruínas incapazes de definir uma subjetividade unitária, como acúmulo de traumas que marcam o seu corpo dominado pelas máquinas e por trabalhos alienantes e opressores.

A partir da vivência cotidiana do choque, o narrador formula sua exigência; constata o fim da experiência e da narração tradicional, mas também esboça a ideia de uma outra narração, uma narração nas ruínas da narrativa, uma transmissão entre os cacos de uma tradição em migalhas, tentativa de reunir todos os choques e traumas que habitam o indivíduo moderno. O narrador não seria mais a figura do contador de histórias tradicional, seja o poeta épico seja o escritor realista, mas seria a figura do trapeiro, do catador de sucata e de lixo, essa personagem das grandes cidades modernas que recolhe os cacos, os restos, os detritos, movidos pela pobreza, certamente, mas também pelo desejo de não deixar nada se perder.

Esse narrador sucateiro não teria por objetivo recolher os grandes feitos. Deveria apanhar tudo aquilo deixado de lado como algo que sem significação, algo que parece

${ }^{251}$ Idem., p. 115. 
não ter importância nem sentido, algo com que a história oficial não sabe o que fazer. Já ressaltamos acima que durante o processo criativo de Miopia, o material inicial de criação depositou-se exatamente nesses restos do discurso histórico. Depositou-se sobre aquilo que não tinha nome, aqueles que não tinham nome, sobre aquilo que não deixara nenhum rastro, aquilo que fora tão bem apagado que mesmo a memória de sua existência não subsistia - aqueles que desapareceram tão por completo que ninguém lembrava de seus nomes. Acreditava-se, durante todo este processo, que os narradores de Miopia deveriam transmitir o que a tradição, oficial ou dominante, não recordava. Essa tarefa paradoxal consistia, então, na transmissão do inenarrável, numa fidelidade ao passado e aos mortos.

O que o grupo aos poucos percebeu, constatando a insuficiência das próprias cenas criadas para formalizar tal material, é que esta história não poderia ser o desenrolar tranquilo e linear de uma narrativa contínua, mas poderia desenvolver-se por meio dos restos e da decomposição da história de cada personagem-narrador.

Este personagem, recolhedor de restos, é a figura que desistiu de narrar. Tal figura seria representada por um dos narradores presentes em Miopia, Johansen. Podese presenciar tal aspecto do personagem em duas de suas aparições no espetáculo, tomadas aqui separadamente:

JOHANSEN (enquanto atrás do público coloca uma fita de isolamento) - Afastem-se! Eu sou tóxico! Eu caminho pelas ruas como um leproso. Eu cobro das pessoas o que me devem: vida, conforto, vitórias. Depois dos toques agudos do meu chifre, eu vou devagar pelos becos desertos, recolhendo as oferendas sem agradecer, cuspindo no que posso cuspir. (...)

DIOTIMA - Eu sou uma autômata! Uma boneca perfeita! Eu sou sim! Eu sou como as outras! Eu sou como elas, eu sou como elas sim! (vomita sangue. Antenor sai e a observa, de longe. Diotima caminha até sua casa. Troca de roupa. Retira a maquiagem em frente ao espelho. Sangra. Veste-se de Johansen). DIOTIMA/JOHANSEN - Meu nome não importava. Nem minha origem. Na realidade não tive nome, nem sexo, nem idade, nem terra. Homem ou mulher, criança ou velho, hoje ou amanhã, norte ou sul, os dois gêneros, os três tempos, as quatro idades e os quatro pontos cardeais convergiam em mim e em mim se dissolviam. Minha alma era transparente: quem se somava a ela, fundia-se em uma claridade fria e vertiginosa, e no seu fundo não encontrava nada que fosse meu. Nada, exceto a imagem do seu desejo, até então ignorada por cada um que mergulhava em mim. Agora não tenho mais valor e ninguém pode mais se encontrar em mim. Agora sou o saco de lixo pingando há dias na calçada. Sou o vômito de todos que me comeram, me sonharam, me respiraram e me 
compraram. Sai. ${ }^{252}$

Diotima, a antiga cantora de sucesso da indústria cultural, transforma-se em lixo, traveste-se de lixo. A figura tradicional do travesti é aqui recriada e invertida, porém o que importa não é somente esta inversão sexual, mas a transformação de mercadoria em lixo. Com aquilo que é jogado fora, rejeitado, esquecido, com os traumas que todos querem apagar, com esses rastros/restos de uma civilização do desperdício e, ao mesmo tempo, da miséria, os narradores trapeiros de Miopia compunham a encenação e a narrativa. A exigência de memória, que vários textos de Benjamin ressaltam com força, deve levar em conta as grandes dificuldades que pesam sobre a possibilidade da transmissão e do lembrar, alegorizadas aqui na figura de Diotima que, ao apagar sua memória, torna-se dejeto.

Miopia, ao se configurar como um espetáculo apresentado em uma Usina de Lixo desativada, faz da imagem do lixo recolhido e do acúmulo de ruínas o seu princípio formal para o despertar do choque. Transformar o público em sujeitos do luto, foi fazê-los, através da vivência do choque, aproximar-se de um certo "conhecimento do incognoscível", tornando o espectador um criador que, ao percorrer o trajeto labiríntico do espetáculo foi chamado a completar as lacunas das imagens alegóricas apresentadas, em busca da rememoração do que foi recalcado, no passado e no presente.

Esse espaço da memória deveria ser salvo do naufrágio da história: a experiência do choque seria a plena vertigem do instante, possibilitada graças aos universos recuperados pela rememoração. Os narradores em Miopia seriam os responsáveis por realizar esta rememoração, a partir dos pedaços e das ruínas espalhadas pelo percurso da história fracassada de fundação da cidade utópica. Para Benjamin, em um estudo sobre Proust, a memória seria o espaço em que os acontecimentos se tecem no entrelaçar de sons, cheiros, imagens, traumas e apagamentos. Este tecido da memória, capaz de recolher o que não pode mais ser narrado de forma tradicional, que une música, imagens, luzes, corpos, gestos e palavras, nos propõe uma forma artística muito próxima do que chamamos de feixe ou espessura de dramaturgias. Assim, não seria demais dizer que esta nova forma artística sugerida por Benjamin, capaz de dar conta da

\footnotetext{
${ }^{252}$ ALMEIDA, Ligia Marina; DELMANTO, Ivan; FARIA, Fernanda, et al. Miopia. Inédito, 2006, p. 25 26.
} 
experiência contemporânea, é aquela capaz de tecer múltiplos sentidos e linguagens, dando forma aos traumas e choques da vida danificada de hoje.

Se por um lado o termo dramaturgia remete a uma estética normativa consagrada durante o classicismo francês, à arte de escrever textos dramáticos, que implica por sua vez na existência de princípios e regras que devem ser seguidos a fim de que tais textos sejam produzidos, por outro podemos reconhecer uma expansão significativa no uso desse termo ocorrida ao longo da história do teatro no século XX. Se durante a ascensão do drama burguês o termo dramaturgia esteve relacionado com os modos de confecção de textos dramáticos, a partir da crise do drama a forma dramática é colocada em questão, em um processo de contínua epicização, instaurado pela emergência de uma nova realidade histórica a ser representada:

Aqui a concepção dialética de Hegel da relação forma-conteúdo rendeu frutos, ao se compreender a forma como conteúdo "precipitado". A metáfora expressa ao mesmo tempo o caráter sólido e duradouro da forma e sua origem no conteúdo, ou seja, suas propriedades significativas. (...) Desse modo, no entanto, é colocada já a possibilidade de que o enunciado do conteúdo entre em contradição com o da forma. (...) Surge a contradição quando o enunciado formal, estabelecido e não questionado, é posto em questão pelo conteúdo. Mas essa antinomia interna é a que permite problematizar historicamente uma forma poética, e o que aqui se apresenta é a tentativa de explicar as diversas formas da dramática moderna a partir das resoluções dessas contradições. ${ }^{253}$

A resolução dessas contradições passou pela emergência de formas dramáticas dissolvidas por conteúdo e procedimentos épicos e pelo estabelecimento de uma reflexão e de uma prática acerca da encenação, o que contribuiu para ampliar o conceito de dramaturgia também para as materializações cênicas do texto, consideradas também capazes de construir sentidos. Dentre as referências que contribuíram de maneira significativa para a ampliação da noção de dramaturgia no Ocidente, cabe ressaltar o trabalho desenvolvido por Bertolt Brecht, assim como as elaborações feitas por Antonin Artaud. Através do trabalho do artista alemão, a noção de dramaturgia passa a estar relacionada não somente com a escritura de textos, mas com a articulação dos diversos elementos que compõem a cena. Emerge então, exemplarmente no caso de Brecht, a figura do dramaturg, ou seja, de um profissional que atua como um escritor da cena, que articula o texto escrito com todos os outros elementos cênicos. Também no caso do artista francês o fenômeno teatral é considerado em sua complexidade, a partir de uma

${ }^{253}$ SZONDI, Peter. Teoria do drama moderno. São Paulo: Cosacnaify, 2001, p. 26-27. 
relação não hierárquica estabelecida por ele entre os elementos da cena. Dessa forma, ainda que as estéticas teatrais dos dois artistas sejam extremamente diversas, tanto o trabalho de Brecht como as elaborações de Artaud abriram caminho para o reconhecimento de uma noção de dramaturgia que não está relacionada especificamente com a palavra escrita, mas sim com o funcionamento e a articulação de cada elemento cênico.

Nesse sentido,

Não podemos deixar de mencionar a influência exercida pelos teatros orientais nesse processo. Tanto no caso da Ópera de Pequim como no caso do Teatro de Bali, a partir dos quais Brecht e Artaud puderam desenvolver aspectos cruciais de suas elaborações e práticas teatrais, os elementos da cena são vistos como autônomos, em termos expressivos. Sendo assim, a palavra, por exemplo, deixa de ser nessas formas teatrais a matriz semântica privilegiada do espetáculo, que estabelece uma relação de dependência com os outros elementos, tais como o figurino, a cenografia, e a música. Em muitas formas espetaculares orientais, o que vemos é que cada elemento - em contraste com o conceito wagneriano de obra de arte total (gesamtkunstwerk) que busca modos de expressão homogêneos e harmônicos - contribui para a construção de uma espécie de tecido composto por várias camadas, que se articulam mas não se reforçam ou ilustram, simplesmente. A unidade estética nesses casos é resultante de um profundo jogo de tensões. ${ }^{254}$

Sendo assim, graças também à influência exercida pelos teatros orientais, não somente aquele balinês e chinês, mas também o indiano e o japonês, dentre outros, emerge no Ocidente uma noção de dramaturgia vista enquanto operação através da qual elementos cênicos não convergem para um mesmo ponto, mas são entrelaçados de diversas maneiras, são tecidos. Surge assim, a noção de dramaturgia como textura.

Ao historicizar o conceito de experiência, Walter Benjamin sugere uma forma narrativa que é também histórica. O declínio da experiência, característica da modernidade marcada pela catástrofe das guerras e da produção em massa da destruição, só poderia ser expresso artisticamente por uma forma renovada, capaz de dar conta de uma nova sociedade que nascia.

MÉRCIA - (conduz o público com um livro na mão) "O Narrador", é o que eu estou lendo. "O Narrador" nos coloca diante de um novo desafio para um teatro ligado às questões do nosso tempo: como dar forma sensível aos conflitos dos que estão à margem, destes novos soterrados pela avalanche da história, e que

${ }^{254}$ BONFITTO, Matteo. Tecendo sentidos. Inédito, 2008, p. 3. 
não tem mais nenhum narrador para os nortear. ${ }^{255}$

Se o planetário labiríntico que nos guia, e nos desvia sempre, nesta dissertação não estiver nos conduzindo a rotas equívocas, Miopia procurou responder ao desafio levantado por uma de suas narradoras/personagens por meio de sua polifonia e textura de dramaturgias. Se retomarmos a cena anteriormente citada:

DIOTIMA - Eu sou uma autômata! Uma boneca perfeita! Eu sou sim! Eu sou como as outras! Eu sou como elas, eu sou como elas sim! (vomita sangue. Antenor sai e a observa, de longe. Diotima caminha até sua casa. Troca de roupa. Retira a maquiagem em frente ao espelho. Sangra. Veste-se de Johansen).

A alegoria presente em Miopia, sempre que a forma mercadoria é tematizada, são os autômatos produzidos, primeiro de maneira artesanal e depois de forma fordista, pela empresa do ex-comunista Belmiro. Na cena acima, Diotima, uma estrela decadente da era do rádio, procura ser uma autômata. Enquanto no sentido construído pelo texto, afirma-se esta sua condição de autômata, a encenação apresentava a transformação da personagem em lixo. O tornar-se mercadoria aqui é vestir-se de lixo: seu vestido dourado era substituído primeiro por sua nudez e, aos poucos, por diversos sacos de lixo e por objetos abandonados pelo espaço que eram recolhidos e transformados em adereço, vestimenta, órgãos do seu corpo. A relação entre mercadoria, corpo humano e lixo só pode ser traçada na cena se considerarmos a textura formada por todas as dramaturgias apresentadas.

Reflita um pouco mais e você verá que, quando comprar a crédito e viver em dívida se tornam normas, eles penetram mais fundo na modalidade da vida de consumidor. Podem acelerar o nascimento de novos desejos e abreviar o tempo entre o nascimento de um desejo e sua satisfação - mas também aceleram a fragilização do desejo e sua substituição pelo ressentimento e a rejeição. De modo inevitável, eles abreviam o tempo de vida dos objetos de desejo, ao mesmo tempo que suavizam e aceleram sua viagem em direção à pilha de lixo. ${ }^{256}$

Talvez como tentativa de afirmar esta relação entre crédito e lixo, por podermos considerar, como Bauman, “o crédito e o débito as parteiras do lixo", Diotima, já vestida de lixo e transformada e Johansen, passasse a pedir, em diversas cenas até o

${ }^{255}$ ALMEIDA, Ligia Marina; DELMANTO, Ivan; FARIA, Fernanda, et al. Miopia. Inédito, 2006, p. 7.

${ }^{256}$ BAUMAN, Zygmunt. Vidas desperdiçadas. Rio de Janeiro: Zahar, 2005, p. 138. 
final da peça, dinheiro emprestado ao público. Como diria o Marco Polo de Calvino, é preciso qualquer objeto ou ideia que confunda a reconfortante claridade da "cidade de que falamos", da cidade que "tem a maior parte daquilo que é necessário para existir", e que "tem tudo" daquilo de que seus habitantes necessitam para existir. Johansen e seu corpo de lixo, com seu vagar confuso pelas cenas da peça e pelos bueiros da Usina, é este objeto que, durante toda a peça, assume-se como este incômodo, como o malcheiro, o mal-dito e o mal-visto responsável por causar no público, tratados como cidadãos de Miopia, a sensação, ora suave ora brutal, de que há algo errado e apodrecido no sonho do consumo sem fim.

De certa maneira, todos os narradores-personagens da peça são também transformados, pela encenação, em lixo. A proposta presente no texto, de fazer mover a narrativa por meio da rememoração polifônica dos oito narradores, é destruída pelas outras dramaturgias presentes na encenação. A materialidade das alegorias obscuras propostas pelas ações, muitas vezes incompreensíveis, dos atores, pelos figurinos e pelo espaço monstruoso da Usina, pela iluminação e pelas imagens incoerentes que interrompiam o percurso do público a todo instante, foi capaz de dissolver a presença dos narradores, a ponto de ser quase impossível reconhecer com clareza que determinado personagem estava propondo-se a contar algo.

Na cena citada acima, realizada em um dos vãos livres da Usina, enquanto Diotima/Johansen trocava de roupa e procurava narrar a sua história, havia no plano alto da cena, literalmente por atrás da narrativa do personagem, uma figura fantasmática, iluminada por neon preso ao próprio corpo, que percorria lentamente, de um lado para o outro, o gigantesco tubo de trituração de lixo. Esta figura, que andava ao ar livre por cima do tubo a uma altura de mais de dez metros, deslocava o olhar do espectador para sua ação de sentido impreciso. Ao mesmo tempo em que via o fantasma deslocando-se pelo tubo, o público também contemplava o horizonte iluminado da cidade de São Paulo, exposto como paisagem e moldura ao deslocamento do fantasma, vista propiciada pela altura em que estava localizada a Usina de Compostagem. Inicialmente, segundo a intenção da encenação, este fantasma foi determinado como um dos trabalhadores do cinema. Mas em seu deslocamento no alto do tubo não havia qualquer ação que mimetizasse de maneira transparente o trabalho. Assim, a imagem era exposta à decifração do público, emoldurada pela presença da cidade longínqua, sem pistas definidas para a sua compreensão, obstruindo, ao mesmo tempo, o sentido presente no texto que tinha como foco da ação a narração de Johansen/Diotima. 


\section{Saída interrompida 6: A Dialética no Teatro: na sala de espera do labirinto / A casa e a usina: a cena contra o texto/ o labirinto contra o drama / Sexta crise}

A morte é um diálogo Entre o Pó e o Espírito. "Dissolve-te" - ela diz - mas este"Outra crença me inspira".

Opõe-se a Morte em dúvidaVai-se embora o Espírito Deixando só - como argumento Uma capa de argila. ${ }^{257}$

\section{VI.1. Narrativa do processo de ensaio: a casa e a usina}

A pesquisa para o desenvolvimento do espetáculo começou em uma casa vazia, no bairro da Saúde, em São Paulo. Naquele momento, o grupo sequer conhecia o espaço da Usina de Lixo e o objetivo inicial era apresentar a peça em uma casa, buscando compreender as relações entre indivíduo e sociedade sob o capitalismo. Durante o ano inicial de pesquisa e criação, o grupo permaneceu na casa e construiu a versão base do texto teatral, sempre a partir desta investigação entre indivíduo e coletivo. O processo de improvisações começou sobre o estudo de conceitos da filosofia dialética. A cada semana, eram realizadas discussões e leituras norteadas pelos conceitos selecionados. Após os encontros teóricos, a semana era estruturada a partir da experimentação física dos conceitos: os aquecimentos e exercícios corporais eram transformados em partituras de ações, depois recriadas em improvisações temáticas. Um dos exercícios praticados naquele período:

\footnotetext{
Experimentação física do conceito de contradição. Atores movimentam-se pela sala. Buscam movimentos circulares. Sob nova diretriz, movimentos retilíneos. Agora o movimento circular se transforma em movimento retilíneo. O movimento retilíneo se transforma em movimento circular. ${ }^{258}$
}

\footnotetext{
${ }^{257}$ DICKINSON, Emily. Alguns poemas. São Paulo: Iluminuras, 2006, p.101.

${ }^{258}$ DELMANTO, Ivan. Caderno de direção - 2004. Inédito, 2004, p. 56.
} 
Já ao estudar o fetiche da mercadoria, os atores exploraram movimentos automatizados e hipnóticos, para tentar dar conta de uma realidade em que as coisas ganham aparência de vida, assumindo o lugar das relações humanas. Deste universo de pesadelo, aparentemente sem saída, as improvisações passaram a questionar as possibilidades de utopia, a tatear em busca de saídas de emergência. Surgiu então o primeiro eixo da dramaturgia, que o grupo chamou de cidade dos sonhos/cidade pesadelo. No espaço da casa, os atores eram convocados a elaborar improvisações a partir deste tema central, recebendo como estímulos textos, sons e imagens, muitas vezes participando de instalações plásticas e de vídeo que eram montadas pelo músico, pelo iluminador e pelo cenógrafo, gerando novas paisagens, novos ambientes de sonho e pesadelo que eram então vivenciados e transformados em cena.

A criação percorria o caminho do tema urbano. Quando resgatou-se o parágrafo do historiador Leôncio Basbaum, que narrava a expulsão de desempregados de São Paulo pelo governo Vargas, o grupo passou a experimentar o eixo da fundação de uma cidade por estes desempregados. As cenas criadas trouxeram a sugestão de oito personagens, todos tendo como cenário de suas histórias esta cidade fundada em meio ao nada. Todos os atores experimentaram, durante mais de dois meses, cada personagem, trazendo cenas e realizando improvisações e exercícios corporais. Ao final deste período, cada ator fez uma seleção das cenas preferidas realizadas pelo grupo e montou um painel buscando uma sugestão de fábula. Decidimos quem faria cada personagem e eu trouxe uma primeira versão de roteiro, baseada nas sugestões individuais para a fábula.

Apenas neste momento do processo de criação surgiu a Usina. Quase que por acaso, em busca de um local para apresentar a peça, já que a casa que até ali servira de sala de ensaio não poderia mais ser utilizada, o grupo conheceu a imensa Usina de Compostagem, espécie de fábrica de lixo abandonada na periferia leste da cidade, cercada pela vegetação incrivelmente verde do parque do Carmo, em um contraste aberrante entre degradação e natureza, mercadorias e cidadãos descartados. $\mathrm{O}$ roteiro que havia sido criado em uma casa, espaço privado por excelência, teria então que ser apresentado em uma usina de lixo. A contradição entre texto e cena, que caracterizaria o espetáculo a partir daqui, surgia sob os escombros e espaços abandonados do castelo assombrado por lixo. De "improvisações críticas" realizadas pelos atores sobre o roteiro, surgiram uma primeira e uma segunda versão de dramaturgia, que foi colocada 
de pé no dia 12 de novembro de 2005. As outras inúmeras versões para o texto do espetáculo foram então construídas sobre este material.

No entanto, como já mencionamos no primeiro capítulo, desta primeira versão de roteiro, transformada em uma grande improvisação que durou seis horas, até a versão definitiva do texto, utilizada durante a temporada do espetáculo, não ocorreram modificações essenciais. Ordens de cenas foram modificadas, falas e monólogos suprimidos, mas a narrativa permaneceu, bem como a trajetória básica dos personagens. Entretanto, o espetáculo criado pouco assemelhou-se com esta primeira versão de roteiro apresentada; na verdade, o espetáculo pouco assemelhou-se com o texto escrito e talvez esta contradição possa nos fazer entender um pouco mais sobre Miopia e sobre o sua relação com a formação histórica brasileira.

Ao se iniciarem as primeiras improvisações na usina, o grupo logo percebeu, não sem perplexidade, que o universo do texto não se adaptava àquele novo espaço cênico. Mais do que isto:

\begin{abstract}
Estávamos sendo engolidos pela usina. O nosso tema, a fábula dos desempregados de 1935, as histórias de cada personagem, tudo parecia inútil naquele lugar, o espaço era maior e tinha mais significado. Foi quando tentamos recorrer aos estudos da dialética, e acho que fizemos um resgate dos estudos de contradição, de movimento, de totalidade, na verdade para destruir e negar tudo ${ }^{259}$.
\end{abstract}

A verdade é que, antes da chegada à usina, os estudos sobre dialética e teatro haviam conduzido o grupo a uma forma teatral, representada pela construção do texto, ligada aos padrões do teatro épico. Cabe lembrar: em busca deste "salto de tigre' que percebe no passado os traços do presente, a fábula de Miopia unia aos desempregados expulsos por Vargas a fundação de uma cidade utópica, que via seus ideais de uma nova sociabilidade diluídos por uma estrutura social que não conseguia escapar dos ditames da forma mercadoria, representada pela inauguração de um cinema que só exibia comerciais e que, aos poucos, contaminava a cidade com uma imaginária "peste das imagens". Para abordar este conteúdo contemporâneo, a imbricação entre mercado e cultura, a colonização dos mais recônditos ideais utópicos pelas relações de troca, o grupo escrevera, durante o estudo dos procedimentos de Stanislavski, Meyerhold e Brecht, um texto teatral com traços marcadamente épicos: o confronto entre diversos personagens narradores, que davam versões contraditórias à história, a fragmentação da

\footnotetext{
${ }^{259}$ FARIA, Fernanda. Atriz da II Trupe de Choque, em depoimento gravado para o documentário Miopia,
} 2006, direção de André Moncaio. 
fábula, rompendo com as unidades de ação, de tempo e de espaço, a inserção de canções e fragmentos líricos que interrompiam a todo instante o transcorrer da fábula. Veremos a seguir que a discussão sobre a persistência ou não dos gêneros épico e dramático em Miopia e nas manifestações teatrais inspiradas pela tradição do teatro épico não é apenas uma questão de nomenclatura, ligada a tentativas de ressurgimento de uma estética normativa.

\section{VI.2. Nova Digressão: historicizando o pós-dramático}

Em seu Teatro Pós-dramático, Hans Thies Lehmann identifica, ao longo de séculos, a predominância no teatro europeu da "presentificação de discursos e atos sobre o palco por meio da representação dramática imitativa". Isto significa que o teatro teria sido pensado tacitamente como teatro do drama, mesmo nas suas manifestações épicas surgidas a partir das vanguardas históricas. Incluir-se-iam entre seus fatores teóricos conscientes as categorias "imitação" e "ação", assim como a concomitância quase automática das duas categorias. Pode-se destacar como tema inconsciente, associado à compreensão teatral clássica, a tentativa de formar ou fortalecer por meio do teatro um contexto social, uma comunidade que unisse emocional e mentalmente o público e o palco. "Catarse" seria então a denominação teórica para esta função do teatro que não é de modo algum essencial e atemporal: instauração de reconhecimento afetivo e de comunhão mediante os afetos apresentados pelo drama em seus limites e transmitidos aos espectadores. Esses traços não podem, segundo Lehmann, ser dissociados do paradigma teatro dramático, cujo significado vai muito além da validade de um simples ordenamento poético. O teórico alemão não explicita o que estaria para "além do gênero poético" - uma das lacunas do livro, que não consegue estabelecer esta conexão entre dissolução do drama, emergência de uma nova forma teatral, e momento histórico, neste caso, a emergência do momento tardio do capitalismo.

O conceito de pós-dramático, forjado por Lehmann, é problemático inicialmente por sua amplitude: ao agrupar formas muito distintas sob o paradigma "ampliado de drama", reunindo manifestações tão distintas quanto os dramas de Lillo, Hauptmann e Ibsen e o teatro épico de Maiakovski ou Brecht sob o critério de apresentarem todas a estrutura da narrativa, da imitação e do diálogo, por exemplo, Lehmann dissolve as especificidades, diferenças, contradições e o movimento dos fenômenos teatrais sob a generalidade abstrata do conceito. No entanto, tal conceito tem o mérito de ressaltar a 
relação dialética que o teatro épico, principalmente o de Brecht, que chegou a teorizar sobre tal aspecto, estabelece com o drama: tal teatro não pretende abandonar a forma dramática mas sim suspendê-la, negando alguns de seus procedimentos, como a "catarse" e a unidade de ação e conservando outros, como o diálogo, a narrativa (estruturada de maneira fragmentada e não linear, mas conservada), os personagens e a intenção mimética (também estruturada por outros parâmetros, voltada para uma historicização das ações apresentadas). Veremos adiante que esta relação dialética e necessária entre o teatro épico e o drama será questionada e deslocada em Miopia, a partir da feição labiríntica da peça.

Se é possível, como menciona de passagem Lehmann, perceber no paradigma dramático muito mais do que características estéticas, é necessário percorrer algumas pistas, que seriam capazes de nos revelar a formação social que se esconde sob a estrutura formal dramática. Durante muito tempo, o discurso estético tradicional identificou como essência do drama o conflito. Desta identificação, as contradições sociais apareceriam, sob a forma do diálogo, como as irreconciliáveis exigências e posições de classes antagônicas. Talvez possamos ir além desta concepção, que une correta mas insuficientemente a luta de classes ao conflito de personagens sob a forma dramática, se buscarmos primeiro um novo olhar sobre o conceito de classe social:

\begin{abstract}
Definir classe desta forma significa diferenciar radicalmente o modelo marxista de classes da análise sociológica convencional da sociedade em estratos, subgrupos, elites profissionais, e assim por diante, cada um dos quais podendo presumivelmente ser estudado isolado dos outros(...) Para o marxismo, o próprio conteúdo de uma ideologia de classe é relacional, no sentido de que seus valores sempre se posicionam em relação à classe oponente, e se definem em oposição a ela: normalmente, a ideologia de uma classe dominante explorará várias estratégias da legitimação de seu próprio poder, enquanto uma cultura ou ideologia oposta buscará, amiúde de maneira velada e empregando estratégias dissimuladas, contestar e minar o sistema de valores dominante ${ }^{260}$.
\end{abstract}

É neste sentido que partiremos do pressuposto de que, fazendo eco a Mikhail Bakhtin, o discurso das classes - categoria em termo da qual o drama pode ser revisto é essencialmente dialógico em sua estrutura. Se a forma normal do diálogo é essencialmente antagônica e se, no diálogo da luta de classes, dois discursos lutam dentro da unidade geral de um código compartilhado, entender o drama é revelar este embate discursivo sob o seu tecido formal, constituindo-o de forma contraditória,

\footnotetext{
${ }^{260}$ JAMESON, Fredric. O inconsciente político. São Paulo: Ática, 1996, p. 77.
} 
gerando lacunas e fraturas em espaços de aparente harmonia. Mais do que ligar a estrutura de uma sociedade fracionada em classes à oposição entre antagonista e protagonista, podemos perceber em todos os traços da forma do drama, que nunca é pura mas é sempre marcada por cesuras e contradições (como a presença do passado nos dramas de Ibsen ou dos monólogos nas peças de Tchecov), a presença constante da dualidade: os pares binários tempo e espaço, causa e efeito, ação e palavra, indivíduo e coletivo, corpo e mente, natureza e humanidade, marcam todas as criações dramáticas. Esse embate, representado pela voz de uma classe hegemônica e pela voz abafada dos marginalizados, podre ser organizado em torno de uma unidade mínima, a que chamaremos, seguindo Jameson, de ideologema. Tal procedimento é justificado por sua capacidade de mediar entre concepções de ideologia como opinião abstrata, valor de classe e outros, e o material estético. O ideologema pode ser entendido como uma "formação anfíbia", cuja característica estrutural essencial pode ser descrita como sua possibilidade de se manifestar como pseudo-ideia - um sistema conceitual ou de crença, um valor abstrato, uma opinião ou um preconceito - ou como uma protonarrativa, uma fantasia de classe essencial com relação aos personagens coletivos que são as classes em oposição, fantasia que permite que uma aparente coerência interna e formal reprima o impensável, o que se coloca além dos limites de representação experimentados por determinada sociedade.

Salvo engano, a análise de Miopia pode então revelar, sob suas diversas dramaturgias, o trabalho complexo de transformação daquela matéria-prima inicial que é o ideologema que por nós será investigado: o drama.

O romance é um ideologema narrativo cuja forma externa, secretada como uma concha ou um exoesqueleto, continua a emitir sua mensagem muito depois da extinção do hospedeiro ${ }^{261}$.

Já mencionamos como torna-se problemático o conceito de "drama ampliado" criado por Lehmann para caracterizar experiências artísticas e momentos históricos tão díspares quanto o drama burguês e o teatro de Meyerhold ou de Brecht. No entanto, pode-se admitir que qualquer reflexão que envolva procedimentos do teatro épico, como a que foi conduzida pela II Trupe de Choque durante todo o processo de criação de Miopia, tem como horizonte de embate e de suspensão, que envolve negação mas também conservação, a forma dramática.

Se, como o romance, o drama é um ideologema que persiste, para além do

${ }^{261}$ JAMESON, Fredric. Op. cit., p. 154. 
momento histórico em que surgiu e foi teorizado (permanecendo, inclusive nas formulações do teatro épico), é possível perceber em Miopia, em resultado contrário às intenções e mesmo à pesquisa artística empreendida por seus criadores, em uma obra que desconfessa a si mesma, a destruição dessa forma hegemônica dramática. Tal processo de destruição, se não estivermos enganados, seria capaz de revelar não só novos processos de reapropriação, de neutralização e de cooptação de conflitos de classe, mas, principalmente, de desvelar a emergência de uma formação social caracterizada por uma nova configuração entre o capital e o trabalho no mundo contemporâneo. Por outro lado, é possível perceber neste processo também a conservação da forma dramática, ligada a uma manifestação do teatro épico que dialoga com a tradição épica brasileira ao justapor drama e antidrama na mesma forma dilacerada. Se esta hipótese puder ser confirmada, Miopia seguiria a tradição do teatro épico brasileiro, conforme pudemos constatar em Vianinha, em capítulo anterior, de produzir uma forma em que a dialética encontra-se estagnada, paralisada, fazendo com os procedimentos dramáticos convivam com os de procedência épica sem que sejam uns transformados pelos outros, em uma coexistência de gradientes acirrados, tal a distância entre os extremos. Espaço público e espaço privado encontram-se radicalmente separados, impedindo que o indivíduo típico represente plenamente sua totalidade social, impedindo o objetivo quase científico de historicizar a realidade em sua complexidade e dinamismo. É possível encontrar este isolamento do espaço privado familiar na terceira cena de Miopia:

\section{IMAGEM DO ABANDONO}

MÉRCIA - Está muito frio lá fora. Não inventa de sair não. Hoje ele já saiu o que tinha que sair.

MARIBEL - Ele quer ir lá fora.

MÉRCIA - Está muito frio. Melhor ele ficar em casa. Antenor, pare com isso já.

MARIBEL - Hoje é aniversário dele.

Eu não vou deixar que ele passe o aniversário isolado do mundo.

MÉRCIA - Só faz aniversário quem tem o que comemorar. Antenor! Se você não se comportar você vai para a cozinha. O seu pai me dizia sempre que eu ia piorar de tanto me preocupar com ele. É o meu castigo. Eu acho às vezes.

MARIBEL - O meu castigo é ficar aqui, presa neste buraco.

Eu vou embora, já falei. É o meu último comunicado.

MÉRCIA - Ele vai acabar nos matando. Desde que ele nasceu o sol sumiu. O carrasco.

MARIBEL - Ele não quer mais ser carrasco. Nós vamos no cinema, para nos divertir, não é Antê?

MÉRCIA - Até quando você vai insistir nisso? Eu já não te proibi 
de levar o menino no cinema?!! Você eu já perdi, mas ele não vai, ouviu?!. Prefiro que ele fique preso com os brinquedos de tortura!! (derruba as garrafas que estavam no armário e chora) (...)

MÉRCIA - Vocês todos nesta cidade estão conspirando para me assassinar! Este cinema, estas lojas, estes bonecos vivos, todo este excremento podre que vocês compram e vendem para viver, comprar e vender para viver, comprar e vender! (Maribel e Antenor a trancam no quarto) Fique com ele lá fora uma meia hora, menina. Não saiam do quintal. ${ }^{262}$

Os personagens encontram-se tão abandonados, que a cena perde sua capacidade de referência a qualquer realidade externa: espacial, narrativa ou histórica. A cena foi apresentada em uma garagem abandonada na Usina, em um desvio de percurso, em que uma ladeira tortuosa afastava a peça do seu edifício principal. Quanto à narrativa, a cena era apresentada como um estilhaço, sem conexão alguma com as situações anteriores ou seguintes, em uma espécie de apresentação dos personagens. Esta apresentação, no entanto, era incapaz de revelar as ligações desta família com o mundo. Representada de maneira dramática, quase tradicional, o conflito familiar dos personagens vetorizava todas as demais dramaturgias da cena que, ao invés de criar outros sentidos, como a maior parte da encenação, aqui apenas "ambientava" as tensões subjetivas, criando um pequeno quarto em meio às ruínas e à sujeira da garagem. A fala final de Mércia, que menciona o cinema e a "compra e venda" constante executada por todos na cidade é incapaz de transcender este universo de isolamento, em tentativa semelhante aos autores da crise do drama, Hauptmann, por exemplo, que buscaram em vão expressar, apenas através do diálogo intersubjetivo, conteúdos épicos, advindos do universo público do tecido histórico ${ }^{263}$.

Parece-nos que a estrutura contraditória do drama revelaria um espaço transparente em que os antagonismos de classe, a posição do indivíduo no mundo e a relação com sua própria subjetividade, podiam ser claramente percebidas e problematizadas. O mundo seria capaz de ser imitado e representado como fruto da ação contínua de sujeitos movida pela superação da contradição, identificada em todos os setores da vida social. Este teatro dramático estaria sempre subordinado ao primado do texto. Mesmo quando a música, a dança ou ações físicas não realistas eram inseridas ou predominavam (como no caso do teatro de Meyerhold), o texto continuaria a ser determinante no sentido de uma totalidade cognitiva e narrativa tão apreensível quanto a

${ }^{262}$ ALMEIDA, Ligia Marina; DELMANTO, Ivan;FARIA, Fernanda, et al. Miopia. Inédito, 2006, p. 3.

${ }^{263}$ Ver, a este respeito, SZONDI, Peter. Teoria do drama moderno. São Paulo:Cosacnaify, 2004. 
realidade. O texto surgiria centrado em sua função como texto para interpretação de papéis. Se analisarmos o processo de criação da cena citada acima, veremos que este textocentrismo dramático esteve presente: a cena era a única de toda a peça que não fora criada através de improvisações. Escrevi o texto isoladamente, a partir de uma leitura do romance Som e Fúria, de William Faulkner, e o objetivo da cena era retratar a família de Mércia após a construção do cinema. Durante o processo de encenação, percebemos que a forma dramática do texto não dava conta deste objetivo inicial, já que as relações intersubjetivas não davam espaço ao tema do cinema. O texto e a cena foram mantidos, mas mudando de intenção dentro do contexto geral da peça: passaram a ser encarados pelo grupo como uma introdução aos personagens. A convivência desta cena dramática com o restante da peça parece-nos testemunhar esta espécie de convívio aberrante de contrários, abordado sob diversos prismas ao longo desta dissertação.

Lehmann não identifica este convívio entre drama e épico. Pelo contrário, afirma que procedimentos como o coro, narrador, intermédio, prólogo e epílogo, apartes e milhares de fendas sutis no cosmos dramático, incluindo todo o repertório brechtiano da representação épica, poderiam ser incorporados ao drama sem dissolver totalmente a vivência específica do teatro dramático.

Segundo o teatrólogo alemão, esta contradição congelada entre forma épica e dramática, que identificamos em Miopia, não é significativa. Na verdade, tal oposição não existiria: para Lehmann, não é decisivo saber se e em que medida as formas de discurso poéticas tinham efeito na textura dramática do teatro das vanguardas ou do teatro épico, ou em que medida estas dramaturgias épicas eram utilizadas: o drama seria capaz de incorporar tudo isso sem perder o seu caráter dramático. Para o teórico alemão, o teatro dramático sempre foi construção de ilusão. Este teatro pretenderia erguer um cosmos fictício e fazer com que o "palco que significa o mundo" aparecesse como um palco que representasse o mundo - abstraindo, mas pressupondo, que a fantasia e a sensação dos espectadores participam da ilusão. Para uma tal ilusão não seria necessária a integridade e nem mesmo a continuidade da representação, mas o princípio segundo o qual o que é percebido no teatro pode ser referido a um mundo, isto é, a um conjunto. Totalidade, ilusão e representação do mundo estariam na base do modelo drama, ao passo que o teatro dramático, neste sentido semelhante ao teatro épico, por meio de sua forma, afirmaria a totalidade como modelo do real. Para Lehmann, o teatro dramático só termina quando esses elementos não mais constituem o princípio regulador, mas apenas uma variante possível da arte teatral: 
O presente estudo tem como ponto de partida a convicção de que a ruptura das vanguardas históricas em torno de 1900, sem dúvida profunda, conservou o essencial do "teatro dramático" apesar de todas as inovações revolucionárias. As novas formas teatrais surgidas serviam à representação, agora modernizada, de universos textuais, procurando justamente salvar o texto e sua verdade da desfiguração gerada por práticas teatrais que haviam se tornado convencionais, de modo que puseram em questão o modelo tradicional da representação e da comunicação teatrais de maneira limitada. É certo que os recursos de encenação de Meyerhold conferiam extrema estranheza às peças, mas elas eram representadas como um todo coeso. É certo que os revolucionários do teatro romperam com quase tudo o que viera antes, mas insistiram na mimese de uma ação no teatro, mesmo ao empregarem recursos de encenação abstratos e causadores de estranheza. ${ }^{264}$

Por outro lado, no curso da ampliação e em seguida da onipresença das mídias na vida cotidiana desde os anos 1970, teria entrado em cena, ainda seguindo Lehmann, um modo de discurso teatral novo e multiforme, designado pelo autor alemão de teatro pósdramático. No teatro pós-dramático, as linguagens formais desenvolvidas desde as vanguardas históricas se tornariam um arsenal de gestos expressivos que lhe serviriam para dar uma resposta à comunicação social modificada sob as condições de ampla difusão da tecnologia da informação. O problema deste "conceito ampliado de drama" estabelecido pelo autor alemão é que, sob o quase infinito guarda-chuva do gênero dramático, dissolve-se o processo histórico real e a dialética das formas teatrais que expressa tal processo.

Já mencionamos que Lehmann tem dificuldades em considerar o pensamento dialético de Brecht, que afirma que o seu teatro épico suspende o drama e não o destrói, mas ainda não compreendemos o contexto filosófico a que a teorização do pósdramático está ligada. A suspensão, que em sentido dialético representa negação determinada e não absoluta - o que envolve portanto também a conservação de aspectos significativos da tradição dramática como a narrativa e o diálogo - , não é considerada por Lehmann, já que o seu horizonte filosófico é aquele emoldurado por Heidegger e seu conceito não dialético de destruição ou de des-construção, para usar termo caro a Derrida, outro dos seus interlocutores.

Nomear como igualmente dramáticas todas as formas teatrais que se utilizam do diálogo e da narrativa, como faz Lehmann, além de ignorar o processo histórico exposto

${ }^{264}$ LEHMANN, Hans-Thies. O teatro pós-dramático. São Paulo: Cosacnaify, 2007, p. 26-27. 
acima, com suas importantes distinções formais, é criar um conceito impreciso que denomina como "pós-dramáticas" todas as manifestações teatrais, da dramaturgia lírica e fragmentada de Heiner Müller, da dramaturgia dos objetos de Tadeusz Kantor à performance de Marina Abramovic, que prescindem da narrativa. Lehmann divide a história teatral em um antes e um após a "morte da narrativa" e tal procedimento crítico converte-se em ideologema do capitalismo em seu estado tardio, como o drama já fora no estágio imperialista do capital. Segundo o autor alemão:

Pode causar estranheza o fato de que nesse ponto está em jogo aquele truque teatral que talvez seja o mais antigo, ao qual se dá o nome de destino. Mas de fato parece propícia ao teatro a fórmula segundo a qual destino é uma outra palavra para representabilidade. A representabilidade, como experiência ao mesmo tempo estética e ética, é a manifestação do destino, tema principal do teatro trágico. Mas se o teatro dramático seguiu o padrão do destino antigo nos moldes de uma narração, do desenrolar de uma fábula, no teatro pós-dramático chega-se a uma articulação que não se baseia na trama, mas na manifestação do corpo: o destino fala aqui a partir dos gestos, não a partir do mythos. ${ }^{265}$

Assim, o que uniria a representação dramática e a representação pós-dramática seria a "apresentação de um destino". Mais adiante Lehmann caracteriza o destino como "transcendência no mesmo sentido que a vida humana transcende a vida biológica por meio da plenitude, do aprofundamento e da diversificação das imagens dessa vida”. Assim, a representação (ou destino, tratados por Lehmann como sinônimos) seria esta espécie de "vida concentrada, intensificada", exibida no teatro. Chama atenção a escolha da ideia de destino para definir as duas formas teatrais mencionadas. Talvez seja possível onde o autor alemão escreve destino, ler ideologia. Neste sentido, já em 1950, em Mitologias, Roland Barthes propôs a noção de ideologia como a naturalização da ordem simbólica - isto é, como a percepção que reifica os resultados dos processos discursivos em propriedades da "coisa em si”. Parece-me que assim como a ideia de destino apresenta uma realidade fechada e não mais transformável, as formas do drama e do pós-drama são ideologemas porque capazes de nos apresentar a realidade social a partir de um "recalcamento primário" de um antagonismo, ligado a determinada constelação histórica.

Se o drama burguês esteve ligado aos recalcamentos inerentes ao espírito do capitalismo, as formulações acerca do teatro pós-dramático em Lehmann talvez

${ }^{265}$ LEHMANN, Hans-Thies. O teatro pós-dramático. São Paulo: Cosacnaify, 2004.p. 401-402. 
expressem o que Luc Boltanski e Ève Chiapello chamaram de "novo espírito do capitalismo",266.

\begin{abstract}
A aura da presença corporal continua a ser o ponto do teatro no qual se dá o desvanecimento de todo o significado em favor de uma fascinação distante do sentido, de uma presença espetacular, do carisma ou da irradiação (...). O signo central do teatro, o corpo do ator, recusa o papel do significante. (...) O sujeito da percepção não pode mais se apoiar num ordenamento representativo (...) Em sentido estrito, aqui nada se transmite ou reproduz, pois não há nada que possa ser transmitido ou reproduzido. A visão vidente acompanha o surgimento do visto e do vidente que está em jogo no acontecimento da visão, do tornar-se visível, e do fazer-se visível. ${ }^{267}$
\end{abstract}

O corpo do ator no teatro pós-dramático não é um corpo que nada transmite ou representa. Pelo contrário, assim como o drama foi capaz de "mimetizar ações" de determinado momento histórico, "esta fascinação distante de sentido" que para Lehmann caracteriza a presença do ator pós-dramático é capaz de revelar, através de um processo mimético de outra ordem, o sentido de ações humanas coletivas e contemporâneas.

A disseminação dos novos mecanismos de sedução da estética da mercadoria criou uma moralidade da diversão, impondo e determinando como apresentar-se, divertir-se, ostentar e obter prazer. A procura interminável de novas relações, de novos produtos, relaciona-se com a busca de emoções inéditas. Para o sociólogo André Gorz, não se trata apenas da satisfação de um desejo, de um gosto ou de uma inclinação, mas de uma curiosidade generalizada movida por uma obsessão difusa - esta é a "funmorality em que reina o imperativo de se divertir e de explorar a fundo todas as possibilidades de se fazer vibrar, gozar ou gratificar". O imperativo do gozo, e o consequente soterramento da experiência reflexiva, pode ser associado, nas formas artísticas descritas por Lehmann, ao que ele identifica como uma crescente ritualização do teatro, em que as peças procurariam transmitir ao público, por meio de uma overdose de sensações prazerosas, acolhedoras e uniformizadoras, uma realização comunitária perdida:

O teatro pós-dramático é a substituição da ação dramática pela cerimônia, com a qual a ação dramático-cultual estava intrinsecamente ligada em seus primórdios. ${ }^{268}$

\footnotetext{
${ }^{266}$ BOLTANSKI, Luc e CHIAPELLO, Ève. O novo espírito do capitalismo. Martins Fontes: São Paulo, 2009.

${ }^{267}$ LEHMANN, Hans-Thies. op.cit.,p.157-162.

${ }^{268}$ Idem, op. cit., p. 115.
} 
A sociedade de consumo estava associada, até meados da década de 1970, a um modelo de organização dominante: a estrutura verticalizada e sistêmica da fábrica fordista e da burocracia pública e privada. Caracterizada por uma rígida separação entre o planejamento da produção e a execução das tarefas, entre trabalho intelectual e trabalho físico, a fábrica fordista possuía uma pesada estrutura constituída como pirâmide com múltiplos níveis hierárquicos, como estrutura disciplinar. Tal sociedade foi representada pelos procedimentos do teatro épico.

O modelo fordista e burocrático, no entanto, começou a entrar em crise e a ceder espaço para novas formas de organização quando na década de 1970 os Estados nacionais perderam sua capacidade de promover o crescimento indefinido da demanda. Como resposta à intensificação da competição, as corporações adotaram como estratégia a busca da flexibilidade caracterizada por permanentes inovações tecnológicas, organizacionais, comerciais e administrativas. O objetivo principal dessas transformações em suas variadas formas era lidar com a incerteza causada pelo ritmo veloz das mudanças no ambiente econômico, institucional e tecnológico das empresas, aumentando a flexibilidade da produção, gerenciamento e marketing e reduzindo custos de mão-de-obra mediante a automação de trabalhos, eliminação de tarefas e supressão de camadas administrativas. Externamente, a flexibilidade organizacional foi alcançada por meio da terceirização e da formação de redes entre empresas, cuja conexão pode se dar entre várias empresas de pequeno e médio porte, pela subcontratação de pequenas empresas ou por alianças estratégicas entre grandes corporações.

\begin{abstract}
Vivenciamos um monótono fluxo de signos que se esvaziaram de seu caráter comunicativo, e já não podem ser apreendidos como totalidade poética, cênica e musical: versão pós-dramática e negativa do sublime. (...) Nesses momentos da não-compreensão, do choque, da percepção do indizível, experimenta-se a exposição a um outro tempo. ${ }^{269}$
\end{abstract}

Talvez seja possível perceber que este monótono fluxo de signos está diretamente ligado às mudanças na relação entre capital e trabalho. Tais transformações na esfera produtiva do valor geraram transformações profundas nas formas de se experienciar o tempo e o espaço. A aparente ausência de tempo e de espaço teorizada pelo pósdramático de Lehmann revela um espaço e um tempo precisos, em que a quebra da temporalidade e da espacialidade narrativas têm ainda um potencial mimético, de

${ }^{269}$ Idem, op. cit., p. $310-319$. 
representação desta realidade do estágio tardio de produção capitalista.

Do ponto de vista comercial, a nova situação de concorrência acirrada fez com que as empresas passassem a explorar nichos de mercado altamente especializados e de pequena escala, investindo cada vez mais na inovação e customização dos produtos. $\mathrm{O}$ produto deixou de ser o único ponto de contato com os consumidores, em uma relação muda, e a empresa passou a investir em formas mais intensas de relacionamento com o cliente.

O caráter fragmentário da percepção (...) se tornará expressamente consciente no teatro pós-dramático. Aqui se nega ao espectador o desejo de orientação. $O$ espectador escolhe o que vai ver. [grifo $\mathrm{meu}]^{270}$

O espectador de que nos fala Lehmann, que de resto tem sua escolha limitada pela própria forma teatral do que lhe é apresentado e vendido, pode ser visto, se não estivermos equivocados, como o consumidor contemporâneo, assolado pelo discurso de que pode escolher o produto e o serviço que quiser. Este teatro de prestação de serviços, relaciona-se com o fato social de que, nesse momento, mesmo as indústrias produtoras de bens adotam a lógica da prestação de serviços, na medida em que não apenas oferecem atendimento personalizado e soluções customizadas permanentemente, requerendo a participação ativa e contínua do cliente na produção, mas também porque os próprios bens convertem-se em plataformas por meio das quais se dá a prestação de um serviço. Com isto, a lógica dos serviços ultrapassa os limites do setor terciário, estendendo-se para todos os setores econômicos, inclusive o industrial, convertendo-se na lógica dominante da nova economia.

Por fim, as formas de gestão também foram largamente modificadas para corresponder a este novo cenário. O modelo da administração científica, baseado no planejamento centralizado da divisão técnica e social do trabalho e nas técnicas disciplinares, é cada vez mais deslocado pela gestão de pessoas, relacionamentos, redes e processos. Este novo paradigma é descrito pelo conceito de trabalho imaterial. O trabalho imaterial é aquele "que produz o conteúdo informacional, cultural e emocional da mercadoria".

O conteúdo informacional da mercadoria diz respeito às tarefas de trabalho que são cada vez mais subordinadas à capacidade de tratamento da informação e de comunicação horizontal e vertical, enquanto o conteúdo cultural faz alusão a atividades de definição

${ }^{270}$ Idem, op.cit., p. 173. 
de normas culturais e artísticas, de modas, gostos, padrões de consumo e da opinião pública. O trabalho imaterial produz também o conteúdo emocional da mercadoria, constituído sobretudo na relação com o consumidor, gerando cuidado, conforto, tranquilidade, segurança, sentimento de bem-estar, excitação, diversão, prazer, mas também nas interações entre os parceiros corporativos, provendo cooperação, confiança, motivação etc. ${ }^{271}$

O trabalho imaterial, nesse sentido, torna-se produtivo porque transforma os consumidores e os parceiros corporativos naquilo que diz respeito aos seus modos de pensar, agir e sentir, aos seus estilos de vida. Se agora as empresas geram valor e conquistam seu lucro cada vez menos por meio de bens materiais, mas por meio de bens intangíveis e de consumo imediato, como é o caso dos serviços, do entretenimento, das experiências, do conhecimento, das informações e da comunicação, então o trabalho imaterial se torna a forma de trabalho central (ainda que de modo algum a única) dessa nova economia.

A radicalização desse processo e a busca por novas formas de diferenciação e superação dos concorrentes levaram as empresas a criarem uma nova modalidade de consumo, indo além dos bens e serviços: o consumo de experiências. Experiências estão para além dos serviços. Não são os serviços ou bens que de fato são vendidos, mas a experiência resultante, repleta de sensações e emoções, e sobretudo a memória afetiva que resulta do evento consumido. É importante identificar a semelhança deste processo com a experiência do espectador do teatro pós-dramático:

[O teatro-pós dramático] é prática artística de desconstrução multimedial ou intermedial do acontecimento instantâneo. (...) O espectador do novo teatro procura (...) as correspondências baudelairianas no templo do teatro (...) [O teatro pós-dramático] é mais presença que representação, mais experiência partilhada que comunicada, mais processo que resultado, mais manifestação que significação, mais energia do que informação. ${ }^{272}$

A citação acima relaciona aspectos importantes desta nova forma de produção de valor: a experiência, a comunicação, a energia. O papel estratégico fundamental desempenhado pelo dispositivo de controle emocional na nova economia e sua ampla difusão tanto no trabalho quanto no consumo passa a estruturar largamente as relações entre as pessoas, moldando, com isto, uma parte ampla do habitus emocional contemporâneo. No caso do consumo, a partir das novas técnicas de gestão de

\footnotetext{
${ }^{271}$ ANDRADE, Daniel Pereira. Op.cit., p. 43.

${ }^{272}$ LEHMANN, op.cit., p.139-143.
} 
relacionamento e da experiência do cliente, este passa a ser vigiado e controlado incessantemente, constituindo-se um conhecimento minucioso a seu respeito. As investidas comerciais e emocionais visam capturá-lo em todo seu ciclo de vida de modo a obter, no limite, a completa fidelidade do consumidor. Desse modo, procura-se gerenciar todas as suas experiências vividas, convertendo-as em ganho econômico. Do mesmo modo, no âmbito do trabalho, a introdução do trabalho imaterial fez com que o trabalho passasse a aderir ao trabalhador, que, como um capital humano, precisa zelar pelo aperfeiçoamento constante de suas competências e habilidades de modo a valorizar a si mesmo enquanto empresa. Cria-se assim uma nova maneira de se sentir e perceber o mundo, amplamente vinculada aos interesses corporativos.

Esta dissolução das fronteiras entre trabalho e consumo, entre material e imaterial está ligada à produção das emoções, explicitada acima em suas múltiplas estratégias que procuram solucionar a crise de produção de valor do modelo fordista. A produção das emoções caracteriza um momento histórico em que as separações entre mundo privado e esfera pública, entre indivíduo e massa consumidora desaparecem. Assim, o que também caracterizava a distinção entre drama, como forma e expressão dos conflitos de caráter privado, e teatro épico, como forma teatral da esfera pública, também se dissolve. O teatro da catarse e das emoções, que caracterizou o drama, já não se opõe ao teatro da razão (na era do seu gerenciamento técnico). A produção das emoções marca um novo estágio da Razão Administrada em que a lógica mais rigorosa coloniza todas as esferas conscientes e inconscientes do consumidor, gerindo a produção de valor por meio desta colonização. O que parece-me que a análise de Lehmann não menciona é que tal dissolução de fronteiras é atual e histórica e não eterna. O teatro pós-dramático não levaria em conta a distinção entre drama e épico não porque tais distinções não tenham existido ao longo da história, mas porque em tempos de produção e gestão de emoções a forma teatral expressaria tal associação entre lógica organizacional e sentimento, espaço público e privado. Se o teatro pós-dramático agrupa as manifestações teatrais que não mais levam em conta a construção de narrativas por meio da imitação, pode-se ler tal processo, paradoxalmente, como uma reafirmação da mímesis e da representabilidade, já que tal processo expressa, de algum modo, a organização social do novo mundo do trabalho. Lehmann, contudo, apresenta-nos processos formais que sintetizam e mimetizam determinados conteúdos históricos como se estivéssemos diante de essências formais esvaziadas, gravitando acima de uma realidade sem antagonismos. 
Estes antagonismos, que podem ser compreendidos a partir da relação entre forças produtivas, marcadas hoje pelo trabalho imaterial, e relações de produção dominantes, que podem ser caracterizadas como relações espetaculares - a produção de valor se realiza mediada por imagens transformadas em mercadorias -, modifica as formas espaciais e temporais da "vida danificada" . A redução da realidade ao fim em si mesmo da valorização capitalista do valor - a inversão que ocorre em seu interior entre meio e fim - transforma as potencialidades sociais num poder estranho e hostil que se contrapõe aos indivíduos. As relações entre os seres humanos parecem relações entre coisas mortas. Guy Debord desenvolve esta ideia para mostrar como a relação fetichista posta pelo capital alcançou no pós-guerra um grau de abstração ainda maior, na medida em que as coisas produzidas sob a forma mercadoria foram recobertas por imagens produzidas também sob a forma mercadoria: são essas imagens que apresentam, desde então, as relações sociais como uma realidade aparente compensatória que está à frente dos homens de maneira tão isolada como força alheia quanto às forças sociais nela inseridas. Não se trata de nenhuma "teoria da mídia": à medida em que a circulação de mercadorias e imagens prevalece como força estruturante e absoluta, o espaço vai se vendo esvaziado de sua materialidade: o espaço e o tempo parecem cada vez mais acelerados porque passam a se realizar exatamente onde há trânsito. As formas teatrais "pós-dramáticas", quando rompem com a narrativa linear e aproximam-se de novas tecnologias como a internet e o vídeo, expressam, de forma mediada, esta realidade.

Ao ignorar estes aspectos do tecido histórico contemporâneo na relação com o teatro pós-dramático, parece-me que Lehmann insurge-se, mais do que contra o "drama expandido", contra a tradição da crítica dialética:

Teatro pós-dramático pode ser concebido, não como um teatro que se encontra além do drama, sem relação alguma, mas muito mais como desdobramento e florescimento de um potencial de desagregação, de desmontagem, de desconstrução do próprio drama. Surge um fenômeno impensável hegelianamente, já que o mero ator individual situa-se acima do teor ético. (..) O impulso para a constituição do discurso pós-dramático no teatro pode ser descrito como uma sequência de etapas de auto-reflexão, decomposição e separação dos elementos do teatro dramático. ${ }^{273}$

Podemos identificar semelhanças entre o pós-dramático de Lehmann e o conceito de destruição/desconstrução de Heidegger, presente no livro Ser e verdade:

Trata-se de conquistar uma história universal em luta contra a própria história. (...) O ataque há de atingir a posição capital de

${ }^{273}$ LEHMANN, Hans-Thies, op.cit., p. 69-78. 
toda a história, com cuja conquista tudo se decide (...) esta posição capital (...) é a filosofia de Hegel. (...) Tudo isso são tentativas de término - esta vontade de originariedade, para uma fundamentação originária, para a simplificação, para a desconstrução. ${ }^{274}$

Em tal processo de desconstrução definido por Lehmann, as possíveis relações entre forma artística e história são deixadas de lado e as obras patinam no ar rarefeito das essências atemporais. Este solipsismo da crítica presente no seu livro sobre o pósdramático impede que identifiquemos facilmente os seus interlocutores e seus alvos de "ataque". É importante nomear tais interlocuções, para que entendamos o posicionamento filosófico estreitamente ligado à conceituação do pós-dramático e levantemos problemas ligados à utilização deste conceito para ler obras do teatro contemporâneo brasileiro, tais como Miopia:

A necessidade mecânica não é um fato: temos sido nós quem a temos introduzido no acontecer com nossa interpretação. (...) Só porque nós temos introduzido sujeitos agentes nas coisas, surge a aparência de que todo acontecer é a consequência de uma coação exercida sobre sujeitos - exercida por quem? Novamente por um agente. Causa e efeito - um conceito perigoso, na medida em que se pensa um algo que causa e um algo sobre o que se provoca um efeito. A necessidade não é um fato e sim uma interpretação. Se se tem compreendido que o sujeito não é nada que exerça um efeito senão apenas uma ficção, se seguem várias coisas. ${ }^{275}$

O rompimento com as relações de causa e efeito e com a noção de sujeito são traços da dissolução narrativa presente nas obras chamadas de pós-dramáticas, já que as características centrais do drama, a saber, ação, personagem e o conflito inter-subjetivo, sempre estiveram relacionadas às noções de indivíduo e de causalidade, presentes no drama e também na sua suspensão épica. O que o diálogo entre Nietszche e Lehmann revela, diálogo este que pode ser identificado no fragmento acima, é que se podemos afirmar que para a crítica de vertente dialética a qualidade de uma obra de arte é definida essencialmente pelo fato de esta se expor ou se esquivar ao inconciliável, representado pelas contradições sociais, e se assim podem ser consideradas profundas as obras que não mascaram as divergências ou as contradições, a dissolução de categorias como sujeito e causalidade implicam uma leitura crítica das obras teatrais em que as noções de tensão e de articulação de elementos são substituídas pela desconstrução homogênea. Ao obrigar as tensões a aparecerem, as obras admitem a

\footnotetext{
${ }^{274}$ HEIDEGGER, Martin. Ser e verdade. São Paulo: Vozes, 2007, p. 27-30.

${ }^{275}$ NIETZSCHE, Friedrich. Fragmentos Póstumos (1885-1889), Vol. IV. Madrid: Editorial Tecnos, 2007, p. 260.
} 
promessa de uma conciliação, mas dar forma aos antagonismos não os suprime nem os reconcilia. A desconstrução vista por Lehmann no teatro pós-dramático não se articula com um teor de verdade histórico de obras que expressam novas relações intersubjetivas e novas causalidades sociais e não apenas o vazio essencial do fim da história.

\section{VI.3. O pós-dramático negado pelo labirinto: contradições produtivas}

Contrariamente ao que propõe Lehmann, além de revelar transformações sofridas por uma "sociedade do espetáculo", a investigação da dissolução do épico presente em Miopia pode nos levar a camadas e estruturas sociais mais profundas, particulares do desenvolvimento capitalista brasileiro e periférico e a um conceito de obra teatral contemporânea bastante distinto do "pós-dramático".

O Teatro pós-dramático apresenta visões bastante contraditórias sobre o seu objeto. E é exatamente nas malhas destas contradições que podemos nos mover de maneira produtiva. Há um outro aspecto do livro de Lehmann que pode nos conduzir a percursos distintos dos já mencionados acima. Este aspecto está na justificação, contraditória à definição dada pelo próprio autor com relação ao caráter antinarrativo das obras analisadas por ele, do título de "pós-drama". Após o drama significaria que em determinadas obras o drama continuaria a existir como estrutura - mesmo que enfraquecida, falida - do teatro chamado de pós-dramático. Heiner Müller qualificou de maneira dialética o seu texto Descrição de imagem (Bildbeschreibung) como uma paisagem para além da morte e como explosão de uma lembrança numa estrutura dramática moribunda. Nesta vertente, contrária à desconstrução analisada acima, poderse-ia então descrever assim o teatro pós-dramático: os membros ou os ramos do organismo dramático, embora como material morto, ainda estão presentes e constituem o espaço de uma lembrança em irrupção. Assim, pode-se justamente falar de um teatro pós-brechtiano em Miopia que, em vez de não ter nada em comum com Brecht, tem consciência de que é marcado pelas reivindicações e questões sedimentadas na obra de Brecht mas não pode mais aceitar as respostas dadas por Brecht.

Em Miopia, a estrutura dramática do texto tornou-se moribunda no momento de sua encenação, em conflito com o espaço da usina de lixo. O espetáculo final utilizou o texto como a explosão de uma lembrança: as noções de personagem e indivíduo, de 
espaço, de tempo, de diálogo, de autoria, de narrativa e de contemplação por parte do público, presentes no drama, foram negadas pela encenação, mas mantidas como cadáveres no plano do texto. O texto teatral, "épico-dramático", permaneceu como testemunha e ruína deste processo de falecimento. Para evitar as aproximações aos universos do drama e do épico, por estarem presentes como ruínas, e também escapar ao termo "pós-dramático", por todos os motivos expostos acima incapaz de nomear a experiência de Miopia de forma característica, chamei nesta dissertação a forma teatral presente nesta peça de labiríntica.

A saída da casa e a realização das primeiras tentativas de montagem do texto na usina conduziram o grupo a novos conteúdos: o contato com as imagens de degradação e de exploração, tão marcantes no novo espaço, obrigaram o grupo a lidar com dois temas fundamentais, presentes apenas como subterrâneo do texto escrito: a forma mercadoria, que aparece no lixo como símbolo de uma sociedade que produz para destruir, e novas relações de trabalho, que, sob escombros ideológicos como "flexibilização", "ócio criativo" e "produção imagética", esconde formas de precarização e exploração do trabalho cada vez mais agudas. Estes conteúdos, característicos do estágio do capitalismo tardio, conduziram a encenação a procedimentos formais que negavam o texto e o assassinaram, gerando um espetáculo em que o personagem dá lugar a um emaranhado de desejos e vozes; em que o tempo é dilatado ou comprimido, de acordo com o tempo da tortura e do trabalho alienado; em que o diálogo dá lugar ao delírio; em que a narração dá lugar à montagem e ao acúmulo de detritos, como se a história fosse uma montanha de lixo; em que a autoria da peça não pode ser definida, já que o modo de produção foi colaborativo e as citações e pastiches acumulam o texto de inúmeras vozes; em que o espaço cênico, percorrido pelo público bombardeado por todas as informações citadas, toma a forma de um labirinto de espelhos sem fim. Quando, por exemplo, o público é conduzido ao longo da usina, seguindo o mesmo percurso que fazia o lixo, ao mesmo tempo são negadas as ideias de contemplação estética (o público vivencia uma experiência) e de narrativa (a fábula é quebrada o tempo todo pelo percurso do público, que se desloca e recolhe as cenas, como co-criador, em detritos por que passa durante o caminho). Ao se ver obrigado a construir um espetáculo em um espaço totalmente distinto do espaço para o qual o texto foi criado, o grupo, esmagado por novos conteúdos, esteve preso a seu próprio labirinto. Através de lento e longo processo de choque entre os recursos tradicionais presentes no texto e os esboços de encenação nascentes, o espetáculo foi sendo formado na medida 
em que as sucessivas tentativas de saída daquele impasse através de recursos dramáticos e épicos (presentes no repertório de todos os criadores) foram sendo negadas pelo mundo e momento histórico que a peça pretendia expressar. O texto, de material épico e também dramático (a sucessão da narrativa, por exemplo, é totalmente linear, configurando uma literal unidade de ação; já os recursos empregados, como coros e canções interrompem constantemente tal unidade, epicizando a ação) manteve-se, mas como cadáver morto pela encenação, presente enquanto sentido soterrado.

Talvez possamos encontrar nesta contradição entre texto e cena aspectos da formação social brasileira. Seguindo as pistas dos ensaios Crítica da razão dualista e $O$ ornitorrinco, de Francisco de Oliveira, seria possível, a título de hipótese a ser testada, distinguir, nesta contradição presente em Miopia a imagem metafórica do país como um ornitorrinco. O ornitorrinco deixou de ser subdesenvolvido, pois as brechas propiciadas pela Segunda Revolução Industrial, que faziam supor possíveis os indispensáveis avanços aos saltos que caracterizam os países atrasados, se fecharam. Nem por isso nosso ornitorrinco é capaz de passar para o novo regime de acumulação capitalista, para o qual lhe faltam meios. Trata-se, nas palavras do autor, de um quadro de "acumulação truncada em que o país se define pelo que não é; ou seja, pela condição subdesenvolvida, que já não se aplica, e pelo modelo capitalista, que não se alcança" 276

Talvez Miopia e o seu processo de criação apontem para a marca da "exceção permanente" no dia-dia brasileiro. Se não estivermos errados, é possível ver que a usina atolada de lixo abandonado contradiz a ordem da cidade moderna, que o trabalho informal executado por atores, diretor e técnicos contradiz o regime da mercadoria, que o patrimonialismo, a corrupção e a má gestão dos recursos públicos (obstáculos presentes a todo instante em um espaço administrado por uma subprefeitura e em um projeto teatral financiado por recursos públicos) contradizem a concorrência entre os capitais, e assim por diante.

Sob este ponto de vista, seria possível, e Miopia reuniria as ruínas deste testemunho, mesmo através das vivências mais corriqueiras, o reconhecimento e a sistematização do contraste entre o nosso cotidiano e a norma global, pela qual também nos pautamos. O salto dialético proposto por Francisco de Oliveira é a demonstração de que estas contradições não se baseiam em vestígios do passado, mas são sim partes

\footnotetext{
${ }^{276}$ OLIVEIRA, Francisco. Crítica da razão dualista e O ornitorrinco. São Paulo: Boitempo, 2005, p. 87.
} 
funcionais do desenvolvimento moderno do país, uma vez que contribuem para o baixo custo da mão de obra em que se apoia a nossa geração de riqueza. A precariedade das formas sociais do atraso não seria apenas uma herança arcaica que arrastaríamos como fardo, mas seria, isso sim, essencial à acumulação econômica que caracteriza nossas feições sociais. Nosso processo histórico seria assim formado por uma simbiose e uma organicidade, uma unidade de contrários, em que o chamado "moderno" cresceria e se alimentaria da existência do "atrasado".

Desde os trabalhos de Fernando Henrique Cardoso sobre o subdesenvolvimento nos países periféricos da América Latina, é possível demonstrar que a falência do projeto nacional-desenvolvimentista brasileiro não frustrara a industrialização capitalista da periferia, apenas o desenvolvimento em questão era dependente. O golpe militar de 64 veio solidificar uma nova dependência, que associava os grupos empresariais locais às multinacionais, redefinindo as relações entre interno e externo, seguindo padrões especificamente brasileiros de relações capitalistas de classe. Por este prisma arquivava-se o vocabulário das dicotomias (arcaico versus moderno, rico versus famélico etc.) e o subdesenvolvimento passava a ser visto como expressão do movimento internacional do capital - em suma, a herança do passado não era entrave à expansão do moderno, mas parte integrante do seu processo de reprodução. Antigo e moderno - que afinal são de todos os sistemas históricos, e portanto capitalistas em particular - realinhavam-se assim segundo uma outra lógica. Para os países colonizados e depois subdesenvolvidos, esta configuração é central, pois foram incorporados ao mundo moderno, leia-se ao mercado mundial, na qualidade de econômica e socialmente atrasados (fornecedores de matéria-prima e trabalho barato). Seguindo agora Paulo Eduardo Arantes, a ligação destes países com o novo se faz através do atraso, que assim se torna estrutural, e em lugar de se extinguir, se reproduz, como atesta a industrialização recente dos países africanos. Revistas as coisas deste ângulo, o tradicional torna-se pura e simplesmente uma das figuras do moderno:

Isso posto, não está anulada a impressão de dualidade e contradição que o país não cessa de renovar. $\mathrm{O}$ antigo e o novo continuam em presença um do outro - é o que parece mostrar a experiência social de todos os dias, sobretudo quando filtrada pela forma estética muda apenas o plano de sua relação. Somos de fato produto do movimento internacional do capital, mas embora este se desenrole em escala mundial, vai compondo elementos que são diferentes e assimétricos; distinguimo-nos assim do padrão geral na medida em que a primitiva exploração colonial está na base da articulação entre sociedades dependentes e dominantes. Mas a que se resume a singularidade do país senão a essa coexistência, sistemática, 
descompartimentada, de herança colonial e presente capitalista? Acrescida do fato de que a referida herança também era um legado de formas pretéritas da expansão capitalista. ${ }^{277}$

Ainda seguindo a nossa hipótese inicial, essa contradição cotidiana expressaria a nossa formação social e caracterizaria os vetores básicos da experiência brasileira presente em Miopia. A justaposição de dois processos de criação contraditórios, com temas e espaços cênicos opostos, e a realização de uma encenação que arruina o texto por dentro, mantendo-o como cadáver exposto, mas sem cansar de negá-lo, marcariam um espetáculo que não pode ser simplesmente chamado de pós-dramático, nem de épico e nem de dramático. A definição do pós-dramático, do drama puro e do teatro épico voltada exclusivamente para a experiência europeia, notadamente a alemã, não dá conta de um espetáculo que propõe a morte do drama e do épico sob uma realidade de capitalismo periférico.

Em Miopia, a contradição entre antigo e contemporâneo dar-se-ia, à primeira vista, no plano da forma do espetáculo. Ao contrário da experiência pós-dramática descrita por Lehmann, o texto dramático-épico, criado pelo próprio grupo, contemporaneamente, foi conservado no espetáculo: o texto era dito, mas imediatamente negado pela forma labiríntica da encenação. A análise da cena seguinte pode ser bastante reveladora a este respeito:

\section{UMA ASSEMBLEIA EM MOVIMENTO}

No caminhão, ocorre uma estranha Assembleia.

ROSA - É preciso ter calma neste momento, camaradas, é preciso ter calma.

FAUSTO - Eles vão nos atirar ao mar! Eles vão nos afogar!

BELMIRO - Eles querem nos torturar! Eles farão experiências cientificas com nossos corpos ainda vivos e quentes! Eles colocarão vidro em nossas veias, aço fumegante em nossos olhos, retirarão, com pinças coloridas, pedaços de nossos cérebros em funcionamento. Somos cobaias a serviço da ciência do capital!

FAUSTO - Seremos deportados, seremos entregues a Hitler. E eu? Eu não tenho nada a ver com isso! Eu não odeio Vargas! Eu não odeio Hitler! Eu não odeio Benito Mussolini! Pelo contrário, muito pelo contrário! Stalin é um genocida! Roosevelt é um genocida! E vocês, vermelhos, você todos me enfiaram aqui, num caminhão imundo, como gado podre!

ROSA - É preciso serenidade neste momento. Nós não sabemos o que aconteceu.

\footnotetext{
${ }^{277}$ ARANTES, Paulo Eduardo. Sentimento da Dialética. São Paulo: Paz e Terra, 1992, p. 38.
} 
FAUSTO - Eu sei! Vocês tiraram a paciência do presidente Vargas, ele cansou do golpismo dos russos! E agora eu estou aqui, preso, entre subversivos e criminosos!

ROSA - Nós somos todos um só agora... qual a sua graça, camarada?

FAUSTO - Fausto Falstaff, este é meu nome.

ROSA - Temos que nos unir, caro Fausto, não adianta desespero. Não adianta forçar as portas, companheiros. Nós estamos presos e em movimento. Eles vão nos jogar em algum lugar. Já ouvimos dizer que não é a primeira vez que isto acontece quando o governo precisa fazer uma limpeza na cidade.

BELMIRO - Foi aquele ali. Ele é o carroceiro. Ele matou o mendigo ontem.

ROSA - (Luz em Fausto). O nome dele é Fausto, foi provocado. Reagiu. Ele é perigoso. Ele diz coisas muito acertadas. Numa hora dessas não dá para ser delicado e nem covarde. Já ouvi muitos dizerem que ele acertou, que não há lugar para inferiores no meio do deserto em que nos encontramos.

BELMIRO - E você concorda com ele, Rosa? Isso é fascismo!

ROSA - Fala baixo, Belmiro. Eu não concordo. Eu não discordo. Nós precisamos do Fausto. Ele sabe falar a língua dos excluídos, dos exilados, dos desvalidos. Eles não nos entendem, ainda.

BELMIRO - Aqui?

ROSA - (para Fausto) Podemos nos sentar aqui? (Um fósforo ilumina Rosa e Belmiro, sentados ao lado de Fausto). ${ }^{278}$

A cena representa uma assembleia, tema bastante comum à tradição do teatro épico: neste caso, a assembleia reúne, ao invés de trabalhadores organizados, desempregados. Ao ser escrita, a partir de improvisações realizadas ainda no período de ensaios abrigado pela casa, a representação imaginada contava com o modelo tradicional do repertório épico: diálogos tensos, em que uma espécie de mesa diretiva conduzia a assembleia, que era acompanhada de exclamações e interjeições dos demais participantes. A cena ocorreria, incialmente, na chegada/despejo dos trabalhadores em algum lugar ermo do Mato Grosso.

Quando o texto passou a ser ensaiado na Usina, por uma questão trivial de ausência de local determinado para realizar a cena - já havíamos determinado um percurso do público e das cenas pela Usina e esta assembleia estava literalmente sem lugar definido para acontecer - surgiu a proposta de realizar uma assembleia em movimento, realizada durante o percurso dos desempregados até o seu despejo. Este caráter de movimento acabou definindo o conceito de encenação para a assembleia e sua construção determinou a existência do texto como cadáver na versão final da cena.

${ }^{278}$ ALMEIDA, Ligia Marina, DELMANTO, Ivan, FARIA, Fernanda, et al. Miopia. Inédito, 2006, p. 5. 
O espaço em que a assembleia ocorria já determinava inúmeros outros sentidos à situação: um baú de caminhão, estreito, em que se amontoavam os 30 espectadores e os atores participantes. $\mathrm{O}$ baú não possuía iluminação e permanecia a cena inteira com as portas fechadas, em escuridão total. A partir de um trabalho de musicalização desenvolvido com o diretor musical da peça, os atores vinham treinando percussão para algumas canções utilizando apenas caixas de fósforos. Acabei incorporando o exercício à encenação: o ritmo dos diálogos era entrecortado por enormes pausas e pelo som das caixas de fósforo. A iluminação da cena passou a ser executada com os fósforos, o que dava um caráter de apresentação de relâmpagos à situação: a cada riscar de fósforos uma fala era dita e um rosto, um fragmento veloz de ação podia ser visualizado, antes que tudo caísse novamente na escuridão. Esta sucessão de relâmpagos dissolveu qualquer possibilidade de construção de imagem coletiva. Para completar, durante as primeiras improvisações no caminhão, os atores batiam nas paredes de metal do baú, inicialmente com a intenção de fugir. Retiramos este aspecto psicológico às batidas e passamos a explorar ritmos e sons que eram executados com o objetivo de rasgar as palavras, fragmentando ainda mais tudo o que era dito. $\mathrm{O}$ resultado era uma cena em que fantasmas falavam um texto quase incompreensível, em que algumas palavras podiam ser compreendidas, mas que a alegoria do isolamento, do espaço exíguo e escuro, dos rostos e dos sons fantasmáticos sem objetivo claro, era mais significativa do que a narrativa contada pelo texto. $\mathrm{O}$ texto permaneceu em cena, mas como cadáver produzido pela encenação. O público podia entrar em contato com o seu odor apodrecido, com os seus aspectos em via de aniquilamento, e não com a sua inteireza épica.

Tal forma labiríntica em Miopia alimentou-se exatamente do "atraso" do texto: os paradigmas épicos, traços de um outro estágio do capitalismo, ao serem negados para surgirem como detritos, serviam à imagem caótica, à multiplicidade de desejos e de formas de exploração, marcas da forma mercadoria expandida e potencializada ao absoluto, traços do estágio mais recente de reprodução do capital.

Se pensarmos em aspectos já mencionados sobre este estágio recente, a administração das emoções, o divíduo como consumidor, a produção crescente de mercadoria como dejeto, o poder biopolítico exercido sobre os corpos, talvez seja possível perceber na forma da cena fraturada, construída sobre o cadáver de um texto que trata de uma assembleia política, a expressão destes aspectos, alegorizados pelo confinamento em movimento contínuo; pelas subjetividades assujeitadas, incapazes de 
articulação de um discurso próprio; pela escuridão permanente, rasgada por traços de luz insuficientes etc. $\mathrm{O}$ acúmulo de texto e encenação em ruínas, criada com material de dejeto, fósforos, um baú de caminhão vindo de um ferro velho, era capaz de criar estes novos sentidos: a leitura do texto, apenas, ou a utilização das mesmas imagens, mas sem o combate em contradição permanente com o texto, não gerariam a textura de dramaturgias capaz de configurar estes sentidos.

E se nos voltarmos para o que a forma artística do labirinto conserva em segredo, veremos, no processo de criação do espetáculo, inúmeras contradições, aparentemente irreconciliáveis, unirem-se para gerar o labirinto do resultado final (reunião quase infinita de contradições, à imagem da realidade brasileira): a casa e a usina, os anos Vargas e o capitalismo atual, a realidade dos criadores, todos membros da pequena e média burguesia do centro da cidade, e a realidade dos trabalhadores da usina e da comunidade habitante da região, público principal do espetáculo e das oficinas que envolveram seu processo de criação. Apenas como reunião destas contradições a peça (e sua forma característica) foi possível. O labirinto, testemunha de nossas agruras mais recentes, depende do que nega, destrói mas conserva, como cadáveres em sacos de lixo: a forma dramática e épica justapostas, alegorizando uma realidade brasileira que é prémoderna, moderna e ultramoderna, feixe de contrários. 


\title{
Conclusão: O labirinto como constelação saturada de crises
}

\begin{abstract}
a beleza que dura é um objeto do saber. Podemos questionar se a beleza que dura ainda merece esse nome; o que é certo é que nada existe de belo que não tenha em seu interior algo que mereça ser sabido. A filosofia não deve duvidar do seu poder de despertar a beleza adormecida e esquecida como ruína na obra ${ }^{279}$
\end{abstract}

Desenvolvemos ao longo desta dissertação o conceito de labirinto, tentativa de nomear o material artístico presente em Miopia que, a nosso ver, deslocado na presente realidade brasileira, não se encaixaria nos paradigmas do teatro épico, que foram os provocadores iniciais do processo criativo da peça, nem no modelo de teatro pósdramático, que vem sendo muito utilizado para descrever grande parte da atividade teatral contemporânea.

Levando em conta alguns dos passos de Theodor Adorno, em sua Teoria Estética, chegamos à conclusão de que o conceito capaz de recuperar e fazer avançar o nosso trabalho de crítica sobre o processo de criação de Miopia, em sua dialética de forma e conteúdo, seria o de material:

\begin{abstract}
De acordo com uma terminologia já quase generalizada nos gêneros artísticos, se chama assim aquilo a que se dá forma. $\mathrm{O}$ material não é o mesmo que o conteúdo. (...) Pelo contrário, o material é aquilo com que os artistas jogam: as palavras, as cores e os sons que se lhes oferecem, até chegar a conexões de todo o tipo e a procedimentos desenvolvidos para o todo; portanto, também as formas podem ser materiais, tudo o que se apresenta aos artistas e sobre o que eles têm que decidir. ${ }^{280}$
\end{abstract}

A seleção do material, o emprego e a limitação em seu emprego é um momento essencial da produção. Só uma parte extremamente pequena do material disponível abstratamente é utilizável de uma maneira concreta, sem colidir com o estado geral do espírito. O material não é um material natural nem sequer quando se apresenta para os artistas como tal, senão que é completamente histórico.

As consequências desenvolvidas por Adorno ressaltam este processo: "Com isso, o material deixa de ser mera possibilidade para se apresentar, em certa medida, como algo já pré-formado (...)

\footnotetext{
${ }^{279}$ BENJAMIN, Walter. Origem do drama barroco alemão, p. 204.
}

${ }^{280}$ ADORNO, Theodor. Teoria estética. Madrid: Akal, 2004, p. 199. 
mesmo quando hoje se escreve um acorde conhecido há séculos, ele não tem o mesmo sentido de antes (...) as possibilidades da composição já contêm em si os elementos da história." O material deixa de ser entendido como o conjunto total dos meios de expressão para ser o resultado da consciência das possibilidades de expressão, tanto na criação quanto na audição de uma obra. Por isso, as "possibilidades" são limitadas, já que a expressão dos meios é histórica, e não natural. A ideia de sedimentação histórica dá sentido não apenas ao material, mas ao próprio sentido. Não há acordes neutros em expressão. ${ }^{281}$

Podemos ler, nessa transformação do conceito de material sofrida ao longo da história, algo sobre o processo de construção de Miopia. Inicialmente o grupo partiu de um estudo sobre encenadores dialéticos e sobre o teatro épico partindo do princípio de que este material seria formado por um conjunto total de meios de expressão, disponível para serem experimentados e utilizados, cabendo aos artistas a tarefa de reorganizá-los e, em menor medida, de recriá-los, em função das questões e angústias do seu próprio tempo.

No entanto, o processo de pesquisa e de criação revelou que este material não poderia ser livremente apropriado, a historicidade deste mesmo material restringia, por si só, suas possibilidades de incorporação, pré-formando-o. Este impasse surgiu, neste processo de autoria conjunta, quando o espaço cênico transferiu-se da casa para a Usina: a encenação teve que se haver com um texto criado inteiramente a partir dos paradigmas, em estado irrefletido, do teatro épico, atravessados ainda, em menor medida, por alguns elementos dramáticos.

Os testes desse texto no novo espaço revelavam que as questões que o grupo gostaria de abordar, seus conteúdos, não encontravam como serem expressas. Este emudecimento do conteúdo mostrava, mesmo que de maneira inconsciente, que a forma épica possuía por si mesma conteúdos sedimentados e que o material e os procedimentos relacionados a esta forma, o estranhamento, a fragmentação, a narração, o coro, também continham cifradas em si as características de um mundo que não existia mais.

Esse impasse não foi resolvido: permanece irrealizado no arruinado tecido dramatúrgico da peça e esta impossibilidade de utilização do material selecionado pelos criadores gerou a lógica labiríntica que rege a organização de escombros em Miopia,

\footnotetext{
281 ALMEIDA, Jorge. Crítica dialética em Theodor Adorno. Cotia, São Paulo: Ateliê Editorial, 2007, p. 292.
} 
revelando, paradoxalmente, nessa sua derrota na relação com o material, índices da realidade histórica contemporânea. Insistindo, até o limite, em utilizar este material barrado em sua historicidade, o grupo tensionou a pré-formação dos "procedimentos dialéticos" do teatro épico tradicional até o ponto de sua explosão, dando arquitetura ao labirinto.

Temos falado nesta dissertação, mesmo que não nomeada explicitamente, de uma concepção particular que envolve a relação entre forma e conteúdo, que faz deste conceito de material o ponto central da dialética entre o artista, a obra e a sociedade. A articulação mediante a qual a obra de arte obtém sua forma admite, em certo sentido, sua derrota. Esta busca pela unidade sem fratura nem violência da forma e do formado, tal como está presente no ideal de forma, foi perseguida pelos criadores de Miopia que tentaram, inicialmente, à maneira de Procusto, mutilar o material do teatro épico para tentar formar os conteúdos advindos do capitalismo tardio.

Vimos, ainda, que o material labiríntico de Miopia poderia ser caracterizado por uma crescente dissolução, durante o processo criativo, dos procedimentos e conteúdos épicos iniciais, transformando-os em cadáver exposto na encenação: tal convivência entre material épico morto e um acúmulo de alegorias sob a forma de ruínas, gerando um resultado teatral de sentido barrado, foi chamado, durante a tentativa de análise crítica empreendida neste trabalho, de labirinto e teve sua lógica descrita a partir desta denominação.

Miopia, que por seu caráter de devir permanente tomava a feição de diversas versões ao longo de cada apresentação, não foi considerada uma obra, no sentido que é empregado na análise do modernismo realizada por Adorno. Por isso, teve seu teor de verdade depositado não na ausência de sentido, mas na sua capacidade de mimetizar, neste seu movimento permanente, os novos processos históricos que emergiram após a ascensão e a crise do drama e do teatro épico.

Quanto à caracterização sobre o "teor de verdade", partimos também da Teoria Estética: as obras de arte seriam como enigmas que "ao exigirem solução, remetem para o teor de verdade, só acessível mediante reflexão". Este mundo próprio e enigmático, criado pelas obras de arte, seria capaz de exprimir o que de outra forma não poderia ser dito sobre a realidade e, nesta expressão mediatizada, encontraríamos o seu teor de verdade.

Mas, na forma labiríntica de Miopia, a insistência na multiplicidade e na justaposição de sentidos que constitui o labirinto gerou por vezes enigmas em que as 
chaves pareciam terem sido roubadas. O labirinto Miopia conduziu seus espectadores ao impasse ou ao silêncio diante de alegorias acumuladas de forma quase incompreensível, diante de uma verdade emudecida, soterrada, que necessitava ser escavada.

O interesse em Miopia estaria em uma utilização desenfreada do material, mas não como "opções artísticas vivas" e sim exatamente como arte morta. Miopia assume a morte do material do teatro épico e cria precisamente por meio das ruínas e dos órgãos falidos deste material, sem procurar a todo custo revivê-lo, como, segundo Artur Danto, faz a arte contemporânea.

Danto argumenta, em Após o fim da arte, que a arte contemporânea, ao contrário dos modernistas, nada tem contra a arte do passado, nenhum sentimento de que o passado seja algo de que é preciso se libertar e mesmo nenhuma percepção de que tudo seja completamente diferente, como em geral a arte da arte moderna. Seria parte do que define a arte contemporânea que a arte do passado esteja disponível para qualquer uso que os artistas queiram lhe dar: "O que não lhes está disponível é o espírito em que a arte foi realizada". ${ }^{282}$

Isso porque a percepção básica do espírito contemporâneo teria sido formada "no princípio de um museu em que toda a arte tem seu devido lugar, onde não há critério $a$ priori sobre que aparência esta arte deve ter, e onde não há nenhuma narrativa à qual o conteúdo do museu tenha de se ajustar completamente. Os artistas de hoje não veem os museus como repletos de arte morta, mas como opções artísticas vivas". ${ }^{283}$ A visão de Danto estaria impregnada desta concepção do material como meios neutros de expressão disponíveis em liberdade ao artista se ele não mencionasse que o que não está disponível é o "espírito em que a arte foi realizada". Este espírito são os sedimentos históricos que limitam a liberdade de escolha do artista e restringem a livre utilização do material. Levar em conta que não há mais o "espírito em que a arte foi realizada" foi em Miopia assumir que tal espírito está morto, sem desistir de utilizá-lo, mas tomando-o como material arruinado.

Ao mesmo tempo, ao se utilizar insistentemente do lixo e das mercadorias descartadas, sem qualquer tratamento "artístico", em aberto diálogo com o espaço cênico da Usina, Miopia expunha também o cadáver de um material de outra espécie, estritamente relacionado às artes visuais contemporâneas e à performance:

\footnotetext{
${ }^{282}$ DANTO, Arthur C. Após o fim da arte. São Paulo: EDUSP, 2010, p. 7.

${ }^{283}$ Idem, ibd.
} 
que as obras de arte podem ser imaginadas, ou de fato produzidas, fazendo com que se pareçam exatamente com meras coisas reais, que não têm nenhuma pretensão à condição de arte, justamente porque essa condição impossibilita a definição de obras de arte com base em certas propriedades visuais que elas possam ter. ${ }^{284}$

A utilização de objetos não trabalhados para serem "arte", para converterem-se em cenário, adereço ou figurino, mas sim aproveitados em sua destruição e descarte, estaria restrita ao universo da arte contemporânea se estes não fossem parte de uma obra assumidamente teatral, em que estruturas como personagem e a narrativa, garantem a permanência do espaço ficcional, mesmo que como ruína. O material advindo da arte contemporânea surge assim no labirinto também como cadáver e ganha, ao mesmo tempo, sentido artístico e não-artístico.

Mas como este material-cadáver foi apreendido pelo público?

A preocupação sobre esta relação entre o público (ou leitor) e a obra artística também foram preocupações de Roberto Schwarz, quando refletiu sobre a atualidade de Brecht:

Pensando no público em que se inspiravam as suas inovações, e que elas por sua vez estilizavam, Brecht se refere a "uma assembleia de transformadores do mundo" - uma companhia peculiar, de caráter proletário, amiga sobretudo da insatisfação bem formulada, do espírito crítico e de propostas subversivamente materialistas e práticas. Se não for uma ilusão retrospectiva, esse espectador sob medida para o teatro político existiu durante um curto período, nuns poucos lugares, ligado a condições especiais, que merecem reflexão. Era o resultado da confluência entre os "teatros livres" - um experimento importante, filiado à literatura naturalista, no qual a contribuição voluntária dos associados afastava da cena as considerações mercantis e o ponto de vista oficial - e o avanço histórico das organizações operárias autônomas ${ }^{285}$.

Haveria, para Schwarz, uma aposta clara do teatro brechtiano na desnaturalização das condições sociais, no esclarecimento dos indivíduos diante do obscurantismo da sociedade capitalista, em termos marxistas, na crítica da ideologia. Tratar-se-ia de encenar visando desvelar criticamente um conjunto de ideias e comportamentos enfeitiçados pelo fetiche da forma mercadoria.

\footnotetext{
${ }^{284}$ Idem, p. 19.

${ }^{285}$ SCHWARZ, Roberto. “Altos e baixos da atualidade de Brecht.” In: Sequências brasileiras. São Paulo: Companhia das Letras, 1999, p. 126-127.
} 
Tal material, contudo, não encontraria, na periferia leste de São Paulo, espaço cênico de Miopia, de forma imediata seus destinatários originais. Os operários encontram-se atomizados num mercado de trabalho que os mobiliza pela insegurança, precariedade e dessolidarização avançada. Os teatros não são mais livres, movimentamse no horizonte das políticas governamentais (leis de fomento, renúncia fiscal de empresas, programas de incentivo a cultura de estatais e outros), sendo que os governos são totalmente dependentes da valorização financeira internacional.

Embora não formada pelos especialistas a que se destinava o teatro épico de Brecht, a experiência de Miopia revelou, salvo engano, que este público, mesmo esvaziado pela indústria cultural, encontrou no outro sentido, realizado pela peça, de desartificação da arte, ou seja, por seu caráter de processo e de "não-obra" , a possibilidade de se relacionar com uma espécie de experiência inabitual e extracotidiana.

Estaríamos aqui diante do conceito dialético, empregado por Adorno, de desartificação da arte. A desartificação da arte poderia ser compreendida por meio de dois sentidos antagônicos, mas complementares. Antes de tudo, como uma projeção, por parte desse público culturalmente expropriado, da sua nulidade interior sobre as obras, degradando-as por não se colocar à sua altura:

Enquanto tábula rasa das projeções subjetivas, a obra de arte é desqualificada. Os polos de sua desartificação são: que ela se torna tanto coisa entre coisas quanto veículo da psicologia do observador. O que as obras de arte não dizem mais, o observador substitui pelo eco padronizado de si mesmo, que ele ouve delas. ${ }^{286}$

O silenciamento das obras adviria assim da incapacidade de sua interpretação pelas massas, de modo que a desartificação poderia ser entendida também como incompreensão das manifestações estéticas em virtude de uma projeção depauperada, implícita na referência ao "eco padronizado de si mesmo".

No entanto, as transformações empreendidas pelas forças produtivas sociais são refletidas nas obras de arte por uma proporcional incorporação de novos procedimentos técnicos. A desartificação da arte estaria assim em consonância com sua "tendência tecnológica", o que seria um primeiro aceno concreto para a possibilidade de que esta arte não fosse apenas um reflexo da incompreensão do público esvaziado pela indústria cultural, mas também abrisse caminho para uma incorporação, através da retradução em

${ }^{286}$ ADORNO, Theodor. Teoria estética. Madrid: Akal, 2004, p. 30. 
linguagem artística, de elementos presentes no mundo administrado, tendo em vista resultados críticos.

O público de Miopia teve, essencialmente, a participação de moradores da região e de estudantes e praticantes de teatro que se dispunham a empreender o grande deslocamento que envolvia a saída de suas regiões de origem para o extremo leste da cidade e que também estavam dispostos a encarar, em um segundo momento, as grandes filas que se formavam no metrô Carrão reunindo os espectadores interessados em se deslocar à Usina com o ônibus da peça. O ônibus gratuito e a temporada realizada integralmente de maneira gratuita tornaram a presença deste público possível. Para compreender melhor esta situação, sob o viés crítico e produtivo da desartificação, vale a pena mencionarmos, ainda que de passagem, o contexto político-cultural da Lei Municipal de Fomento ao Teatro.

Em meio a um panorama de crise econômica e cultural absoluta, um movimento político que reuniu diversos grupos teatrais em São Paulo conseguiu a aprovação da Lei Municipal de Fomento ao Teatro. A produção de Miopia, mesmo estando baseada no lixo e em materiais descartáveis, foi realizada graças a este financiamento.

\begin{abstract}
A bandeira de luta por políticas públicas para a cultura no Brasil resulta de uma análise muito precisa do discurso neoliberal que acompanhou as práticas inauguradas por Collor, intensificadas por Fernando Henrique e agora incorporadas por Lula. A própria política "intocável” de superávit fiscal nada mais é que a declaração de que os interesses do capital financeiro estão acima de todos os demais. Leis de renúncia fiscal fazem parte deste processo. Consistem em transferir ao próprio capital a prerrogativa de definir políticas para a arte e a cultura. ${ }^{287}$
\end{abstract}

Neste contexto, no final dos anos 90, surge um movimento de grupos e companhias teatrais paulistanas organizando-se contra o modelo de política cultural vigente. A reunião dos grupos: Tapa, Parlapatões, Companhia do Latão, Teatro da Vertigem, Folias D'arte e Pia Fraus constituíram o primeiro núcleo do Arte contra a Barbárie. Outros coletivos foram posteriormente agregados a esta célula inicial, que passou a reunir-se constantemente na batalha por uma política cultural estável para a atividade teatral. O cerne da reivindicação do Arte Contra a Barbárie era a obtenção de

${ }^{287}$ COSTA, Iná Camargo e CARVALHO, Dorberto. A luta dos grupos teatrais de São Paulo por politicas públicas para a cultura. São Paulo: Cooperativa Paulista de Teatro, 2008, p. 19. 
uma política cultural estável, democrática e transparente para a atividade teatral. Como consta no segundo manifesto publicado pelo movimento:

Voltamos a reafirmar a necessidade de se superar o estado de indigência, de guichê, de improviso, da visão economicista para se consolidar uma produção cultural diversa, múltipla e democrática que possa contribuir para a alimentação do imaginário e da sensibilidade do cidadão brasileiro.

Após três anos de combate por uma política cultural estatal, em dezembro de 2001 a Câmara Municipal aprovou a Lei de Fomento ao Teatro. Esta conquista política assegurou a grupos teatrais um significativo ganho material e simbólico: a possibilidade de exercer uma prática artística que não se submetesse ao mercado. Segundo Iná Camargo:

\footnotetext{
A lei não contempla projeto só para a montagem, produção eventual de espetáculo que depois vai disputar espaço de distribuição no mercado convencional ou no mercado alternativo. Ela se destina a trabalhos que estão fora do mercado, isto é, à produção não-comercial.
}

E nesse sentido, a implantação da Lei de Fomento trouxe consequências do ponto de vista social, político, pedagógico e estético, modificando parte do teatro paulistano. Muitos grupos, e não só a II Trupe de Choque, passaram a ocupar espaços não convencionais para realizar suas pesquisas artísticas, re-significando o espaço público, estabelecendo pesquisas artísticas continuadas que contaminaram todas as regiões da cidade.

Em Miopia, para a experiência do público no labirinto, este caráter gratuito da peça também constituiu-se como parte integrante da forma artística realizada: o fato de não estabelecer com seus espectadores o diálogo baseado na forma mercadoria, deslocava as expectativas da recepção da peça para uma experiência para além do produto. Este caráter experimental e desartificado da peça esteve o tempo todo garantido por seu distanciamento de uma forma acabada a ser consumida para satisfazer os desejos de seu público.

No entanto, o caráter labiríntico de tal experiência, por outro lado, dificultava o exercício da reflexão sobre este processo de instabilidade, conduzindo o espectador e os objetivos dos criadores de Miopia a um impasse. Ao mesmo tempo que pretendia-se que o público fosse também criador da peça, sua estrutura labiríntica dificultava esta consumação criativa e esta atividade exigida do público. Esta ausência de saída permaneceu como característica definidora do labirinto Miopia. 
O labirinto em Miopia esteve exposto, cena a cena, beco a beco percorrido na Usina, ao abismo do fracasso, ou ao vazio da incompreensão total. Podemos afirmar, a partir da narrativa tortuosa que tecemos neste trabalho sobre o processo de construção da peça, que, em relação aos seus conceitos e intenções iniciais, Miopia foi um fracasso.

A etapa inicial de pesquisa realizada pela II Trupe, que teve a duração de mais de dois anos, materializou suas conclusões na criação de um texto teatral que procurava realizar uma atualização dos procedimentos épicos investigados. Contudo, esta versão de texto foi negada pela encenação da peça, que construiu sobre a transparência narrativa da dramaturgia inicial um labirinto de alegorias e imagens de sentidos múltiplos, em direções distintas às propostas pelo material inicial.

Mas, precisamente nesta sua fraqueza, nas suas lacunas, nas suas esquinas sem saída e nas suas inúmeras crises a peça constitui-se inicialmente como crítica do sucesso. Crítica ao parâmetro do sucesso ditado pelas regras da forma mercadoria e de seu consumo, baseado na satisfação dos desejos e expectativas do público.

Neste perambular caótico do público pelo labirinto constituiu-se uma zona fronteiriça, constelada de crises, entre o sentido e o não-sentido. Tal zona poderia aproximar-se da descrição da Zona enigmática realizada por Arkadi e Boris Strugatsky na novela Roadside picnic ${ }^{288}$ : a Zona é uma área mágica e incompreensível, de espaço radicalmente distinto - um espaço de outridade situado além da Lei, um Chernobyl em que todos os desejos são realizados.

Há nessa Zona objetos inusuais: objetos enigmáticos como os vazios e o sopro ardente, junto com objetos de inestimável valor de uso, como baterias permanentemente carregadas - que são de inestimável valor para o complexo industrial militar. Este labirinto, espaço de outridade em relação aos pontos de partida iniciais de pesquisa, a estética de encenadores que transitaram entre o drama e o teatro épico, foi construído com o auxílio destes objetos inusuais: as ruínas do tecido urbano e do consumo, na forma de objetos e de personagens transformados em produtos, em mercadorias descartáveis, em alegorias criadas a partir do inacabamento e do desmoronamento, da generalizada ruína: “ a obra de arte (...) lhes aparecia, por outro lado, como o resultado

${ }^{288}$ STRUGATSKY, Arkady and STRUGATSKY, Boris. Roadside Picnic. London: Penguin, 1979. 
calculável de um processo de acumulação, as duas perspectivas são tão facilmente conciliáveis como, na consciência do alquimista, a 'obra' miraculosa com as sutis receitas de sua teoria." 289

Esta acumulação, resultado de um processo calculável presente nas obras de arte barrocas, dizia respeito à sobreposição de escombros, organizada para Benjamin, entretanto, com a meticulosidade de um processo alquímico:

A fachada partida, as colunas despedaçadas, têm a função de proclamar o milagre de que o edifício em si tenha sobrevivido às forças elementares da destruição, do raio e do terremoto. Em sua artificialidade, essas ruínas aparecem como o último legado de uma Antiguidade que no solo moderno só pode ser vista, de fato, como um pitoresco monte de escombros (...). Pode-se estudar a evolução dessa tendência na prática engenhosa dos artistas renascentistas de localizar nas ruínas de um templo antigo as cenas do nascimento e da adoração de Cristo, e não numa manjedoura (...). Em [Domenico] Ghirlandaio [pintor florentino renascentista, 14491494] essas ruínas eram ainda acessórios, impecavelmente preservados. Agora, transformam-se em fins em si, nos presépios coloridos e plásticos, como bastidores pitorescos ilustrando a transitoriedade da pompa. ${ }^{290}$

Também em Miopia a presença da ruína não é ocasional, mas fator de construção do labirinto. Seu sentido, no entanto, não é desmascarar a "transitoriedade da pompa", mas testemunhar a produção de subjetividades e de uma organização social reificadas, construídas sobre a forma mercadoria, que deve transformar-se em dejeto para garantir a sobrevida da destruição constante:

Há em toda poesia uma contradição essencial. A poesia é multiplicidade triturada e incendiada. E a poesia, que estabelece a ordem, suscita primeiro a desordem, a desordem dos aspectos incendiados; provoca o choque dos aspectos que leva a um ponto único: fogo, gesto, sangue, grito. Trazer a poesia e a ordem a um mundo cuja existência já é um desafio à ordem, é levar à guerra e à permanência da guerra, é fundar um estado de crueldade incidida, é suscitar uma anarquia sem nome, a anarquia das coisas e dos aspectos que acordam antes de soçobrarem de novo e se fundirem na unidade. Mas aquele que acorda esta anarquia perigosa é sempre a sua primeira vítima. E Heliogabalo é um anarquista que começa por devorar-se a si mesmo e acaba por devorar os seus excrementos. ${ }^{291}$

\footnotetext{
${ }^{289}$ BENJAMIN, Walter. Origem do drama trágico alemão. Lisboa: Assirio \& Alvim, p. 200.

${ }^{290}$ BORINSKI, Karl apud BENJAMIN, Walter. Op.cit., p. 200. Cf: a obra do pintor italiano Domenico Ghirlandaio (1449-94): A adoração dos magos (1487). Galleria degli Uffizi. Florença. Itália. (http://www.abcgallery.com/G/ghirlandao/ghirlandaio.html).

291 ARTAUD, Antonin, Heliogabalo ou o Anarquista Coroado, Assírio e Alvim, 1982, p.80.
} 
Miopia tomou, no início de sua criação, como pressuposto a busca por procedimentos capazes de revelar uma possível nova ordem do sistema capitalista, através de uma forma que pudesse ser transparente na exposição de um pensamento crítico sobre a realidade. Se tomarmos tal pensamento crítico caracterizado pelo movimento de um processo decorrente da contradição e das suas sucessivas figuras de resolução e de recomposição, poderemos aproximá-lo do conceito de mímesis, agora formulado por Lukács, que via na mímesis dos grandes autores realistas a "conformação das contradições da situação social dada em cada caso" como sendo capaz de plasmar o inefável:

\begin{abstract}
A inefabilidade no sentido de Goethe, como forma aparencial essencial, não só não tem nada que ver - em sentido negativo com nenhum irracionalismo, mas sim que tenta expressar - muito positivamente - um comportamento orientado à conquista da realidade objetiva, como toda autêntica ciência; mas, ao mesmo tempo, possui a possibilidade interna - e tem por consequência a tarefa - de descobrir novos aspectos, novos momentos da realidade que seriam inacessíveis ao espírito humano com outros meios. " $\mathrm{O}$ belo é - diz Goethe - uma manifestação de leis naturais ocultas que desconheceríamos eternamente se não fora por sua aparição fenomênica". 292
\end{abstract}

Esta articulação essencial entre mímesis e racionalidade, entre mímesis e conhecimento, entre arte e tecido histórico - aproximação realizada através de múltiplas mediações que não esgotam, mas reafirmam a profundidade contraditória da realidade fracassou em Miopia. A peça acabou por expor um processo de auto-dilaceramento de seus pressupostos, do seu material e do próprio modo de produção vivido por seus criadores.

Esse processo de autodilaceramento termina com uma forma que devora os seus próprios excrementos, para falarmos como Artaud: que constrói ao destruir. O labirinto em Miopia destrói o objetivo original de empreender a mímesis transparente do sistema capitalista tardio, das palavras do texto, do espaço que abrigou as cenas, dos objetos expostos na peça e dos conceitos investigados pelos autores.

Essa negação generalizada não constituiu qualquer processo de superação, o grupo não elaborou uma nova forma criada a partir da negatividade dialética: o labirinto é a exposição deste processo de confronto, que, como resultado, apresenta cenas em forma de excremento e de ruína do material teatral pesquisado.

${ }^{292}$ LUKÁCS, Gyorg. Estética, vol. 3. Barcelona- México D.F.: Grijalbo, 1967, p. 158. 
Excremento porque a desordem, o caos, a justaposição de alegorias em estado de enigma e o cadáver dos materiais utilizados permanecem perigosamente próximos do público, exigem que o espectador sinta o seu mau cheiro e manipule os seus restos, em busca de uma construção de sentido que parece ser sempre incompleta, porque construída a partir de derrotas.

Essas falhas e fracassos presentes no material labiríntico da peça poderiam ser lidos, em suas contradições, como a expressão de seu modelo secreto, uma nova realidade histórica, que encontraria dificuldades em ser expressa pelos paradigmas clássicos do drama e do teatro épico. No entanto, a faceta desta nova realidade histórica não é apresentada de maneira ordenada, mas encontra-se despedaçada, perdida em meio aos cadáveres de procedimentos e de alegorias acumulados por todo o percurso, à espera de decifração.

Esta paisagem arruinada, que denota presença da mímesis em Miopia, que se distingue da ideia de representação concernente aos teatros dramático, épico e pósdramático, está ligada ainda à persistência de materiais artísticos de épocas passadas, aproveitados como corpos mortos, em uma forma teatral que rememora a morte em todo o seu aspecto. Tal presença da morte é fundamental para a relação que o labirinto estabelece com o conceito de mímesis.

Theodor Adorno insiste num traço marcantemente sombrio que se impõe pouco a pouco à arte moderna, atingindo seu ponto culminante com Auschwitz: pela mortificação de seu caráter aparente, a mímesis intenta levar a cabo a incorporação crítica da crueldade intrínseca a seu feitio formal:

E, no entanto, a imagem do cadáver, a preparação da múmia, a execução elaborada de seu invólucro e a confecção da máscara mortuária estão certamente nas origens das manifestações artísticoculturais da espécie humana. A máscara mortuária sobretudo, cujo feitio poderia ser visto não só como forma prototípica das obras de arte, mas também alegórica. Não é tal qual máscara mortuária que aparece toda e qualquer forma de arte? ${ }^{293}$

Como toda imagem estética toma sua forma de algo que deixa de viver, a mímesis vem à luz moldando-se sobre algo que já não vive, e o que em imagem passa a viver acaba de morrer. Nas palavras da Teoria Estética, "sua vida alimenta-se da morte". Adorno ainda caracteriza como sendo o aspecto letal da obra de arte: “A afinidade de

\footnotetext{
${ }^{293}$ CHIARELLO, Maurício. Natureza-morta: finitude e negatividade em T.W. Adorno. São Paulo: Edusp,
} 2006, p. 158. 
toda beleza com a morte tem seu lugar na ideia da forma pura que a arte impõe à diversidade do ser vivo que nela se extingue".

A ambiguidade insolúvel própria de toda experiência estética, poderíamos ainda formulá-la do seguinte modo: distanciamento extremo, de morte, que no entanto encerra a promessa do contato mais vivo com a realidade. Contemplação do alto das montanhas, do lugar distanciado a partir do qual vem a reluzir bela e esperançosa a vida sem brilho e atormentada do dia-dia - quando todos os problemas e as dificuldades parecem suspensos, como que eternizados no passado. Mas a beleza que então se descortina, consumada na distância, perde as cores da vida erecobre-se de neve: inanimada, ela paga sua beleza com o preço da própria vida. ${ }^{294}$

Em visão semelhante à que vimos de Peter Weiss, presente na sua Estética da resistência, Adorno afirma que na qualidade de um representado, o feio, o cruel e o dissonante franqueiam a expressão do sofrimento na arte moderna. Tanto Weiss quanto Adorno redesenham a condição trágica da beleza notadamente após Auschwitz, apenas possível ao olhar que não se furta ao horrível e ao sombrio, sustentando dolorosamente a promessa utópica da reconciliação. "Todo negrume e toda culpa do mundo ela tomou sobre si. Toda sua felicidade consiste em reconhecer a infelicidade; toda sua beleza em subtrair-se à aparência do belo". Ou então: "As obras de arte procedem do mundo das coisas mediante seu material pré-formado e mediante seus procedimentos; nelas não há nada que ao mesmo tempo não pertença ao mundo das coisas e que não lhe haja sido arrancado a este ao preço de sua morte. Participam na reconciliação só graças a seu aspecto mortal". 295

No aforismo 78 de Minima Moralia, "Sobre as montanhas", Adorno toma o conto da Branca de Neve, na versão dos irmãos Grimm, como alegoria exemplar da melancolia inerente a toda imagem artística, esta imagem cuja beleza resplandece na morte e nela se mantém:

Sua imagem pura é a da rainha, que fita a neve pela janela e forma seu desejo da filha na beleza inanimada e viva dos flocos, no luto negro da moldura das janelas, no pungente sangramento; e depois morre no parto. Nem o final feliz atenua isso. Assim como a garantia se chama morte, a salvação não passa de aparência. (...) Assim nos fala uma voz quando esperamos salvação, que a esperança é vã e que, entretanto é apenas ela, a impotente, que de algum modo nos permite tomar ar. Toda contemplação nada mais permite senão retraçar com paciência a ambiguidade da tristeza em

\footnotetext{
${ }^{294}$ Idem, p. 159.

${ }^{295}$ ADORNO, Theodor. Teoria Estética. Madrid: Akal, 2004, p 181-182.
} 
suas sempre renovadas figuras e tentativas. ${ }^{296}$

Mas Adorno diz também de um outro modo: é somente graças a seu caráter letal, segundo o qual as obras causam a morte do que objetivam, que elas participam da reconciliação. Mediante a negação do vivo, elas possuem a capacidade de agir como uma espécie de antídoto mimético ao existente, sem o qual seria impotente o protesto da arte contra a opressão da civilização.

Que a arte esteja sempre nos deitar cinza nos olhos, gerando aparência de vida, é, paradoxalmente, o que lhe concede o condão de acordar o existente para as cinzas de tantos mortos, para as quais ele fecha deslumbrada e obstinadamente os olhos. Cinzas de um horror que seria bom manter dormente para sempre na memória - e este horror, como se adivinha, não é o horror da morte pura e simples, mas de algo muito pior que a morte: o infindável cinza de uma existência apagada, carente do brilho da plenitude: de uma existência de mortos-vivos impossibilitada de morrer deveras, definitivamente. ${ }^{297}$

Este aspecto letal da arte vai basear Hans-Thies Lehmann para traçar a sua ampla denominação de teatro pós-dramático. Mas, como vimos anteriormente, este caráter mortífero não está mais a favor da mímesis. O labirinto em Miopia representa aspectos da realidade do momento histórico presente, mas não através da totalidade "inefável" de contradições, de que nos fala Lukács e que pode ser aproximada do caráter mimético do teatro épico. Ao mesmo tempo, a morte da mímesis, preconizada por Lehmann em sua análise do teatro pós-dramático também não se ajusta para definir o labirinto.

Há em Miopia uma mímesis que se constrói através da morte, da morte do material escolhido para representar a realidade. Essa morte do material dá à peça, com a presença constante do lixo e do excremento, a capacidade de plasmar um momento histórico de crise permanente, em que a morte e a produção generalizada de destruição estão presentes como máscara mortuária do modo de devastação capitalista.

Ao contrário do modernismo, no entanto, teorizado por Adorno e ainda fortemente presente na estética de Weiss, o labirinto de Miopia dá outra configuração a esta face letal da arte já que não pode ser compreendido como uma "obra"; seu caráter de inconclusão e de movimento dão à peça a capacidade de traçar uma espécie de

\footnotetext{
${ }^{296}$ ADORNO, Theodor. Minima Moralia. Rio de Janeiro: Beco do Azougue, 2008, p. 118-119.

${ }^{297}$ CHIARELLO, Maurício. Op. cit., p.162.
} 
fisionomia do tempo presente: o rosto desenhado, no entanto, apresenta extrema dificuldade de leitura, talvez por sua feição de máscara mortuária em agonia.

\section{III}

A forma a que recorreu esta dissertação, o ensaio, procurou aderir ao seu objeto, tatear o labirinto sob diversos olhares, procurar suas entradas e saídas por todos os lados, chegando sempre a resultados inconclusivos. É assim contraditória qualquer tentativa de formular uma conclusão a este percurso crítico e talvez por isto este capítulo final esteja sendo redigido de maneira interrompida, sob a égide do fragmento e da pergunta, na busca imprecisa de revelar como inexistente qualquer organicidade da experiência estética presente em Miopia.

Como Ícaro, que em seu último olhar antes da queda pôde compreender a arquitetura do edifício estranho que o aprisionava, o labirinto de Miopia pode ser contemplado pela última vez nesta dissertação na cena seguinte, em que a imagem do espaço barrado, com suas entranhas inomináveis, também surge como configuração da ausência de saída:

\section{MARIBEL E O ELIXIR DA VIDA}

JOHANSEN - (enquanto conduz o público) Fujam! Fujam de mim! Porque ninguém deve permanecer nas ruas por onde passa um amaldiçoado, um leproso, um gado sem marca: a desgraça pega de longe e até vê-la é perigoso. Mas para quem quiser, eu conheço a putrefação. Eu posso provar. Venham comigo. Vejam. A filha da arquiteta. Ela vai se vender. Maribel entra brigando com a própria sombra. Na vitrine um espelho. Letreiro: CRIE O AUTÔMATO DE UMA ESTRELA DO CINEMA COM O SEU ROSTO.

\section{(...)}

Maribel e Belmiro caminham a um porão. Antes de entrar, Belmiro ajoelha e reza, para um cadáver.

BELMIRO - Quando eu te der a vida

Teus olhos piscarão para além de toda maquinaria, cheios de alma. Quando eu te der a vida

$\mathrm{O}$ teu corpo pulsará cada ritmo imprevisto, da raiva à calma

Quando eu te der a vida

A minha loucura, minhas horas de insônia e tristeza

Serão glória, sabedoria e riqueza

Quando eu te der a vida

Todos terão, em todos os mercados e esquinas,

A vida a seu dispor, em embalagens vedadas e milimetricamente produzidas 
Vendidas

Como um poema que a Natureza assina

Por que o corpo é uma embalagem que só existe

Para proteger a vida de toda ferida triste.

As luzes se acendem. Em cada divisória, suspensos com cordas no pescoço, há um boneco. No centro, um espelho.

MARIBEL - O cheiro é insuportável.

BELMIRO - São corpos sem vida. Eu já me acostumei. (segura Maribel, que tenta vomitar) Calma, olhe para cada um deles, esperando a vida, que você melhora. Maribel melhora.

MARIBEL - Você dorme no meio da morte.

BELMIRO - Eu durmo sonhando com a vida! São experimentos. Ainda vou criar a vida totalmente a partir de matéria orgânica morta. De cadáveres.

MARIBEL - Eles não têm rosto.(olha para o espelho)

BELMIRO - Mas vão ter. Veja: qualquer um pode fazer. Liga o chuveiro. O material sobre as faces brancas dos bonecos derrete. É ácido. Coloque aquelas luvas. Maribel coloca as luvas. Coloque as duas mãos sobre a face, é matéria orgânica pura. Parece massa de modelar.

MARIBEL - É um cadáver.

BELMIRO - Deixe a sua sensibilidade te levar. Manifeste o que há de mais íntimo em você.

MARIBEL - Eu não tenho nada dentro de mim.

BELMIRO - Claro que tem. Tudo mundo tem! Qualquer um que tocar o sem rosto destes corpos pode lhes dar feições, imagens. Deixe as suas mãos trabalharem sozinhas!

MARIBEL - (depois de ter manipulado o rosto do boneco) É quase um rosto bonito.

BELMIRO - Continue, continue! Deixe a sua alma de artista te conduzir, o seu inconsciente criador! (...) Desenhe o seu próprio rosto.

MARIBEL - Eu não consigo. (tenta de novo) É o rosto do comercial da folha de sulfite. (tenta de novo) Não é o meu rosto. Eu não conheço este rosto. (tenta de novo) É de novo o rosto da propaganda de charutos! Eu não consigo!!!

BELMIRO - Você não consegue fazer o seu próprio rosto. É normal. Eu posso salvar a sua imagem para você. $\mathrm{Eu}$ faço o autômato de Zuzu com o rosto de Maribel. É só você querer.

MARIBEL - Quanto custa?

BELMIRO - É questão de afeto e não de preço. Ou do preço do afeto. Belmiro liga o chuveiro.

MARIBEL - Quanto custa? Quanto custa? Quanto custa. Maribel entra no chuveiro. ${ }^{298}$

${ }^{298}$ ALMEIDA, Ligia Marina, DELMANTO, Ivan, FARIA, Fernanda, et al. Miopia. Inédito, 2006, p. 34. 
As entranhas do labirinto surgiam quando o público, na cena de número 21 da peça, após ter percorrido circularmente o espaço amplo fora da Usina, em busca de entrada, além de todo o primeiro andar, era conduzido a um vestiário abandonado, estreito, comprido e de teto baixo, onde se entrava por uma porta ainda mais estreita. $\mathrm{O}$ vestiário era antítese de toda a amplidão percorrida nas demais cenas e espaços de Miopia, espécie de pausa ou paralisia da peça. Johansen, que narra esta cena, como um rato era o único capaz de adentrar um ambiente tão fétido e apodrecido e por isso o público era cuidadosamente conduzido por ele. A cena realizada no vestiário - sujo e abandonado e que tinha a aparência deteriorada ressaltada pelos pedaços de corpos (confeccionados com isopor) espalhados - pode ser vista, mesmo com o seu caráter de apêndice à narrativa e talvez por isso mesmo (a cena chegou a ser cortada em algumas apresentações da peça, exatamente por configurar um desvio desnecessário à história da cidade) como espécie de planetário em que as características do labirinto podem ser identificadas.

A presença da morte, multiplicada agora, surge na cena 21 de Miopia inicialmente no plano da ação: Belmiro agora cria seus autômatos a partir da manipulação de cadáveres. Estes cadáveres foram confeccionados por uma escola de samba que ocupava durante o carnaval o estacionamento da Usina. Marcos, o ator que interpretava Belmiro, recolheu do lixo da escola diversos pedaços de boneco, troncos, braços, pernas, cabeças, todas feitas de isopor, e este lixo recuperado formou quase todo o cenário da cena. $\mathrm{O}$ acúmulo destes pedaços de corpos, em um espaço estreito, escuro e mal-cheiroso, dava à cena esta presença constante de algo morto. O método de construção da cena aqui representa bem o processo de criação da peça em que antigos materiais e procedimentos artísticos foram recuperados e expostos em sua morte, sem nenhuma tentativa de ressurreição. A ideia de labirinto aqui envolve o acúmulo de elementos, o amontoado de ruínas, o empilhamento de signos, o que é bem representado pelos pedaços das antigas atrações da escola de samba, empilhados no estreito espaço do vestiário.

Inicialmente, a presença dos corpos de isopor na encenação estaria em relação direta com o sentido narrativo proposto pelo texto. Este sentido esteve presente na cena. Contudo, a maneira como os pedaços de boneco estavam dispostos na cena era capaz de acumular ao sentido inicial do texto, outros tantos signos materiais, dando ao resultado final um caráter caótico de difícil leitura, por vezes confundindo a compreensão da situação cênica proposta. Com bonecos aos pedaços espalhados pelo chão, o público 
via-se obrigado a transitar e sentar em meio a este espaço exíguo. As paredes e o chão do vestiário, cobertas por azulejos vermelhos, contribuíam para a escuridão e para ecoar as palavras ditas na cena, embaralhando as imagens e os sons. Alguns destes bonecos, os mais inteiros, estavam pendurados abaixo dos chuveiros por fios de nylon presos ao teto. O exercício que Belmiro propõe a Maribel, fazer do rosto dos cadáveres o seu próprio rosto, era realizado aqui: ligava-se o chuveiro e, com a água caindo sobre os bonecos, Maribel tentava, sem conseguir, moldar o próprio rosto. A água que caía sobre os bonecos enquanto Maribel manipulava seus rostos, que assumiam, a cada instante, uma nova face, parece alegorizar a própria presença das alegorias na peça: a imagem do cadáver capaz de assumir várias faces, sem nunca atingir a almejada, pode ser vista como imagem das alegorias presentes no labirinto.

Por fim, a cena terminava com os vários chuveiros ligados, no barulho contínuo da água que escorria e com a pergunta repetida de Maribel: "quanto custa? Quanto custa?" Os dois personagens debaixo da água assim permaneciam por alguns minutos, enquanto a pergunta ecoava pelo vestiário. Em meio aos bonecos e a água a pergunta parecia referir-se também a Maribel e a Belmiro e à própria peça como um todo. A ausência de resposta, a uma pergunta repetidamente formulada, também é uma ação da cena que pode representar característica do labirinto em Miopia.

\section{IV}

Esse feixe de procedimentos de construção e recursos de linguagem reforça a ambiguidade do labirinto, na medida em que introduz a hesitação, a dúvida, no nível da composição das dramaturgias da peça, ampliando os horizontes da significação e envolvendo cada vez mais o espectador no processo de criação de sua dramaturgia própria. Estas dramaturgias, paradoxalmente, são incapazes de guiar o observador rumo a uma saída e são formadas, com efeito, por fatores de abertura, na acepção que dá ao termo Umberto Eco. ${ }^{299}$ Os fatores de abertura multiplicam as perspectivas de compreensão de Miopia, tornando-a uma rede inesgotável de relações e de percursos.

Ao mesmo tempo, porém, todos esses recursos assinalados, em maior ou menor grau, são elementos de desordem, rupturas e bueiros que atraem para o caos, ameaçando

${ }^{299}$ ECO, Umberto. A obra aberta. São Paulo: Perspectiva, 1996, p. 7. 
esfacelar a obra, enquanto sistema acabado de signos. Aumentar a ambiguidade, aumentando, consequentemente, a informação estética tem como limite extremo a desintegração da obra no caos.

Eco refere-se a uma necessária dialética entre forma e abertura: segundo esta concepção, o artista pode introduzir a desordem suficiente para um certo grau de abertura, mas não ultrapassar os limites de uma mínima organização, sem o que já não existiria a obra: "Entre a sugestão de uma pluralidade de mundos formais e o caos indiferenciado, que suprimiria toda possibilidade de fruição estética, não há senão um passo: para o compositor de uma obra aberta, a solução se acha numa dialética pendular." 300

Esta atração aparentemente irresistível de desintegração da obra, atração suicida ao caos, é o caráter de crise do labirinto.

O itinerário labiríntico que o ensaio em devir de Miopia descreve representou uma tentativa reiterada de se ir adiante dos limites da linguagem, em busca do que se pressentia como indizível. Entretanto, ao aumento da desautomatização da linguagem, da destruição de fórmulas estereotipadas, corresponde um aumento da ambiguidade, da abertura ao leque de possibilidades interpretativas do experimento teatral.

No labirinto de Miopia, a mensagem completamente ambígua se avizinha do ruído, tendendo, portanto, a reduzir-se à desordem total. A busca da sobreposição de diversos sentidos, em uma montagem ou tessitura de dramaturgias, aproxima cada cena do caos, anulando, paradoxalmente, a experiência que é, no conceito de Norbert Wierner, a medida de uma ordem, mesmo que totalmente nova. A busca da abertura máxima de sentidos conduz, assim, à destruição completa da obra de uma unidade orgânica de sentido, deixando ao espectador, como resto desta demolição, o labirinto, em crise de sentido permanente.

Esta dialética pendular entre os múltiplos sentidos e o vazio absoluto, de que nos fala Eco, constituiu também o processo de criação da peça a partir da experimentação sobre o conceito de dramaturgias. A prática a partir das diversas relações entre as dramaturgias se traduziu num aglomerado de imagens, provenientes das diversas linguagens, que puderam se coagular numa tentativa de revelação da realidade, isto é, o conceito de dramaturgias envolveu uma recuperação da montagem de imagens alegóricas como procedimento instaurador da realidade poética do labirinto.

${ }^{300}$ ECO, Umberto. Op. cit., p.10. 
Como observa Arnold Hauser, a montagem põe em relevo "não só a natureza mista da realidade, os diversos graus de realidade nos quais se desenvolve a existência humana em seus diferentes aspectos, não apenas o caráter contraditório do ser, mas também o caráter de jogo que distingue todo estilo".

A espécie de montagem formadora do labirinto, por outro lado, foi uma solução construtiva e destrutiva ao mesmo tempo: construtiva uma vez que a montagem de dramaturgias pôde estabelecer relações estruturadoras entre os elementos em jogo, resultantes da destruição da hierarquia entre os elementos teatrais; destrutiva uma vez que tal montagem acumulou signos sem hierarquia, tensionando os sentidos presentes na dramaturgia textual ao seu limite, gerando ao espectador um percurso constante de idas e vindas na busca por novas possibilidades de construção de significados, desequilibrado o tempo todo sobre o vazio.

A montagem, um dos mais eloquentes modos de articulação na produção de sentido das obras do modernismo, em Miopia desorganizado e desestruturado sob a forma do labirinto, é também o modo como a peça explicitou a sua impotência diante da tarefa de representação do capitalismo; a negação da síntese tornou-se princípio de configuração; seus resíduos deram sentidos vários às cicatrizes visíveis. O labirinto em Miopia denunciaria e renegaria a aparência de organicidade da experiência.

Esta renúncia à unidade como princípio formal ainda permaneceria como unidade, labiríntica, no entanto. Assim, após todo processo de estudo que gerou a peça e foi ao mesmo tempo negado por ela, o procedimento épico mais presente na peça, ainda que mantido como cadáver já que presente como gerador de caos e não de unidade de sentido, é o da montagem, recuperado e morto em Miopia sob a forma de montagem de dramaturgias.

No ensaio "Montagem", de 1938, Eisenstein, que tem uma concepção estrutural da obra de arte como uma totalidade, como uma construção unitária em que os elementos componentes se interligam coesamente, assinala duas características fundamentais do princípio formal de montagem. Em primeiro lugar, a montagem não é apenas um conjunto adicional de elementos, mas um todo em que a justaposição das partes "se assemelha mais ao produto que à soma". Assemelha-se ao produto, e não à soma, porque o resultado da justaposição difere sempre qualitativamente de cada um de seus elementos componentes, tomados em separado. Ou ainda:

os elementos não existem mais como qualquer coisa independente, mas como uma representação particular de um único tema de 
conjunto que os atravessa a todos igualmente. A justaposição desses detalhes particulares em certo modo de montagem chama à vida, torna perceptível, o conjunto que imaginou cada parte, ela as liga umas às outras num todo, nessa imagem sintética onde o autor e, depois dele, o espectador experimentarão o tema em questão. ${ }^{301}$

Em segundo lugar, como consequência, a montagem exige uma participação ativa do espectador:

\begin{abstract}
A imagem inventada pelo autor torna-se a própria substância da imagem do espectador... Fabricada por mim, espectador, nascida, surgida em mim. Não somente obra do autor, mas obra minha como espectador, espectador que é também um criador. ${ }^{302}$
\end{abstract}

Esta concepção de montagem labiríntica de dramaturgias exigiria assim a transformação do espectador de consumidor a consumidor da obra.

O crítico de arte David Sylvester, em ensaio sobre a pintura tardia de Paul Klee, observa que seus quadros caracterizam-se por uma aglomeração de signos que não possui início ou fim, já que parece poder ir além dos limites da tela ou do papel, e não possui um eixo, um ponto focal em que o olho pudesse repousar para ver o quadro, situando-se em torno deste ponto, como um todo ordenado.

Deparando-se com um labirinto incoerente ou às vezes com uma confusa dança de cores, o espectador tenta compreender o quadro fixando o olhar num ponto focal para onde todos os signos estejam orientados. No entanto, encontra, como diria Gertrude Stein: “ uma composição que não tinha nem início nem fim, na qual um canto era tão importante quanto outro". Na pintura tardia de Klee, cada ponto é tão crucial quanto qualquer outro e nunca há um ponto no qual o olho do espectador possa finalmente repousar. Segundo Sylvester:

Logo o espectador descobre que esse movimento do olho de signo para signo o puxa, em imaginação, para dentro do quadro. Ele se rende à essa atração magnética, entra em algum ponto do quadro e começa a percorrê-lo. É então que a pintura começa a se tornar legível e articulada. Ele encontra um signo e pára, move-se ao longo dele e descobre que ele lhe indica a direção a tomar em seguida, o próximo signo a ser encontrado. E assim segue o seu caminho, frequentemente retornando a um signo que já visitou para descobrir que este agora significa algo diferente do que significava quando fora abordado numa outra direção ${ }^{303}$.

\footnotetext{
${ }^{301}$ EISENSTEIN, Sergei. "Palavra e imagem (Montazh 1938)". In: O sentido do filme. Rio de Janeiro: Jorge Zahar, 2002, p. 34.

302 Idem, ibd.

${ }^{303}$ SYLVESTER, David. Sobre arte moderna. São Paulo: Cia. das Letras, 2005, p.190.
} 
Este circular do espectador pelo quadro é a primeira ação do espectador no labirinto: habitar a obra, como o passeio de Lenz pelas montanhas (relatado por Büchner), experimentando o espaço de aventura que esta propõe:

O passeio do esquizofrênico: eis um modelo melhor do que o neurótico deitado no divã. Um pouco de ar livre, uma relação com o fora. Por exemplo, o passeio de Lenz reconstituído por Büchner. É diferente dos momentos em que Lenz se encontra na casa do seu bom pastor, que o força a se ajustar socialmente em relação ao Deus da religião, em relação ao pai, à mãe. No seu passeio, ao contrário, ele está nas montanhas, sob a neve, com outros deuses ou sem deus nenhum, sem família, sem pai nem mãe, com a natureza. ${ }^{304}$

Além de espacial, para Paul Klee a atividade do espectador é também temporal:

a atividade do espectador é essencialmente temporal. Ele assimila parte após parte em seu campo de visão, e para poder se sintonizar com uma nova parte precisa deixar a precedente. ${ }^{305}$

O acúmulo e a justaposição de uma multiplicidade de visões de uma obra artística representam as percepções deste espectador esquizofrênico em diferentes etapas de um passeio que habita o labirinto, modificando a sua noção cotidiana de espaço e de tempo. O "espectador esquizofrênico", habitante de Miopia, depara-se com alegorias sucessivamente em sua jornada que, não sendo mais limitada por sua moldura original, é como um caminho, que muda em estrutura à medida que o espectador o percorre no tempo, em que o espaço é criado pelo movimento do espectador e cujo espectador é sempre o ponto focal.

O labirinto torna-se assim perpétuo devir e o seu público precisa projetar-se para dentro deste fluxo, pois a tentativa de interpretá-lo consiste em habitar tal devir, de saídas constantemente barradas. A montagem, que através da violenta e abrupta justaposição visava, nas obras modernistas, fazer gritar o sentido de uma realidade aparentemente incompreensível, em Miopia torna-se assim pêndulo entre a capacidade de expressão e o emudecimento.

\footnotetext{
${ }^{304}$ DELEUZE, Gilles, GUATTARI, Felix. O Anti-Édipo. São Paulo: Ed. 34, 2010, p. 12.

${ }^{305}$ SYLVESTER, David. Op. Cit., p. 191.
} 
Já explicitamos acima o caráter de crise do labirinto. O labirinto coloca em crise os procedimentos teatrais épicos e dramáticos, dissolvendo-os em um movimento esquizofrênico da forma e do conteúdo que vai da multiplicidade de sentido ao vazio absoluto. Caracterizar o labirinto Miopia como presença constante da crise pode nos levar, depois de percorrermos, como mediação, alguns dos procedimentos formais presentes na peça sem, no entanto, esgotá-los, a uma alegoria do momento presente estabelecido também como crise contínua.

Um dos possíveis diagnósticos desta crise, apresentado por Robert Kurz no seu ensaio $A$ crise do valor de troca ${ }^{306}$, estabelece - em linhas gerais - que o capital, através do aumento compulsivo da produtividade (ou da força produtiva) induzido pela concorrência de mercado, cava a sua própria sepultura, porque retira cada vez mais do processo de produção criador de mais-valia o trabalho, e com ele a sua própria substância. Neste contexto desempenha um papel especial a "força produtiva ciência" em geral e a "revolução microeletrônica" em particular. O texto pode ser lido como uma elaboração e atualização de uma célebre constatação de Marx, contida no já citado fragmento sobre as máquinas: “o capital é, ele próprio, a contradição em processo porque procura reduzir o tempo de trabalho a um mínimo, enquanto, por outro lado, estabelece o tempo de trabalho como única medida e fonte da riqueza".

Miopia expressaria, no material de seu labirinto, este beco sem saída desta etapa de produção permanente de crise, essencial ao estágio atual de produção de valor. Seria, do ângulo doutrinário, a vitória definitiva do mercado e de seus mecanismos; do ângulo histórico, pelo contrário, tratar-se-ia da inviabilização de imensos esforços de integração à modernidade, postos fora de combate pelos rigores da concorrência global, ou seja, pela própria lógica do sistema de produção de mercadorias, que passou à autodestruição. Impossíveis de generalizar, os avanços daquele padrão começam a ser inalcançáveis, a passar da conta para os próprios países ricos, onde o desemprego ligado à nova rentabilidade vai criando manchas terceiro-mundistas. Segundo Roberto Schwarz:

A modernização - termo que designa a utilização empresarial de trabalho abstrato - toca o seu limite e entra em colapso quando prospera até o ponto de perder a capacidade de ser uma perspectiva praticável para fatias crescentes da atividade econômica mundial

${ }^{306}$ KURZ, Robert. La crise del valor de cambio. Mexico D.F.: Critica Marxista, 1986, p. 7-48 
derrubadas e expulsas pela competição, a que não têm como voltar. Ao contrário do que a ideologia afirma, o mercado não é a solução, mas o problema. ${ }^{307}$

Diferentemente da epopeia de Marx, retratada pelo teatro épico e que saudava a abertura de um ciclo, Miopia e o labirinto são inspirados pelo seu presumido encerramento. Se em Marx assistimos ao aprofundamento da luta de classes onde as sucessivas derrotas do jovem proletariado são outros tantos anúncios de seu reerguimento mais consciente e colossal, em Miopia, mais de 150 anos depois, o antagonismo de classe perdeu a virtualidade da solução, e com ela a substância heroica. A dinâmica e a unidade são ditadas pela mercadoria fetichizada - o anti-herói absoluto - cujo processo infernal escapa ao entendimento de burguesia e proletariado, que enquanto tais não o enfrentam.

Segundo Schwarz, postas em xeque pelo novo patamar das forças produtivas, as nações que se haviam lançado à industrialização tardia perdem as condições de coesão e tornam-se sociedades pós-catastróficas, nas quais o desmantelamento já ocorreu e a normalidade é um verniz. Com o projeto de modernização, no que ele tinha de substantivo, ou seja, no que dizia respeito a todos, ficou para trás.

Para estes países, a reprodução coerente no espaço da concorrência global deixou de ser um horizonte efetivo, e predomina a tendência à desagregação. Noutras palavras, a generalização do salariato e da cidadania está mais distante. Assim, o desenvolvimentismo liberou e arrancou as populações de seu enquadramento antigo, para as reenquadrar num esforço de industrialização nacional, que a certa altura, impossibilitado de prosseguir competindo, as abandona sem terem para onde voltar, na qualidade de sujeitos monetários sem dinheiro, ou de ex-proletários virtuais, agora disponíveis para a criminalidade e os fanatismos nacionalistas ou religiosos. ${ }^{308}$

Estes sujeitos monetários sem dinheiro são os personagens do labirinto. Ao colocar em foco essas complementaridades calamitosas que do ângulo da reflexão liberal exemplificam o atraso merecido dos que não assimilaram os mecanismos de mercado, podemos observar o avesso do avanço contemporâneo, talvez o grande tema que configura o labirinto de Miopia.

E se o aspecto da modernização que nos coube, assim como a

\footnotetext{
${ }^{307}$ SCHWARZ, Roberto. “Ainda sobre o livro de Kurz”. In: Novos estudos, edição 37. CEBRAP: novembro de 1993. Versão eletrônica: http://novosestudos.uol.com.br/indice/indice.asp?idEdicao=71\#579. Consultado em 12/1/2011.

${ }^{308}$ Idem, ibd.
} 
outros, for o desmanche ora em curso, fora e dentro de nós? E quem seríamos nós neste processo? ${ }^{309}$

Este desmanche generalizado está presente nas ruínas que formam e deformam o labirinto, construção que utilizou prioritariamente o lixo como material. $\mathrm{Na}$ cena analisada acima, a do encontro entre Belmitro e Maribel, o diálogo surge em desmanche: os personagens já não podem comunicar-se a não ser mediados pelo cadáver. A narrativa surge em desmanche: não há conclusão e desenlace ao conflito instaurado. O próprio sentido está já desmanchado pelos detritos acumulados no espaço cênico pela encenação, que desviam e deslocam o espectador todo o tempo de qualquer lugar interpretativo seguro.

\section{VI}

A conduta por vezes utilizada neste trabalho, a de promover a fricção entre textos literários diversos e a análise da peça (Samuel Beckett, Bruno Schulz, Jorge Luis Borges) justifica-se se pensarmos que o próprio labirinto surgiu também do alarido gerado pelas inúmeras vozes, de procedências múltiplas, que configuraram o texto e a construção dos personagens e da encenação. Também é possível identificar na expressão literária verdadeiras "imagens dialéticas", traços que podem nos aproximar das molduras pelas quais pretendemos ler Miopia. Para tanto, podemos terminar esta conclusão à maneira circular de Miopia, aproximando-nos novamente do romance de Peter Weiss, mencionado na introdução deste trabalho.

Em 1819, A balsa de medusa, quadro de Théodore Géricault havia entrado na Academia, constituindo-se em um perigoso ataque contra a sociedade estabelecida. Não só por suas enormes dimensões $(4,91 \times$ x 7,16 m), mas também porque expunha a corrupção do Estado francês. Os antecedentes do quadro eram um fato real. Em dois de julho de 1816, o Medusa, navio de bandeira francesa, fora a pique nas proximidades de Cabo Blanco por causa da incompetência do comandante e da negligência das autoridades da marinha. Os botes de salvamento apenas podiam acolher à metade dos cerca de trezentos colonos e soldados a bordo. O capitão, os altos oficiais e os passageiros mais influentes ocuparam os botes à força. $\mathrm{O}$ restante dos náufragos fora

\footnotetext{
${ }^{309}$ Idem, ibd.
} 
abandonado a sua própria sorte, em uma balsa construída com tábuas e pedaços do mastro. Das cento e cinquenta pessoas da balsa, depois de duas semanas só quinze permaneceram com vida. Os representantes da Restauração viram no quadro exposto no Salão de Outono um primeiro passo para uma revolta contra o regime e procuraram esconder a obra em um lugar obscuro do Salão. A catástrofe do Medusa havia se convertido no símbolo de um estado existencial:

Cheios de desprezo, dando de ombros aos que fugiram nos botes, formavam os que iam à deriva, os náufragos na balsa representavam a uma geração abandonada que em sua juventude todavia havia conhecido a tomada da Bastilha. Apoiavam-se entre si, todos os conflitos que lhes haviam levado a embarcar já haviam passado, se havia esquecido a luta, a fome, a sede, a morte em alto mar, entre eles havia aparecido uma unidade, apoiando-se uns em outros, juntos se afundariam ou juntos se salvariam, e o fato de que o que agitava o trapo, o mais forte deles, fosse um africano, que talvez tivesse embarcado no Medusa para ser vendido como escravo, fazia pensar na liberação de todos os oprimidos ${ }^{310}$.

O quadro, cuja composição seguia o princípio da diagonal dupla, deslocava também as perspectivas. No triângulo imaginário da esquerda se aglutinavam os náufragos, agonizantes de esgotamento e de dor. $\mathrm{Na}$ direita alguns sobreviventes agitam um trapo com a esperança de que o navio Argus, cuja silhueta se vislumbra no horizonte, pudesse resgatá-los. Mas na balsa parece desvanecer-se toda esperança e o centro da pintura está ocupado pelos náufragos entre a dor, a resignação, a raiva e a espera.

Esta espera por uma revolução social que já não se vislumbra no horizonte é uma das molduras que circunscrevem as alegorias acumuladas nas ruínas do labirinto de Miopia. Este labirinto alegoriza uma "geração abandonada", um momento histórico em que se encontram arruinados os materiais capazes de expressar "a luta, a fome, a sede, a morte em alto mar", restando a espera ou a reconstrução de novas formas, a partir de uma aparente liberdade de escolha de material que, em si mesma, é limitação extrema.

Entre a espera e a reconstrução, os autores de Miopia optaram pela reconstrução. Naufragaram. Desta derrota, emergiu o labirinto, que entre esperar e reconstruir realizou a destruição. Do que restou, escrevemos esta dissertação, tentando fixar questões, à maneira de quem agita um trapo em um bote à deriva.

Davi Arrigucci termina assim seu livro sobre Júlio Cortázar:

A crítica é um enorme e provavelmente vão esforço para

${ }^{310}$ WEISS, Peter La estética de la resistência, op. cit., p. 391. 
reconquistar a unidade da obra, perdida desde o instante em que começa a destruição pela análise. A seu modo, também a interpretação, desejo extremo da visão global, nasce dos escombros, da visão fragmentária, dos saltos, que por mais longe que vão, sempre ficam aquém do que se busca, esse algo que sempre fica enrodilhado, sabe lá em que dobras da realidade múltipla de sentido, bote armado, à espreita do assaltante. ${ }^{311}$

O labirinto Miopia forneceu a seus espectadores - e agora à tarefa da crítica - este desafio de combinar busca por unidade e dissecação promovida pelo pensar analítico. $\mathrm{O}$ resultado atingido, porém, pela leitura da peça, nascido dos escombros, permanece como detrito, incapaz de reunir estes estilhaços em uma interpretação totalizante.

A constelação de aspectos tratados para dar forma ao labirinto da peça é incapaz de fornecer orientação para além de seu aspecto de crise no próprio firmamento. Miopia é resto e rastro deste planetário teatral em derrocada, em que a busca por novas formas artísticas tem que se haver com conteúdos sedimentados por um mundo em crise permanente.

${ }^{311}$ ARRIGUCCI Jr., Davi. O escorpião encalacrado. São Paulo: Cia. das Letras, 1995, p. 305. 


\section{ANEXO}

FICHA TÉCNICA DE MIOPIA

\section{Criação:}

II Trupe de Choque

\section{Direção e Dramaturgia:}

Ivan Delmanto

\section{Elenco:}

Elenira Peixoto

Estefânia Lopes

Fernanada Faria

Juliana Liegel

Lígia Marina

Marko Concá

Marcus Lima

Silvana Ramos

Estagiários de atuação:

Daniel Mártire

Thiago Almeida

\section{Direção técnica:}

Margarida Ares

Desenho de luz:

André Moncaio

Elizeu Kouyaté 
Direção Musical e Preparação Vocal:

Marko Concá

\section{Cenografia:}

Margarida Ares

Virgílio Gonçalves da Costa

\section{Figurinos:}

Tatiana Haumhlter

\section{Cenotecnia e contrarregragem:}

Margarida Ares

Virgílio Gonçalves da Costa

Cardeal de Miranda

Tiago Claus

Mateus Fiorentino Nanci

Confecção de bonecos:

Eduardo G. de Aguiar

Assistente confecção de bonecos:

Léia Izumi

Programação visual:

Cláudio Queiroz

Direção de Produção:

Marcus Lima

Produtora - assistente: 
Fabiana Saraiva Costa

Assessoria técnica de luz:

$\mathrm{PH}$

Wagner Costa

Djalma das OLiveiras

Sebastião Otávio (Tião)

Iluminador assistente:

Sebastião Otávio (Tião)

Operação de luz:

Sebastião Otávio (Tião)

Djalma das Oliveiras

Estagiários de iluminação:

Cristiano Souza da Silva

Elizeu Kouyaté

Érica da Silva

Fábio dos Santos

Gabriel Greghi

Joyce Ribeiro

Priscila Santos

Grafitagem:

NEG

Edição de som:

Estevão Romane

\section{Costureira:}


Zelita Ribeiro

Cozinha e limpeza:

Margarida Ares

\section{Seguranças:}

José Maria

Edson

Máscara de ferro:

Roni

Máscara Neutra Maribel:

Léia Azumi

Roteiro, direção e edição de video:

André Moncaio

Fotografia e camera:

André Moncaio

Câmera adicional:

Wagner Klebson

Fábio dos Santos (Careca)

Som:

André Moncaio

Wagner Klebson

Operador de projeção: 
Elizeu Kouyaté

Documentarista:

André Moncaio

Assessoria de imprensa:

Ligia Marina

Marcus Lima 


\section{REFERÊNCIAS}

ADORNO, Theodor W. and Walter Benjamin (1999) The Complete Correspondence 1928-1940, trans. Nicholas Walker, Cambridge: Harvard University Press.

ADORNO, Theodor. "Mahagonny”. In: Escritos musicales IV. Madrid: Akal, 2004. . Crítica de la cultura y sociedad I. Madrid: Akal, 2006. . Filosofia da Nova Música. São Paulo: Perspectiva, 2009. . Minima Moralia. Rio de Janeiro: Beco do Azougue, 2008. . Monografias Musicales. Madri: Ediciones Akal, 2008. . Notas sobre literatura. Madrid: Akal, 2003. . Teoria estética. Madrid: Akal, 2004.

ALIGHIERI, Dante. A divina comédia:Inferno. São Paulo: Ed. 34, 1998.

ALMEIDA, Jorge. Crítica dialética em Theodor Adorno. Cotia, São Paulo: Ateliê Editorial, 2007.

ALMEIDA, Ligia Marina, DELMANTO, Ivan, FARIA, Fernanda, et al. Miopia. Inédito, 2006. - Anjos do Desespero. Projeto de pesquisa teatral. Contemplado pela V Edição da Lei de Fomento ao Teatro do Município de São Paulo. Inédito, 2005. Disponível para consulta na Divisão de Fomento da Secretaria Municipal de Cultura. . Anjos do Desespero. Relatório da primeira etapa de pesquisa. Apresentado à Secretaria de Cultura do Município de São Paulo. Inédito, 2005. Disponível para consulta na Divisão de Fomento da Secretaria Municipal de Cultura. . Anjos do Desespero. Relatório da terceira etapa de pesquisa. Apresentado à Secretaria de Cultura do Município de São Paulo. Inédito, 2006. Disponível para consulta na Divisão de Fomento da Secretaria Municipal de Cultura. Miopia - Programa do espetáculo. Inédito, 2006.

ANDRADE, Daniel Pereira. Dispositivo de controle emocional. Poder e emoções na economia contemporânea. 2009. Exame de qualificação de doutorado apresentado ao Departamento de Sociologia da Faculdade de Filosofia, Letras e Ciências Humanas da Universidade de São Paulo.

ANDRADE, Fabio de Souza. Samuel Beckett: o silêncio possível. Cotia: Ateliê Editorial, 2001. 
ARANTES, Paulo Eduardo. Sentimento da Dialética. São Paulo: Paz e Terra, 1992. ARISTÓTELES. Poética. In: Os Pensadores. São Paulo: Abril Cultural, 1977.

ARRIGUCCI Jr., Davi. O escorpião encalacrado. São Paulo: Cia. das Letras, 1995.

ARTAUD, Antonin. Cartas desde Rodez. Madrid: Fundamentos, 1984. . Heliogabalo ou o Anarquista Coroado, Assírio e Alvim, 1982. . Works from the final period. Boston: Exact Change, 1995.

ASMAN, Carrie L. 'Theatre and Agon/Agon and Theatre: Walter Benjamin and Florens Christian Rang,' In: Modern Language Notes 107, Cambridge: Harvard University Press, 1992.

BACON, Francis. Ensaios. Lisboa: Guimarães Editores, 1992.

BARBA, E.; SAVARESE, N. A arte secreta do ator: dicionário de antropologia teatral. São Paulo, Campinas: Hucitec, 1995.

BARBA, Eugênio. Queimar a casa: origens de um diretor. São Paulo: Perspectiva, 2010 .

BASBAUM, Leôncio. História Sincera da República. São Paulo: Difel, 1978.

BAUDELAIRE, Charles. Obra completa. Rio de Janeiro: Aguilar, 1997.

BAUDRILLARD, Jean. Simulacros e simulação. Lisboa: Relógio d'água, s/d.

BAUMAN, Zygmunt. Vidas desperdiçadas. Rio de Janeiro: Zahar, 2005.

BECKETT, Samuel. Como é. São Paulo: Iluminuras, 2003.

BENJAMIN, Walter. Obras Escolhidas III. São Paulo: Brasiliense, 1989. . As Passagens. Belo Horizonte: Ed. UFMG; São Paulo: Imprensa Oficial do Estado de São Paulo, 2006. . Origem do drama trágico alemão. Lisboa: Assírio \& Alvim, 2004. . Selected writings, vol.1 . London: Belknap Harvard, 2002. . The correspondance of Walter Benjamin, 1910-1940. Chicago: Chicago University, 1994.

BOLTANSKI, Luc e CHIAPELLO, Ève. O novo espírito do capitalismo. Martins Fontes: São Paulo, 2009.

BONFITTO, Matteo. Tecendo sentidos. Inédito, 2008.

BORGES, Jorge Luis. "Os animais dos espelhos". In: O Livro dos seres imaginários. São Paulo: Cia. das Letras, 2008.

BRECHT, Bertolt. A compra do latão. Lisboa: Vega, 1999. 
. Escritos sobre teatro, vol.2. Buenos Aires: Nueva Visión, 1975.

. Escritos sobre teatro, vol.1. Buenos Aires: Ediciones Nueva vision, 1973.

. Narrativa completa, 3. Madrid: Alianza Editorial, 1991.

. O círculo de giz caucasiano. In: Teatro Completo, vol. 9. Rio de Janeiro: Paz e Terra, 1992.

. O Círculo de giz caucasiano. São Paulo: Cosacnaify, 2002.

. Teatro Completo, vol. 8. São Paulo: Paz e Terra, 1992.

BUCCI, Eugênio. Como o capital aprendeu a falar. In: Praga, n. 3, São Paulo:

Hucitec, setembro de 1997.

BUCK-MORSS, Susan. Benjamin. In: BENJAMIN, Walter. The Work of Art in the Age of Mechanical Reproduction, Illuminations. New York: Schocken Books, 1969.

BÜRGER, Peter. O Antivanguardismo de Adorno. Tradução de Newton Ramos de Oliveira, Faculdade de Ciências e Letras da UNESP (Publicação interna). In: http://antivalor.atspace.com/Frankfurt/burger.htm. Consultado em 12/10/10.

CANETTI, Elias. Massa e poder. São Paulo: Cia. das Letras, 1999.

CHIARELLO, Maurício. Natureza-morta: finitude e negatividade em T.W. Adorno. São Paulo: Edusp, 2006.

COSTA, Iná Camargo e CARVALHO, Dorberto. A luta dos grupos teatrais de são Paulo por políticas públicas para a cultura. São Paulo: Cooperativa Paulista de Teatro, 2008 .

COSTA, Iná Camargo. A hora do teatro épico no Brasil. Rio de Janeiro: Paz e Terra, 1996.

- O Nome do jogo, prefácio in: Cia. Do Latão: 7 peças. São Paulo:

Cosacnaify, 2008.

COUTINHO, Carlos Nelson. Cultura e sociedade no Brasil. Rio de Janeiro: Oficina de Livros, 1990.

DANTO, Arthur C. Após o fim da arte. São Paulo: EDUSP, 2010.

DEBORD, Guy. A sociedade do espetáculo. Rio de janeiro, 1997.

DELEUZE, Gilles, GUATTARI, Felix. O Anti-Édipo. São Paulo: Ed. 34, 2010.

DELEUZE, Gilles. Conversações. São Paulo, Ed. 34, 1998.

DELMANTO, Ivan. Caderno de direção - 2004. Inédito, 2004.

. Caderno de direção- 2005. Inédito, 2005. 
. Caderno de direção - 2006. Inédito, 2006.

DERRIDA, Jacques. Enlouquecer o Subjétil, São Paulo: Editora Unesp, 1998.

DICKINSON, Emily. Alguns poemas. São Paulo: Iluminuras, 2006.

DORT, Bernard. Le texte et la scene: pour une nouvelle alliance. In: http://www.universalis.fr/encyclopedie/bernard-dort/. Consultado em 11/09/10.

DURÃO, Fábio. As artes em nó. Rio de Janeiro: Alea, vol. 5, n. 1., Jan/Jul 2003. In: http://www.scielo.br/scielo.php?script=sci arttext\&pid=S1517106X2003000100004\#ba ckx1. Consultado em 12/12/2010.

ECO, Umberto. A obra aberta. São Paulo: Perspectiva, 1996.

EISENSTEIN, Sergei. "Palavra e imagem ( Montazh 1938)". In: O sentido do filme. Rio de Janeiro: Jorge Zahar, 2002.

ENZENSBERGER, Hans Magnus. As aporias da Vanguara. In: Com raiva e paciência: ensaios sobre literatura, política e colonialismo. São Paulo: Paz e Terra, 1985.

FABIÃO, Eleonora. Performance e Teatro: poéticas e políticas da cena contemporânea. In: Cartografias do Ensino de Teatro (org.) Adilson Florentino e Narciso Telles, editora EDUFU (no prelo).

FÉRAL, Josette. Por uma poética da performatividade: o teatro performativo. Revista Sala Preta: São Paulo: ECA-USP, 2009.

FONTENELLE, Isleide. Fetiche do eu autônomo: consumo responsável, excesso e redenção como mercadoria. 2010. Inédito.

FOUCAULT, Michel Os Anormais. São Paulo: Martins Fontes, 2002. . História da sexualidade I - A vontade de saber. São Paulo: Graal, 1998. . Segurança, Território, População. São Paulo: Martins Fontes, 2008. . Seminário - livro 16: de um Outro ao Outro. Rio de Janeiro: Zahar, 2008. . Vigiar e Punir. Petrópolis: Ed. Vozes, 1999.

FREITAS, Aiana. Estímulo à colaboração explica sucesso da Pixar. In: O ESTADO DE SÃO PAULO, Caderno Negócios, 29 de julho de 2010, p. B14.

FREUD, Sigmund. "A negativa” . In: Ed. Standard Brasileira das Obras Psicológicas Completas, Vol. XIX. Rio de Janeiro, Imago, 1976.

G.W.F. HEGEL, Leciones de la historia de la filosofia, III. Ciudad de Mexico: Fondo de Cultura Económica, 1985.

GUATTARI, Felix. Caosmose. São Paulo: Ed. 34, 2003. 
HAUG, Wolfgang Fritz. Crítica da estética da mercadoria. São Paulo: Fundação Editora da UNESP, 1998.

HEGEL, G.W.F. Fragmento 22 dos Jenaer Sytementwürfe (1803/1804). Tradução de Erick C. Lima. In: Revista Eletrônica de Estudos Hegelianos, ano5, n.8, junho de 2008. Consultado em 1/2/2010.

HEGEL, Georg Wilhelm Friedrich. Curso de estética: o sistema das artes. São Paulo: Martins Fontes, 1997. . Enciclopédia das ciências filosóficas em compêndio: a ciência da lógica. São Paulo: Loyola, 1995.

HEIDEGGER, Martin. Ser e verdade. São Paulo: Vozes, 2007.

HOMERO. Odisséia. Lisboa: Cotovia, 2003.

JAMESON, Fredric. As marcas do visivel. Rio de Janeiro: Graal, 1995. . O inconsciente político. São Paulo: Ática, 1996. . O método Brecht. São Paulo: Vozes, 1999.

KAFKA, Franz. Contemplação e O foguista. São Paulo: Cia. das Letras, 2002.

KANT, Immanuel. A metafísica dos costumes. Bauru, SP: Edipro, 2008.

KURZ, Robert. La crise del valor de cambio. Mexico D.F.: Critica Marxista, 1986.

LACAN, Jaques. Outros Escritos. Rio de Janeiro: Zahar, 2005.

LEHMANN, Hans-Thies. O teatro pós-dramático. São Paulo: Cosac \& Naif, 2007.

LUKÁCS, Georg. A teoria do romance. São Paulo: Duas Cidades, Ed. 34, 2000. . Georg Lukács: sociologia. São Paulo: Ática, 1981. . La novela historica. Mexico, D.F.: Ediciones Era, 1966. . Estética, vol. 3. Barcelona- México D.F.: Grijalbo, 1967.

SANTOS, Maria Thais Lima. Na cena do Dr. Dapertutto. São Paulo: Perspectiva, 2010. MARX, Karl e ENGELS, Friedrich. A ideologia Alemã. São Paulo: Boitempo, 2007. MARX Karl. Sobre a questão judaica. São Paulo: Boitempo, 2010. . Manuscritos econômicos-filosóficos. São Paulo: Boitempo, 2004. . Contribuição à crítica da economia política. São Paulo: Martins Fontes, 2000. . Economic Manuscripts 1861-64: Draft Chapter 6 of Capital. In: Marx$\begin{array}{lllll}\text { Engels Collected } & \text { Works. } & \text { v. } & \text { Em }\end{array}$ 
http://www.marxists.org/archive/marx/works/1864/economic/index.htm. Consultado em $12 / 12 / 2010$.

. Los fundamentos da la critica de la economia politica, tomo 2. Madrid: Alberto Corazon, 1977.

. O 18 de brumário de Luís Bonaparte. São Paulo: Boitempo, 2011.

. O Capital, livro I, vol. 2. Rio de Janeiro: Civilização Brasileira, 1999.

. O capital. Livro I, vol. 1. São Paulo: Civ. Brasileira, 2000.

. Para a crítica da economia política. Belo Horizonte: Autêntica Editora, 2010.

MELMAN, C. Charles. O homem sem gravidade. Rio de Janeiro: Companhia de Freud, 2003.

. O homem sem gravidade. Rio de Janeiro: Companhia de Freud, 2008.

MESZÁROS, István. Para além do capital. São Paulo: Boitempo, 2002.

NIETZSCHE, Friedrich. Fragmentos Póstumos (1885-1889), Vol. IV. Madrid: Editorial Tecnos, 2007.

OEHLER, Dolf. O velho mundo desce aos infernos. São Paulo: Cia. Das Letras, 1999.

OLIVEIRA, Francisco de. Crítica à razão dualista. O ornitorrinco. São Paulo: Boitempo, 2003.

. Entrevista à Cia. do Latão. In: Vintém. São Paulo: Hedra, 1999.

PAVIS, Patrice. A encenação contemporânea. São Paulo: Perspectiva, 2010.

. O teatro no cruzamento de culturas. São Paulo: Perspectiva, 2009

PROUST, Marcel. Em busca do tempo perdido. À sombra das moças em flor. Rio de Janeiro: Ediouro, 2004

ROSENFELD, Anatol. Prismas do teatro. São Paulo: Perspectiva, 1993

SAFATLE, Vladimir. Cinismo e falência da crítica. São Paulo: Boitempo, 2008

SALECL, Renata. Sobre a felicidade: ansiedade e consumo na era do hipercapitalismo. São Paulo:Alameda situações. 2005

SCHILLER, Friedrich. Carta a Goethe de 26/12/1797. In: GOETHE, J.W. Obra completa, vol. 1. Madrid: Aguilar, 1957 . Wallenstein. Porto: Campos das Letras, 2008

SCHULZ, Bruno. Lojas de Canela. Rio de Janeiro: Imago, 1996 
SCHWARZ, Roberto. "Ainda sobre o livro de Kurz". In: Novos estudos, edição 37. CEBRAP: novembro de 1993. Versão eletrônica: http://novosestudos.uol.com.br/indice/indice.asp?idEdicao=71\#579. . Posfácio. Contribuição a John Gledson. In: GLEDSON, John. Machado de Assis: ficção e história. São Paulo: Paz e Terra, 2003 . Sequências brasileiras. São Paulo: Cia. Das Letras, 1999.

SILVA, Antônio Carlos de Araújo. A encenação em processo. In: V Congresso da Associação Brasileira de Pesquisa e Pós-Graduação em Artes Cênicas, 2010. São Paulo: Anais do VI Congresso da ABRACE - Arte e ciência: abismo de rosas. São Paulo: Anais da Abrace, 2010, vol. 1, p. 1.

SPINOZA, Benedictus de. Ética. Belo Horizonte: Autêntica Editora, 2009.

STRUGATSKY, Arkady and STRUGATSKY, Boris. Roadside Picnic. London: Penguin, 1979.

SYLVESTER, David. Sobre arte moderna. São Paulo: Cia. das Letras, 2005.

SZONDI, Peter. Ensaio sobre o trágico. Rio de Janeiro: Jorge Zahar, 2004. . Teoria do drama burguês. São Paulo: Cosac \& Naify, 2004. . Teoria do drama moderno. São Paulo: Cosac \& Naify, 2001.

VIANNA Filho, Oduvaldo. Brasil, versão brasilieira. In: PEIXOTO, Fernando. O melhor teatro do CPC da UNE. São Paulo: Global, 1989. . Os Azeredo mais os Benevides. Rio de Janeiro: MEC/SNT, 1968.

WEISS, Peter. La estética de la resistencia. Barcelona: Hiru, 2006.

WILLIAMS, Raymond. Cultura. Rio de Janeiro: Paz e Terra, 1992. . Marxismo e Literatura. Rio de Janeiro: Zahar, 1979.

ZIZEK, Slavoj, "Lacan com de Olhos bem fechados". In: Como ler Lacan. Rio de Janiero: Zahar, 2010. . A subjetividade por vir. Lisboa: Relógio d’água, 2006. . Órganos sin cuerpo. Valencia: Pre-textos, 2006. 